Pacific Northwest

National Laboratory

Operated by Battelle for the

U.S. Department of Energy

\title{
Monte Carlo Simulations for Homeland Security Using Anthropomorphic Phantoms
}

KA Burns

January 2008

Prepared for the U.S. Department of Energy

under Contract DE-AC05-76RL01830 


\title{
DISCLAIMER
}

This report was prepared as an account of work sponsored by an agency of the United States Government. Neither the United States Government nor any agency thereof, nor Battelle Memorial Institute, nor any of their employees, makes any warranty, express or implied, or assumes any legal liability or responsibility for the accuracy, completeness, or usefulness of any information, apparatus, product, or process disclosed, or represents that its use would not infringe privately owned rights. Reference herein to any specific commercial product, process, or service by trade name, trademark, manufacturer, or otherwise does not necessarily constitute or imply its endorsement, recommendation, or favoring by the United States Government or any agency thereof, or Battelle Memorial Institute. The views and opinions of authors expressed herein do not necessarily state or reflect those of the United States Government or any agency thereof.

\author{
PACIFIC NORTHWEST NATIONAL LABORATORY \\ operated by \\ BATTELLE \\ for the \\ UNITED STATES DEPARTMENT OF ENERGY \\ under Contract DE-AC05-76RL01830
}

Printed in the United States of America
Available to DOE and DOE contractors from the Office of Scientific and Technical Information,
P.O. Box 62, Oak Ridge, TN 37831-0062;
ph: (865) 576-8401
fax: $(865)$ 576-5728
email: reports@adonis.osti.gov

\begin{abstract}
Available to the public from the National Technical Information Service, U.S. Department of Commerce, 5285 Port Royal Rd., Springfield, VA 22161 ph: (800) 553-6847 fax: $(703) 605-6900$ email: orders@ntis.fedworld.gov online ordering: http://www.ntis.gov/ordering.htm
\end{abstract}

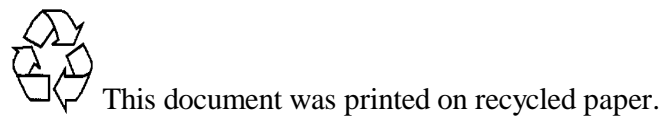




\section{MONTE CARLO SIMULATIONS FOR HOMELAND SECURITY USING ANTHROPOMORPHIC PHANTOMS}

A Thesis

Presented to

The Academic Faculty

by

Kimberly A Burns

In Partial Fulfillment

of the Requirements for the Degree

Master of Science in the

George W. Woodruff School of Mechanical Engineering

Georgia Institute of Technology

January 2008 


\section{MONTE CARLO SIMULATIONS FOR HOMELAND SECURITY USING ANTHROPOMORPHIC PHANTOMS}

Approved by:

Dr. Nolan E. Hertel, Advisor

Nuclear and Radiological Engineering

Georgia Institute of Technology

Dr. Chris Wang

Nuclear and Radiological Engineering

Georgia Institute of Technology
Dr. Keith Eckerman

Oak Ridge National Laboratory

Dr. Armin J. Ansari

Centers for Disease Control and Prevention

Date Approved: 


\section{ACKNOWLEDGEMENTS}

First I would like to thank my family. They have always believed in me and supported me. If it was not for their love and support, I would not be where I am today.

I would like to acknowledge Dr. Hertel for being a great advisor and an inspiration. He has shown me that I am capable of achieving much more than I could have ever imagined. Thank you, Dr. Hertel, for challenging me and believing in me. Additionally, I would like to thank my reading committee, Dr. Chris Wang, Dr. Keith Eckerman and Dr. Armin J. Ansari, for their time and input. I would like to acknowledge the Centers for Disease Control and Prevention Radiation Studies Branch for funding this work. I would also like to thank Ryan Manger for all of his help with DCAL and troubleshooting the phantoms and Michael Bellamy for his help with Mathematica. Finally I would like to thank Eric Burgett and Dwayne Blaylock

for helping me solve some difficult MCNP problems and keeping the Linux boxes running. I could not have accomplished all of this without everyone's help. Thank you. 


\section{TABLE OF CONTENTS}

ACKNOWLEDGEMENTS

LIST OF TABLES

LIST OF FIGURES $\quad$ xvi

SUMMARY Xviii

CHAPTER 1 INTRODUCTION 1

CHAPTER 2 METHOD

2.1 Monte Carlo Simulations 4

2.2 Dose Calculations $\quad 9$

CHAPTER 3 ANTHROPOMORPHIC PHANTOMS 14

3.1 Reference Male and Reference Female Phantoms 14

3.2 Adipose Male, Adipose Female and Postmenopausal Adipose Female Phantoms

CHAPTER 4 DOSE TO HEALTHCARE PROVIDERS 19

4.1 Externally Contaminated Patients 19

4.2 Internally Contaminated Patients 26

4.3 Comparison of Dose to Healthcare Provider Due to Internally and Externally Contaminated Patients $\quad 38$

CHAPTER 5 DOSE TO PATIENTS 41

5.1 Reference Male

5.2 Reference Female 43

5.3 Adipose Male $\quad 44$

5.4 Adipose Female $\quad 45$

5.5 Postmenopausal Adipose Female $\quad 47$ 
5.7 Beta Dose to Patient 51

CHAPTER 6 CONCLUSIONS

$\begin{array}{lll}\text { APPENDIX A Composition of Surgical Table } & 54\end{array}$

APPENDIX B Mass of Each Compartment of Phantoms 55

$\begin{array}{lll}\text { APPENDIX C Reference Male Input File } & 56\end{array}$

$\begin{array}{lll}\text { APPENDIX D Reference Female Input File } & 64\end{array}$

$\begin{array}{lll}\text { APPENDIX E Adipose Male Input File } & 72\end{array}$

$\begin{array}{llr}\text { APPENDIX F } & \text { Adipose Female Input File } & 80\end{array}$

$\begin{array}{lll}\text { APPENDIX G Postmenopausal Adipose Female Input File } & 88\end{array}$

APPENDIX H Effective Dose Contribution by Organ to Patient 97

APPENDIX I Effective Dose to Healthcare Provider Due to Externally Contaminated Patient

APPENDIX J Effective Dose to Healthcare Provider Due to Internally Contaminated Patient

$\begin{array}{ll}\text { APPENDIX K Absorbed Dose to Patient } & 126\end{array}$

APPENDIX L Absorbed Dose to Organs for Healthcare Provider Due to Externally Contaminated Patient

APPENDIX M Absorbed Dose to Organs for Healthcare Provider Due to Internally Contaminated Patient 


\section{LIST OF TABLES}

Table I Average Dose for Isotopes of 1 ALI Internal Contamination $(\mu \mathrm{Sv} / \mathrm{hr}) \quad$ xix

Table II Average Effective Dose for Isotopes for a $37 \mathrm{GBq} / \mathrm{m}^{2}$ External

Contamination $(\mathrm{mSv} / \mathrm{hr}) \quad \mathrm{xx}$

Table III Dose to Patient from $37 \mathrm{GBq} / \mathrm{m}^{2}$ External Contamination (mSv/hr) Xx

Table 1.1 Dose to Patient from Bridges' Study (mSv/hr) [1] 2

Table 1.2 Dose to Healthcare Provider from Bridges' Study (mSv/hr) [1] 2

Table 1.3 Dose to Healthcare Provider from Smith et al. [8] 2

Table 2.1 Radioisotope Energies and Intensities 3

Table 2.2 Surface Area of Skin for Anthropomorphic Phantoms 6

Table 2.3 Fractional Bone Distribution by Region $\quad 8$

Table 2.4 Bone Marrow Distribution in Body By Age 9

Table 2.5 Tissue Weighting Factors 11

Table 2.6 Number of Gammas or Betas Released per Disintegration 12

Table 2.7 Number of Becquerel per ALI for Each Isotope 12

Table 3.1 Material Densities for Anthropomorphic Phantoms [2] 14

Table 3.2 Characteristics of Adipose Phantoms 16

Table 4.1 Effective Dose for Isotopes for $37 \mathrm{GBq} / \mathrm{m}^{2}$ External Contamination (mSv/hr) 23

Table 4.2 Beta Absorbed Dose to Hands of Healthcare Provider for $37 \mathrm{GBq} / \mathrm{m}^{2}$ Externally Contaminated Patient (mGy/hr)

Table 4.3 Time in Hours Before the Healthcare Provider's Hands Receive a 3 Gy Dose for $37 \mathrm{GBq} / \mathrm{m}^{2}$ Externally Contaminated Patient

Table 4.4 Total Effective Dose to Healthcare Provider for $37 \mathrm{GBq} / \mathrm{m}^{2}$ Externally Contaminated Patient (mSv/hr)

Table 4.5 Total Effective Dose to Healthcare Provider Due to Externally Contaminated Patients $(\mathrm{mSv} / \mathrm{hr}) / \mathrm{Bq}$ 
Table 4.6 Time in Hours Before the Healthcare Provider Receives a $250 \mathrm{mSv}$ Dose for $37 \mathrm{GBq} / \mathrm{m}^{2}$ Externally Contaminated Patient

Table 4.7 Inhalation Class and Fraction of Isotope in Each Compartment Six Hours after Inhalation

Table 4.8 Effective Dose to Healthcare Provider from Patients with Internal Contamination $(\mu \mathrm{Sv} / \mathrm{hr}) / \mathrm{ALI}$

Table 4.9 Dose to Healthcare Provider from Patient for 1 ALI Internal Contamination and $37 \mathrm{GBq} / \mathrm{m}^{2}$ External Contamination for ${ }^{60} \mathrm{Co}(\mathrm{mSv} / \mathrm{hr})$

Table 4.10 Time (Hours) It Takes for Healthcare Provider to Receive $50 \mathrm{mSv}$ and 250 $\mathrm{mSv}$ Dose from $37 \mathrm{GBq} / \mathrm{m}^{2}$ Externally Contaminated Patient

Table 4.11 Comparison of Bridges' Study and the Present Work for Dose to Patient with $37 \mathrm{GBq} / \mathrm{m}^{2}$ External Contamination ( $\left.\mathrm{mSv} / \mathrm{hr}\right)[1]$

Table 4.12 Comparison of Bridges' Study, Smith et al., and the Present Work for Dose to Healthcare Provider Due to Patient with $37 \mathrm{GBq} / \mathrm{m}^{2}$ External Contamination (mSv/hr) [1] [8]

Table 5.1 Dose to Patient from $37 \mathrm{GBq} / \mathrm{m}^{2}$ Body Surface Contamination (mSv/hr)

Table 5.2 Time (Hours) Before an Individual with $37 \mathrm{GBq} / \mathrm{m}^{2}$ of External Contamination Receives $250 \mathrm{mSv}$ Dose from Gamma Dose

Table 5.3 Absorbed Dose and Contribution to Effective Dose from Betas to the Patient's Skin

Table 5.4 Effective Dose to Patient from Gammas and Betas for $37 \mathrm{GBq} / \mathrm{m}^{2}$ External Contamination $(\mathrm{mSv} / \mathrm{hr})$

Table 5.5 Time in Hours it Takes the Patient to Receive $250 \mathrm{mSv}$ Effective Dose

Table A.1 Composition of Polyurethane Foam [7]

Table A.2 Composition of Grade 304 Stainless Steel [9]

Table B.1 Mass of Compartments of Anthropomorphic Phantoms in Grams [2]

Table H.1 Effective Dose Contribution by Organ to Reference Male Patient for 37 $\mathrm{GBq} / \mathrm{m}^{2}$ Surface Contamination $(\mathrm{mSv} / \mathrm{hr})$

Table H.2 Effective Dose Contribution by Organ to Reference Female Patient for 37 $\mathrm{GBq} / \mathrm{m}^{2}$ Surface Contamination $(\mathrm{mSv} / \mathrm{hr})$

Table H.3 Effective Dose Contribution by Organ to Adipose Male Patient for 37

$\mathrm{GBq} / \mathrm{m}^{2}$ Surface Contamination $(\mathrm{mSv} / \mathrm{hr})$ 
Table H.4 Effective Dose Contribution by Organ to Adipose Female Patient for 37

$\mathrm{GBq} / \mathrm{m}^{2}$ Surface Contamination ( $\mathrm{mSv} / \mathrm{hr}$ )

Table H.5 Effective Dose Contribution by Organ to Postmenopausal Adipose Female Patient for $37 \mathrm{GBq} / \mathrm{m}^{2}$ Surface Contamination ( $\mathrm{mSv} / \mathrm{hr}$ )

Table I.1 Effective Dose Contribution by Organ to Organs from Reference Male Patient to Reference Male Healthcare Provider for $37 \mathrm{GBq} / \mathrm{m}^{2}$ of Surface Contamination $(\mathrm{mSv} / \mathrm{hr})$

Table I.2 Effective Dose Contribution by Organ to Organs from Reference Female Patient to Reference Male Healthcare Provider for $37 \mathrm{GBq} / \mathrm{m}^{2}$ of Surface Contamination $(\mathrm{mSv} / \mathrm{hr})$

Table I.3 Effective Dose Contribution by Organ to Organs from Adipose Male Patient to Reference Male Healthcare Provider for $37 \mathrm{GBq} / \mathrm{m}^{2}$ of Surface Contamination $(\mathrm{mSv} / \mathrm{hr})$

Table I.4 Effective Dose Contribution by Organ to Organs from Adipose Female Patient to Reference Male Healthcare Provider for $37 \mathrm{GBq} / \mathrm{m}^{2}$ of Surface Contamination $(\mathrm{mSv} / \mathrm{hr})$

Table I.5 Effective Dose Contribution by Organ to Organs from Postmenopausal Adipose Female Patient to Reference Male Healthcare Provider for 37 $\mathrm{GBq} / \mathrm{m}^{2}$ of Surface Contamination $(\mathrm{mSv} / \mathrm{hr})$

Table I.6 Effective Dose Contribution by Organ to Organs from Reference Male Patient to Reference Female Healthcare Provider for $37 \mathrm{GBq} / \mathrm{m}^{2}$ of Surface Contamination $(\mathrm{mSv} / \mathrm{hr})$

Table I.7 Effective Dose Contribution by Organ to Organs from Reference Female Patient to Reference Female Healthcare Provider for $37 \mathrm{GBq} / \mathrm{m}^{2}$ of Surface Contamination $(\mathrm{mSv} / \mathrm{hr})$

Table I.8 Effective Dose Contribution by Organ to Organs from Adipose Male Patient to Reference Female Healthcare Provider for $37 \mathrm{GBq} / \mathrm{m}^{2}$ of Surface Contamination $(\mathrm{mSv} / \mathrm{hr})$

Table I.9 Effective Dose Contribution by Organ to Organs from Adipose Female Patient to Reference Female Healthcare Provider for $37 \mathrm{GBq} / \mathrm{m}^{2}$ of Surface Contamination $(\mathrm{mSv} / \mathrm{hr})$

Table I.10 Effective Dose Contribution by Organ to Organs from Postmenopausal Adipose Female Patient to Reference Female Healthcare Provider for 37 $\mathrm{GBq} / \mathrm{m}^{2}$ of Surface Contamination $(\mathrm{mSv} / \mathrm{hr})$ 
Table I.11 Effective Dose Contribution by Organ to Organs from Reference Male Patient to Adipose Male Healthcare Provider for $37 \mathrm{GBq} / \mathrm{m}^{2}$ of Surface Contamination $(\mathrm{mSv} / \mathrm{hr})$

Table I.12 Effective Dose Contribution by Organ to Organs from Reference Female Patient to Adipose Male Healthcare Provider for $37 \mathrm{GBq} / \mathrm{m}^{2}$ of Surface Contamination $(\mathrm{mSv} / \mathrm{hr})$

Table I.13 Effective Dose Contribution by Organ to Organs from Adipose Male Patient to Adipose Male Healthcare Provider for $37 \mathrm{GBq} / \mathrm{m}^{2}$ of Surface Contamination $(\mathrm{mSv} / \mathrm{hr})$

Table I.14 Effective Dose Contribution by Organ to Organs from Adipose Female Patient to Adipose Male Healthcare Provider for $37 \mathrm{GBq} / \mathrm{m}^{2}$ of Surface Contamination $(\mathrm{mSv} / \mathrm{hr})$

Table I.15 Effective Dose Contribution by Organ from Postmenopausal Adipose Female Patient to Adipose Male Healthcare Provider for $37 \mathrm{GBq} / \mathrm{m}^{2}$ of Surface Contamination $(\mathrm{mSv} / \mathrm{hr})$

Table I.16 Effective Dose Contribution by Organ from Reference Male Patient to Adipose Female Healthcare Provider for $37 \mathrm{GBq} / \mathrm{m}^{2}$ of Surface Contamination $(\mathrm{mSv} / \mathrm{hr})$

Table I.17 Effective Dose Contribution by Organ from Reference Female Patient to Adipose Female Healthcare Provider for $37 \mathrm{GBq} / \mathrm{m}^{2}$ of Surface Contamination (mSv/hr)

Table I.18 Effective Dose Contribution by Organ from Adipose Male Patient to Adipose Female Healthcare Provider for $37 \mathrm{GBq} / \mathrm{m}^{2}$ of Surface Contamination $(\mathrm{mSv} / \mathrm{hr})$

Table I.19 Effective Dose Contribution by Organ from Adipose Female Patient to Adipose Female Healthcare Provider for $37 \mathrm{GBq} / \mathrm{m}^{2}$ of Surface Contamination $(\mathrm{mSv} / \mathrm{hr})$

Table I.20 Effective Dose Contribution by Organ from Postmenopausal Adipose Female Patient to Adipose Female Healthcare Provider for $37 \mathrm{GBq} / \mathrm{m}^{2}$ of Surface Contamination (mSv/hr)

Table I.21 Effective Dose Contribution by Organ from Reference Male Patient to Postmenopausal Adipose Female Healthcare Provider for $37 \mathrm{GBq} / \mathrm{m}^{2}$ of Surface Contamination $(\mathrm{mSv} / \mathrm{hr})$

Table I.22 Effective Dose Contribution by Organ from Reference Female Patient to Postmenopausal Adipose Female Healthcare Provider for $37 \mathrm{GBq} / \mathrm{m}^{2}$ of Surface Contamination $(\mathrm{mSv} / \mathrm{hr})$ 
Table I.23 Effective Dose Contribution by Organ from Adipose Male Patient to Postmenopausal Adipose Female Healthcare Provider for $37 \mathrm{GBq} / \mathrm{m}^{2}$ of Surface Contamination ( $\mathrm{mSv} / \mathrm{hr})$

Table I.24 Effective Dose Contribution by Organ from Adipose Female Patient to Postmenopausal Adipose Female Healthcare Provider for $37 \mathrm{GBq} / \mathrm{m}^{2}$ of Surface Contamination $(\mathrm{mSv} / \mathrm{hr})$

Table I.25 Effective Dose Contribution by Organ from Postmenopausal Adipose Female Patient to Postmenopausal Adipose Female Healthcare Provider for $37 \mathrm{GBq} / \mathrm{m}^{2}$ of Surface Contamination $(\mathrm{mSv} / \mathrm{hr})$

Table J.1 Effective Dose Contribution by Organ for Reference Male Healthcare Provider from the Reference Male Patient $(\mu \mathrm{Sv} / \mathrm{hr}) / \mathrm{ALI}$

Table J.2 Effective Dose Contribution by Organ for Reference Male Healthcare Provider from the Reference Female Patient $(\mu \mathrm{Sv} / \mathrm{hr}) / \mathrm{ALI}$

Table J.3 Effective Dose Contribution by Organ for Reference Male Healthcare Provider from the Adipose Male Patient $(\mu \mathrm{Sv} / \mathrm{hr}) / \mathrm{ALI}$

Table J.4 Effective Dose Contribution by Organ for Reference Male Healthcare Provider from the Adipose Female Patient $(\mu \mathrm{Sv} / \mathrm{hr}) / \mathrm{ALI}$

Table J.5 Effective Dose Contribution by Organ for Reference Male Healthcare Provider from the Postmenopausal Adipose Female Patient ( $\mu \mathrm{Sv} / \mathrm{hr}) / \mathrm{ALI}$

Table J.6 Effective Dose Contribution by Organ for Reference Male Healthcare Provider from the Reference Male Patient $(\mu \mathrm{Sv} / \mathrm{hr}) / \mathrm{ALI}$

Table J.7 Effective Dose Contribution by Organ for Reference Male Healthcare Provider from the Reference Female Patient $(\mu \mathrm{Sv} / \mathrm{hr}) / \mathrm{ALI}$

Table J.8 Effective Dose Contribution by Organ for Reference Male Healthcare Provider from the Adipose Male Patient ( $\mu \mathrm{Sv} / \mathrm{hr}) / \mathrm{ALI}$

Table J.9 Effective Dose Contribution by Organ for Reference Male Healthcare Provider from the Adipose Female Patient $(\mu \mathrm{Sv} / \mathrm{hr}) / \mathrm{ALI}$

Table J.10 Effective Dose Contribution by Organ for Reference Male Healthcare Provider from the Postmenopausal Adipose Female Patient ( $\mu \mathrm{Sv} / \mathrm{hr}) / \mathrm{ALI}$

Table J.11 Effective Dose Contribution by Organ for Reference Male Healthcare Provider from the Reference Male Patient $(\mu \mathrm{Sv} / \mathrm{hr})$ /ALI

Table J.12 Effective Dose Contribution by Organ for Reference Male Healthcare Provider from the Reference Female Patient $(\mu \mathrm{Sv} / \mathrm{hr}) /$ ALI 
Table J.13 Effective Dose Contribution by Organ for Reference Male Healthcare Provider from the Adipose Male Patient $(\mu \mathrm{Sv} / \mathrm{hr}) / \mathrm{ALI}$

Table J.14 Effective Dose Contribution by Organ for Reference Male Healthcare Provider from the Adipose Female Patient ( $\mu \mathrm{Sv} / \mathrm{hr}) / \mathrm{ALI}$

Table J.15 Effective Dose Contribution by Organ for Reference Male Healthcare Provider from the Postmenopausal Adipose Female Patient ( $\mu \mathrm{Sv} / \mathrm{hr}) / \mathrm{ALI}$

Table J.16 Effective Dose Contribution by Organ for Reference Male Healthcare Provider from the Reference Male Patient $(\mu \mathrm{Sv} / \mathrm{hr}) / \mathrm{ALI}$

Table J.17 Effective Dose Contribution by Organ for Reference Male Healthcare Provider from the Reference Female Patient $(\mu \mathrm{Sv} / \mathrm{hr}) /$ ALI

Table J.18 Effective Dose Contribution by Organ for Reference Male Healthcare Provider from the Adipose Male Patient ( $\mu \mathrm{Sv} / \mathrm{hr}) / \mathrm{ALI}$

Table J.19 Effective Dose Contribution by Organ for Reference Male Healthcare Provider from the Adipose Female Patient $(\mu \mathrm{Sv} / \mathrm{hr}) /$ ALI

Table J.20 Effective Dose Contribution by Organ for Reference Male Healthcare Provider from the Postmenopausal Adipose Female Patient ( $\mu \mathrm{Sv} / \mathrm{hr}) / \mathrm{ALI}$

Table J.21 Effective Dose Contribution by Organ for Reference Male Healthcare Provider from the Reference Male Patient $(\mu \mathrm{Sv} / \mathrm{hr}) / \mathrm{ALI}$

Table J.22 Effective Dose Contribution by Organ for Reference Male Healthcare Provider from the Reference Female Patient $(\mu \mathrm{Sv} / \mathrm{hr}) / \mathrm{ALI}$

Table J.23 Effective Dose Contribution by Organ for Reference Male Healthcare Provider from the Adipose Male Patient $(\mu \mathrm{Sv} / \mathrm{hr}) / \mathrm{ALI}$

Table J.24 Effective Dose Contribution by Organ for Reference Male Healthcare Provider from the Adipose Female Patient $(\mu \mathrm{Sv} / \mathrm{hr}) /$ ALI

Table J.25 Effective Dose Contribution by Organ for Reference Male Healthcare Provider from the Postmenopausal Adipose Female Patient $(\mu \mathrm{Sv} / \mathrm{hr}) / \mathrm{ALI}$

Table K.1 Absorbed Dose to Organs for Reference Male Patient for $37 \mathrm{GBq} / \mathrm{m}^{2}$ Surface Contamination $(\mathrm{mGy} / \mathrm{hr})$

Table K.2 Absorbed Dose to Organs for Reference Female Patient for $37 \mathrm{GBq} / \mathrm{m}^{2}$ Surface Contamination ( $\mathrm{mGy} / \mathrm{hr}$ )

Table K.3 Absorbed Dose to Organs for Adipose Male Patient for $37 \mathrm{GBq} / \mathrm{m}^{2}$ Surface Contamination $(\mathrm{mGy} / \mathrm{hr})$ 
Table K.4 Absorbed Dose to Organs for Adipose Female Patient for $37 \mathrm{GBq} / \mathrm{m}^{2}$ Surface Contamination ( $\mathrm{mGy} / \mathrm{hr}$ )

Table K.5 Absorbed Dose to Organs for Postmenopausal Adipose Female Patient for 37 $\mathrm{GBq} / \mathrm{m}^{2}$ Surface Contamination ( $\mathrm{mGy} / \mathrm{hr}$ )

Table L.1 Absorbed Dose to Organs for a Reference Male Healthcare Provider from Reference Male Patient for $37 \mathrm{GBq} / \mathrm{m}^{2}$ Surface Contamination (mGy/hr)

Table L.2 Absorbed Dose to Organs for a Reference Male Healthcare Provider from Reference Female Patient for $37 \mathrm{GBq} / \mathrm{m}^{2}$ Surface Contamination (mGy/hr)

Table L.3 Absorbed Dose to Organs for a Reference Male Healthcare Provider from Adipose Male Patient for $37 \mathrm{GBq} / \mathrm{m}^{2}$ Surface Contamination (mGy/hr)

Table L.4 Absorbed Dose to Organs for a Reference Male Healthcare Provider from Adipose Female Patient for $37 \mathrm{GBq} / \mathrm{m}^{2}$ Surface Contamination (mGy/hr)

Table L.5 Absorbed Dose to Organs for a Reference Male Healthcare Provider from Postmenopausal Adipose Female Patient for $37 \mathrm{GBq} / \mathrm{m}^{2}$ Surface Contamination ( $\mathrm{mGy} / \mathrm{hr})$

Table L.6 Absorbed Dose to Organs for a Reference Female Healthcare Provider from Reference Male Patient for $37 \mathrm{GBq} / \mathrm{m}^{2}$ Surface Contamination (mGy/hr)

Table L.7 Absorbed Dose to Organs for a Reference Female Healthcare Provider from Reference Female Patient for $37 \mathrm{GBq} / \mathrm{m}^{2}$ Surface Contamination (mGy/hr)

Table L.8 Absorbed Dose to Organs for a Reference Female Healthcare Provider from Adipose Male Patient for $37 \mathrm{GBq} / \mathrm{m}^{2}$ Surface Contamination (mGy/hr)

Table L.9 Absorbed Dose to Organs for a Reference Female Healthcare Provider from Adipose Female Patient for $37 \mathrm{GBq} / \mathrm{m}^{2}$ Surface Contamination (mGy/hr)

Table L.10 Absorbed Dose to Organs for a Reference Female Healthcare Provider from Postmenopausal Adipose Female Patient for $37 \mathrm{GBq} / \mathrm{m}^{2}$ Surface Contamination (mGy/hr)

Table L.11 Absorbed Dose to Organs for an Adipose Male Healthcare Provider from Reference Male Patient for $37 \mathrm{GBq} / \mathrm{m}^{2}$ Surface Contamination (mGy/hr)

Table L.12 Absorbed Dose to Organs for an Adipose Male Healthcare Provider from Reference Female Patient for $37 \mathrm{GBq} / \mathrm{m}^{2}$ Surface Contamination (mGy/hr)

Table L.13 Absorbed Dose to Organs for an Adipose Male Healthcare Provider from Adipose Male Patient for $37 \mathrm{GBq} / \mathrm{m}^{2}$ Surface Contamination (mGy/hr) 
Table L.14 Absorbed Dose to Organs for an Adipose Male Healthcare Provider from Adipose Female Patient for $37 \mathrm{GBq} / \mathrm{m}^{2}$ Surface Contamination (mGy/hr)

Table L.15 Absorbed Dose to Organs for an Adipose Male Healthcare Provider from Postmenopausal Adipose Female Patient for $37 \mathrm{GBq} / \mathrm{m}^{2}$ Surface Contamination $(\mathrm{mGy} / \mathrm{hr})$

Table L.16 Absorbed Dose to Organs for an Adipose Female Healthcare Provider from Reference Male Patient for $37 \mathrm{GBq} / \mathrm{m}^{2}$ Surface Contamination (mGy/hr)

Table L.17 Absorbed Dose to Organs for an Adipose Female Healthcare Provider from Reference Female Patient for $37 \mathrm{GBq} / \mathrm{m}^{2}$ Surface Contamination (mGy/hr)

Table L.18 Absorbed Dose to Organs for an Adipose Female Healthcare Provider from Adipose Male Patient for $37 \mathrm{GBq} / \mathrm{m}^{2}$ Surface Contamination (mGy/hr)

Table L.19 Absorbed Dose to Organs for an Adipose Female Healthcare Provider from Adipose Female Patient for $37 \mathrm{GBq} / \mathrm{m}^{2}$ Surface Contamination (mGy/hr)

Table L.20 Absorbed Dose to Organs for an Adipose Female Healthcare Provider from Postmenopausal Adipose Female Patient for $37 \mathrm{GBq} / \mathrm{m}^{2}$ Surface Contamination $(\mathrm{mGy} / \mathrm{hr})$

Table L.21 Absorbed Dose to Organs for a Postmenopausal Adipose Female Healthcare Provider from Reference Male Patient for $37 \mathrm{GBq} / \mathrm{m}^{2}$ Surface Contamination (mGy/hr)

Table L.22 Absorbed Dose to Organs for a Postmenopausal Adipose Female Healthcare Provider from Reference Female Patient for $37 \mathrm{GBq} / \mathrm{m}^{2}$ Surface Contamination $(\mathrm{mGy} / \mathrm{hr})$

Table L.23 Absorbed Dose to Organs for a Postmenopausal Adipose Female Healthcare Provider from Adipose Male Patient for $37 \mathrm{GBq} / \mathrm{m}^{2}$ Surface Contamination (mGy/hr)

Table L.24 Absorbed Dose to Organs for a Postmenopausal Adipose Female Healthcare Provider from Adipose Female Patient for $37 \mathrm{GBq} / \mathrm{m}^{2}$ Surface Contamination $(\mathrm{mGy} / \mathrm{hr})$

Table L.25 Absorbed Dose to Organs for a Postmenopausal Adipose Female Healthcare Provider from Postmenopausal Adipose Female Patient for $37 \mathrm{GBq} / \mathrm{m}^{2}$ Surface Contamination (mGy/hr)

Table M.1 Absorbed Dose to Organs for a Reference Male Healthcare Provider from Reference Male Patient for Internal Contamination ( $\mu \mathrm{Gy} / \mathrm{hr}) / \mathrm{ALI}$

Table M.2 Absorbed Dose to Organs for a Reference Male Healthcare Provider from Reference Female Patient for Internal Contamination ( $\mu \mathrm{Gy} / \mathrm{hr}) / \mathrm{ALI}$ 
Table M.3 Absorbed Dose to Organs for a Reference Male Healthcare Provider from Adipose Male Patient for Internal Contamination ( $\mu \mathrm{Gy} / \mathrm{hr}) / \mathrm{ALI}$

Table M.4 Absorbed Dose to Organs for a Reference Male Healthcare Provider from Adipose Female Patient for Internal Contamination ( $\mu \mathrm{Gy} / \mathrm{hr}) / \mathrm{ALI}$

Table M.5 Absorbed Dose to Organs for a Reference Male Healthcare Provider from Postmenopausal Adipose Female Patient for Internal Contamination $(\mu \mathrm{Gy} / \mathrm{hr}) / \mathrm{ALI}$

Table M.6 Absorbed Dose to Organs for a Reference Female Healthcare Provider from Reference Male Patient for Internal Contamination ( $\mu \mathrm{Gy} / \mathrm{hr}) / \mathrm{ALI}$

Table M.7 Absorbed Dose to Organs for a Reference Female Healthcare Provider from Reference Female Patient for Internal Contamination $(\mu \mathrm{Gy} / \mathrm{hr}) / \mathrm{ALI}$

Table M.8 Absorbed Dose to Organs for a Reference Female Healthcare Provider from Adipose Male Patient for Internal Contamination $(\mu \mathrm{Gy} / \mathrm{hr}) / \mathrm{ALI}$

Table M.9 Absorbed Dose to Organs for a Reference Female Healthcare Provider from Adipose Female Patient for Internal Contamination $(\mu \mathrm{Gy} / \mathrm{hr}) / \mathrm{ALI}$

Table M.10 Absorbed Dose to Organs for a Reference Female Healthcare Provider from Postmenopausal Adipose Female Patient for Internal Contamination $(\mu \mathrm{Gy} / \mathrm{hr}) / \mathrm{ALI}$

Table M.11 Absorbed Dose to Organs for a Adipose Male Healthcare Provider from Reference Male Patient for Internal Contamination ( $\mu \mathrm{Gy} / \mathrm{hr}) / \mathrm{ALI}$

Table M.12 Absorbed Dose to Organs for a Adipose Male Healthcare Provider from Reference Female Patient for Internal Contamination ( $\mu \mathrm{Gy} / \mathrm{hr}) / \mathrm{ALI}$

Table M.13 Absorbed Dose to Organs for a Adipose Male Healthcare Provider from Adipose Male Patient for Internal Contamination ( $\mu \mathrm{Gy} / \mathrm{hr}) / \mathrm{ALI}$

Table M.14 Absorbed Dose to Organs for a Adipose Male Healthcare Provider from Adipose Female Patient for Internal Contamination $(\mu \mathrm{Gy} / \mathrm{hr}) / \mathrm{ALI}$

Table M.15 Absorbed Dose to Organs for a Adipose Male Healthcare Provider from Postmenopausal Adipose Female Patient for Internal Contamination $(\mu \mathrm{Gy} / \mathrm{hr}) / \mathrm{ALI}$

Table M.16 Absorbed Dose to Organs for a Adipose Female Healthcare Provider from Reference Male Patient for Internal Contamination ( $\mu \mathrm{Gy} / \mathrm{hr}) / A L I$

Table M.17 Absorbed Dose to Organs for a Adipose Female Healthcare Provider from Reference Female Patient for Internal Contamination ( $\mu \mathrm{Gy} / \mathrm{hr}) / \mathrm{ALI}$ 
Table M.18 Absorbed Dose to Organs for a Adipose Female Healthcare Provider from Adipose Male Patient for Internal Contamination $(\mu \mathrm{Gy} / \mathrm{hr}) / \mathrm{ALI}$

Table M.19 Absorbed Dose to Organs for a Adipose Female Healthcare Provider from Adipose Female Patient for Internal Contamination $(\mu \mathrm{Gy} / \mathrm{hr}) / \mathrm{ALI}$

Table M.20 Absorbed Dose to Organs for a Adipose Female Healthcare Provider from Postmenopausal Adipose Female Patient for Internal Contamination $(\mu \mathrm{Gy} / \mathrm{hr}) / \mathrm{ALI}$

Table M.21 Absorbed Dose to Organs for a Postmenopausal Adipose Female Healthcare Provider from Reference Male Patient for Internal Contamination $(\mu \mathrm{Gy} / \mathrm{hr}) / \mathrm{ALI}$

Table M.22 Absorbed Dose to Organs for a Postmenopausal Adipose Female Healthcare Provider from Reference Female Patient for Internal Contamination $(\mu \mathrm{Gy} / \mathrm{hr}) / \mathrm{ALI}$

Table M.23 Absorbed Dose to Organs for a Postmenopausal Adipose Female Healthcare Provider from Adipose Male Patient for Internal Contamination $(\mu \mathrm{Gy} / \mathrm{hr}) / \mathrm{ALI}$

Table M.24 Absorbed Dose to Organs for a Postmenopausal Adipose Female Healthcare Provider from Adipose Female Patient for Internal Contamination $(\mu \mathrm{Gy} / \mathrm{hr}) / \mathrm{ALI}$

Table M.25 Absorbed Dose to Organs for a Postmenopausal Adipose Female Healthcare Provider from Postmenopausal Adipose Female Patient for Internal Contamination $(\mu \mathrm{Gy} / \mathrm{hr}) / \mathrm{ALI}$ 


\section{LIST OF FIGURES}

Figure 2.1 Three-Dimensional Representation of Adipose Female Healthcare Provider and Reference Male Patient

Figure 2.2 Two-Dimensional Representation of Reference Male Healthcare Provider and Reference Female Patient

Figure 3.1 Graphic of Reference Male

Figure 3.2 Graphic of Reference Female

Figure 3.3 Graphic of Adipose Male

Figure 3.4 Graphic of Adipose Female

Figure 3.5 Graphic of Postmenopausal Adipose Female

Figure 4.1 Healthcare Provider Effective Dose Due to $37 \mathrm{GBq} / \mathrm{m}^{2}$ of External Contamination of ${ }^{137} \mathrm{Cs}$ on the Patient

Figure 4.2 Effective Dose Rate Due to Healthcare Provider Due to ${ }^{60} \mathrm{Co}$ (slow)

Figure 4.3 Effective Dose Rate Due to Healthcare Provider Due to ${ }^{60} \mathrm{Co}$ (moderate)

Figure 4.4 Effective Dose Rate Due to Healthcare Provider Due to ${ }^{241} \mathrm{Am}$

Figure 4.5 Effective Dose Rate Due to Healthcare Provider Due to ${ }^{192} \operatorname{Ir}$ (slow)

Figure 4.6 Effective Dose Rate Due to Healthcare Provider Due to ${ }^{192} \operatorname{Ir}$ (moderate)

Figure 4.7 Effective Dose Rate Due to Healthcare Provider Due to ${ }^{192} \operatorname{Ir}$ (fast)

Figure 4.8 Effective Dose Rate Due to Healthcare Provider Due to ${ }^{137} \mathrm{Cs}$

Figure 4.9 Effective Dose Rate Due to Healthcare Provider Due to ${ }^{131}$ I

Figure 5.1 The Percentage of the Effective Dose Contributions by Organ for the Reference Male

Figure 5.2 The Percentage of the Effective Dose Contributions by Organ for the Reference Female

Figure 5.3 The Percentage of the Effective Dose Contributions by Organ for the Adipose Male 
Figure 5.4 The Percentage of the Effective Dose Contributions by Organ for the Adipose Female

Figure 5.5 The Percentage of the Effective Dose Contributions by Organ for the Postmenopausal Adipose Female

Figure 5.6 Effective Dose Contributions for Each Anthropomorphic Phantom from 37 $\mathrm{GBq} / \mathrm{m}^{2}$ External Contamination of ${ }^{60} \mathrm{Co}(\mathrm{mSv} / \mathrm{hr})$

Figure 5.7 Effective Dose Contributions to Organs for Each Anthropomorphic Phantom from $37 \mathrm{GBq} / \mathrm{m}^{2}$ External Contamination of ${ }^{241} \mathrm{Am}(\mathrm{mSv} / \mathrm{hr})$ 


\section{SUMMARY}

A device which releases radioactive material for the purpose of causing terror, such as a dirty bomb, is known as a radiological dispersal device (RDD). The purpose of this study is to determine the dose to healthcare providers due to both internally and externally contaminated patients and the dose to the patient due to external contamination subsequent to an RDD event.

Monte Carlo calculations were performed to simulate healthcare workers in the operating room or trauma room at a hospital. The Monte Carlo Neutral Particle transport code MCNP5 was used for the modeling. The human body was modeled using Medical Internal Radiation Dose (MIRD-V) anthropomorphic phantoms originally developed at Oak Ridge National Laboratory (ORNL) under the specifications of International Commission on Radiation Protection (ICRP) Publication 23 and later altered at Georgia Tech [17].

This study considered two possible contamination scenarios: uniform external contamination with no internal contamination and inhaled radioactive material without any external contamination. For both scenarios, the patients isotopes considered were ${ }^{60} \mathrm{Co},{ }^{137} \mathrm{Cs}$, ${ }^{131} \mathrm{I},{ }^{192} \mathrm{Ir}$, and ${ }^{241} \mathrm{Am}$. For the externally contaminated patient, a uniform volume source two millimeters thick was placed around the skin of each anthropomorphic phantom to simulate a uniform source on the surface of the body. For the internally contaminated patients, the Dose and Risk Calculation software, DCAL, was used to determine the distribution of the isotopes in the internal organs. For both of the scenarios, the healthcare provider was placed $20-\mathrm{cm}$ from the middle of the torso of the contaminated patient.

The amount of energy deposited to the tissues and organs of the healthcare provider due to the internally and externally contaminated patients and in the patient in the case of external 
contamination was determined. The effective dose rate was calculated using the masses of the tissues and organ and tissue weighting factors from ICRP Publication 60.

The effective dose rate for the healthcare provider for internally and externally contaminated patients are given in Table I and Table II after averaging over the five phantoms used in the modeling. The internal contamination level is based on one Annual Limit on Intake (ALI) and the external contamination level was taken to be $37 \mathrm{GBq} / \mathrm{m}^{2}$. The effective dose to an externally contaminated patient depending on the patient's body type is shown in Table III.

Table I Effective Dose to the Healthcare Provider for Internal Contamination of the Patient $(\mu \mathrm{Sv} / \mathrm{hr}) / \mathrm{ALI}$

\begin{tabular}{|l|r|r|r|r|r|r|r|r|}
\hline Healthcare Provider & $\begin{array}{c}{ }^{60} \mathbf{C o} \\
(\mathbf{m})\end{array}$ & $\begin{array}{c}{ }^{60} \mathbf{C o} \\
\text { (s) }\end{array}$ & $\begin{array}{c}{ }^{192} \mathbf{I r} \\
\text { (f) }\end{array}$ & $\begin{array}{c}{ }^{192} \mathbf{I r} \\
(\mathbf{m})\end{array}$ & $\begin{array}{c}{ }^{192} \mathbf{I r} \\
\text { (s) }\end{array}$ & ${ }^{241} \mathbf{A m}$ & ${ }^{137} \mathbf{C s}$ & ${ }^{131} \mathbf{I}$ \\
\hline \hline Reference Male & 0.7 & 2.1 & 1.3 & 1.6 & 4.1 & $3.24 \mathrm{E}-06$ & 1.12 & 0.38 \\
\hline Reference Female & 0.7 & 2.2 & 1.4 & 1.7 & 4.4 & $3.60 \mathrm{E}-06$ & 1.21 & 0.43 \\
\hline Adipose Male & 0.6 & 1.7 & 0.9 & 1.1 & 3.1 & $1.97 \mathrm{E}-06$ & 0.91 & 0.30 \\
\hline Adipose Female & 0.6 & 1.8 & 1.0 & 1.3 & 3.5 & $2.38 \mathrm{E}-06$ & 0.95 & 0.32 \\
\hline $\begin{array}{l}\text { Postmenopausal } \\
\text { Adipose Female }\end{array}$ & 0.6 & 1.9 & 1.0 & 1.3 & 3.4 & $2.16 \mathrm{E}-06$ & 0.97 & 0.32 \\
\hline \hline Average & 0.6 & 2.0 & 1.1 & 1.4 & 3.7 & $2.67 \mathrm{E}-06$ & 1.03 & 0.35 \\
\hline \hline Standard Deviation & 0.1 & 0.2 & 0.2 & 0.2 & 0.5 & $7.46 \mathrm{E}-07$ & 0.14 & 0.05 \\
\hline
\end{tabular}


Table II Average Effective Dose to the Healthcare Provider for a $37 \mathrm{GBq} / \mathrm{m}^{2}$ External Contamination of the Patient $(\mathrm{mSv} / \mathrm{hr})$

\begin{tabular}{|l|r|r|r|r|r|}
\hline Healthcare Provider & ${ }^{\mathbf{6 0}} \mathbf{C o}$ & ${ }^{\mathbf{1 9 2}^{\mathbf{I r}}}$ & ${ }^{\mathbf{2 4 1}} \mathbf{A m}$ & ${ }^{\mathbf{1 3 7}_{\mathbf{C}}}$ & ${ }^{\mathbf{1 3 1}_{\mathbf{I}}}$ \\
\hline \hline Reference Male & 30.2 & 12.8 & 0.4 & 7.7 & 4.7 \\
\hline Reference Female & 31.6 & 13.6 & 0.4 & 8.1 & 5.0 \\
\hline Adipose Male & 25.2 & 9.6 & 0.2 & 6.1 & 3.6 \\
\hline Adipose Female & 27.1 & 10.7 & 0.3 & 6.7 & 4.0 \\
\hline Postmenopausal Adipose Female & 29.6 & 10.9 & 0.3 & 6.9 & 4.0 \\
\hline \hline Average & 28.5 & 11.5 & 0.3 & 7.1 & 4.2 \\
\hline \hline Standard Deviation & 3.2 & 1.8 & 0.1 & 0.9 & 0.6 \\
\hline
\end{tabular}

Table III Dose to Patient from $37 \mathrm{GBq} / \mathrm{m}^{2}$ External Contamination (mSv/hr)

\begin{tabular}{|l|r|r|r|r|r|}
\hline Patient & ${ }^{\mathbf{6 0}} \mathbf{C o}$ & ${ }^{192} \mathbf{I r}$ & ${ }^{\mathbf{2 4 1}} \mathbf{A m}$ & ${ }^{\mathbf{1 3 7}} \mathbf{C s}$ & ${ }^{\mathbf{1 3 1}} \mathbf{I}$ \\
\hline \hline Reference Male & 197 & 75.5 & 2.61 & 48.6 & 28.2 \\
\hline Reference Female & 167 & 64.3 & 2.32 & 41.2 & 24 \\
\hline Adipose Male & 199 & 78.1 & 2.94 & 49.3 & 29 \\
\hline Adipose Female & 173 & 67 & 2.3 & 42.6 & 24.9 \\
\hline Postmenopausal Adipose Female & 181 & 70.3 & 2.29 & 44.3 & 26 \\
\hline \hline Average & 183.4 & 71.0 & 2.5 & 45.2 & 26.4 \\
\hline \hline Standard Deviation & 14.2 & 5.7 & 0.3 & 3.6 & 2.1 \\
\hline
\end{tabular}

The time it takes to receive the NRC dose limit for radiation workers $(50 \mathrm{mSv})$ and the EPA guidelines for lifesaving $(250 \mathrm{mSv})$ is sufficient for the stabilization of a patient with lifethreatening injuries prior to decontamination. For a patient externally contaminated with $37 \mathrm{GBq} / \mathrm{m}^{2}$ of ${ }^{60} \mathrm{Co}$, the healthcare provider receives a $250 \mathrm{mSv}$ in 8.3 hours. The externally contaminated patient would receive $1581 \mathrm{mSv}$ in 8.3 hours. 


\section{CHAPTER 1}

\section{INTRODUCTION}

A radiological dispersal device (RDD) is a device which deliberately releases radioactive material for the purpose of causing terror or harm. One example of such a device is a dirty bomb. A dirty bomb is fabricated by combining explosives and radioactive material. In the event that a dirty bomb is detonated, there may be airborne radioactive material that can be inhaled or ingested as well as settle on an individual leading to external contamination. The number of contaminated patients will depend on many factors, but contaminated individuals requiring immediate medical attention can deliver dose to healthcare professionals as well as themselves.

For the patients requiring medical attention, the healthcare industry is concerned with the dose received by healthcare providers while exposed to contaminated patients. The dose to the patient due to external contamination will first be determined. The dose to the healthcare provider, or individual spending time very close to the patient such as in the operating room, treating the externally contaminated patient will then be determined. Because an RDD allows for the possibility that radioactive material may have also been inhaled by the patient, the effective dose rate the healthcare provider receives per ALI inhaled by the patient will also be determined.

Comparisons of the results for this study, Bridges' study [1] and Smith et al. [8] to determine the accuracy of the results. Bridges' results for the dose to the patient and the dose to the healthcare provider are shown in Tables 1.1 and 1.2, respectively. The results from Smith et al. are shown in Table 1.3. 
Table 1.1 Dose to the Patient from Bridges' Study (mSv/hr) [1]

\begin{tabular}{|c|ccccc|}
\hline Patient & ${ }^{\mathbf{6 0}} \mathbf{C o}$ & ${ }^{\mathbf{1 9 2}} \mathbf{I r}$ & ${ }^{\mathbf{2 4 1}} \mathbf{A m}$ & ${ }^{\mathbf{1 3 7}} \mathbf{C s}$ & ${ }^{\mathbf{1 3 1}} \mathbf{I}$ \\
\hline \hline Reference Male & 270 & 90.9 & 2.8 & 66.9 & 41.6 \\
Reference Female & 233 & 77.9 & 2.44 & 57.4 & 35.7 \\
Adipose Male & 219 & 74 & 2.32 & 48 & 30.5 \\
\hline
\end{tabular}

Table 1.2 Dose to the Healthcare Provider from Bridges' Study (mSv/hr) [1]

\begin{tabular}{|c|ccccc|}
\hline Healthcare Provider / Patient & ${ }^{\mathbf{6 0}} \mathbf{C o}$ & ${ }^{\mathbf{1 9 2}} \mathbf{I r}$ & ${ }^{\mathbf{2 4 1}} \mathbf{A m}$ & ${ }^{\mathbf{1 3 7}} \mathbf{C s}$ & ${ }^{\mathbf{1 3 1}} \mathbf{I}$ \\
\hline \hline Reference Male / Reference Male & 41.9 & 15.3 & 0.49 & 10.7 & 6.99 \\
Reference Female / Reference Female & 37 & 13.4 & 0.426 & 9.44 & 6.08 \\
Adipose Male / Adipose Male & 28.2 & 9.32 & 0.275 & 7.04 & 5.03 \\
Reference Male / Adipose Male & 44.2 & 16.2 & 0.529 & 11.4 & 7.42 \\
\hline
\end{tabular}

Table 1.3 Dose to the Healthcare Provider from Smith et al. (mSv/hr) [8]

\begin{tabular}{|ccccc|}
\hline${ }^{\mathbf{6 0}} \mathbf{C o}$ & ${ }^{\mathbf{1 9 2} \mathbf{I r}}$ & ${ }^{\mathbf{2 4 1}} \mathbf{A m}$ & ${ }^{\mathbf{1 3 7}} \mathbf{C s}$ & ${ }^{\mathbf{1 3 1}} \mathbf{I}$ \\
\hline \hline 39 & 15 & 0.66 & 10 & -- \\
\hline
\end{tabular}




\section{CHAPTER 2}

\section{METHODS}

There are many variables contributing to the dose received by a healthcare provider after an RDD. The level of contamination of the patient, for both internal and external contamination, is the major factor. The dose to healthcare providers is dependent on the type of contamination, whether internal or external. The body type of both the patient and the healthcare provider are also contributing factors. For external contamination, the surface area of the patient increases the total amount of radioactive material present. For internal contamination, the distribution in the body can affect the dose to the healthcare provider.

Six isotopes were considered for possible use in an RDD: ${ }^{60} \mathrm{Co},{ }^{192} \mathrm{Ir},{ }^{241} \mathrm{Am},{ }^{137} \mathrm{Cs}$, and

${ }^{131}$ I. The principal gamma-ray and average beta energies in addition to their corresponding intensities for each of the aforementioned isotopes are shown in Table 2.1.

Table 2.1 Radioisotope Energies and Intensities

\begin{tabular}{|c|c|c|c|c|c|}
\hline & ${ }^{\mathbf{6 0}} \mathbf{C o}$ & ${ }^{\mathbf{1 3 7}} \mathbf{C s}$ & ${ }^{\mathbf{1 3 1}} \mathbf{I}$ & ${ }^{\mathbf{1 9 2}} \mathbf{I r}$ & ${ }^{\mathbf{2 4 1}} \mathbf{A m}$ \\
\hline \hline $\boldsymbol{\gamma}$-ray Energy (keV) & $\begin{array}{c}1173, \\
1333\end{array}$ & 662 & $364.5,637$ & $296-612$ & 59.5 \\
\hline $\boldsymbol{\gamma}$-ray Intensity & 1,1 & 0.851 & $0.812,0.073$ & 2.13 & 0.359 \\
\hline $\begin{array}{c}\text { Average } \boldsymbol{\beta} \text { Energy } \\
(\mathbf{k V V})\end{array}$ & 96 & 173,425 & $192,97,69$ & $209,161,71$ & --- \\
\hline $\boldsymbol{\beta}$ Intensity & 0.999 & $\begin{array}{c}0.946, \\
0.054\end{array}$ & $\begin{array}{c}0.894,0.074, \\
0.021\end{array}$ & $\begin{array}{c}0.415,0.481, \\
0.056\end{array}$ & --- \\
\hline
\end{tabular}




\subsection{Monte Carlo Simulations}

The Monte Carlo simulations are carried out using Monte Carlo Neutral Particle transport code version 5 (MCNP5) [11]. MCNP is a stochastic stimulation code, and is used to model human anthropomorphic phantoms [11]. Five anthropomorphic phantoms are employed for this study: a reference male, a reference female, an adipose male, an adipose female, and a postmenopausal adipose female. The phantoms originally are all based on ICRP 23 Reference Man Publication and MIRD-V phantoms [2]. The source of the MCNP representations used as a starting point were developed at PNNL in the 1990's and have been altered at Georgia Tech.

The setup for the trauma room is the same for all simulations. The surface of the healthcare provider is positioned $20-\mathrm{cm}$ away from the midsection of the patient. The midsection of the patient was chosen instead of the head or feet due to the solid angle of the source the healthcare provider will see, providing a conservative estimate of the dose to the healthcare provider [1]. The patient is placed at the midsection of the healthcare provider laying flat on their back on top of an operating table. The operating table, which is based on a suture table at Georgia Tech Health Center, is 198.12-cm long and 68.58-cm wide. The top layer of the operating table is composed of a 7.62-cm thick piece of polyurethane foam on top of a 12-gage thick sheet of stainless steel. The composition of the polyurethane foam [7] and stainless steel 304 [9] are shown in Tables A.1 and A.2, respectively. A three-dimensional and a twodimensional representation of the setup are shown in Figures 2.1 and 2.2, respectively. 


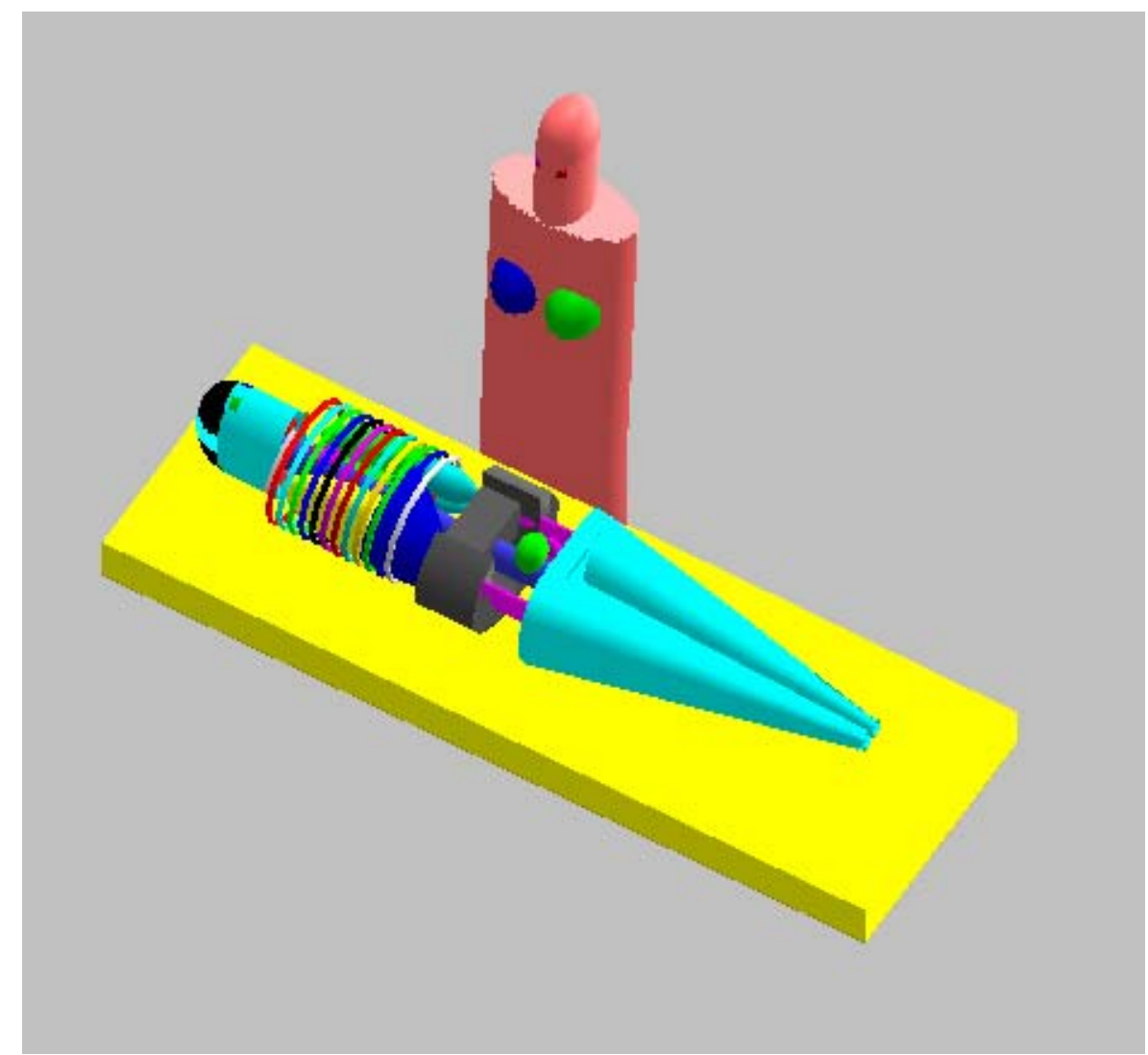

Figure 2.1 Three-Dimensional Representation of Adipose Female Healthcare Provider and Reference Male Patient.

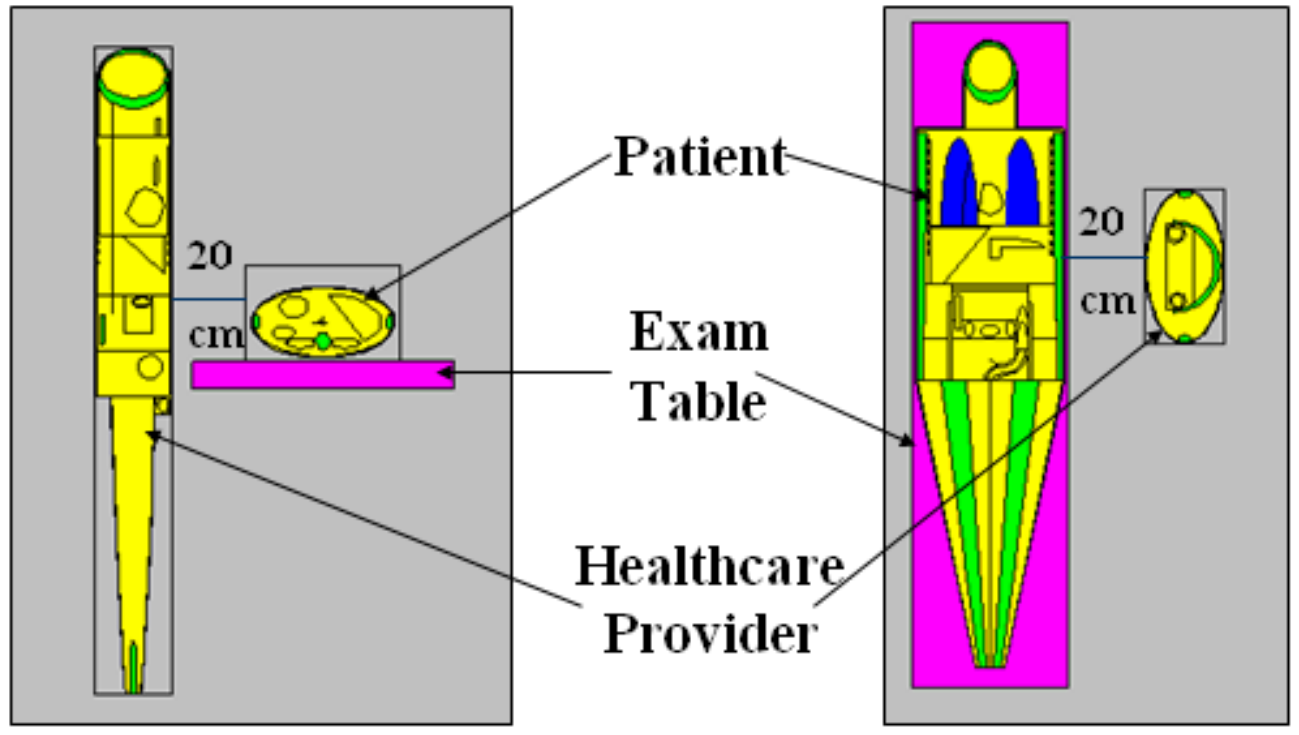

Figure 2.2 Two-Dimensional Representation of Reference Male Healthcare Provider and Reference Female Victim 
Two separate sets of simulations were performed for each phantom and each isotope: one for externally contaminated patients and the other for internally contaminated patients. In order to simulate the external contamination on the anthropomorphic phantoms, a uniform volume source was created in a 2-mm thick cell adjacent to the skin layer. A model of each phantom was created for each of the sources. According to explosives tests conducted at Sandi National Laboratories Explosives Test Center, a patient that could survive the explosion of a dirty bomb could have a maximum contamination level ranging from $3.7 \mathrm{GBq} / \mathrm{m}^{2}$ to $37.0 \mathrm{GBq} / \mathrm{m}^{2}(10$ $100 \mu \mathrm{Ci} / \mathrm{cm}^{2}$ ) [8]. A uniform contamination level of $37.0 \mathrm{GBq} / \mathrm{m}^{2}$ will be considered in this study since any other uniform contamination level only requires scaling of the dose rate. In order to determine the total source strength of the patient, the surface area of the skin for each anthropomorphic phantom is needed and is given in Table 2.2. The surface area of the reference male and reference female were obtained from ICRP Publication 23 [2]. Since the thickness of the skin was constant for all phantoms, the surface area of the adipose phantoms was determined by taking the ratio of the volume of the adipose phantom to the reference phantom and multiplying it by the surface area of the reference phantom. The externally contaminated anthropomorphic phantoms were used to determine the dose to the patient and the dose to the healthcare provider.

Table 2.2 Surface Area of Skin for Anthropomorphic Phantoms

\begin{tabular}{|l|c|}
\hline Phantom & Surface Area \\
\hline \hline Reference Male & $1.800 \mathrm{~m}^{2}$ \\
Reference Female & $1.635 \mathrm{~m}^{2}$ \\
Adipose Male & $2.520 \mathrm{~m}^{2}$ \\
Adipose Female & $2.013 \mathrm{~m}^{2}$ \\
Postmenopausal Adipose Female & $2.148 \mathrm{~m}^{2}$ \\
\hline
\end{tabular}


The second set of simulations was completed using internally contaminated phantoms as the patients. In order to determine where to properly distribute each isotope inside the phantom, the DCAL program [12] was used to track the movement of radionuclides through the body after inhalation as a function of time. DCAL requires the inhalation class of the isotope to determine the appropriate percentage of the amount of radioactive material initially inhaled to be deposited in each compartment of the body. The inhalation class is determined according to the rate of clearance of the material from the pulmonary region of the lungs. The inhalation class for each of the isotopes was determined using Rad Toolbox [13]. For the simulations presented herein, the isotope distributions in the patients were determined for a post-inhalation time of six hours.

Further compartmentalization of the output from DCAL for some of the larger organs including the blood, bone surface, bone volume, red bone marrow, body tissue, upper large intestine, lower large intestine and "other" needed to be performed before the source definitions could be completed. According to ICRP 23, $10 \%$ of the blood is located in the heart [2]. Since the heart was not one of the main organs listed in the DCAL output, this fraction of the radioactive material in the blood was placed in the heart. The remaining $90 \%$ of the radioactive material in the blood was added to the contents in the body tissue and "other" categories. It was assumed that the DCAL output for organs, such as the liver which contains a large amount of blood but were already included as a separate organ in the DCAL output, contained the total radiation present in that organs, so no additional radioactive material was added to these organs. This total was distributed to the different cells containing body tissue on a fractional weight basis.

The bone categories were distributed differently. The distribution of bone and bone marrow in the body were obtained from ICRP 23 and is shown in Tables 2.3 and 2.4, 
respectively [2]. The isotope in the bone surface and the bone volume categories were summed. The fraction of radioactive material present in each of the phantom skeletal regions was determined from the DCAL output using the distributions. The sum of the contribution due to the bone and the bone marrow were added to each of the phantom skeletal regions. Additionally the upper large intestine was split into the ascending and transverse colon, and the lower large intestine was split into the sigmoid and descending colon using the fractional weight of each compartment according to ICRP 23 [2]. All of the simplified compartmentalized fractions from DCAL were then used to create the sources within the anthropomorphic phantoms. The internal contamination of the patients were completed by making individual sources in each internal compartment and entering the fraction of the radioactive material present after six hours for each of the isotopes and each of the phantoms.

Table 2.3 Fractional Bone Distribution by Region

\begin{tabular}{|l|r|}
\hline Phantom Skeletal Region & Fraction \\
\hline \hline Legs & 0.3568 \\
Arms & 0.1592 \\
Spine & 0.1098 \\
Pelvis & 0.0784 \\
Skull & 0.1412 \\
Ribs & 0.1530 \\
\hline
\end{tabular}


Table 2.4 Bone Marrow Distribution in Body by Age

\begin{tabular}{|l|c|c|}
\hline Phantom Skeletal Region & 10-Year-Old Androgynous Child & Adult \\
\hline \hline Skull & 0.1272 & 0.0832 \\
Scapulae & 0.0289 & 0.0285 \\
Clavicles & 0.0089 & 0.0079 \\
Ribs & 0.1302 & 0.1922 \\
Spine (upper) & 0.227 & 0.2986 \\
Pelvis & 0.2873 & 0.3332 \\
Legs & 0.1637 & 0.0335 \\
Arms & 0.0268 & 0.0229 \\
\hline
\end{tabular}

\subsection{Dose Calculations}

The dose calculation is completed in accordance with ICRP 60 [3]. A tally of the energy deposited in the cell (*F8 tally in MCNP parlance) was used to determine amount of energy in $\mathrm{MeV}$ per source particle deposited in each compartment of the body. A tally of only the photon energy was taken since the *F8 tally for photons, for electrons, and for photons and electrons are equivalent in MCNP. MCNP tallies both electron and photons if present, even if only requested to tally one or the other [11]. The mass of each compartment was obtained from ICRP 23 and are shown in Appendix B. To compute the effective dose, it is necessary to tally over each organ independently. The tissue weighting factors obtained from ICRP 60 [3] are used to create a weighted sum of these organ doses. They are shown in Table 2.5 and account for the different radiosensitivities of different compartments of the human body. The energy-deposition tally for each organ were divided by the mass of that organ then multiplied by the appropriate tissue weighting factor. Due to the inability to split the tally of the bone into bone surface and red bone marrow, the tally for the bone was split into two sections based on the fraction of the total bone mass that makes up the bone surface and the red bone marrow. The weighting factors for these 
components were then applied to these sections. The tallies for the colon wall were broken into four components: ascending colon, transverse colon, sigmoid colon and descending colon. These sections were divided by the mass of the wall of each section prior to being summed and multiplied by the tissue weighting factor. The remainder is composed of muscle, uterus, brain, heart, small intestines, kidneys, spleen, pancreas, thymus, and the adrenal glands. The dose to the remainder is determined in the same fashion as that used for determining the dose to the colon wall. To obtain the effective dose rate per source particle, the sum of the dose rate to the individual organs was summed as shown by Equations 2.1 and 2.2.

$$
\begin{gathered}
E=\sum_{T} H_{T} \\
H_{T}=\sum_{R} w_{R} D_{T, R}
\end{gathered}
$$

Where:

$$
\begin{aligned}
& H_{T} \quad=\text { equivalent organ dose }(\mathrm{Sv}) \\
& w_{R} \quad=\text { radiation weighting factor } \\
& D_{T, R} \quad=\text { absorbed dose averaged over the tissue or organ } \mathrm{T} \text {, due to radiation } \mathrm{R}(\mathrm{Gy})
\end{aligned}
$$


Table 2.5 Tissue Weighting Factors [3]

\begin{tabular}{|c|c|}
\hline Organ & Tissue Weighting Factor \\
\hline \hline Gonads & 0.2 \\
\hline Stomach & 0.12 \\
\hline Colon & 0.12 \\
\hline Bladder & 0.05 \\
\hline Lungs & 0.12 \\
\hline Bone & 0.13 \\
\hline Liver & 0.05 \\
\hline Thyroid & 0.05 \\
\hline Esophagus & 0.05 \\
\hline Skin & 0.01 \\
\hline Other & 0.05 \\
\hline Breast & 0.05 \\
\hline
\end{tabular}

For the internal contamination of the patient, obtaining the effective dose rate to the healthcare professional per ALI inhaled by the patient is the quantity of interest. The annual limit on intake or ALI is defined as the amount of intake of a specific radionuclide resulting in the reference male receiving a committed effective dose equivalent of 0.05 Sievert or a committed dose equivalent of 0.5 Sievert to any organ or tissue [10]. The ALI for each isotope was determined using the ICRP 72 public inhalation dose coefficients [20]. The previously determined effective dose rate per source particle per organ is multiplied by the number of gammas or betas released per disintegration and the number of Becquerel per ALI. These values are shown in Tables 2.6 and Table 2.7, respectively. The effective dose equivalent per ALI will allow the healthcare industry to determine the dose to a healthcare provider as a function of intake by a patient. 
Table 2.6 Number of Gammas or Betas Released per Disintegrations

\begin{tabular}{|c|c|}
\hline Isotope & Gammas/Betas Per Disintegration \\
\hline \hline${ }^{241} \mathrm{Am}$ & 0.9708 \\
\hline${ }^{137} \mathrm{Cs}$ & 0.9585 \\
\hline${ }^{60} \mathrm{Co}$ & 2 \\
\hline${ }^{192} \mathrm{Ir}$ & 2.13 \\
\hline${ }^{131} \mathrm{I}$ & 1 \\
\hline
\end{tabular}

Table 2.7 Number of Becquerel per ALI for Each Isotope

\begin{tabular}{|c|c|}
\hline Isotope & Bq/ALI \\
\hline \hline${ }^{241} \mathrm{Am}$ & $1.19 \mathrm{E}+03$ \\
\hline${ }^{137} \mathrm{Cs}$ & $1.09 \mathrm{E}+07$ \\
\hline${ }^{60} \mathrm{Co}$ (slow) & $1.61 \mathrm{E}+06$ \\
\hline${ }^{60} \mathrm{Co}$ (moderate) & $5.00 \mathrm{E}+06$ \\
\hline${ }^{192} \mathrm{Ir}$ (slow) & $7.57 \mathrm{E}+06$ \\
\hline${ }^{192} \mathrm{Ir}$ (moderate) & $9.61 \mathrm{E}+06$ \\
\hline${ }^{192} \mathrm{Ir}$ (fast) & $2.78 \mathrm{E}+07$ \\
\hline${ }^{131} \mathrm{I}$ & $6.76 \mathrm{E}+06$ \\
\hline
\end{tabular}

The dose from an externally contaminated patient to themselves and to the healthcare provider is determined in a slightly different manner. A uniform volume source was placed over the entire skin layer of the phantom. Using the information available from the explosive testing conducted at Sandi National Laboratories Explosive Test Center, potential contamination levels ranging from 3.7 to $37 \mathrm{GBq} / \mathrm{m}^{2}$ may be expected for patients sustaining life-threatening injuries after an RDD [8]. In order to obtain a conservative estimate, $37 \mathrm{GBq} / \mathrm{m}^{2}$ was used. Any other contamination level can be determined by scaling the results of the study. This level was multiplied by the dose rate per source particle, the surface area of the phantoms, and the number 
of photons or betas emitted per disintegration to determine the effective dose rate to both the patient and the healthcare provider. 


\section{CHAPTER 3}

\section{ANTHROPOMORPHIC PHANTOMS}

Six different anthropomorphic phantoms were used for this study: reference male, reference female, adipose male, adipose female, post-menopausal adipose female, and a tenyear-old androgynous child. Depending on the end use of the phantoms, additional features were added to the models. All of the adult phantoms were employed in both the trauma room scenario.

\subsection{Reference Male and Reference Female Phantoms}

The reference male and reference female MCNP models were originally developed at Pacific Northwest National Laboratory (PNNL) from the MIRD representation and the ICRP 23 descriptions [14]. The reference male, shown in Figure 3.1, weighs $71.7 \mathrm{~kg}$, is $170-\mathrm{cm}$ tall and has a Body Mass Index (BMI) of 20. The BMI is determined by dividing the weight in kilograms by the square of the height in meters. The reference female, shown in Figure 3.2, is 164-cm tall, weighs $58.9 \mathrm{~kg}$ and has a BMI of 23. The material densities used for the phantoms are in Table 3.1.

Table 3.1 Material Densities for Anthropomorphic Phantoms $\left(\mathrm{g} / \mathrm{cm}^{3}\right)$ [2]

\begin{tabular}{|c|c|}
\hline Adult Tissue & 1.04 \\
\hline Skeleton & 1.4 \\
\hline Lung & 0.29 \\
\hline Air & 0.001293 \\
\hline
\end{tabular}




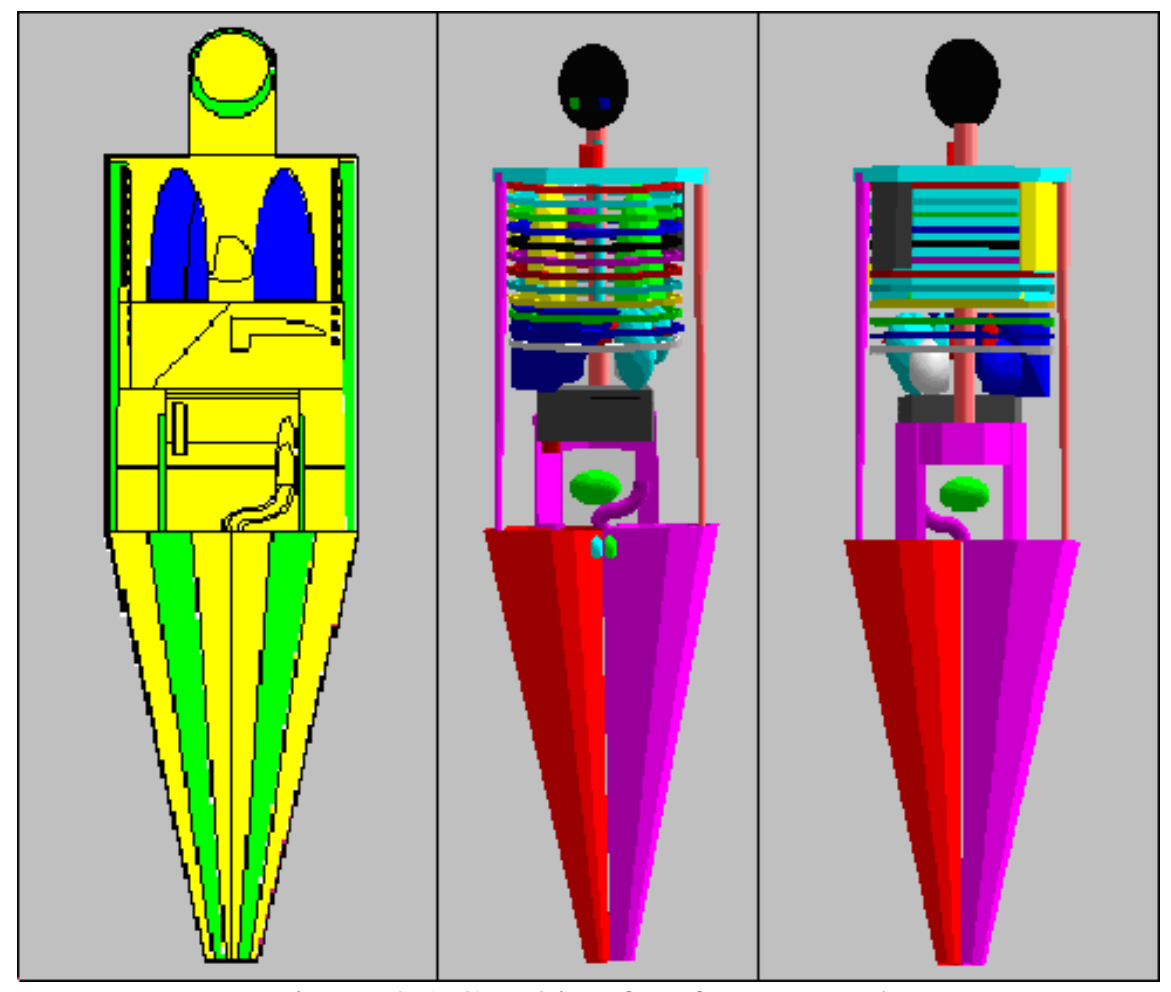

Figure 3.1 Graphic of Reference Male

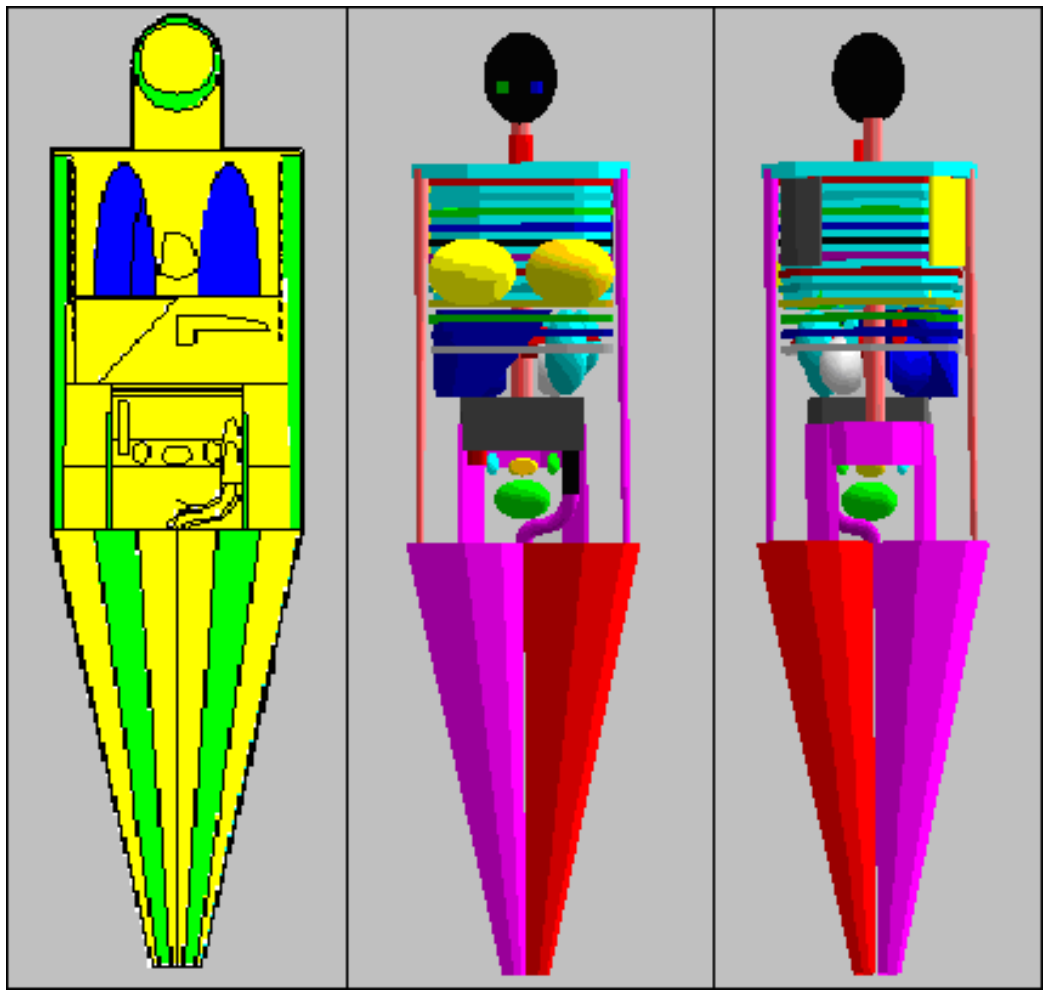

Figure 3.2 Graphic of Reference Female 
The PNNL MCNP models did not contain skin, so the addition of a skin layer was necessary. Previously an esophagus and colon walls were added to these phantoms at Georgia Tech by Simpkins and Hertel [6]. Using ICRP 23, it was determined that the average thickness human skin was approximately 2-mm [2]. Thus, a 2-mm thick skin layer was added to the outside of the phantom. An additional 2-mm thick layer was added to the outside of the skin so that a uniform volume source could be added to the outside of each phantom in order to approximate a surface source due to external contamination. The input files for the reference male and reference female phantoms can be found in Appendix C and D, respectively.

\subsection{Adipose Male, Adipose Female and Post-Menopausal Adipose Female Phantoms}

The adipose male, adipose female and post-menopausal adipose female phantoms were developed by Simpkins and Hertel [6]. The adipose phantoms were obtained by modifying the MCNP reference phantom models developed at PNNL to contain adipose tissue as explained in Table 3.2 [6]. Figures 3.3 through 3.5 depict the adipose male, adipose female and postmenopausal adipose female, respectively.

Table 3.2 Characteristics of Adipose Phantoms

\begin{tabular}{|c|c|c|c|}
\hline & Adipose Male & $\begin{array}{c}\text { Adipose } \\
\text { Female }\end{array}$ & $\begin{array}{c}\text { Post-Menopausal } \\
\text { Adipose Female }\end{array}$ \\
\hline Total Weight & $93.7 \mathrm{~kg}$ & $73.9 \mathrm{~kg}$ & $85.9 \mathrm{~kg}$ \\
\hline Adipose Weight & $22 \mathrm{~kg}$ & $15 \mathrm{~kg}$ & $27 \mathrm{~kg}$ \\
\hline BMI & 30 & 26 & 30 \\
\hline
\end{tabular}




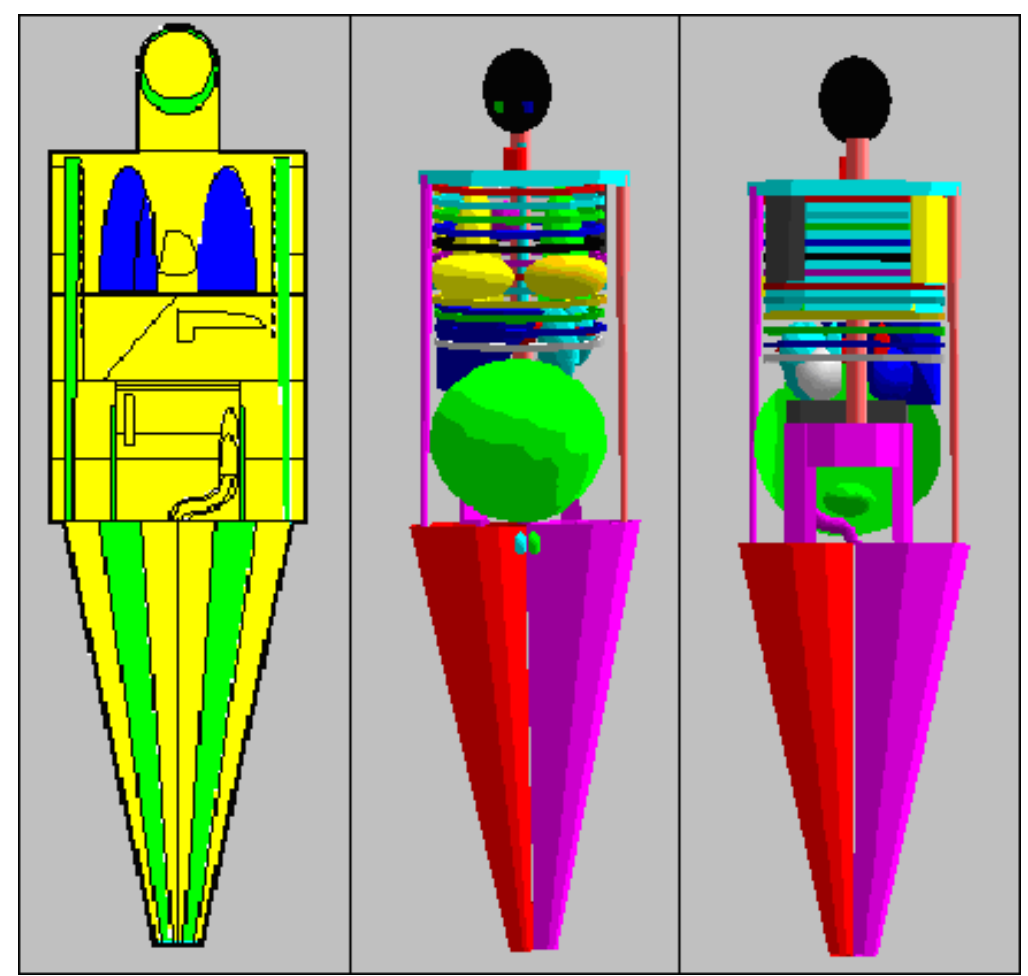

Figure 3.3 Graphic of Adipose Male

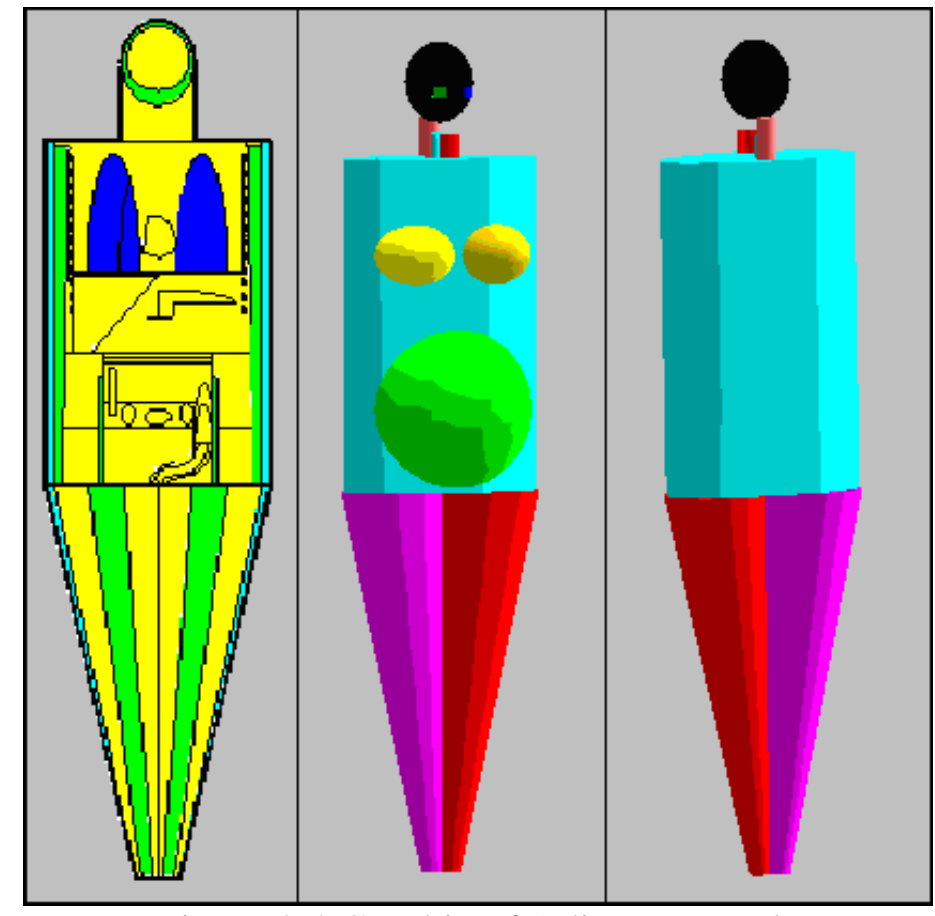

Figure 3.4 Graphic of Adipose Female 


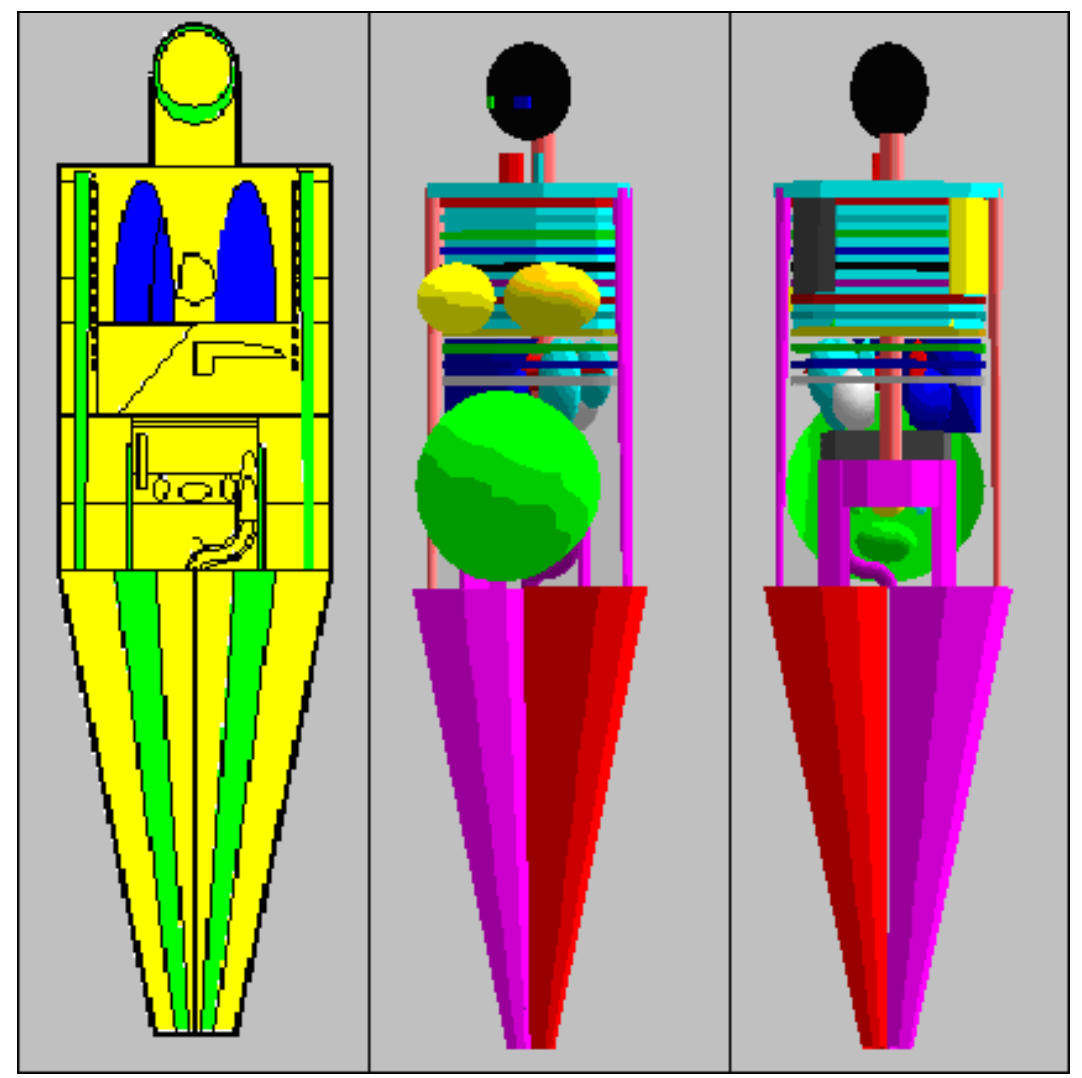

Figure 3.5 Graphic of Postmenopausal Adipose Female

For the purpose of this study, a layer of skin was added to the adipose phantoms in a similar fashion as the reference phantoms. ICRP 23 does not contain different skin thickness values for reference versus adipose phantoms, so it was assumed that the skin thickness for the adipose phantoms was approximately the same as that for the reference phantoms. The additional 2-mm thick cell was also added to the adipose phantoms for the same purpose as that for the reference phantoms. The input files for the adipose male, adipose female and postmenopausal adipose female phantoms can be found in Appendix E, F and G, respectively. 


\section{CHAPTER 4}

\section{DOSE TO HEALTHCARE PROVIDER}

The effective dose rate to the healthcare provider is of concern to the healthcare industry because it helps determine the amount of time a healthcare provider can be in contact with the patients. There are two main scenarios of concern: patients that are externally contaminated and cannot be decontaminated prior to treatment and the patients that are internally contaminated. The effects of body type of both the patient and the healthcare provider for the isotopes of concern will be considered.

According to the NRC, the annual dose limit for a radiation worker is $50 \mathrm{mSv} / \mathrm{yr}$ [16]. The National Council on Radiation Protection and Measurements allow for a one-time, whole body effective dose of up to $250 \mathrm{mSv}$ for voluntary emergency life-saving activities [5]. These limits will be used to show the amount of time a healthcare provider can treat both internally and externally contaminated patients before receiving the predetermined doses.

\subsection{Externally Contaminated Patients}

Externally contaminated patients are generally believed to pose a higher threat to the healthcare provider than internally contaminated patients because the bodies of the internally contaminated patients offer some shielding to the healthcare provider. In addition to the distance between the healthcare provider and the time the healthcare provider spends with the patient, the dose to the healthcare provider due to an externally contaminated patient is principally dependent 
on three factors: the isotope, the skin surface area of the patient, and the body type of the healthcare provider.

Energy deposition tallies were taken over each of the internal organs in the healthcare provider in order to determine the effective dose to the healthcare provider. The contribution to the effective dose rates to each organ are shown for each healthcare provider, each patient, and each isotope in Appendix I There are distinct patterns for which organ receives the highest and lowest contributions to the effective dose. For the reference male, adipose male and reference female the highest contribution to the effective dose is to either the stomach or the colon regardless of the body type of the patient. The reference phantoms have the lowest percentage of body fat and the organs in the abdominal area are closest in proximity to the patient allowing more radiation to reach the internal organs such as the colon and the stomach. For the male healthcare providers the operating table provides shielding for the gonads, greatly reducing the amount of radiation reaching this organ. The closest radiosensitive organs to the patient for the adipose male healthcare provider are also the colon and the stomach. For the adipose female phantoms, the organs that receive the highest contribution to the effective dose rate are dependent on the isotope in question. Due to the penetrating ability of ${ }^{60} \mathrm{Co},{ }^{192} \mathrm{Ir},{ }^{137} \mathrm{Cs}$ and ${ }^{131} \mathrm{I}$, either the stomach or the colon receives the highest contribution to the effective dose. For the low energy gamma emitted by ${ }^{241} \mathrm{Am}$, the breasts receive the highest contribution to the effective dose. The breasts on the adipose females are significantly larger than those on the reference female and the internal organs of the adipose females are shielded by the additional tissue, accounting for the difference between the reference female and the adipose female healthcare providers. 
The lowest contribution to the effective dose exhibits a pattern that is completely independent of both the body type of the patient and the healthcare provider. For ${ }^{60} \mathrm{Co},{ }^{192} \mathrm{Ir}$, ${ }^{137} \mathrm{Cs}$ and ${ }^{131} \mathrm{I}$, the skin produces the lowest contribution to the effective dose due to the ability of the more penetrating radiation easily reaches the internal organs and the skin's small tissue weighting factor. For ${ }^{241} \mathrm{Am}$, the radiation does not easily penetrate the body. Due to the low tissue weighting factor and the small mass of the esophagus, it receives the lowest contribution to the effective dose for the less penetrating radiation.

The overall effective dose rate as a function of body type follows a general pattern as well. A three dimensional graph of the effective dose rate as a function of the body type of the healthcare provider and the body type of the patient for $37 \mathrm{GBq} / \mathrm{m}^{2}$ external contamination with ${ }^{137} \mathrm{Cs}$ is shown in Figure 4.1. The reference female and reference male healthcare providers receive the two highest effective dose rates. The adipose tissue of the anthropomorphic phantoms cause the postmenopausal adipose female, the adipose female and the adipose male healthcare providers to receive lower effective dose rates. The adipose females receive higher dose rates than the adipose male due to the sensitivity of the breast tissue to radiation. The body type of the healthcare provider has a profound impact on the effective dose rate to the healthcare provider. 


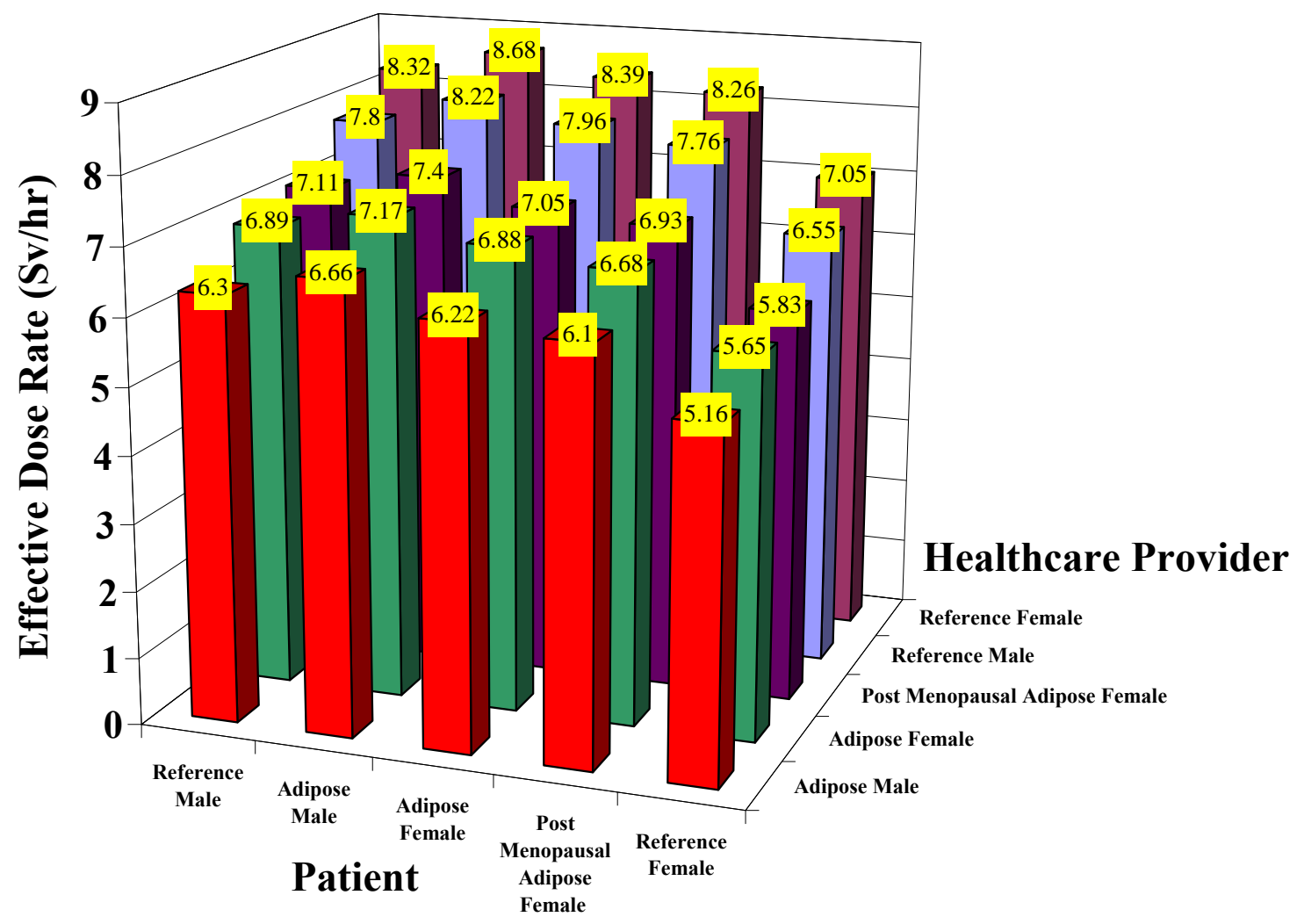

Figure 4.1 Healthcare Provider Effective Dose Due to $37 \mathrm{GBq} / \mathrm{m}^{2}$ of External Contamination of ${ }^{137} \mathrm{Cs}$ on the Patient

The effect of the body type of the patient is somewhat more complicated than the effect of the body type of the healthcare provider. The adipose male, which has the largest surface area, and the reference female, which has the smallest surface area, cause the highest and lowest effective dose rates to the healthcare providers, respectively. The other patients produced similar effective dose rates to the healthcare provider. The amount of contamination present on the patient, which is determined by the surface area of the patient, is the main factor in determining the effective dose rate to the healthcare provider based on the body type of the patient.

The isotope the patient is contaminated with plays a major role in determining the effective dose rate to the healthcare provider. The effective dose rates for different healthcare 
providers, the average effective dose rate and the standard deviation for the different isotopes at a contamination level of $37 \mathrm{GBq} / \mathrm{m}^{2}$ is shown in Table 4.1. The highest effective dose rates are due to ${ }^{60} \mathrm{Co}$ because it emits two high energy gamma rays. The lowest effective dose rate is due to ${ }^{241} \mathrm{Am}$ because it emits a low energy gamma ray. The effective dose rates due to the other isotopes are dependent on a combination on gamma-ray energy and emission intensity.

Table 4.1 Effective Dose for Isotopes for $37 \mathrm{GBq} / \mathrm{m}^{2}$ External Contamination (mSv/hr)

\begin{tabular}{|c|c|c|c|c|c|}
\hline Healthcare Provider & ${ }^{\mathbf{6 0}} \mathbf{C o}$ & ${ }^{\mathbf{1 9 2}} \mathbf{I r}$ & ${ }^{\mathbf{2 4 1}} \mathbf{A m}$ & ${ }^{137} \mathbf{C s}$ & ${ }^{\mathbf{1 3 1}} \mathbf{I}$ \\
\hline \hline \multirow{2}{*}{ Reference Male } & $30.2 \pm$ & $12.8 \pm$ & $0.4 \pm$ & $7.7 \pm$ & $4.7 \pm$ \\
& 2.69 & 1.02 & 0.03 & 0.65 & 0.39 \\
\hline \multirow{2}{*}{ Reference Female } & $31.6 \pm$ & $13.6 \pm$ & $0.4 \pm$ & $8.1 \pm$ & $5.0 \pm$ \\
& 2.58 & 1.06 & 0.03 & 0.63 & 0.39 \\
\hline \multirow{2}{*}{ Adipose Male } & $25.2 \pm$ & $9.6 \pm$ & $0.4 \pm$ & $6.1 \pm$ & $3.6 \pm$ \\
& 2.37 & 0.91 & 0.03 & 0.56 & 0.33 \\
\hline \multirow{2}{*}{ Adipose Female } & $27.1 \pm$ & $10.7 \pm$ & $0.3 \pm$ & $6.7 \pm$ & $4.0 \pm$ \\
& 2.50 & 0.91 & 0.02 & 0.59 & 0.34 \\
\hline Postmenopausal & $28.6 \pm$ & $10.9 \pm$ & $0.3 \pm$ & $6.9 \pm$ & $4.0 \pm$ \\
Adipose Female & 2.64 & 0.99 & 0.02 & 0.60 & 0.32 \\
\hline \hline Average & 28.5 & 11.5 & 0.3 & 7.1 & 4.2 \\
\hline \hline Standard Deviation & 3.2 & 1.8 & 0.1 & 0.9 & 0.6 \\
\hline
\end{tabular}

\subsubsection{Beta Dose to Healthcare Provider}

The beta dose to the healthcare provider from an externally contaminated patient was assumed to be only the skin dose to the hands of the healthcare provider. The surface area of the hand is approximately $1 \%$ of the surface area of the individual's body [19]. The dose received by the hands is of concern because it may result in reddening of the skin or skin burn. The dose required to produce reddening of the skin is $3 \mathrm{~Gy}$ [3]. The dose to the hands was computed by 
assuming full energy deposition for the beta particles in the same manner as the beta dose to the patient was determined. The absorbed dose to the hands of the healthcare provider for beta particles is shown in Table 4.2 for each of the isotopes. The time required for the healthcare provider to receive a dose of 3 Gy to the hands is shown in Table 4.3. The total dose to the healthcare provider including the dose to both hands from beta particles in $\mathrm{mSv} / \mathrm{hr}$ for a patient contaminated with $37 \mathrm{GBq} / \mathrm{m}^{2}$ of external contamination and in $(\mathrm{mSv} / \mathrm{hr}) / \mathrm{Bq}$ are shown in Tables 4.4 and 4.5 , respectively. The time it takes the healthcare provider to receive $250 \mathrm{mSv}$ is shown in Table 4.6.

Table 4.2 Beta Absorbed Dose to Hands of Healthcare Provider for $37 \mathrm{GBq} / \mathrm{m}^{2}$ Externally Contaminated Patient $(\mathrm{mGy} / \mathrm{hr})$

\begin{tabular}{|l|r|r|r|r|}
\hline Healthcare Provider & ${ }^{\mathbf{6 0}} \mathbf{C o}$ & \multicolumn{1}{c|}{${ }^{\mathbf{1 9 2}} \mathbf{I r}$} & \multicolumn{1}{c|}{${ }^{{ }^{137}} \mathbf{C s}$} & \multicolumn{1}{c|}{${ }^{\mathbf{3 1}} \mathbf{I}$} \\
\hline \hline Reference Male & 142.1 & 253.1 & 276.3 & 268.4 \\
\hline Reference Female & 129.1 & 229.9 & 251.0 & 243.8 \\
\hline Adipose Male & 199.0 & 354.4 & 386.8 & 375.8 \\
\hline Adipose Female & 159.0 & 283.1 & 309.0 & 300.2 \\
\hline Postmenopausal Adipose Female & 169.6 & 302.1 & 329.7 & 320.3 \\
\hline \hline Average & 159.8 & 284.5 & 310.5 & 301.7 \\
\hline \hline Standard Deviation & 26.9 & 47.8 & 52.2 & 50.7 \\
\hline
\end{tabular}

Table 4.3 Time in Hours Before the Healthcare Provider's Hands Receives a 3 Gy Dose for $37 \mathrm{GBq} / \mathrm{m}^{2}$ Externally Contaminated Patient

\begin{tabular}{|l|rrrrr|}
\hline Healthcare Provider & ${ }^{\mathbf{6 0}} \mathbf{C o}$ & ${ }^{\mathbf{1 9 2}} \mathbf{I r}$ & ${ }^{\mathbf{2 4 1}} \mathbf{A m}$ & ${ }^{\mathbf{1 3 7}} \mathbf{C s}$ & ${ }^{\mathbf{1 3 1}} \mathbf{I}$ \\
\hline \hline Reference Male & 19.8 & 11.7 & $7.92 \mathrm{E}+03$ & 10.7 & 11.1 \\
Reference Female & 20.7 & 12.7 & $9.75 \mathrm{E}+03$ & 11.8 & 12.2 \\
Adipose Male & 14.3 & 8.4 & $6.32 \mathrm{E}+03$ & 7.7 & 7.9 \\
Adipose Female & 16.9 & 10.3 & $3.95 \mathrm{E}+03$ & 9.6 & 9.9 \\
Postmenopausal Adipose Female & 16.1 & 9.7 & $4.31 \mathrm{E}+03$ & 9.0 & 9.3 \\
\hline
\end{tabular}


Table 4.4 Total Effective Dose to Healthcare Provider for $37 \mathrm{GBq} / \mathrm{m}^{2}$ Externally Contaminated Patient (mSv/hr)

\begin{tabular}{|l|c|c|c|c|c|}
\hline Healthcare Provider & ${ }^{\mathbf{6 0}} \mathbf{C o}$ & ${ }^{\mathbf{1 9 2}} \mathbf{I r}$ & ${ }^{\mathbf{2 4 1}} \mathbf{A m}$ & ${ }^{\mathbf{1 3 7}} \mathbf{C s}$ & ${ }^{\mathbf{1 3 1}} \mathbf{I}$ \\
\hline \hline Reference Male & 31.6 & 15.3 & 0.4 & 10.5 & 7.4 \\
\hline Reference Female & 32.9 & 15.9 & 0.4 & 10.6 & 7.4 \\
\hline Adipose Male & 27.2 & 13.1 & 0.4 & 10.0 & 7.4 \\
\hline Adipose Female & 28.7 & 13.5 & 0.3 & 9.8 & 7.0 \\
\hline Postmenopausal Adipose Female & 30.3 & 13.9 & 0.3 & 10.2 & 7.2 \\
\hline \hline Average & 30.1 & 14.4 & 0.4 & 10.2 & 7.3 \\
\hline \hline Standard Deviation & 2.3 & 1.2 & 0.1 & 0.3 & 0.2 \\
\hline
\end{tabular}

Table 4.5 Total Effective Dose to Healthcare Provider Due to Externally Contaminated Patient $(\mathrm{mSv} / \mathrm{hr}) / \mathrm{Bq}$

\begin{tabular}{|c|r|r|r|c|c|}
\hline Healthcare Provider & ${ }^{{ }^{60}} \mathbf{C o}$ & ${ }^{192} \mathbf{I r}$ & ${ }^{241} \mathbf{A m}$ & ${ }^{137} \mathbf{C s}$ & ${ }^{131} \mathbf{I}$ \\
\hline \hline Reference Male & $4.74795 \mathrm{E}-10$ & $2.3 \mathrm{E}-10$ & $6 \mathrm{E}-12$ & $1.6 \mathrm{E}-10$ & $1.1 \mathrm{E}-10$ \\
\hline Reference Female & $4.9386 \mathrm{E}-10$ & $2.4 \mathrm{E}-10$ & $6 \mathrm{E}-12$ & $1.6 \mathrm{E}-10$ & $1.1 \mathrm{E}-10$ \\
\hline Adipose Male & $4.08256 \mathrm{E}-10$ & $2 \mathrm{E}-10$ & $6 \mathrm{E}-12$ & $1.5 \mathrm{E}-10$ & $1.1 \mathrm{E}-10$ \\
\hline Adipose Female & $4.30774 \mathrm{E}-10$ & $2 \mathrm{E}-10$ & $4.5 \mathrm{E}-12$ & $1.5 \mathrm{E}-10$ & $1.1 \mathrm{E}-10$ \\
\hline Postmenopausal Adipose Female & $4.54897 \mathrm{E}-10$ & $2.1 \mathrm{E}-10$ & $4.5 \mathrm{E}-12$ & $1.5 \mathrm{E}-10$ & $1.1 \mathrm{E}-10$ \\
\hline
\end{tabular}

Table 4.6 Time in Hours Before Healthcare Provider Receives a $250 \mathrm{mSv}$ Dose for $37 \mathrm{GBq} / \mathrm{m}^{2}$ Externally Contaminated Patient

\begin{tabular}{|l|r|r|r|r|r|}
\hline Healthcare Provider & \multicolumn{1}{|c|}{${ }^{\mathbf{6 0}} \mathbf{C o}$} & \multicolumn{1}{c|}{${ }^{\mathbf{1 9 2}} \mathbf{I r}$} & ${ }^{\mathbf{2 4 1}} \mathbf{A m}$ & \multicolumn{1}{c|}{${ }^{\mathbf{1 3 7}} \mathbf{C s}$} & ${ }^{\mathbf{1 3 1}} \mathbf{I}$ \\
\hline \hline Reference Male & 7.9 & 16.3 & 625.0 & 23.9 & 33.9 \\
\hline Reference Female & 7.6 & 15.7 & 625.0 & 23.6 & 33.6 \\
\hline Adipose Male & 9.2 & 19.0 & 625.0 & 25.1 & 34.0 \\
\hline Adipose Female & 8.7 & 18.5 & 833.3 & 25.5 & 35.7 \\
\hline Postmenopausal Adipose Female & 8.3 & 18.0 & 833.3 & 24.5 & 34.7 \\
\hline \hline Average & 8.3 & 17.5 & 708.3 & 24.5 & 34.4 \\
\hline \hline Standard Deviation & 0.6 & 1.4 & 114.1 & 0.8 & 0.9 \\
\hline
\end{tabular}




\subsection{Internally Contaminated Patients}

The dose received by the healthcare provider is much more complicated to predict from an internally contaminated patient than an externally contaminated patient. The location of the radioactive material in the body of the patient is dependent on isotope and time, in addition to the body type of the patient, the body type of the healthcare provider and the type and energy of the emitted radiation. This means that the patterns in the dose rate as a function of body type are much more strongly dependent on the isotope the patient has been exposed to. The distribution of the different isotopes six hours after inhalation are given in Table 4.7, and the effects of the isotope on the effective dose rate received by the healthcare provider from different patients are shown in Figures 4.2 through 4.9. 
Table 4.7 Inhalation Class and Fraction of Isotope in Each Compartment Six Hours after Inhalation

\begin{tabular}{|c|c|c|c|c|c|}
\hline Lung & $\begin{array}{c}{ }^{\mathbf{6 0}} \mathbf{C} \\
\text { (slow) }\end{array}$ & $\begin{array}{c}{ }^{\mathbf{6 0}} \mathbf{C} \\
\text { (moderate) }\end{array}$ & $\begin{array}{c}{ }^{\mathbf{2 4 1}} \text { Am } \\
\text { (moderate) }\end{array}$ & $\begin{array}{c}{ }^{192} \mathbf{I r} \\
\text { (slow) }\end{array}$ & $\begin{array}{c}{ }^{192} \text { Ir } \\
\text { (moderate) }\end{array}$ \\
\hline \hline Stomach & $2.72 \mathrm{E}-01$ & $2.40 \mathrm{E}-01$ & $2.42 \mathrm{E}-01$ & $3.12 \mathrm{E}-01$ & $2.97 \mathrm{E}-01$ \\
\hline Small Intestine & $1.85 \mathrm{E}-03$ & $1.51 \mathrm{E}-03$ & $1.71 \mathrm{E}-03$ & $1.20 \mathrm{E}-01$ & $1.14 \mathrm{E}-01$ \\
\hline Blood & $8.65 \mathrm{E}-02$ & $5.31 \mathrm{E}-02$ & $6.32 \mathrm{E}-02$ & $4.79 \mathrm{E}-02$ & $4.61 \mathrm{E}-02$ \\
\hline Ascending Colon & $3.41 \mathrm{E}-03$ & $2.87 \mathrm{E}-02$ & $2.94 \mathrm{E}-04$ & $2.42 \mathrm{E}-04$ & $2.16 \mathrm{E}-02$ \\
\hline Transverse Colon & $8.61 \mathrm{E}-02$ & $4.16 \mathrm{E}-02$ & $4.30 \mathrm{E}-02$ & $6.56 \mathrm{E}-04$ & $6.60 \mathrm{E}-04$ \\
\hline Descending Colon & $1.89 \mathrm{E}-02$ & $5.54 \mathrm{E}-02$ & $5.74 \mathrm{E}-02$ & $8.74 \mathrm{E}-04$ & $8.79 \mathrm{E}-04$ \\
\hline Sigmoid Colon & $1.47 \mathrm{E}-02$ & $9.56 \mathrm{E}-03$ & $9.21 \mathrm{E}-03$ & $5.10 \mathrm{E}-04$ & $5.13 \mathrm{E}-04$ \\
\hline Other & $2.95 \mathrm{E}-04$ & $4.01 \mathrm{E}-03$ & $7.63 \mathrm{E}-03$ & $5.60 \mathrm{E}-06$ & $5.34 \mathrm{E}-04$ \\
\hline Liver & $3.28 \mathrm{E}-05$ & $4.45 \mathrm{E}-04$ & $9.04 \mathrm{E}-03$ & $2.07 \mathrm{E}-06$ & $1.98 \mathrm{E}-04$ \\
\hline Urinary Bladder & $4.82 \mathrm{E}-05$ & $1.32 \mathrm{E}-03$ & $1.53 \mathrm{E}-04$ & $9.35 \mathrm{E}-07$ & $8.90 \mathrm{E}-05$ \\
\hline Bone Surface & ---- & ---- & $5.44 \mathrm{E}-03$ & ---- & ---- \\
\hline Kidneys & ---- & ---- & $4.47 \mathrm{E}-04$ & $4.15 \mathrm{E}-07$ & $3.96 \mathrm{E}-05$ \\
\hline Testes & ---- & ---- & $6.39 \mathrm{E}-06$ & ---- & ---- \\
\hline Ovaries & ---- & ---- & $2.03 \mathrm{E}-06$ & ----- & ---- \\
\hline Bone Volume & ---- & ---- & $1.53 \mathrm{E}-07$ & ---- & ---- \\
\hline Bone Marrow & ---- & ---- & $2.61 \mathrm{E}-07$ & ---- & ---- \\
\hline Body Tissue & ---- & ---- & ---- & ---- & ---- \\
\hline Spleen & ---- & ---- & ---- & $2.07 \mathrm{E}-07$ & $1.98 \mathrm{E}-05$ \\
\hline Thyroid & ---- & ---- & ---- & ---- & ---- \\
\hline
\end{tabular}


Table 4.7 (Continued)

\begin{tabular}{|c|c|c|c|}
\hline Lung & $\begin{array}{c}{ }^{192} \mathbf{I r} \\
\text { (fast) }\end{array}$ & $\begin{array}{c}{ }^{137} \mathbf{C s} \\
\text { (fast) }\end{array}$ & ${ }^{\mathbf{1 3 1} \text { I (fast) }}$ \\
\hline \hline Stomach & $1.63 \mathrm{E}-01$ & $1.16 \mathrm{E}-01$ & $1.14 \mathrm{E}-01$ \\
\hline Small Intestine & $6.18 \mathrm{E}-02$ & $2.85 \mathrm{E}-04$ & $2.79 \mathrm{E}-04$ \\
\hline Blood & $3.03 \mathrm{E}-02$ & $1.19 \mathrm{E}-05$ & $1.17 \mathrm{E}-05$ \\
\hline Ascending Colon & $6.15 \mathrm{E}-01$ & $1.78 \mathrm{E}-01$ & $1.74 \mathrm{E}-01$ \\
\hline Transverse Colon & $9.28 \mathrm{E}-04$ & $3.43 \mathrm{E}-04$ & $2.77 \mathrm{E}-04$ \\
\hline Descending Colon & $6.96 \mathrm{E}-04$ & $1.56 \mathrm{E}-04$ & $1.42 \mathrm{E}-04$ \\
\hline Sigmoid Colon & $5.41 \mathrm{E}-04$ & $1.22 \mathrm{E}-04$ & $1.10 \mathrm{E}-04$ \\
\hline Other & $5.34 \mathrm{E}-03$ & ---- & $5.19 \mathrm{E}-05$ \\
\hline Liver & $1.98 \mathrm{E}-03$ & ---- & ---- \\
\hline Urinary Bladder & $8.89 \mathrm{E}-04$ & $2.91 \mathrm{E}-04$ & $3.18 \mathrm{E}-02$ \\
\hline Bone Surface & ---- & ---- & ---- \\
\hline Kidneys & $3.95 \mathrm{E}-04$ & ---- & ---- \\
\hline Testes & ----- & ---- & ---- \\
\hline Ovaries & ----- & ---- & ---- \\
\hline Bone Volume & ---- & ---- & ---- \\
\hline Bone Marrow & ---- & ---- & ---- \\
\hline Body Tissue & ---- & $1.57 \mathrm{E}-01$ & ---- \\
\hline Spleen & $1.98 \mathrm{E}-04$ & ---- & ---- \\
\hline Thyroid & ---- & ---- & $4.63 \mathrm{E}-02$ \\
\hline
\end{tabular}

The distribution of the isotope in the body affects the dose to the healthcare provider. For ${ }^{60} \mathrm{Co}$ and ${ }^{241} \mathrm{Am}$, the radioisotopes are concentrated in the lungs and large intestines after six hours as shown in Table 4.7. The affects of the body type of the healthcare provider and the patient on the effective dose rate are shown in Figures 4.2 through 4.4. The adipose patients provide more shielding for the healthcare provider. The postmenopausal adipose female and the adipose male patients result in the lowest dose to the healthcare provider due to the large amount of interstitial fat in the abdomen area. The adipose female produces a marginally higher effective dose rate to the healthcare provider. The reference female and reference male patients 
result in the highest effective dose rates in the healthcare provider. The slow uptake class for ${ }^{60}$ Co produced a higher effective dose to the healthcare provider than the moderate uptake class due to the retention of the isotope in the patient's body.

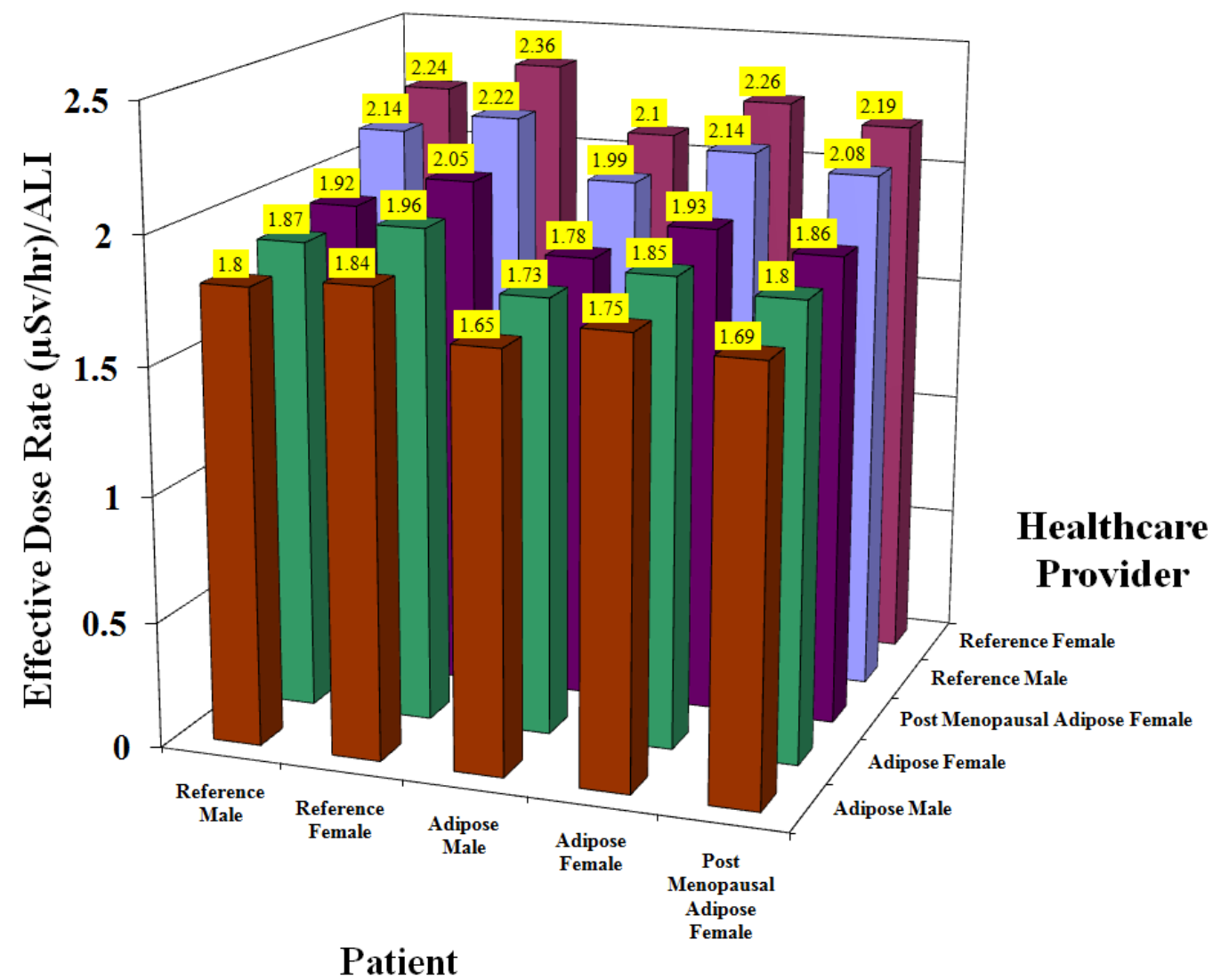

Figure 4.2 Effective Dose Rate to Healthcare Provider Due to ${ }^{60} \mathrm{Co}$ (slow) 


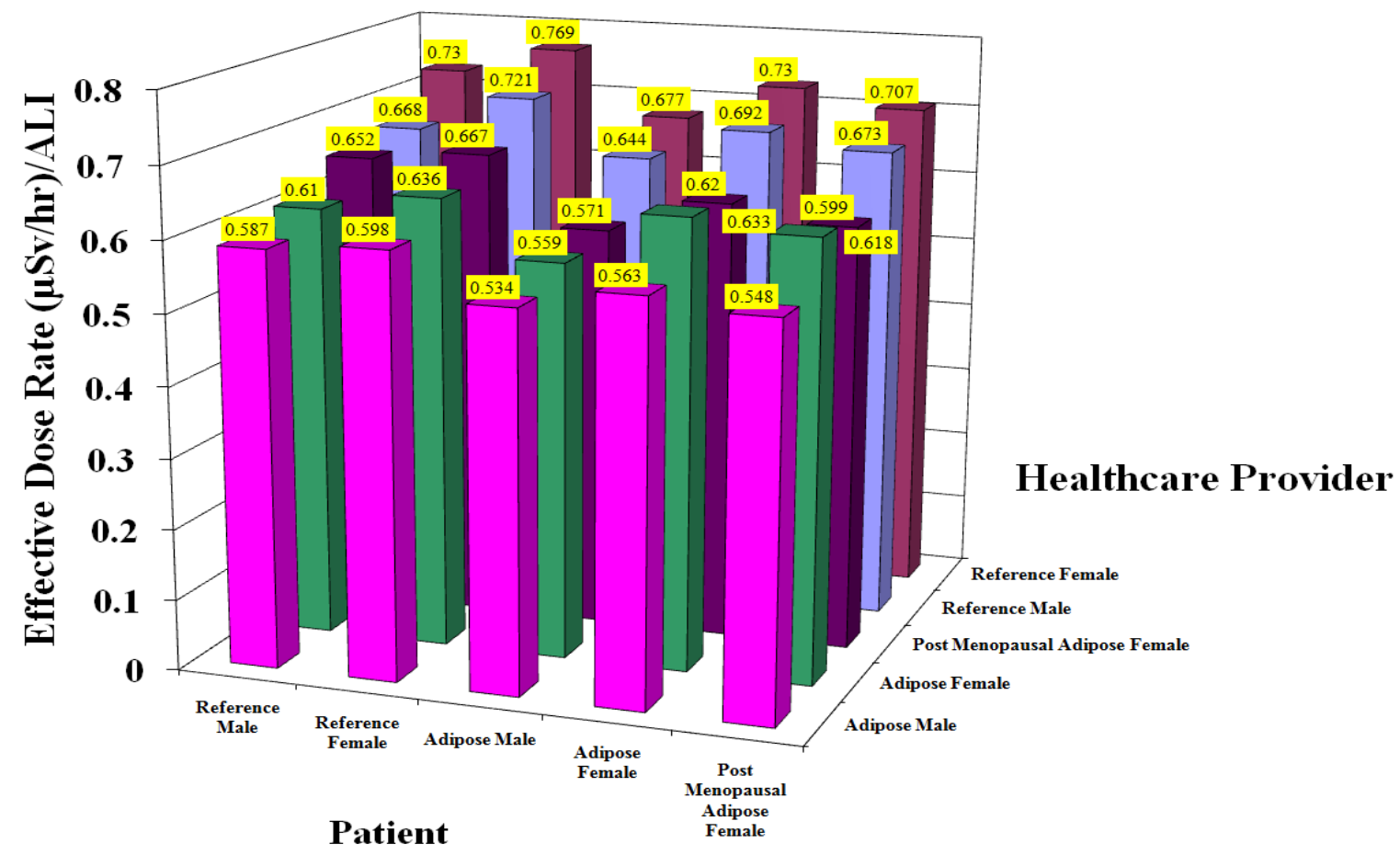

Figure 4.3 Effective Dose Rate to Healthcare Provider Due to ${ }^{60} \mathrm{Co}$ (moderate)

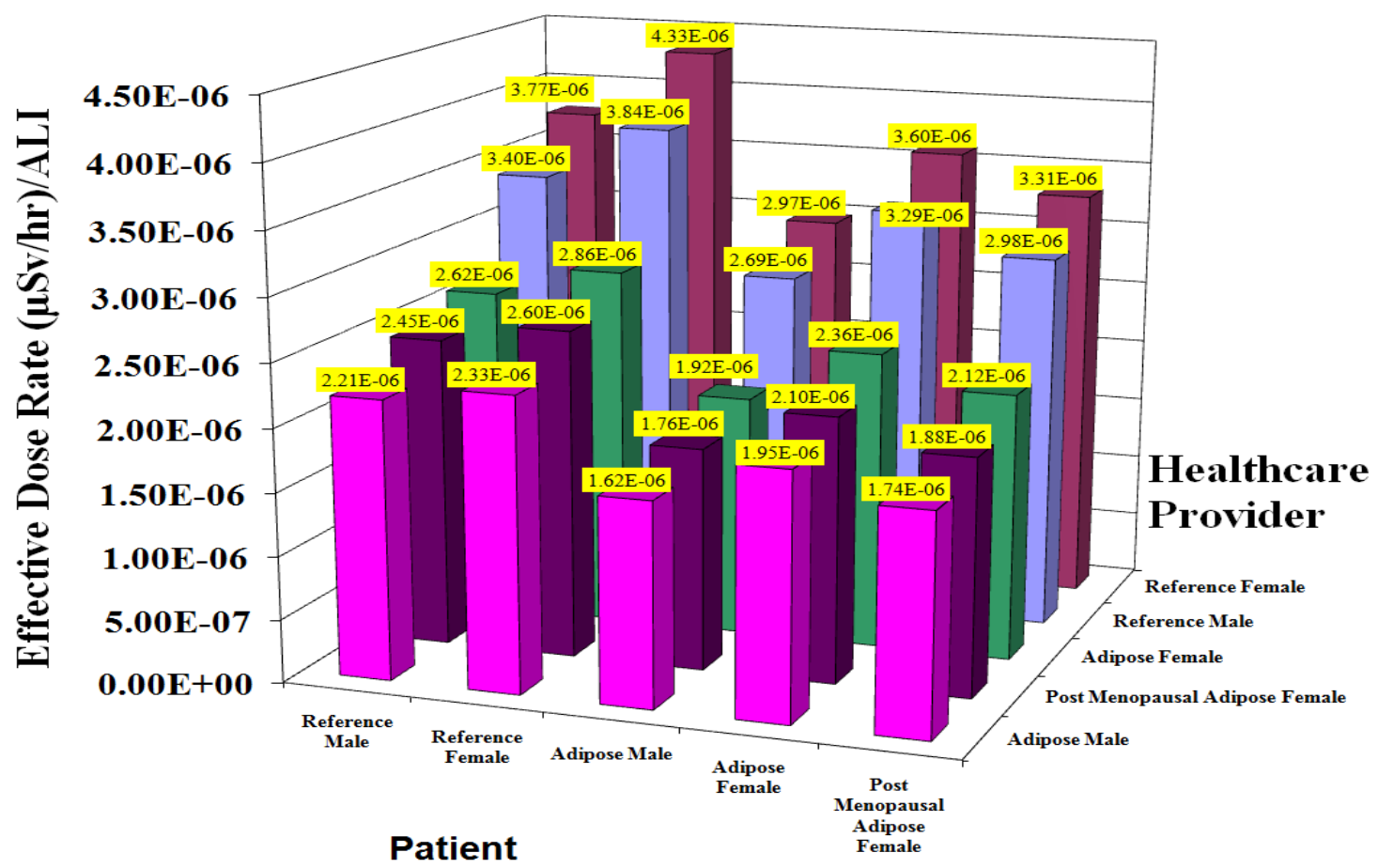

Figure 4.4 Effective Dose Rate to Healthcare Provider Due to ${ }^{241} \mathrm{Am}$ 
${ }^{192}$ Ir distributes itself much differently in the body than ${ }^{60}$ Co. As shown in Table 4.7, ${ }^{192} \mathrm{Ir}$ is dispersed in the lungs, liver, blood, large intestines, and small intestines after six hours. The uptake class for ${ }^{192}$ Ir affected the dose to the healthcare provider due to the retention rate of the isotope in the body as shown in Figures 4.5 through 4.7. The highest effective dose to the healthcare provider due to ${ }^{192} \mathrm{Ir}$ is for the slow uptake class. The reference female and reference male patients cause the healthcare provider to receive the highest effective doses due to the lack of shielding in the abdominal area. The additional adipose tissue in the abdominal area of the adipose patients provides some shielding for the healthcare provider depending on the thickness of the adipose layer. The third highest effective dose to the healthcare provider is caused by the adipose female since she has the smallest adipose layer in the abdominal region. The lowest effective doses are produced by the postmenopausal adipose female and the adipose male due to the large amount of adipose tissue in the abdominal region. 


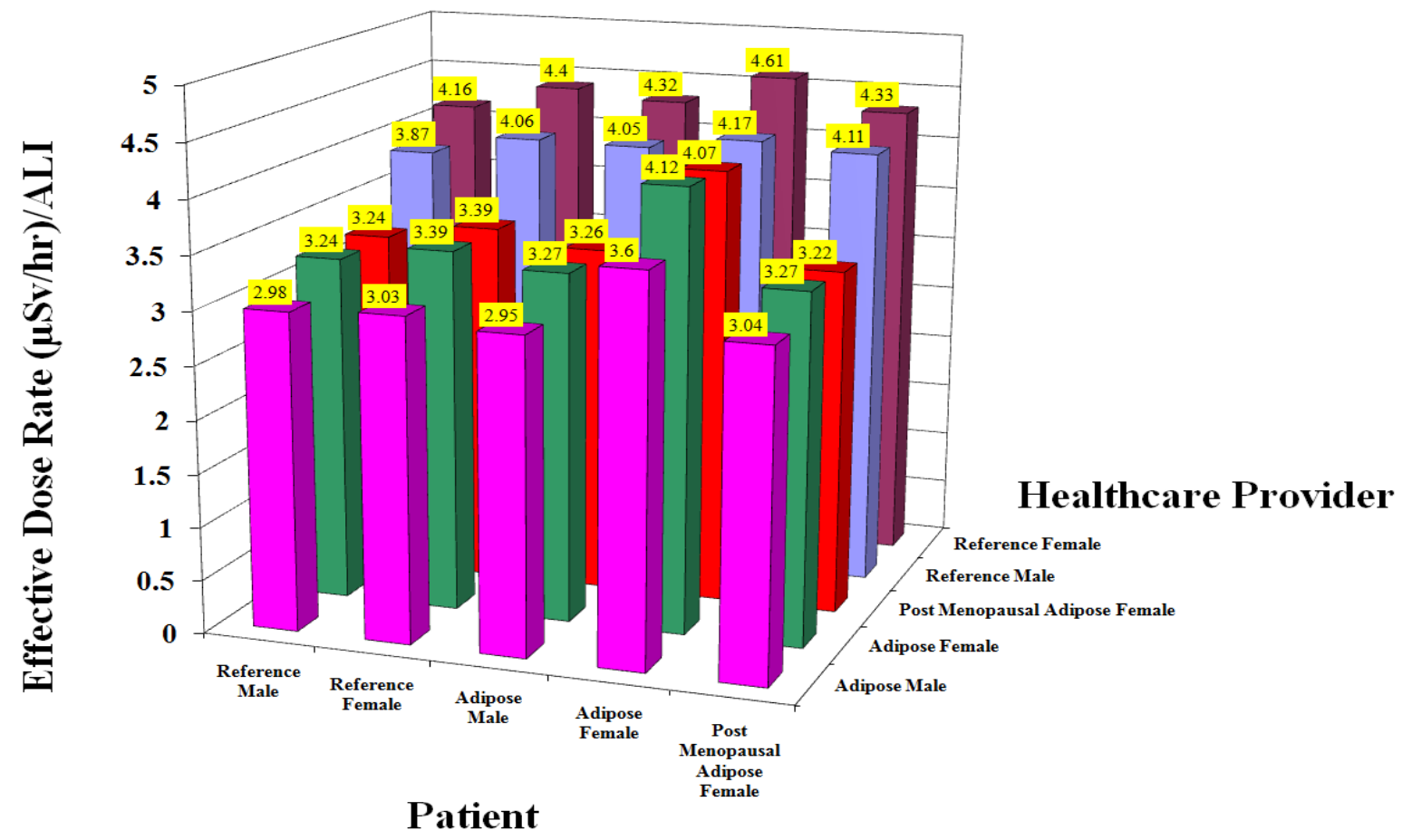

Figure 4.5 Effective Dose Rate to Healthcare Provider Due to ${ }^{192} \operatorname{Ir}$ (slow)

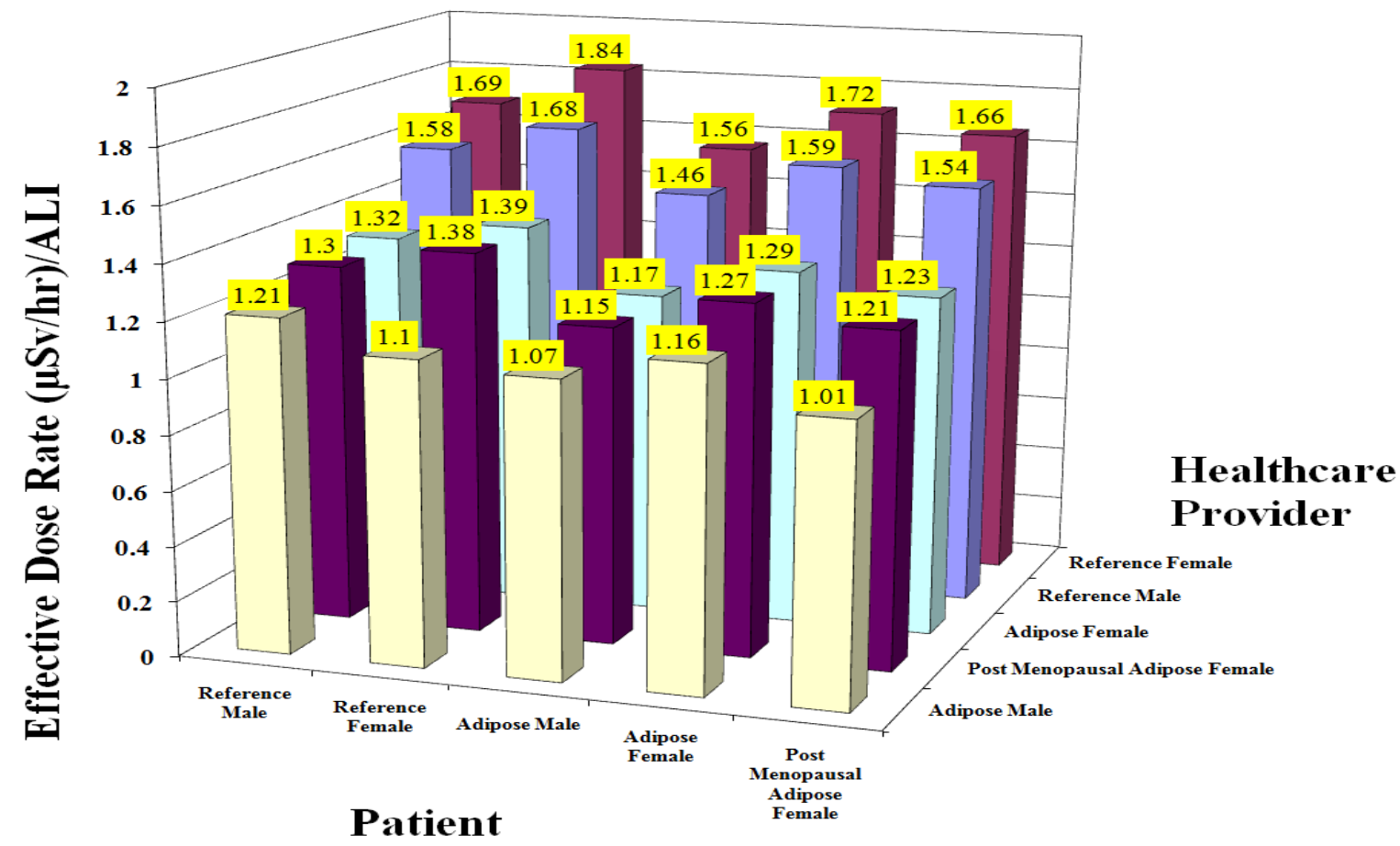

Figure 4.6 Effective Dose Rate to Healthcare Provider Due to ${ }^{192}$ Ir (moderate) 


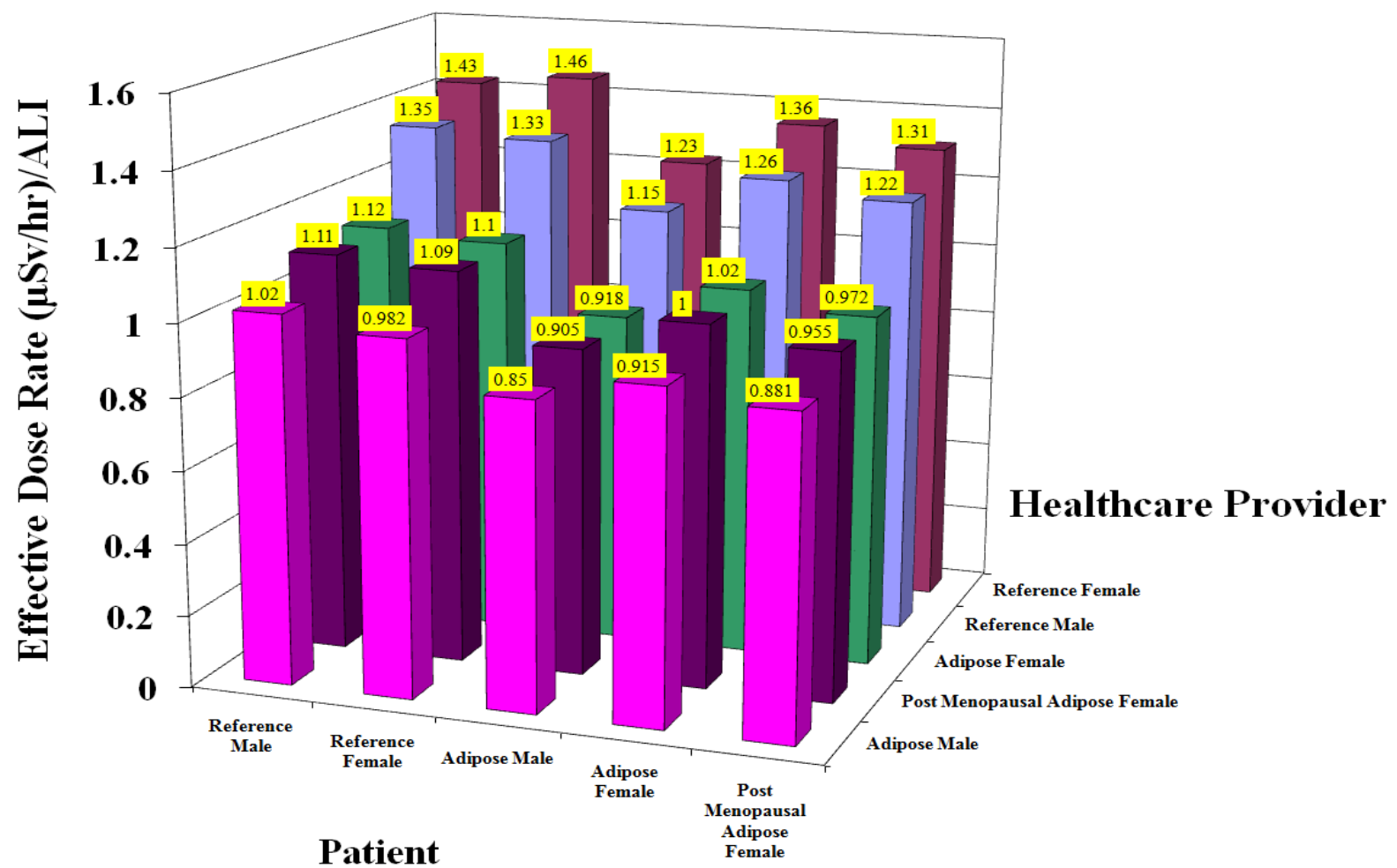

Figure 4.7 Effective Dose Rate to Healthcare Provider Due to ${ }^{192}$ Ir (fast)

${ }^{137} \mathrm{Cs}$ tends to distribute itself uniformly throughout the body tissue and blood after six hours as shown in Table 4.7. The dose to the healthcare provider as a function of the patient's body type for ${ }^{137} \mathrm{Cs}$ is depicted in Figure 4.8. The adipose male and the postmenopausal adipose female patients result in the highest dose to the healthcare provider because they have the largest amount of body tissue in close proximity to the healthcare provider. The postmenopausal adipose female patient produces a slightly higher effective dose rate than the adipose male due to the combination of the adipose tissue on the abdomen and the breast tissue. The adipose female results in the third highest effective dose rate due to the increase in body tissue over the reference male and reference female. The reference male and reference female result in the lowest effective dose rates to the healthcare provider. 


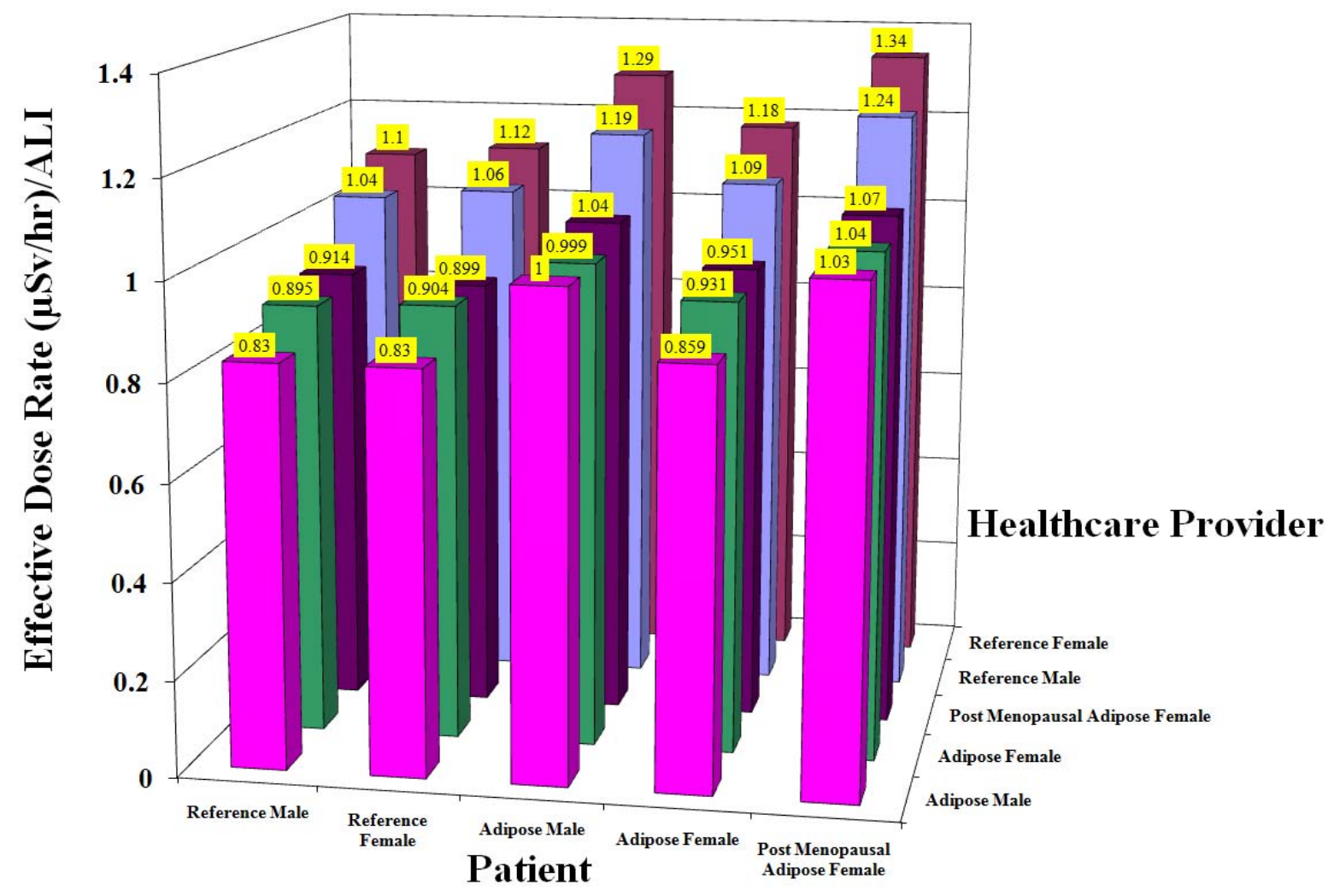

Figure 4.8 Effective Dose Rate to Healthcare Provider Due to ${ }^{137} \mathrm{Cs}$

${ }^{131} \mathrm{I}$ is mainly distributed in the lungs, blood and thyroid six hours after inhalation as shown in Table 4.7. The reference male and reference female patients result in the highest effective dose to the healthcare provider due to the reduction in shielding due to the absence of adipose tissue. The adipose female patient produces the third highest effective dose rate in the healthcare provider for a combination of reasons. Although the adipose female does not have as much adipose tissue as the adipose male and the postmenopausal adipose female, the additional tissue present in the abdominal area and the breasts reduces the effective dose to the healthcare provider. The adipose male and the postmenopausal adipose female phantoms have the same amount of blood dispersed in the body as the other phantoms, thus diluting the effects of the radioisotope present in the blood. The additional breast tissue aids in shielding the heart and 
lungs from the healthcare provider. This combination causes the adipose male and the postmenopausal adipose female to produce the lowest effective dose rates in the healthcare provider. These trends are shown in Figure 4.9.

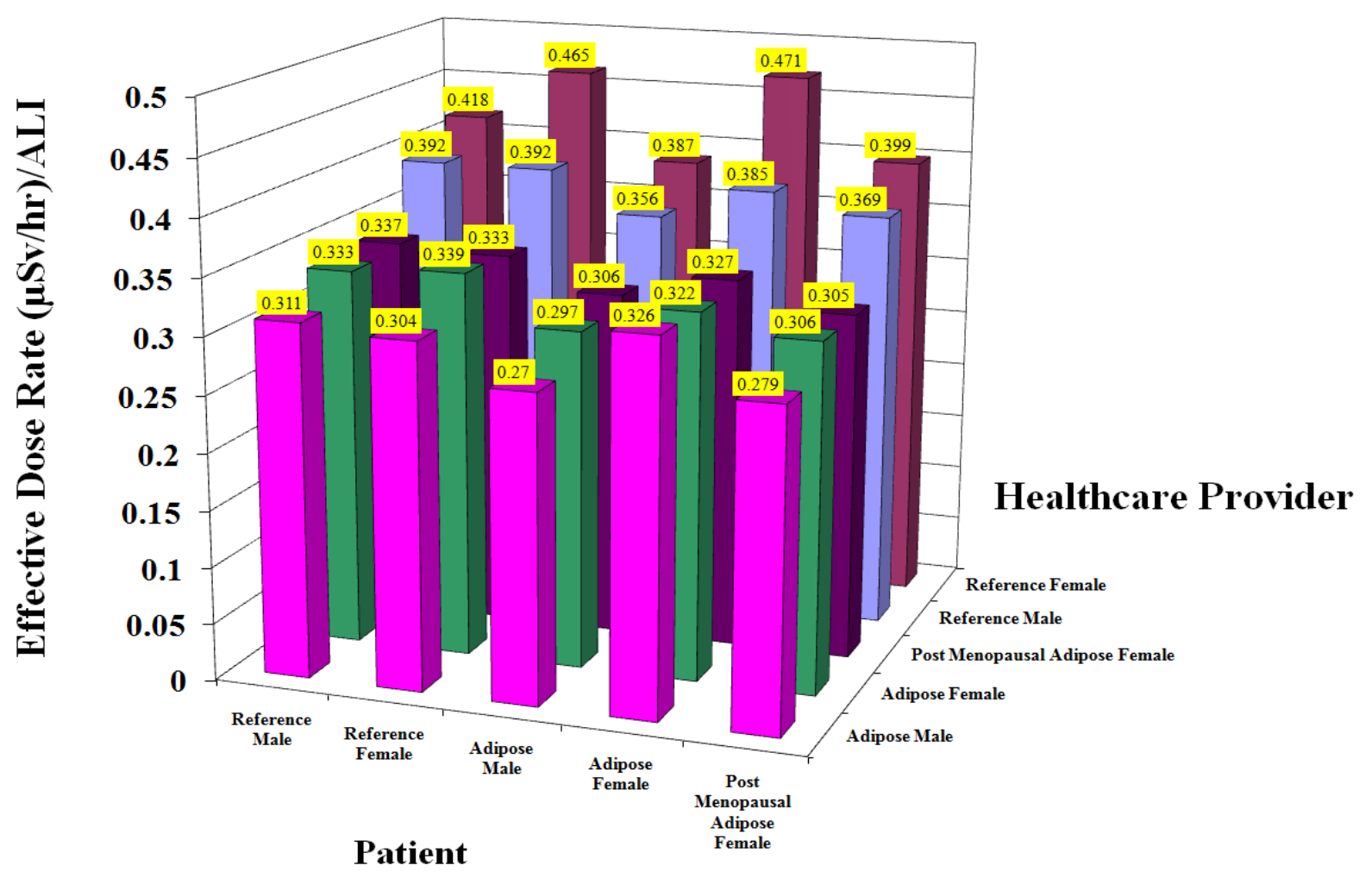

Figure 4.9 Effective Dose Rate to Healthcare Provider Due to ${ }^{131} \mathrm{I}$

The trend of the effect of the body type of the healthcare provider on the effective dose rate is consistent with that found for the externally contaminated patients and is constant over all isotopes. The reference female healthcare provider receives the largest dose due to the exposure of the breast tissue and the lack of adipose tissue to shield the radiosensitive internal organs. The 
reference male healthcare provider receives the second highest dose due to the absence of adipose tissue to shield his internal organs. The operating table also provided shielding to the gonads for the reference male. The postmenopausal adipose female and the adipose female receive the third and fourth highest effective dose rates due to the exposure of the breast tissue and the addition of adipose tissue to shield the internal organs. The adipose male receives the lowest effective dose rate due to the additional shielding provided by the adipose tissue and the operating table for his gonads.

The organ that received the highest and lowest contribution to the effective dose largely seemed to be independent of the body type of both the healthcare provider and the patient. For the reference male, reference female and the adipose male healthcare providers, the highest contribution to the effective dose was delivered to either the stomach or the colon for all isotopes. This is due to the high tissue weighting factor for and their organs there proximity to the patient. For the adipose female and postmenopausal adipose female healthcare providers, the highest contribution to the effective dose was to the colon or stomach for all isotopes except ${ }^{241}$ Am. For ${ }^{241}$ Am, the highest contribution to the effective dose was contributed by the breasts. This is due to the low energy gamma ray emitted by ${ }^{241} \mathrm{Am}$, the increased breast size of the adipose female healthcare provider, and the additional shielding provided by the adipose tissue. The minimum contribution to the effective dose was delivered to the skin for all body types of both the healthcare provider and the patient and the isotope of contamination. The contribution to the effective dose rate to each organ and the absorbed dose for each organ for the different healthcare providers irradiated by internally contaminated patients are shown in Appendix $\mathbf{J}$ and M, respectively. 
The isotope and uptake class for inhalation greatly affect the dose to the healthcare provider. The effective doses for the different isotopes per ALI inhaled by the patient are shown in Table 4.8. The highest effective dose rate is ${ }^{192} \operatorname{Ir}$ with a slow inhalation class. This is due to the concentration of ${ }^{192} \mathrm{Ir}$ in the organs located in the abdomen region and the higher retention rate for the slow intake class. The healthcare provider was placed $20-\mathrm{cm}$ from the abdomen of the patient greatly increasing the dose from isotopes concentrated in this region. The lowest effective dose rate is due to ${ }^{241} \mathrm{Am}$ because it emits a low energy gamma ray. The effective dose rates due to the other isotopes are dependent on a combination on gamma ray energy, intensity and distribution in the body of the patient.

Table 4.8 Effective Dose to Healthcare Providers from Patients with Internal Contamination

\begin{tabular}{|c|c|c|c|c|c|c|c|c|}
\hline $\begin{array}{c}\text { Healthcare } \\
\text { Provider }\end{array}$ & $\begin{array}{l}{ }^{60} \mathrm{Co} \\
(\mathrm{m}) \\
\end{array}$ & $\begin{array}{c}{ }^{60} \mathrm{Co} \\
(\mathrm{s}) \\
\end{array}$ & $\begin{array}{c}{ }^{192} \mathrm{Ir} \\
\text { (f) }\end{array}$ & $\begin{array}{l}{ }^{192} \mathrm{Ir} \\
(\mathrm{m})\end{array}$ & $\begin{array}{c}{ }^{192} \mathrm{Ir} \\
(\mathrm{s}) \\
\end{array}$ & ${ }^{241} \mathrm{Am}$ & ${ }^{137} \mathrm{Cs}$ & ${ }^{131} \mathbf{I}$ \\
\hline $\begin{array}{l}\text { Reference } \\
\text { Male }\end{array}$ & $\begin{array}{l}0.7 \pm \\
0.03\end{array}$ & $\begin{array}{l}2.1 \pm \\
0.09\end{array}$ & $\begin{array}{l}1.3 \pm \\
0.08\end{array}$ & $\begin{array}{l}1.6 \pm \\
0.08\end{array}$ & $\begin{array}{l}4.1 \pm \\
0.11\end{array}$ & $\begin{array}{c}3.24 \mathrm{E}-06 \pm \\
4.35 \mathrm{E}-07\end{array}$ & $\begin{array}{c}1.12 \\
\pm \\
0.09\end{array}$ & $\begin{array}{c}0.38 \pm \\
0.02\end{array}$ \\
\hline $\begin{array}{l}\text { Reference } \\
\text { Female }\end{array}$ & $\begin{array}{c}0.7 \pm \\
0.03\end{array}$ & $\begin{array}{c}2.2 \pm \\
0.10\end{array}$ & $\begin{array}{l}1.4 \pm \\
0.09\end{array}$ & $\begin{array}{l}1.7 \pm \\
0.10\end{array}$ & $\begin{array}{l}4.4 \pm \\
0.16\end{array}$ & $\begin{array}{c}3.60 \mathrm{E}-06 \pm \\
5.11 \mathrm{E}-07\end{array}$ & $\begin{array}{c}1.21 \\
\pm \\
0.11\end{array}$ & $\begin{array}{c}0.41 \pm \\
0.01\end{array}$ \\
\hline Adipose Male & $\begin{array}{c}0.6 \pm \\
0.03\end{array}$ & $\begin{array}{l}1.7 \pm \\
0.08\end{array}$ & $\begin{array}{c}0.9 \pm \\
0.07\end{array}$ & $\begin{array}{l}1.1 \pm \\
0.08\end{array}$ & $\begin{array}{l}3.1 \pm \\
0.27\end{array}$ & $\begin{array}{c}1.97 \mathrm{E}-06 \pm \\
3.01 \mathrm{E}-07\end{array}$ & $\begin{array}{c}0.91 \\
\pm \\
0.10\end{array}$ & $\begin{array}{c}0.29 \pm \\
0.02\end{array}$ \\
\hline $\begin{array}{c}\text { Adipose } \\
\text { Female }\end{array}$ & $\begin{array}{c}0.6 \pm \\
0.03\end{array}$ & $\begin{array}{l}1.8 \pm \\
0.09\end{array}$ & $\begin{array}{l}1.0 \pm \\
0.09\end{array}$ & $\begin{array}{l}1.3 \pm \\
0.08\end{array}$ & $\begin{array}{l}3.5 \pm \\
0.37\end{array}$ & $\begin{array}{c}2.38 \mathrm{E}-06 \pm \\
3.77 \mathrm{E}-07\end{array}$ & $\begin{array}{c}0.95 \\
\pm \\
0.06\end{array}$ & $\begin{array}{c}0.32 \pm \\
0.02\end{array}$ \\
\hline $\begin{array}{c}\text { Postmenopaus } \\
\text { al Adipose } \\
\text { Female } \\
\end{array}$ & $\begin{array}{c}0.6 \pm \\
0.04\end{array}$ & $\begin{array}{l}1.9 \pm \\
0.10\end{array}$ & $\begin{array}{l}1.0 \pm \\
0.09\end{array}$ & $\begin{array}{l}1.3 \pm \\
0.09\end{array}$ & $\begin{array}{l}3.4 \pm \\
0.36\end{array}$ & $\begin{array}{c}2.16 \mathrm{E}-06 \pm \\
3.60 \mathrm{E}-07\end{array}$ & $\begin{array}{c}0.97 \\
\pm \\
0.08 \\
\end{array}$ & $\begin{array}{c}0.32 \pm \\
0.02\end{array}$ \\
\hline Average & 0.6 & 2.0 & 1.1 & 1.4 & 3.7 & $2.67 \mathrm{E}-06$ & 1.03 & 0.35 \\
\hline $\begin{array}{l}\text { Standard } \\
\text { Deviation }\end{array}$ & 0.1 & 0.2 & 0.2 & 0.2 & 0.5 & $7.46 \mathrm{E}-07$ & 0.14 & 0.05 \\
\hline
\end{tabular}




\subsection{Comparison of Dose to Healthcare Provider Due to Internally and Externally Contaminated Patients}

Comparisons between the dose to healthcare provider due to a patient with internal contamination for the slowest uptake class considered and a patient with $37 \mathrm{GBq} / \mathrm{m}^{2}$ for ${ }^{60} \mathrm{Co}$, ${ }^{192} \mathrm{Ir},{ }^{241} \mathrm{Am},{ }^{137} \mathrm{Cs}$, and ${ }^{131} \mathrm{I}$ are shown in Tables 4.9.

Table 4.9 Dose to Healthcare Provider from patient for 1 ALI Internal Contamination and 37 $\mathrm{GBq} / \mathrm{m}^{2}$ External Contamination for ${ }^{60} \mathrm{Co}$ in $\mathrm{mSv} / \mathrm{hr}$

\begin{tabular}{|c|c|c|c|c|c|}
\hline $\begin{array}{c}\text { Type of } \\
\text { Contamination }\end{array}$ & ${ }^{\mathbf{6 0}} \mathbf{C o}(\mathbf{s})$ & ${ }^{\mathbf{1 9 2} \mathbf{I r}(\mathbf{s})}$ & ${ }^{{ }^{241}} \mathbf{A m}$ & ${ }^{\mathbf{1 3 7}^{7}} \mathbf{C s}$ & ${ }^{\mathbf{1 3 1}_{\mathbf{I}}}$ \\
\hline \hline Internal $(\mu \mathrm{Sv} / \mathrm{hr})$ & 2.0 & 3.7 & $2.67 \mathrm{E}-06$ & 1.03 & 0.35 \\
\hline External $(\mathrm{mSv} / \mathrm{hr})$ & 30.1 & 14.4 & 0.4 & 10.2 & 7.3 \\
\hline
\end{tabular}

The general trends of the dose to the healthcare provider due to contaminated patients are generally the same for both the internally and externally contaminated patients. The distribution of ${ }^{192} \mathrm{Ir}$ and ${ }^{60} \mathrm{Co}$ in the body for the internally contaminated patient results in the ${ }^{192} \mathrm{Ir}$ causing a higher effective dose rate in the healthcare provider. The internally contaminated patients result in a significantly smaller dose to the healthcare provider especially for ${ }^{241} \mathrm{Am}$.

The time the healthcare provider can operate on the contaminated patient before reaching a predetermined limit is determined by whether the contamination is internal or external and the isotope of contamination. For internally contaminated patients, the dose rate received by the healthcare provider is continuously changing with time, so it is not possible to determine the amount of time it takes the healthcare provider to receive a specific dose without further analysis. The amount of time in hours the healthcare provider can safely operate on the externally 
contaminated patients before receiving doses of $50 \mathrm{mSv}$ and $250 \mathrm{mSv}$ are depicted in Tables

4.10.

Table 4.10 Time (Hours) It Takes for Healthcare Provider to Receive $50 \mathrm{mSv}$ and $250 \mathrm{mSv}$ Dose from $37 \mathrm{GBq} / \mathrm{m}^{2}$ Externally Contaminated Patient

\begin{tabular}{|c|c|c|c|c|c|}
\hline $\begin{array}{c}\text { Dose to Healthcare } \\
\text { Provider }\end{array}$ & ${ }^{\mathbf{6 0}} \mathbf{C o}(\mathbf{s})$ & ${ }^{\mathbf{1 9 2}} \mathbf{I r} \mathbf{( s )}$ & ${ }^{{ }^{241}} \mathbf{A m}$ & ${ }^{{ }^{137}} \mathbf{C s}$ & ${ }^{\mathbf{1 3 1}} \mathbf{I}$ \\
\hline \hline $\mathbf{5 0} \mathbf{~ m S v}$ & 1.7 & 3.5 & 125.0 & 4.9 & 6.8 \\
\hline $\mathbf{2 5 0} \mathbf{~ m S v}$ & 8.3 & 17.5 & 708.3 & 24.5 & 34.4 \\
\hline
\end{tabular}

A comparison of the findings from this work to that of Bridges [1] are shown in Tables

4.11 and 4.12 for the dose to the patient and the dose to the healthcare provider from an externally contaminated patient, respectively. These findings are on the same order of magnitude as the findings determined by Bridges. The discrepancies have to do with the difference in height of the reference male phantom and the difference in the breast structure of the male. Bridges employed the BodyBuilder program to create the reference male phantom MCNP model which resulted in a slightly taller phantom. This would lead to a larger surface area for the phantom causing a larger source to be concentrated on the patient. Bridges used a modified version of the reference female phantom with larger breasts, which increased the surface area of the phantom resulting in larger overall source strength of the patient. The same adipose male phantom was used in both studies which explains the small difference in values for the dose to the patient. For the effective dose to the healthcare provider, a different tally was employed in this study which tallies the electrons and photons at the same time. Bridges' results were obtained using a separate tally for the secondary electrons and the photons. This may 
account for the difference in the effective dose to the healthcare provider. The results from the study preformed by Smith et al. were obtained using point kernel calculations and are in good agreement with the results obtained in this study.

Table 4.11 Comparison of Bridges' Study and the Present Work for Dose to the Patient with 37 $\mathrm{GBq} / \mathrm{m}^{2}$ External Contamination (mSv/hr) [1]

\begin{tabular}{|c|ccccc|}
\hline Patient & ${ }^{60} \mathbf{C o}$ & ${ }^{{ }^{\mathbf{9} 2} \mathbf{I r}}$ & ${ }^{{ }^{\mathbf{2 4 1}} \mathbf{A m}}$ & ${ }^{137} \mathbf{C s}$ & ${ }^{\mathbf{1 3 1}} \mathbf{I}$ \\
\hline \hline Reference Male & & & & & \\
This Study & 204.1 & 88.2 & 2.61 & 62.4 & 41.6 \\
Bridges' Study & 270 & 90.9 & 2.8 & 66.9 & 41.6 \\
\hline Reference Female & & & & & \\
This Study & 174.1 & 77.0 & 2.32 & 55.0 & 24.0 \\
Bridges' Study & 233 & 77.9 & 2.44 & 57.4 & 35.7 \\
\hline Adipose Male & & & & & \\
This Study & 206.1 & 90.8 & 2.94 & 63.1 & 29 \\
Bridges' Study & 219 & 74 & 2.32 & 48 & 30.5 \\
\hline
\end{tabular}

Table 4.12 Comparison of Bridges' Study, Smith et al., and the Present Work for Dose to the Healthcare Provider Due to Patient with $37 \mathrm{GBq} / \mathrm{m}^{2}$ External Contamination (mSv/hr) [1] [8]

\begin{tabular}{|c|c|c|c|c|c|}
\hline Healthcare Provider / Patient & ${ }^{60} \mathrm{Co}$ & ${ }^{192} \mathrm{Ir}$ & ${ }^{241} \mathrm{Am}$ & ${ }^{137} \mathrm{Cs}$ & ${ }^{131} I$ \\
\hline Smith et al. Results (mSv/hr) & 39 & 15 & 0.66 & 10 & -- \\
\hline \multicolumn{6}{|l|}{ Reference Male / Reference Male } \\
\hline This Study (mSv/hr) & 32.1 & 15.7 & 0.4 & 10.6 & 7.5 \\
\hline Bridges' Study (mSv/hr) & 41.9 & 15.3 & 0.49 & 10.7 & 6.99 \\
\hline \multicolumn{6}{|l|}{ Reference Female / Reference Female } \\
\hline This Study (mSv/hr) & 28.5 & 14.1 & 0.4 & 9.6 & 6.8 \\
\hline Bridges' Study (mSv/hr) & 37 & 13.4 & 0.426 & 9.44 & 6.08 \\
\hline \multicolumn{6}{|l|}{ Adipose Male / Adipose Male } \\
\hline This Study (mSv/hr) & 29.8 & 13.9 & 0.3 & 10.5 & 7.6 \\
\hline Bridges' Study (mSv/hr) & 28.2 & 9.32 & 0.275 & 7.04 & 5.03 \\
\hline \multicolumn{6}{|l|}{ Reference Male / Adipose Male } \\
\hline This Study (mSv/hr) & 34.1 & 16.0 & 0.4 & 11.0 & 7.7 \\
\hline Bridges' Study (mSv/hr) & 44.2 & 16.2 & 0.529 & 11.4 & 7.42 \\
\hline
\end{tabular}




\section{CHAPTER 5}

\section{DOSE TO PATIENT}

The effective dose rate to the patient due to external contamination is a concern. Two major factors affect the dose received by the patient: the amount of fat on the patient and the surface area of the patient's skin. More body fat provides more shielding for the radiosensitive internal organs, thus reducing the dose. On the other hand, patients with large skin surface areas have a higher level of total activity on their bodies than the patients with smaller skin surface areas because a uniform distribution was assumed.

\subsection{Reference Male}

The reference male, having a skin surface area of $1.8 \mathrm{~m}^{2}$ and a BMI of 20, contains a total of $66.6 \mathrm{GBq}$ of external contamination assuming a uniform contamination level of $37 \mathrm{GBq} / \mathrm{m}^{2}$. The reference male does not contain a significant amount of body fat to shield his radiosensitive internal organs. The percentage of the effective dose by organ is shown in Figure 5.1. Due to the higher energy photons emitted by ${ }^{60} \mathrm{Co},{ }^{192} \mathrm{Ir},{ }^{137} \mathrm{Cs}$, and ${ }^{131} \mathrm{I}$, the internal organs are not shielded very well. The colon wall yields the largest contribution to effective dose due to its higher weighting factor. The skin has the lowest contribution to effective dose due to its low weighting factor. ${ }^{241} \mathrm{Am}$ follows a somewhat different pattern than the isotopes discussed above. ${ }^{241} \mathrm{Am}$ emits a low energy gamma ray of $59.5 \mathrm{keV}$. The penetrating power of this gamma ray is much smaller then that of the higher energy gamma rays emitted by the other isotopes. Due to 
the weighting factor, the bone dose is the largest contributor to the effective dose. For ${ }^{241} \mathrm{Am}$, the esophagus received both the lowest absorbed dose and the lowest contributor to the effective dose. The effective dose contribution and absorbed dose per organ for each isotope for a contamination level of $37 \mathrm{GBq} / \mathrm{m}^{2}$ for the reference male phantom are shown in Appendix I and $\mathrm{L}$, respectively.

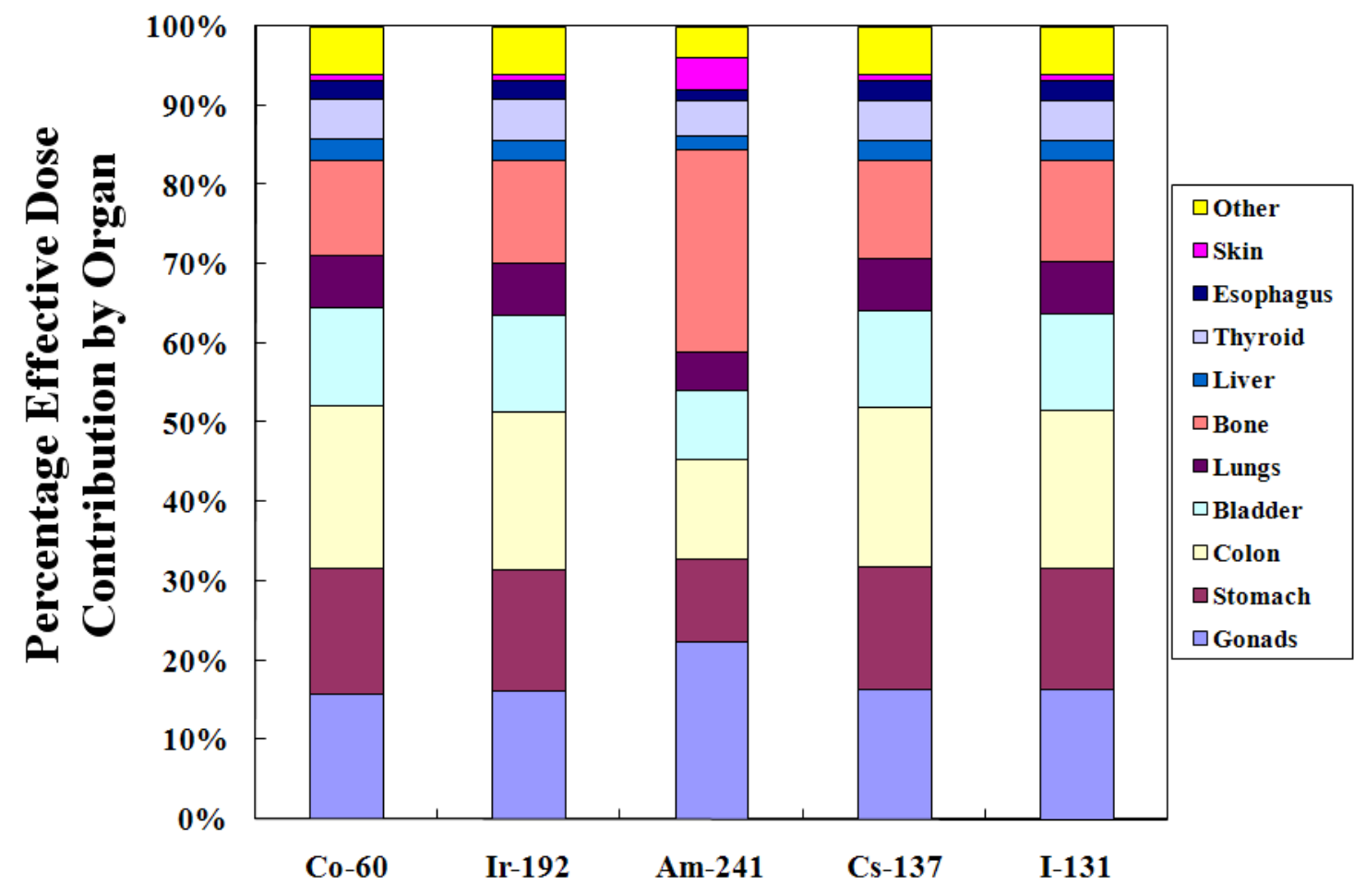

Figure 5.1 The Percentage of the Effective Dose Contributions by Organ for the Reference Male 


\subsection{Reference Female}

The reference female, with a surface area of $1.635 \mathrm{~m}^{2}$ and a BMI of 23, contains 60.5 $\mathrm{GBq}$ of external contamination for a uniform surface contamination of $37 \mathrm{GBq} / \mathrm{m}^{2}$. Similarly to the reference male, the reference female does not have a significant amount of body fat to shield her internal organs. The percentage of the total effective dose contributed by each organ is

dependent on the isotope of contamination. For ${ }^{60} \mathrm{Co},{ }^{192} \mathrm{Ir},{ }^{137} \mathrm{Cs}$ and ${ }^{131} \mathrm{I}$, the penetrating ability of the high-energy gamma rays allows a significant amount of the radiation to reach the internal organs is shown in Figure 5.2. The effective dose contribution and absorbed dose per organ for each isotope for a contamination level of $37 \mathrm{GBq} / \mathrm{m}^{2}$ for the reference female phantom are shown in Appendix I and L, respectively..

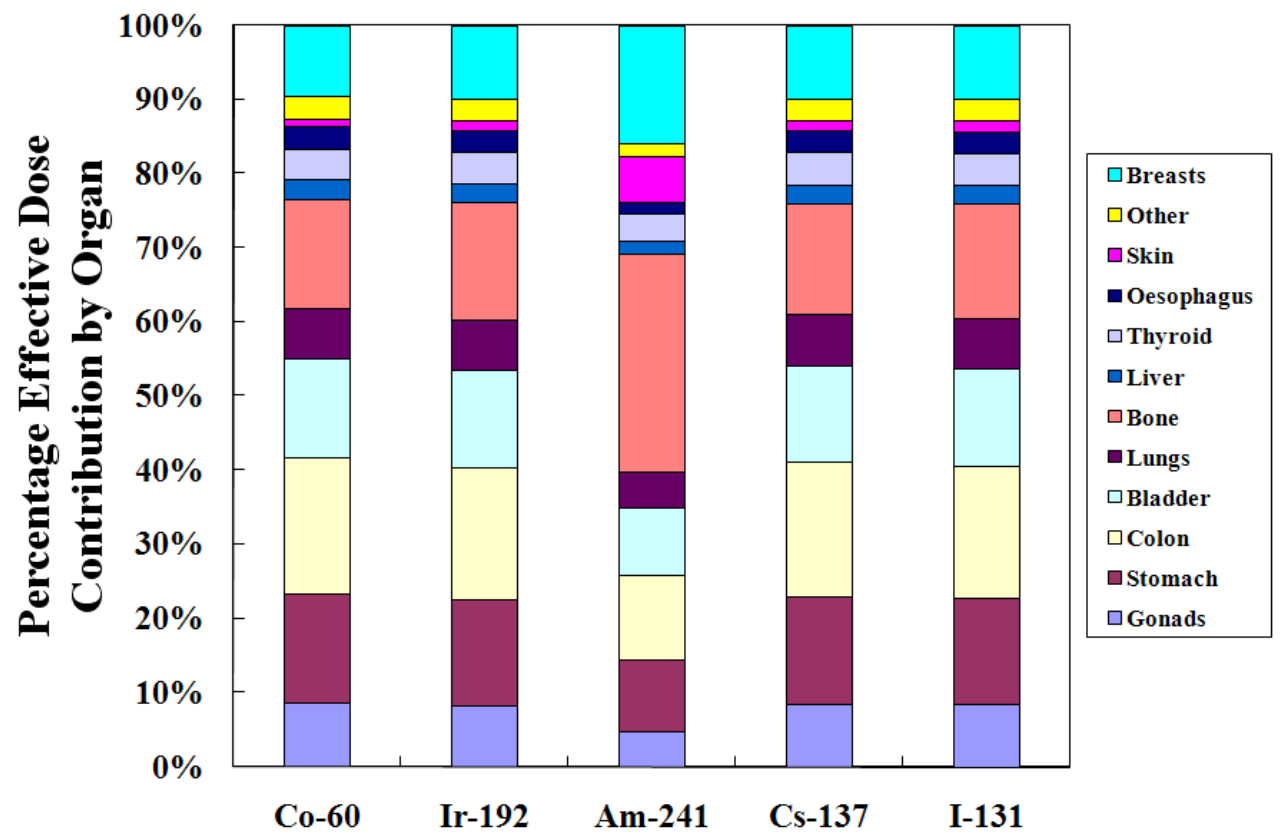

Figure 5.2 The Percentage of the Effective Dose Contributions by Organ for the Reference Female 


\subsection{Adipose Male}

The adipose male has a BMI of 30 and contains $22 \mathrm{~kg}$ of interstitial adipose tissue, which provides some shielding for his internal organs. The surface area of his body is $2.52 \mathrm{~m}^{2}$, which is significantly large than the reference male and results in $93.24 \mathrm{GBq}$ of total external contamination for the $37 \mathrm{GBq} / \mathrm{m}^{2}$ uniform surface contamination. The interstitial adipose tissue provided a large amount of shielding for most of the organs in the abdomen region and reduces the absorbed dose to the liver so that it is the lowest absorbed dose of all organs for all isotopes. Although the bladder is in the abdomen region, it is located more towards the back of the individual. For the more penetrating radiation emitted by ${ }^{60} \mathrm{Co},{ }^{192} \mathrm{Ir},{ }^{137} \mathrm{Cs}$ and ${ }^{131} \mathrm{I}$, the adipose tissue did not provide effective shielding of the bladder, causing it to receive the largest absorbed dose. Similar to the reference male and female, the skin was the lowest contributor to the effective dose for the more penetrating radiation emitted by ${ }^{60} \mathrm{Co},{ }^{192} \mathrm{Ir},{ }^{137} \mathrm{Cs}$ and ${ }^{131} \mathrm{I}$. For ${ }^{241} \mathrm{Am}$, the skin made the largest contribution to the effective dose due to the lower penetration power of the gamma ray emitted, and the lowest contributor to the effective dose rate was for the liver. Due to the fact that the male gonads are located on the outside of the body and the interstitial adipose tissue allows the gonads to see more body surface area, the gonads received the highest contribution to the effective dose rate for all isotopes. 


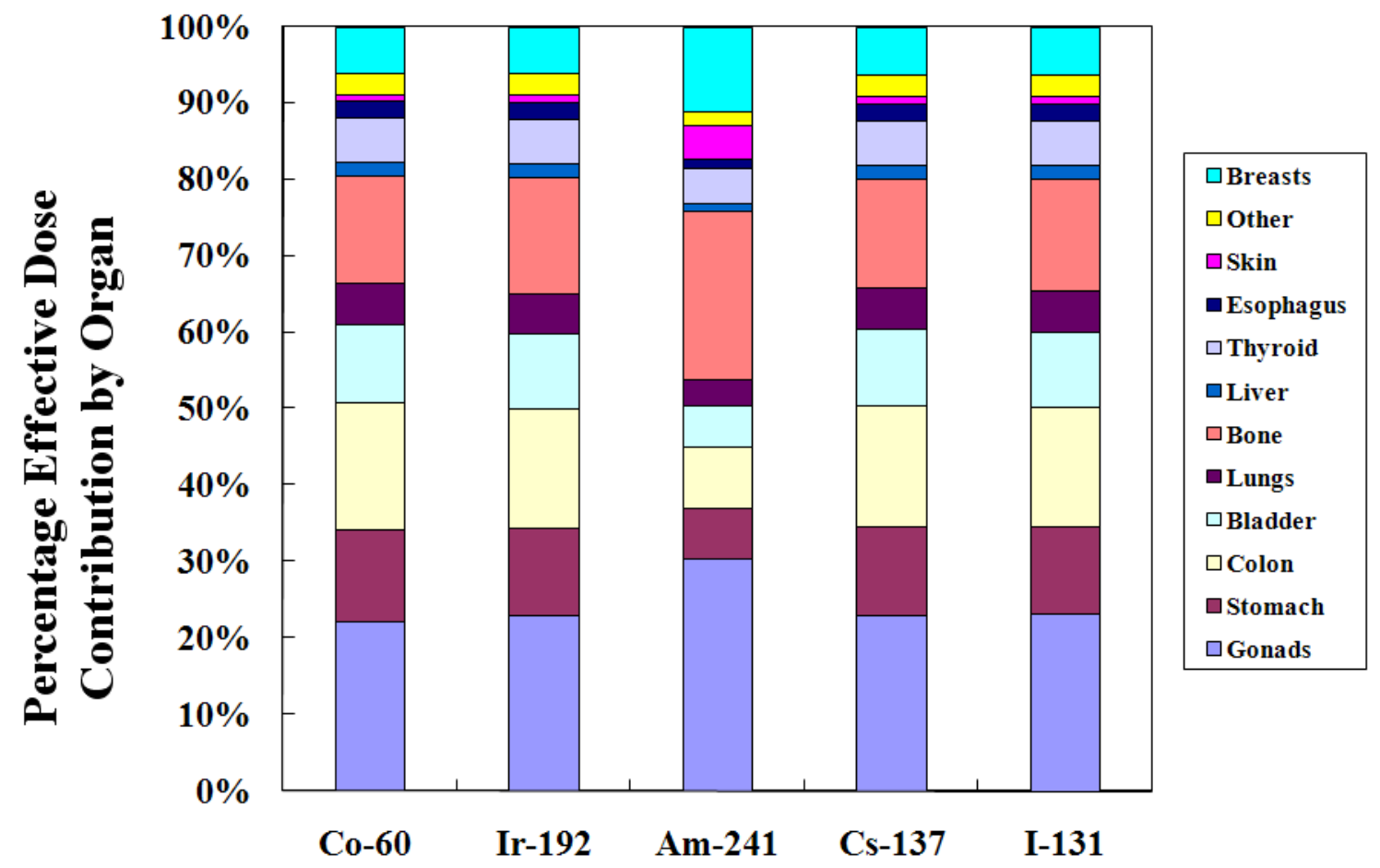

Figure 5.3 The Percentage of the Effective Dose Contributions by Organ for the Adipose Male

\subsection{Adipose Female}

The adipose female has a total external contamination of $74.481 \mathrm{GBq}$ due to the 37 $\mathrm{GBq} / \mathrm{m}^{2}$ surface contamination level since it has a surface area of $2.013 \mathrm{~m}^{2}$. The adipose female contains $15 \mathrm{~kg}$ of subcutaneous adipose tissue distributed on the torso, breasts, abdomen, and legs. The increased breast volume causes the breasts to have the highest organ absorbed dose. The distribution of adipose tissue around the torso increases the amount of shielding to organs, such as the bladder, but decreases the amount of shielding provided to the organs in the abdomen area when compared to the adipose male and postmenopausal adipose female. For ${ }^{60} \mathrm{Co},{ }^{192} \mathrm{Ir}$, ${ }^{137} \mathrm{Cs}$ and ${ }^{131} \mathrm{I}$, the colon wall yielded the highest contribution to the effective dose for the adipose 
female due to the increased surface area around the abdomen. Similar to the reference female, the ovaries received the lowest organ absorbed dose due to their internal location. Due to the small weighting factor for skin, the skin again yields the smallest effective dose rate. For ${ }^{241} \mathrm{Am}$, the skin and bones received the maximum absorbed dose and the highest contribution to the effective dose, respectively, and the gonads and the liver received the minimum absorbed dose and the lowest contribution to the effective dose, respectively.

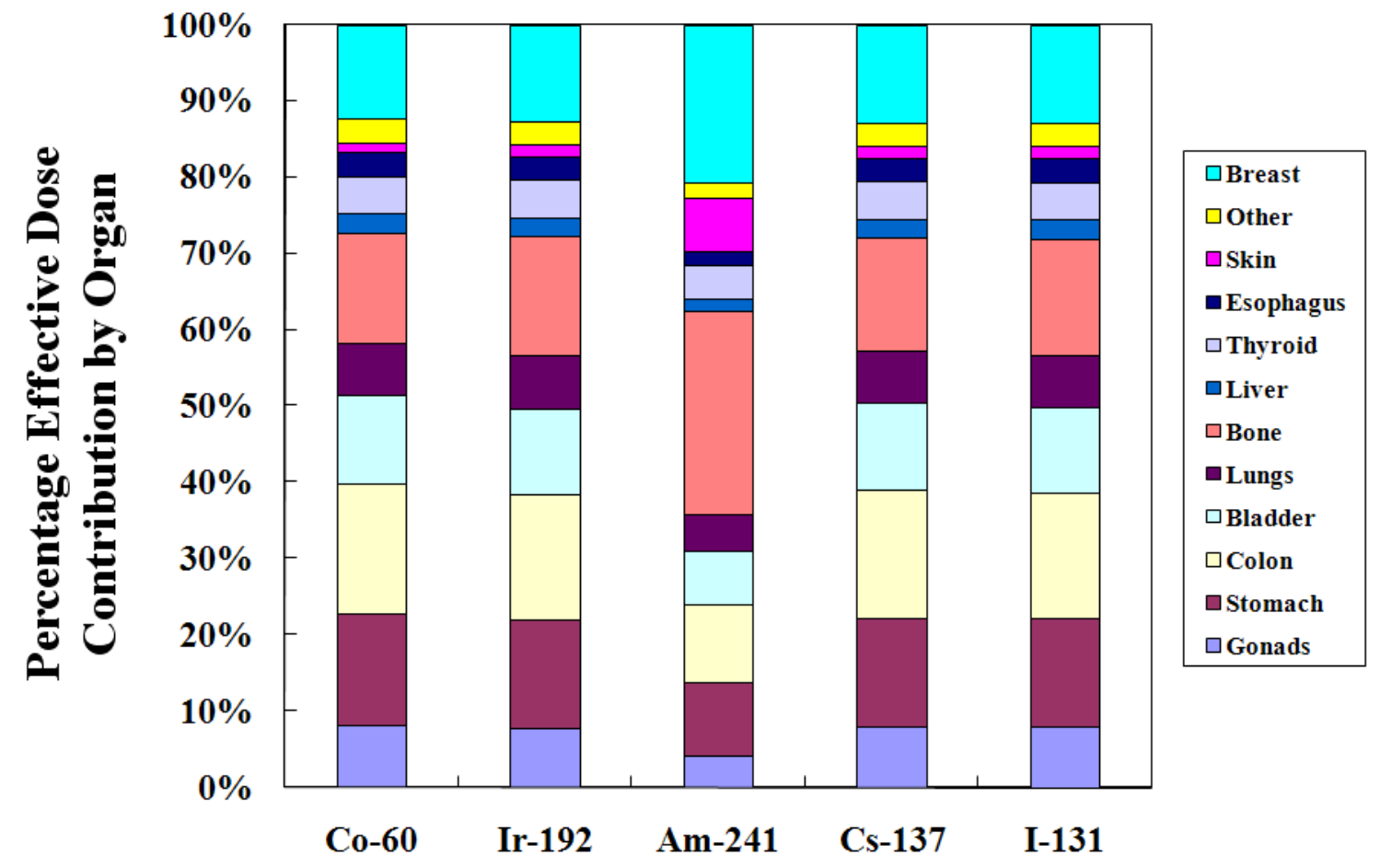

Figure 5.4 The Percentage of the Effective Dose Contributions by Organ for the Adipose Female 


\subsection{Postmenopausal Adipose Female}

The postmenopausal adipose female contains an additional $27 \mathrm{~kg}$ of interstitial adipose tissue and has maximum contamination level of $79.476 \mathrm{GBq}$. The large amount of interstitial adipose tissue proves significant shielding for her internal organs in the abdomen area. For the more penetrating radiation emitted from ${ }^{60} \mathrm{Co},{ }^{192} \mathrm{Ir},{ }^{137} \mathrm{Cs}$ and ${ }^{131} \mathrm{I}$, the breasts received the largest absorbed dose. The highest contribution to the effective dose is approximately equal for the postmenopausal adipose female: the gonads, the bone and the colon wall. The bladder, which was well shielded by the adipose tissue, received the smallest absorbed dose, and the skin again contributed the least to the effective dose. For ${ }^{241} \mathrm{Am}$, the results are similar to the adipose female except that the liver was not only the lowest contributor to the effective dose but has the smallest absorbed dose.

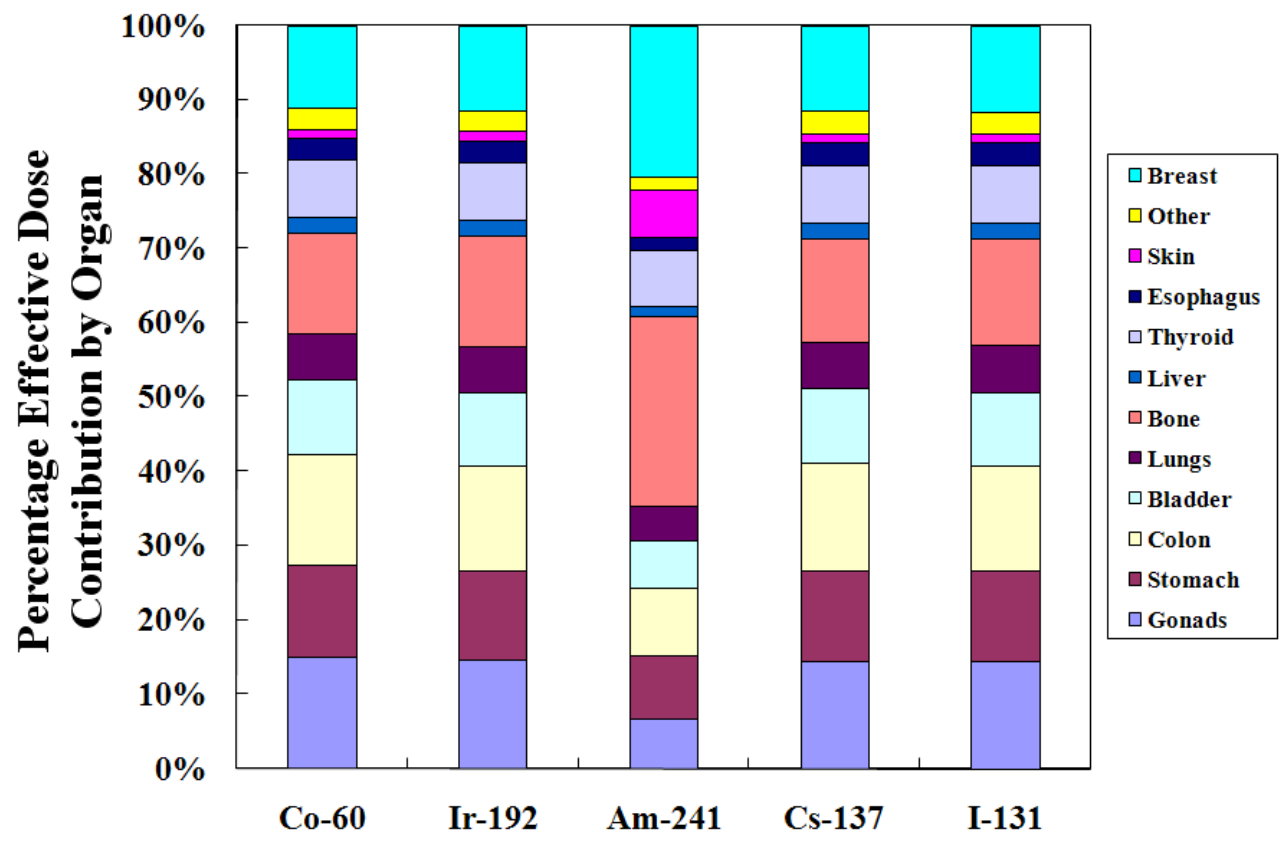

Figure 5.5 The Percentage of the Effective Dose Contributions by Organ for the Postmenopausal Adipose Female 


\subsection{Comparisons of Dose to Body Type}

For all of the anthropomorphic phantoms considered, ${ }^{60} \mathrm{Co}$ produces the highest effective dose rate due to its two high energy gamma-rays. ${ }^{241}$ Am results in the lowest effective dose rate due to its low energy gamma-ray emission. The dose rates due to the other isotopes are a function of energy and intensity of the gamma rays. ${ }^{137} \mathrm{Cs}$ has the second highest gamma ray energy and produces the second highest effective dose rate to the patient. ${ }^{131}$ I emits gamma rays at energies higher than those emitted by ${ }^{192} \mathrm{Ir}$, but not with as high of an intensity, giving ${ }^{131}$ I the second lowest average effective dose rate. The dose to the patient for each isotope in addition to the average effective dose due to an isotope and the standard deviation is shown in Table 5.1.

Table 5.1 Dose to Patient from $37 \mathrm{GBq} / \mathrm{m}^{2}$ Body Surface Contamination (mSv/hr)

\begin{tabular}{|l|c|c|c|c|c|}
\hline Patient & ${ }^{\mathbf{6 0}} \mathbf{C o}$ & ${ }^{\mathbf{1 9 2}} \mathbf{I r}$ & ${ }^{\mathbf{2 4 1}} \mathbf{A m}$ & ${ }^{\mathbf{1 3 7}} \mathbf{C s}$ & ${ }^{\mathbf{1 3 1}} \mathbf{I}$ \\
\hline \hline Reference Male & $197 \pm 0.66$ & $75.5 \pm 0.38$ & $2.61 \pm 0.03$ & $48.6 \pm 0.15$ & $28.2 \pm 0.08$ \\
\hline Reference Female & $167 \pm 0.69$ & $64.3 \pm 0.25$ & $2.32 \pm 0.01$ & $41.2 \pm 0.16$ & $24 \pm 0.09$ \\
\hline Adipose Male & $199 \pm 0.65$ & $78.1 \pm 0.14$ & $2.94 \pm 0.02$ & $49.3 \pm 0.31$ & $29 \pm 0.17$ \\
\hline Adipose Female & $173 \pm 0.56$ & $67 \pm 0.15$ & $2.3 \pm 0.02$ & $42.6 \pm 0.33$ & $24.9 \pm 0.12$ \\
\hline $\begin{array}{l}\text { Postmenopausal } \\
\text { Adipose Female }\end{array}$ & $181 \pm 1.02$ & $70.3 \pm 0.30$ & $2.29 \pm 0.03$ & $44.3 \pm 0.48$ & $26 \pm 0.26$ \\
\hline \hline Average & 183.4 & 71.0 & 2.5 & 45.2 & 26.4 \\
\hline \hline Standard Deviation & 14.2 & 5.7 & 0.3 & 3.6 & 2.1 \\
\hline
\end{tabular}

For all of the isotopes except ${ }^{241} \mathrm{Am}$, there is a distinct pattern for the effective dose rate as a function of body type. The adipose male, who has the largest total contamination due to his body surface area, receives the highest dose. The reference male receives the second highest 
dose. The doses to the male anthropomorphic phantoms are significantly higher than the doses received by the female phantoms due to the location of the male gonads. The reference female receives the smallest effective dose rate due to the external contamination, and the effective dose rate increases as a function of skin surface area for the female anthropomorphic phantoms. This shows that for the more penetrating radiation, the additional body fat does not compensate for the additional contamination due to a larger surface area for the adipose patient. The dose to each organ as a function of body type for ${ }^{60} \mathrm{Co}$ is depicted in Figure 5.6.

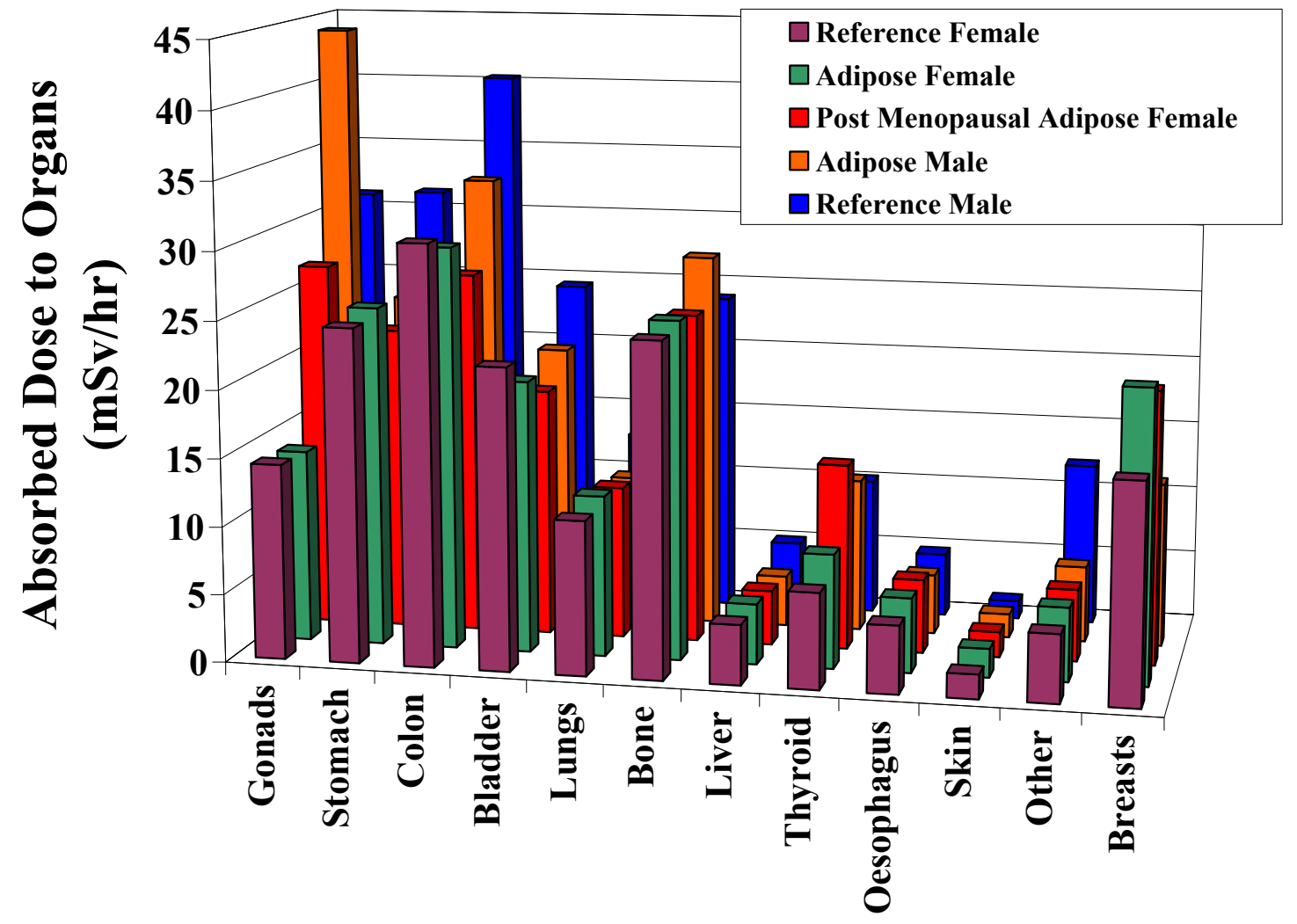

Figure 5.6 Absorbed Dose for Each Anthropomorphic Phantom $37 \mathrm{GBq} / \mathrm{m}^{2}$ External Contamination of ${ }^{60} \mathrm{Co}(\mathrm{mSv} / \mathrm{hr})$ 
The pattern of dose as a function of body type of the patient is slightly different due to the low energy of the photon emitted by ${ }^{241} \mathrm{Am}$. The male anthropomorphic phantoms again have higher effective dose then the female phantoms. The adipose male has the highest effective dose rate because the curvature of the stomach directs more radiation towards the gonads. The female dose rate actually deceases with increasing BMI. This is due to the ability of the adipose tissue to shield the radiosensitive organs on the female phantoms. The dose to each organ for ${ }^{241} \mathrm{Am}$ as a function of body type is shown in Figure 5.7. The amount of time an individual can be contaminated with $37 \mathrm{GBq} / \mathrm{m}^{2}$ of external contamination before receiving $250 \mathrm{mSv}$ of dose is shown in Table 5.2.

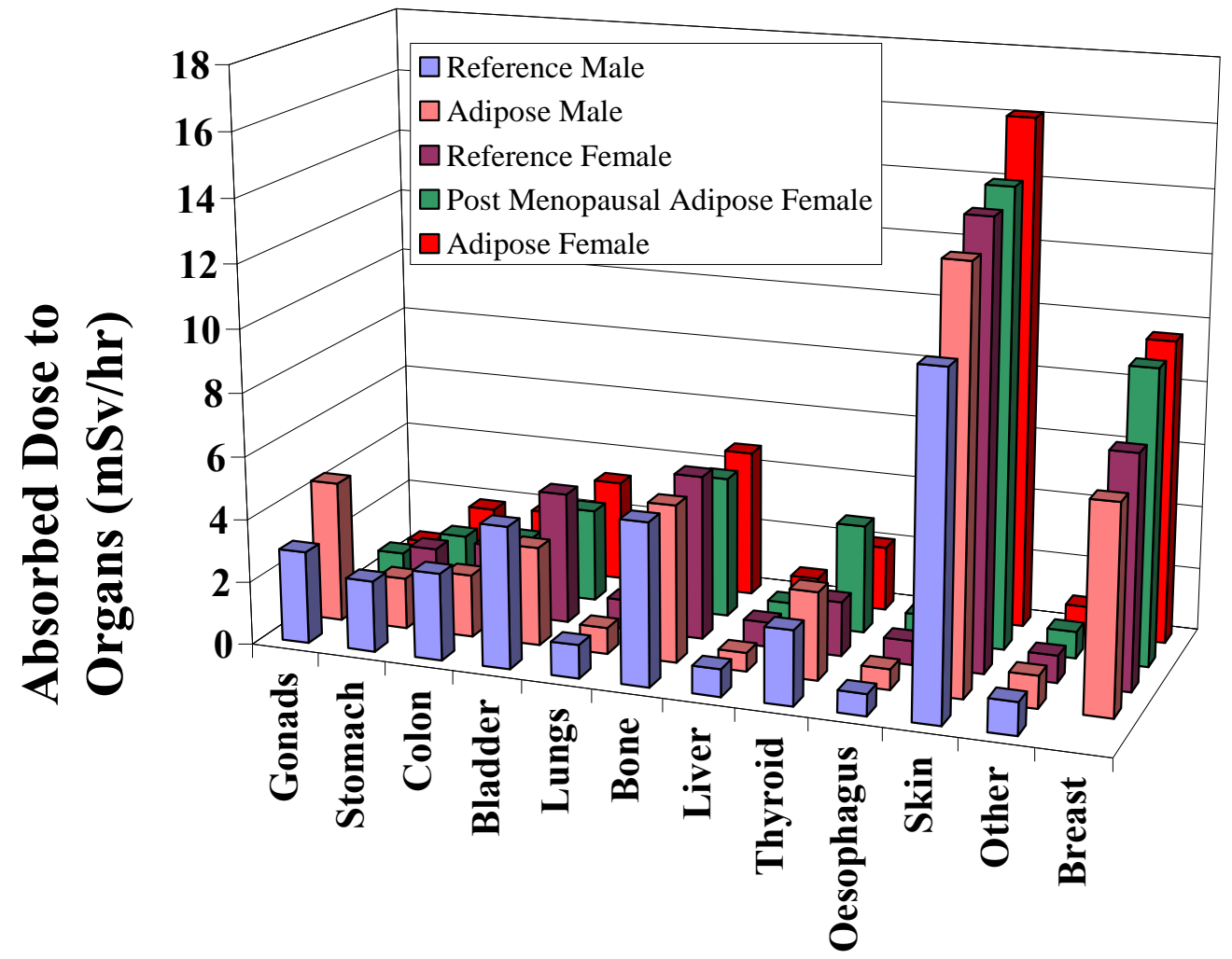

Figure 5.7 Absorbed Dose for Each Anthropomorphic Phantom $37 \mathrm{GBq} / \mathrm{m}^{2}$ External Contamination of ${ }^{241} \mathrm{Am}(\mathrm{mSv} / \mathrm{hr})$ 
Table 5.2 Time (Hours) Before an Individual with $37 \mathrm{GBq} / \mathrm{m}^{2}$ of External Contamination Receives $250 \mathrm{mSv}$ Dose from Gamma Dose

\begin{tabular}{|c|c|c|c|c|c|}
\hline Patient & ${ }^{60} \mathrm{Co}$ & ${ }^{192} \mathrm{Ir}$ & ${ }^{241} \mathrm{Am}$ & ${ }^{137} \mathrm{Cs}$ & ${ }^{131} \mathbf{I}$ \\
\hline Reference Male & 1.27 & 3.31 & 95.79 & 5.14 & 8.87 \\
\hline Reference Female & 1.50 & 3.89 & 107.76 & 6.07 & 10.42 \\
\hline Adipose Male & 1.26 & 3.20 & 85.03 & 5.07 & 8.62 \\
\hline Adipose Female & 1.45 & 3.73 & 108.70 & 5.87 & 10.04 \\
\hline Postmenopausal Adipose Female & 1.38 & 3.56 & 109.17 & 5.64 & 9.62 \\
\hline Average & 1.36 & 3.52 & 100.00 & 5.53 & 9.47 \\
\hline Standard Deviation & 0.11 & 0.29 & 10.65 & 0.44 & 0.76 \\
\hline
\end{tabular}

\subsection{Beta Dose to Patient}

The beta dose to the patient was determined by assuming that all of the energy of the beta particles was deposited in the skin of the patient. The absorbed dose is found by dividing the energy emitted per disintegration by the mass of the skin and multiplying by the source strength with is proportional to the surface area of the phantom. Since the thickness of the skin for all phantoms is constant, the absorbed dose is the same for all the phantoms for a given isotope. The absorbed dose and the contribution to the effective dose are shown in Table 5.3.

Table 5.3 Absorbed Dose and Contribution to Effective Dose from Betas to the Patient's Skin

\begin{tabular}{|l|r|r|r|r|}
\hline Patient & \multicolumn{1}{c|}{${ }^{\mathbf{6 0}} \mathbf{C o}$} & \multicolumn{1}{c|}{${ }^{192} \mathbf{I r}$} & \multicolumn{1}{|c|}{${ }^{\mathbf{1 3 7}} \mathbf{C s}$} & \multicolumn{1}{c|}{${ }^{\mathbf{1 3 1}} \mathbf{I}$} \\
\hline \hline Absorbed Dose (mGy/hr) & 710.7 & 1265.7 & 1381.4 & 1342.1 \\
\hline Contribution to Effective Dose (mSv/hr) & 7.1 & 12.7 & 13.8 & 13.4 \\
\hline
\end{tabular}


The total dose to the patient was increased by the addition of the beta dose to the skin.

The total dose to the patient and the time it would take for the patient to receive the $250 \mathrm{mSv}$ dose are shown in Tables 5.4 and 5.5.

Table 5.4 Effective Dose to Patient From Gammas and Betas for $37 \mathrm{Gq} / \mathrm{m}^{2}$ External Contamination $(\mathrm{mSv} / \mathrm{hr})$

\begin{tabular}{|l|c|r|r|r|}
\hline Patient & ${ }^{\mathbf{6 0}} \mathbf{C o}$ & \multicolumn{1}{c|}{${ }^{192} \mathbf{I r}$} & \multicolumn{1}{c|}{${ }^{\mathbf{1 3 7}} \mathbf{C s}$} & \multicolumn{1}{c|}{${ }^{\mathbf{1 3 1}} \mathbf{I}$} \\
\hline \hline Reference Male & 204.1 & 88.2 & 62.4 & 41.6 \\
\hline Reference Female & 174.1 & 77.0 & 55.0 & 24.0 \\
\hline Adipose Male & 206.1 & 90.8 & 63.1 & 29.0 \\
\hline Adipose Female & 180.1 & 79.7 & 56.4 & 24.9 \\
\hline Postmenopausal Adipose Female & 188.1 & 83.0 & 58.1 & 26.0 \\
\hline
\end{tabular}

5.5 Time in Hours it Takes the Patient to Receive 250mSv Effective Dose

\begin{tabular}{|l|r|r|r|r|}
\hline Patient & \multicolumn{1}{|c|}{${ }^{\mathbf{6 0}} \mathbf{C o}$} & \multicolumn{1}{c|}{${ }^{192} \mathbf{I r}$} & \multicolumn{1}{c|}{${ }^{\mathbf{1 3 7}} \mathbf{C s}$} & \multicolumn{1}{c|}{${ }^{\mathbf{1 3 1}} \mathbf{I}$} \\
\hline \hline Reference Male & 1.2 & 2.8 & 4.0 & 6.0 \\
\hline Reference Female & 1.4 & 3.2 & 4.5 & 10.4 \\
\hline Adipose Male & 1.2 & 2.8 & 4.0 & 8.6 \\
\hline Adipose Female & 1.4 & 3.1 & 4.4 & 10.0 \\
\hline Postmenopausal Adipose Female & 1.3 & 3.0 & 4.3 & 9.6 \\
\hline \hline Average & 1.3 & 3.0 & 4.2 & 8.9 \\
\hline \hline Standard Deviation & 0.10 & 0.21 & 0.26 & 1.77 \\
\hline
\end{tabular}




\section{CHAPTER 6}

\section{CONCLUSIONS}

It is important for the healthcare industry to understand the dose rates associated with attending to both internally and externally contaminated patients and consider the amount of time required to perform a lifesaving procedure. A healthcare provider can attend to a patient that is contaminated with $37 \mathrm{GBq} / \mathrm{m}^{2}$ of ${ }^{60} \mathrm{Co}$ is 1.6 hours before receiving the $50 \mathrm{mSv}$. It would take 8.3 hours for the healthcare provider to receive the EPA limit of $250 \mathrm{mSv}$ lifesaving dose. The externally contaminated patient would receive $1694 \mathrm{mSv}$ in 8.3 hours. The removal of the clothes from the externally contaminated patient will remove approximately $90 \%$ of the contamination, reducing the dose to both the patient and the healthcare provider. For internally contaminated patients, the effective doses to the healthcare provider are lower. For a patient internally contaminated after a 1 ALI intake of ${ }^{192}$ Ir assuming a fast inhalation class, the healthcare provider would receive a dose rate of $3.7 \mu \mathrm{Sv} / \mathrm{hour}$.

The possibility of the patient having radioactive shrapnel which may need to be surgically removed would be an additional scenario of concern to the healthcare industry. The shrapnel may range in activity from 37 to $3700 \mathrm{GBq}$. This scenario should be considered in future work. 


\section{APPENDIX A \\ COMPOSITION OF SURGICAL TABLE}

Table A.1 Composition of Polyurethane Foam [7]
\begin{tabular}{|c|c|}
\hline Polyurethane & $\begin{array}{c}\text { Weight } \\
\text { Percent }\end{array}$ \\
\hline \hline $\mathrm{H}$ & 8.874 \\
\hline $\mathrm{C}$ & 64.056 \\
\hline $\mathrm{N}$ & 3.401 \\
\hline $\mathrm{O}$ & 23.629 \\
\hline $\mathrm{Cl}$ & 0.04 \\
\hline
\end{tabular}

Table A.2 Composition of Grade 304 Stainless Steel [9]

\begin{tabular}{|c|c|}
\hline Material & $\begin{array}{c}\text { Weight } \\
\text { Percent }\end{array}$ \\
\hline \hline $\mathrm{Fe}$ & 65.845 \\
\hline $\mathrm{C}$ & 0.08 \\
\hline $\mathrm{Cr}$ & 20 \\
\hline $\mathrm{Ni}$ & 11 \\
\hline $\mathrm{Mn}$ & 2 \\
\hline $\mathrm{Si}$ & 1 \\
\hline $\mathrm{P}$ & 0.045 \\
\hline $\mathrm{S}$ & 0.03 \\
\hline
\end{tabular}




\section{APPENDIX B}

\section{MASS OF EACH COMPARTMENT OF PHANTOMS}

Table B.1 Mass of Compartments of Anthropomorphic Phantoms in Grams [2]

\begin{tabular}{|c|c|c|c|c|c|}
\hline Compartment & $\begin{array}{c}\text { Reference } \\
\text { Male }\end{array}$ & $\begin{array}{c}\text { Reference } \\
\text { Female }\end{array}$ & $\begin{array}{c}\text { Adipose } \\
\text { Male }\end{array}$ & $\begin{array}{c}\text { Adipose } \\
\text { Female }\end{array}$ & $\begin{array}{c}\text { Postmenopausal } \\
\text { Adipose Female }\end{array}$ \\
\hline \hline Gonads & 34.66 & 10.71 & 34.66 & 10.71 & 5 \\
\hline Stomach & 150 & 140 & 150 & 140 & 140 \\
\hline Ascending Colon & 90 & 90 & 90 & 90 & 90 \\
\hline Sigmoid Colon & 70 & 70 & 70 & 70 & 70 \\
\hline Transverse Colon & 120 & 110 & 120 & 110 & 110 \\
\hline Descending Colon & 90 & 90 & 90 & 90 & 90 \\
\hline Bladder & 45 & 45 & 45 & 45 & 45 \\
\hline Lungs & 1000 & 800 & 1000 & 800 & 800 \\
\hline Bone & 5500 & 4500 & 5500 & 4500 & 4500 \\
\hline Liver & 1820 & 1440 & 1820 & 1440 & 1430 \\
\hline Thyroid & 20.5 & 20.5 & 20.5 & 20.5 & 13.4 \\
\hline Esophagus & 40 & 30 & 40 & 30 & 30 \\
\hline Skin & 2600 & 1790 & 3640 & 2002 & 2352 \\
\hline Other & 3053.5 & 2681.5 & 3308.5 & 2681.5 & 2684 \\
\hline Breasts & 0 & 280 & 280 & 400 & 400 \\
\hline
\end{tabular}




\section{APPENDIX C}

\section{REFENCE MALE INPUT FILE}

Neutron \& Induced Photon Flux Calculations in MIRD Phantom: Oes \& Colon Wall

C Co-60 Skin Source

$1 \quad 1-.001293 \quad-1$ (607:-37:606) (-606:601:35) (600:-35) \&

$(-615: 37:-43: 44: 4:-616)(37:-608: 609) \&$

(37:-608:610) IMP:P=1 IMP:E=1

$22-0.2958 \quad((-2-43):(-24)) 5$ IMP:P=1 IMP:E=1 VOL=9.89817E3 \$ left lung

$3 \quad 3-0.9869-751-6(-8: 32) 84101$ \#2 \#24 \#28 \#58 \#59 \#62 \#700 \&

(113:115) (114:115) IMP:P=1 IMP:E=1 VOL=5.12539E4 \$ torso insd ribs/lvrtop-shldr

$4 \quad 3-0.9869 \quad-78-32117113114$ \#15 \#16 \#17 \#18 \#19 \&

(-4:-9:116:118:-119) (-4:-9:116:120:-121) \&

\#20 \#700 IMP:P=1 IMP:E=1 VOL=7.01171E3 \$ torso

$5 \quad 3-0.9869-78-11751113114 \# 9 \# 13 \# 14 \&$

\#700 IMP:P=1 IMP:E=1 VOL=4.12839E3 \$ torso

$6 \quad 3-0.9869-750-51568496105106113114$ \#10 \#11 \#12 \#27 \& \#32 \#43 \#44 \#47 \#700 IMP:P=1 IMP:E=1 VOL=3.75367E4 \$ torso

$7 \quad 3-0.9869 \quad-797-50$ (83:-86:87:-88) 113114 \#30 \#33 \#38 \#39 \& \#63 \#64 \#65 \#700 IMP:P=1 IMP:E=1 VOL=4.1204E4 \$ torso abdoman

$8 \quad 3-0.9869 \quad-737-9795113114$ \#31 \#33 \#38 \#65 \#66 \& \#700 IMP:P=1 IMP:E=1 VOL=3.96266E4

$94-1.48628-95-10$ IMP:P=1 IMP:E=1 VOL=3.42E2

$104-1.48628-911-12$ IMP:P=1 IMP:E=1 VOL=3.42E2

$114-1.48628$-9 13-14 IMP:P=1 IMP:E=1 VOL=3.42E2

$124-1.48628-915-16$ IMP:P=1 IMP:E=1 VOL=3.42E2

$134-1.48628-917-18$ IMP:P=1 IMP:E=1 VOL=3.42E2

$14 \quad 4-1.48628-919-20$ IMP:P=1 IMP:E=1 VOL=3.42E2

$154-1.48628-921-22$ IMP:P=1 IMP:E=1 VOL=3.42E2

$164-1.48628-923-24$ IMP:P=1 IMP:E=1 VOL=3.42E2

$17 \quad 4-1.4862$

$18 \quad 4-1.4862$

$19 \quad 4-1.4862$

$20 \quad 4-1.4862$

$21 \quad 3-0.9869$

8 -9 25 -26 IMP:P=1 IMP:E=1 VOL=3.42E2 \$ rib

8 -9 27 -28 IMP:P=1 IMP:E=1 VOL=3.42E2 \$ rib

8 -9 29 -30 IMP:P=1 IMP:E=1 VOL=3.42E2 \$ rib

8 -9 31 -32 IMP:P=1 IMP:E=1 VOL=3.42E2 \$ rib

\#37 \#60 \#61 \#62 \#700 IMP:P=1 IMP:E=1 VOL=1.09049E4 \$ head

$223-0.9869 \quad-3738$-39 103 \#700 IMP:P=1 IMP:E=1 VOL=5.26806E4 \$ left leg

$23 \quad 3-0.9869-3738-40104$ \#22 \#700 IMP:P=1 IMP:E=1 VOL=5.26806E4 \$ right leg

242 -0.2958 ((-41 -4 42):(-41 4)) 5 IMP:P=1 IMP:E=1 VOL=9.87788E3 \$ right lung

$25 \quad 3-0.9869 \quad 715-3743-44-471639407273 \# 700 \&$

\#600 IMP:P=1 IMP:E=1 VOL=8.35231E2 \$ genitalia

$263-0.9869-47$ IMP:P=1 IMP:E=1 VOL=8.24983E3 \$ brain

$273-0.986950-51-48-49$ \#10 \#11 \#12 IMP:P=1 IMP:E=1 VOL=1.085E4 \$ liver

$283-0.9869 \quad(-5254):(-53-54$ 55) IMP:P=1 IMP:E=1 VOL=3.48665E3 \$ heart

293 -0.9869 -56 IMP:P=1 IMP:E=1 VOL=2.39203E3 \$ stomach

$303-0.9869 \quad 138$-57 58 -59 IMP:P=1 IMP:E=1 VOL=5.46974E2 \$ Ascending Colon Wall

$31 \quad 3-0.9869 \quad(-6314165-61):(-6414237-65) \&$

IMP:P=1 IMP:E=1 VOL=4.19631E2 \$ Sigmoid Colon Wall

$323-0.9869-6213966-67$ 59 IMP:P=1 IMP:E=1 VOL=7.21861E2 \$ Transverse Colon Wall

33 3-0.9869 -60 14061 -59 -83 IMP:P=1 IMP:E=1 VOL=5.2306E2 \$ Descending Colon Wall

35 -0.9869 -72 IMP:P=1 IMP:E=1 VOL=1.11E2 \$ testicle 


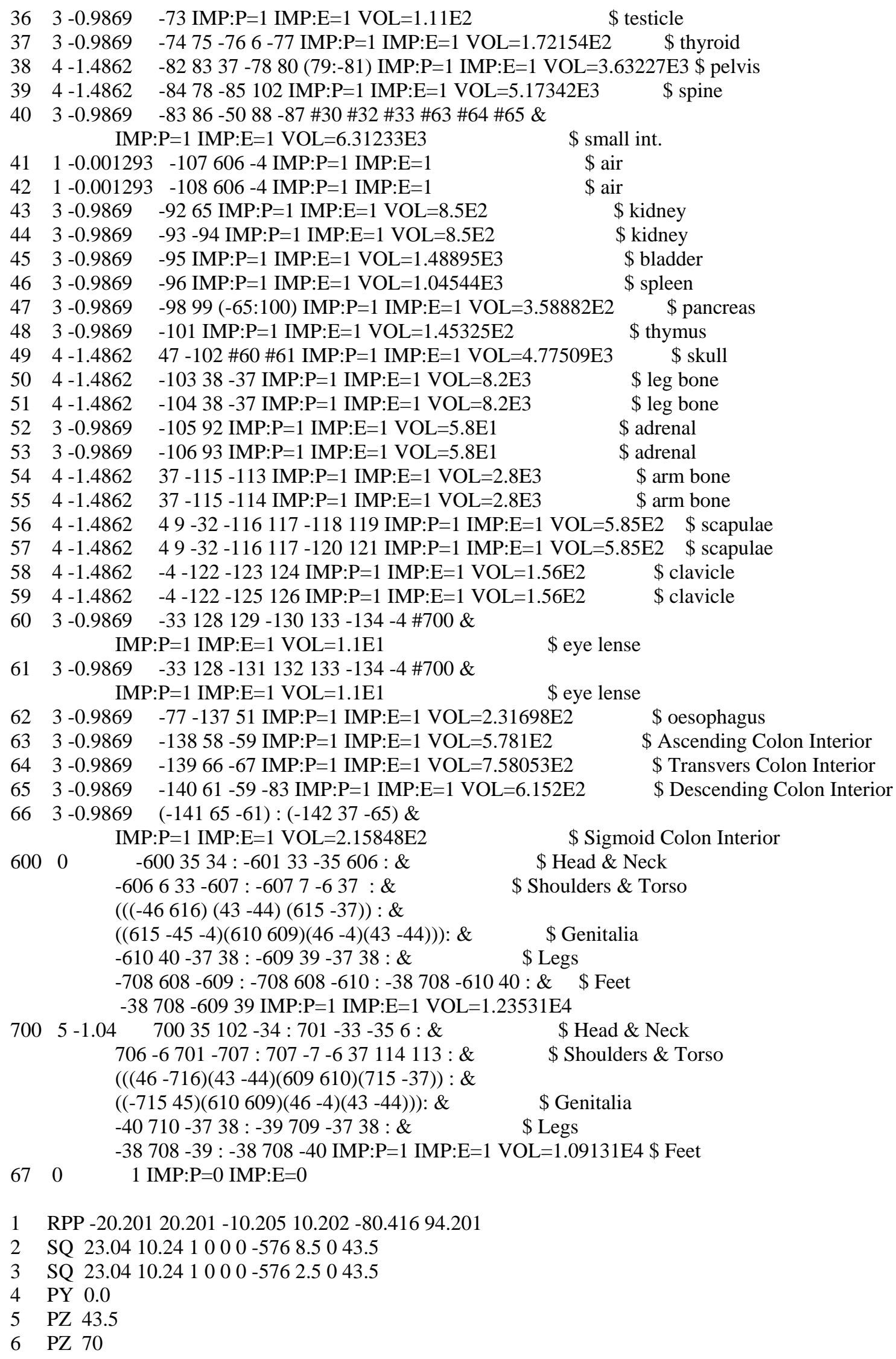


706 PZ 69.8

606 PZ 70.2

7 SQ $14.00000-400.0000$

707 SQ $0.0025510 .01041200000-10000$

607 SQ $0.0024510 .0096100000-1000$

8 SQ $13.150000-272.250000$

9 SQ $13.0100000-289.00000$

10 PZ 44.9

11 PZ 35.1

$12 \quad$ PZ 36.5

13 PZ 37.9

14 PZ 39.3

$15 \quad$ PZ 40.7

16 PZ 42.1

$17 \quad$ PZ 46.3

$18 \quad$ PZ 47.7

19 PZ 49.1

20 PZ 50.5

$21 \quad$ PZ 51.9

22 PZ 53.3

23 PZ 54.7

24 PZ 56.1

25 PZ 57.5

26 PZ 58.9

27 PZ 60.3

28 PZ 61.7

29 PZ 63.1

$30 \quad$ PZ 64.5

$31 \quad$ PZ 65.9

32 PZ 67.3

33 SQ $1004900000-4900000$

701 SQ $0.0216260 .010412000000-10000$

601 SQ $0.019290 .00961200000-10000$

34 SQ $72253540.2549000000-35402500085.5$

700 SQ $0.0216260 .0104120 .0145160000-10085.5$

600 SQ $0.019290 .0096120 .0132120000-10085.5$

35 PZ 85.5

36 PZ 94

37 PZ 0

38 PZ -80

708 PZ -80.215

608 PZ -80.415

39601 GQ 5.025 $5000-1-100000$

709603 GQ $5.055000-1-100000$

609605 GQ $4.9635000-1-100000$

40600 GQ 5.02550001100000

710602 GQ 5.08950001100000

610604 GQ 4.96350001100000

41 SQ $23.0410 .2410000-576-8.5043 .5$

42 SQ $23.0410 .2410000-576-2.5043 .5$

43 P $100101-100$

44 P $100-1 \quad 100$

45 PZ -4.8

715 PZ -4.6

615 PZ -5.0

$46 \quad \mathrm{P} \quad 0 \quad 101-100$ 


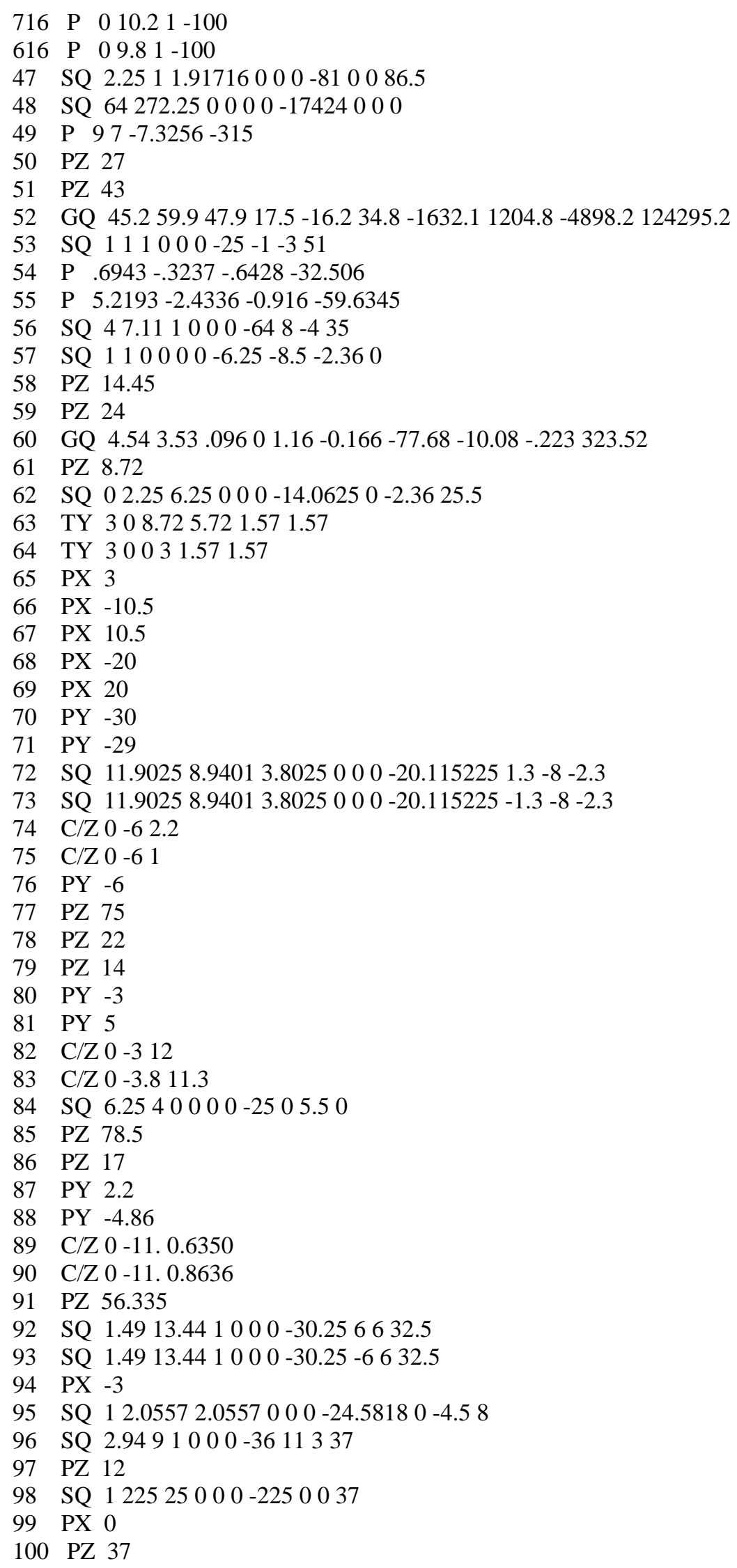




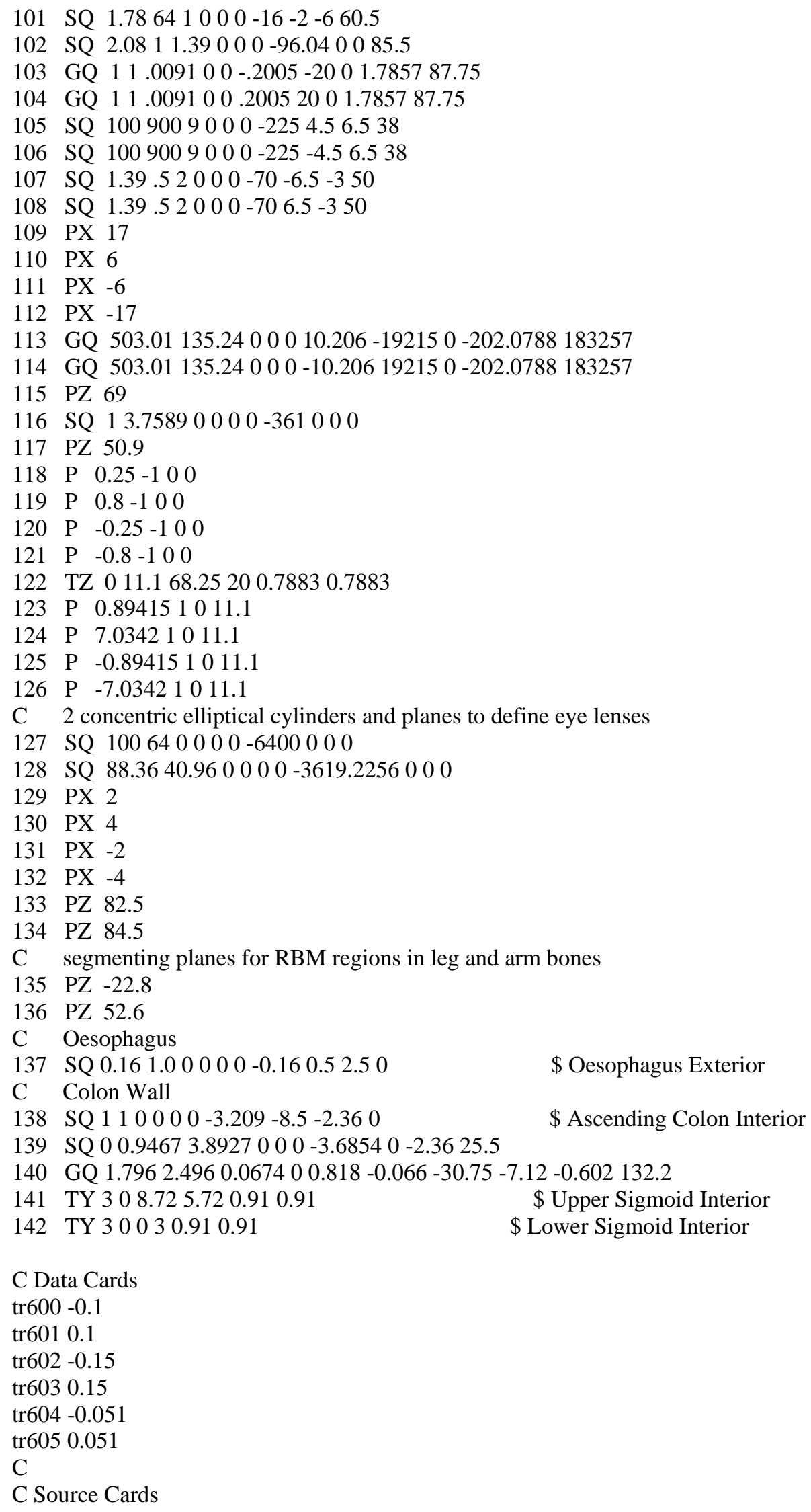


SDEF PAR=2 ERG=D1 CEL=600 POS $00-80.5$

$\mathrm{RAD}=\mathrm{D} 3 \mathrm{EXT}=\mathrm{D} 4 \mathrm{EFF}=1 \mathrm{E}-4 \mathrm{AXS} 0001$

SI1 L 1.1731 .332

SP1 0.99850 .999826

SI3 020.21

SP3 -21 1

SI4 0174.75

SP4 -21 0

$\mathrm{C}$

C Tally Cards

*F8:P $3536 \mathrm{~T}$

FC8 Gonad Gamma Dose

*F18:E 3536 T

FC18 Gonad Electron Dose

*F28:P 37

FC28 Thyroid Gamma Dose

*F38:E 37

FC38 Thyroid Electron Dose

*F48:P 91011121314151617181920383949

$5051545556575859 \mathrm{~T}$

FC48 Bone Gamma Dose

*F58:E 91011121314151617181920383949

$5051545556575859 \mathrm{~T}$

FC58 Bone Electron Dose

*F68:P $224 \mathrm{~T}$

FC68 Lung Gamma Dose

*F78:E $224 \mathrm{~T}$

FC78 Lung Electron Dose

*F88:P 29

FC88 Stomach Gamma Dose

*F98:E 29

FC98 Stomach Electron Dose

*F108:P 3031323363646566

FC108 Colon Gamma Dose

*F118:E 3031323363646566

FC118 Colon Electron Dose

*F128:P 45

FC128 Bladder Gamma Dose

*F138:E 45

FC138 Bladder Electron Dose

*F148:P 27

FC148 Liver Gamma Dose

*F158:E 27

FC158 Liver Electron Dose

*F168:P 62

FC168 Oesophagus Gamma Dose

*F178:E 62

FC178 Oesophagus Electron Dose

*F188:P 700

FC188 Skin Gamma Dose

*F198:E 700

FC198 Skin Electron Dose

$\mathrm{C}$

C Material Cards

C THIS IS THE COMPOSITION FOR AIR

M1 $7014-.7558 \quad 8016-.231418000-.0128$ 


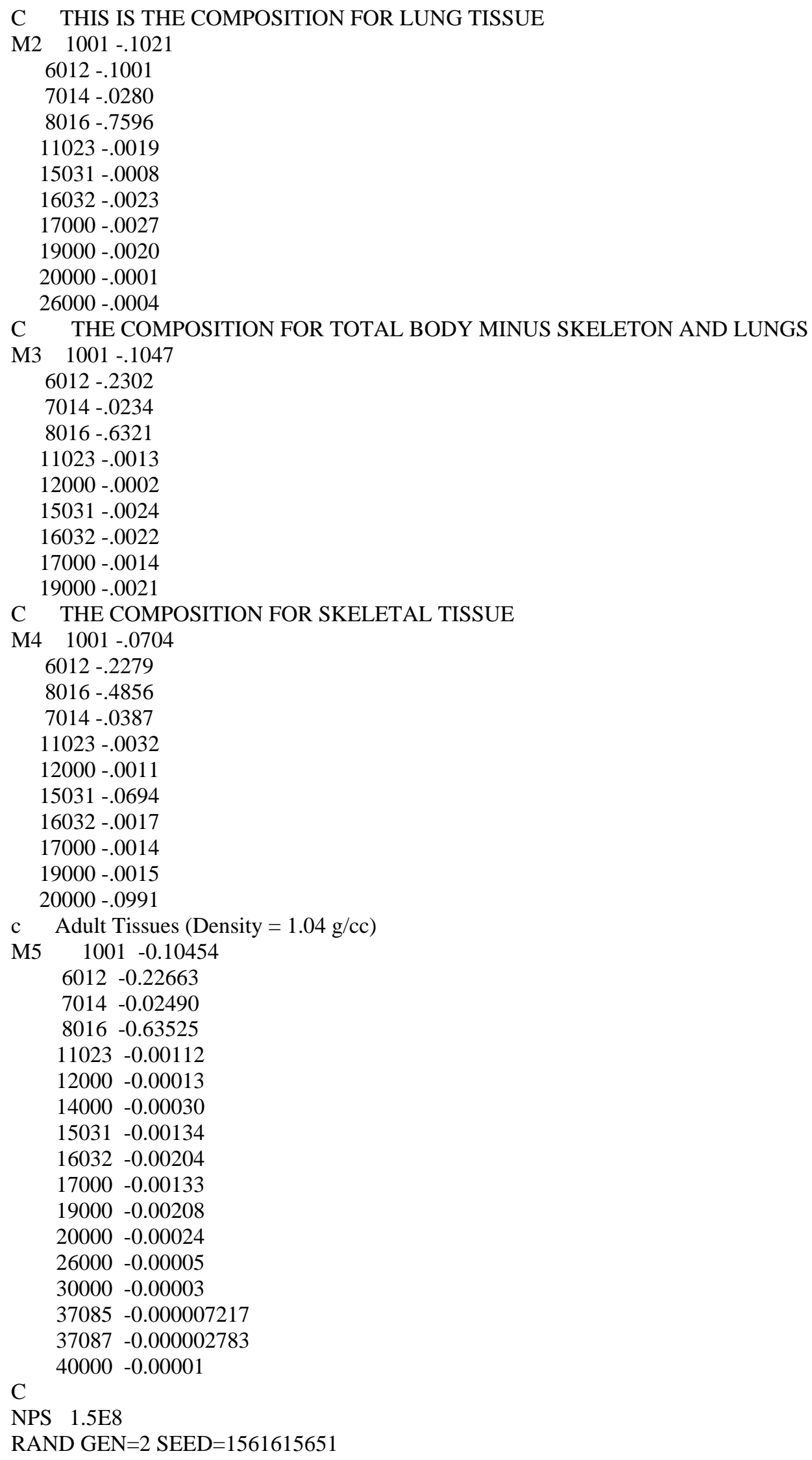


PHYS:P 4J 1

PRINT

MODE P E 


\section{APPENDIX D \\ REFENCE FEMALE INPUT FILE}

Neutron \& Induced Photon Calculations in MIRDETTE Phantom: Oes \& Colon Wall

C Am-241 Skin Source

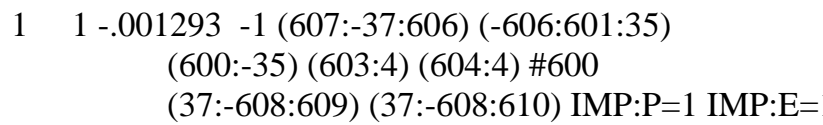

$22-0.2958((-2-43):(-24)) 5$ IMP:P=1 VOL=8.22E3 IMP:E=1 \$ left lung

$3 \quad 3-0.9869-75-6(-8: 32) 84101$ \#2 \#24 \#28 \#54 \&

\#55 \#58 \#59 \#62 \#700 IMP:P=1 VOL=4.09E4 IMP:E=1

$4 \quad 3-0.9869-78-32116112113$ \#15 \#16 \#17 \#18 \& \#19 \#20 \#56 \#57 \#700 IMP:P=1 VOL=6.33E3 IMP:E=1

$5 \quad 3-0.9869-78-1165112113 \# 9 \# 13 \# 14$ \& \#700 IMP:P=1 VOL=3.33E3 IMP:E=1 \$ torso

$6 \quad 3-0.9869-750-5568496105106112113 \# 10$ \#11 \#12 \#27 \#43 \#44 \#47 \& \#700 IMP:P=1 VOL=3.29E4 IMP:E=1 \$ torso

$7 \quad 3-0.9869-797-50(83:-86: 87:-88) 7273112113$ \#25 \#30 \#33 \#38 \#39 \#43 \#44 \#63 \#64 \& \#65 \#700 IMP:P=1 VOL=3.43E4 IMP:E=1

$8 \quad 3-0.9869-737-9795112113$ \#31 \#33 \#38 \#65 \& \#66 \#700 IMP:P=1 VOL=3.18E4 IMP:E=1 \$ torso

94 -1.4862 8 -9 5 -10 IMP:P=1 VOL=2.83E2 IMP:E=1 \$ rib

$104-1.4862$ 8 -9 11 -12 IMP:P=1 VOL=2.83E2 IMP:E=1 \$ rib

$114-1.48628$-9 13 -14 IMP:P=1 VOL=2.83E2 IMP:E=1 \$ rib

$124-1.48628-915-16$ IMP:P=1 VOL=2.83E2 IMP:E=1 \$ rib

$134-1.48628-917-18$ IMP:P=1 VOL=2.83E2 IMP:E=1 \$ rib

$14 \quad 4-1.48628-919-20$ IMP:P=1 VOL=2.83E2 IMP:E=1 \$ rib

$154-1.48628-921-22$ IMP:P=1 VOL=2.83E2 IMP:E=1 \$ rib

$164-1.48628$-9 23 -24 IMP:P=1 VOL=2.83E2 IMP:E=1 \$ rib

174 -1.4862 8 -9 25 -26 IMP:P=1 VOL=2.83E2 IMP:E=1 \$ rib

$18 \quad 4-1.48628-927-28$ IMP:P=1 VOL=2.83E2 IMP:E=1 \$ rib

$194-1.48628$-9 29 -30 IMP:P=1 VOL=2.83E2 IMP:E=1 \$ rib

$204-1.4862 \quad 8$-9 31 -32 IMP:P=1 VOL=2.83E2 IMP:E=1 \$ rib

$21 \quad 3-0.9869 \quad((35-34):(-336-35)) 102(84: 85) \# 37$

\#60 \#61 \#62 \#700 IMP:P=1 VOL=9.27E3 IMP:E=1 \$ head

$223-0.9869-3738-39103$ \#700 IMP:P=1 VOL=4.21E4 IMP:E=1 \$ left leg

$23 \quad 3-0.9869-3738-40104$ \#22 \#700 IMP:P=1 \& $\mathrm{VOL}=4.21 \mathrm{E} 4 \mathrm{IMP}: \mathrm{E}=1 \quad$ \$ right leg

$242-0.2958 \quad((-41-442):(-414)) 5$ IMP:P=1 \& $\mathrm{VOL}=8.22 \mathrm{E} 3 \mathrm{IMP}: \mathrm{E}=1 \quad$ right lung

253 -0.9869 45 -46 IMP:P=1 VOL=4.89E2 IMP:E=1 \$ uterus

$263-0.9869$-47 IMP:P=1 VOL=6.97E3 IMP:E=1 \$ brain

$273-0.986950-51-48$-49 IMP:P=1 VOL=8.84E3 IMP:E=1 \$ liver

$28 \quad 3-0.9869 \quad(-5254):(-53-5455)$ IMP:P $=1 \&$ $\mathrm{VOL}=3.01 \mathrm{E} 3 \mathrm{IMP}: \mathrm{E}=1 \quad$ \$ heart

$293-0.9869$-56 IMP:P=1 VOL=1.99E3 IMP:E=1 \$ stomach

$30 \quad 3-0.9869-5713858$-59 IMP:P=1 VOL=4.51E2 IMP:E=1 \$ Ascending Colon Wall

$313-0.9869 \quad(-6314165-61):(-6414237-65) \&$ IMP:P=1 VOL=3.49E2 IMP:E=1 \$ Sigmoid Colon Wall 


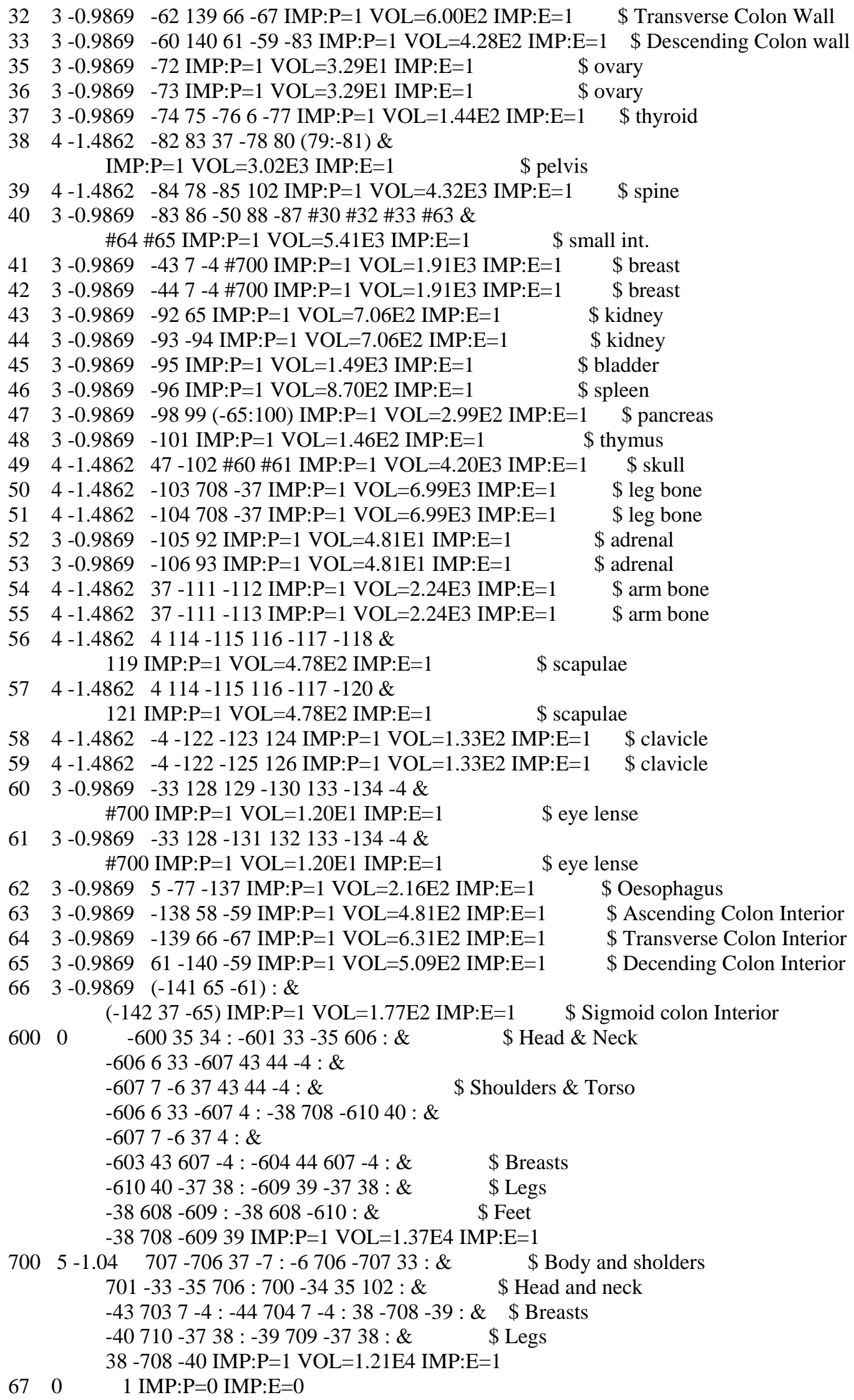


1 SO 200

2 SQ $23.0410 .2410000-508.968 .0040 .9$

$3 \quad$ SQ $23.0410 .2410000-508.962 .35040 .9$

4 PY 0.0

$5 \quad$ PZ 40.92

$6 \quad \mathrm{PZ} 66$

606 PZ 66.2

706 PZ 65.8

7 SQ $14.0000000-353.44000$

607 SQ $0.002770 .01085100000-10000$

707 SQ $0.0028910 .01181500000-1000$

8 SQ $13.238300000-241.180000$

9 SQ $13.091400000-2560000$

10 PZ 42.24

$11 \quad$ PZ 33.0

12 PZ 34.32

13 PZ 35.64

14 PZ 36.96

$\begin{array}{lll}15 & \text { PZ } & 38.28\end{array}$

$16 \quad$ PZ 39.60

$17 \quad$ PZ 43.56

18 PZ 44.88

19 PZ 46.20

$20 \quad$ PZ 47.52

21 PZ 48.84

22 PZ 50.16

23 PZ 51.48

24 PZ 52.80

25 PZ 54.12

26 PZ 55.44

27 PZ 56.76

28 PZ 58.08

29 PZ 59.40

$30 \quad$ PZ 60.72

$31 \quad$ PZ 62.04

32 PZ 63.36

33 SQ $88.3643 .5600000-3848.96000$

701 SQ $0.0244140 .01181500000-1000$

601 SQ $0.0216260 .01085100000-1000$

34 SQ $5941.332928 .973848 .960000-258804.180000 .8$

700 SQ $0.0244140 .0118150 .0156250000-10080.8$

600 SQ $0.0216260 .0108510 .0141720000-10080.8$

$\begin{array}{llll}35 & \text { PZ } & 80.8\end{array}$

$36 \quad$ PZ 94

$37 \quad$ PZ 0

38 PZ -75

708 PZ -74.8

608 PZ -75.2

39601 GQ $550000-1-93.50000$

709601 GQ $550000-1-92.5000$

609 GQ $550000-1-950000$

40600 GQ 55000193.5000

710600 GQ 55000192.5000

610 GQ 55000195000

41 SQ $23.0410 .241000-508.96-8.0040 .9$ 


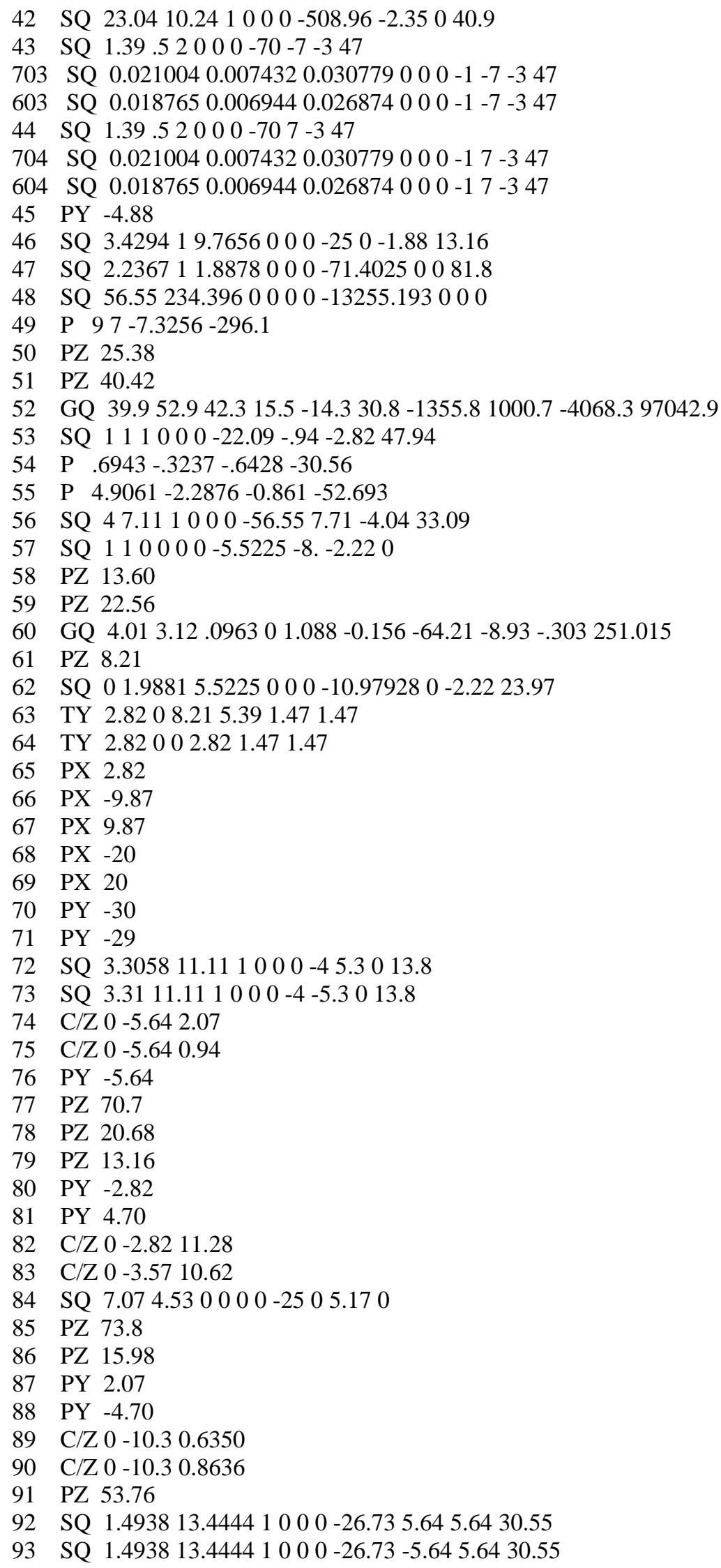




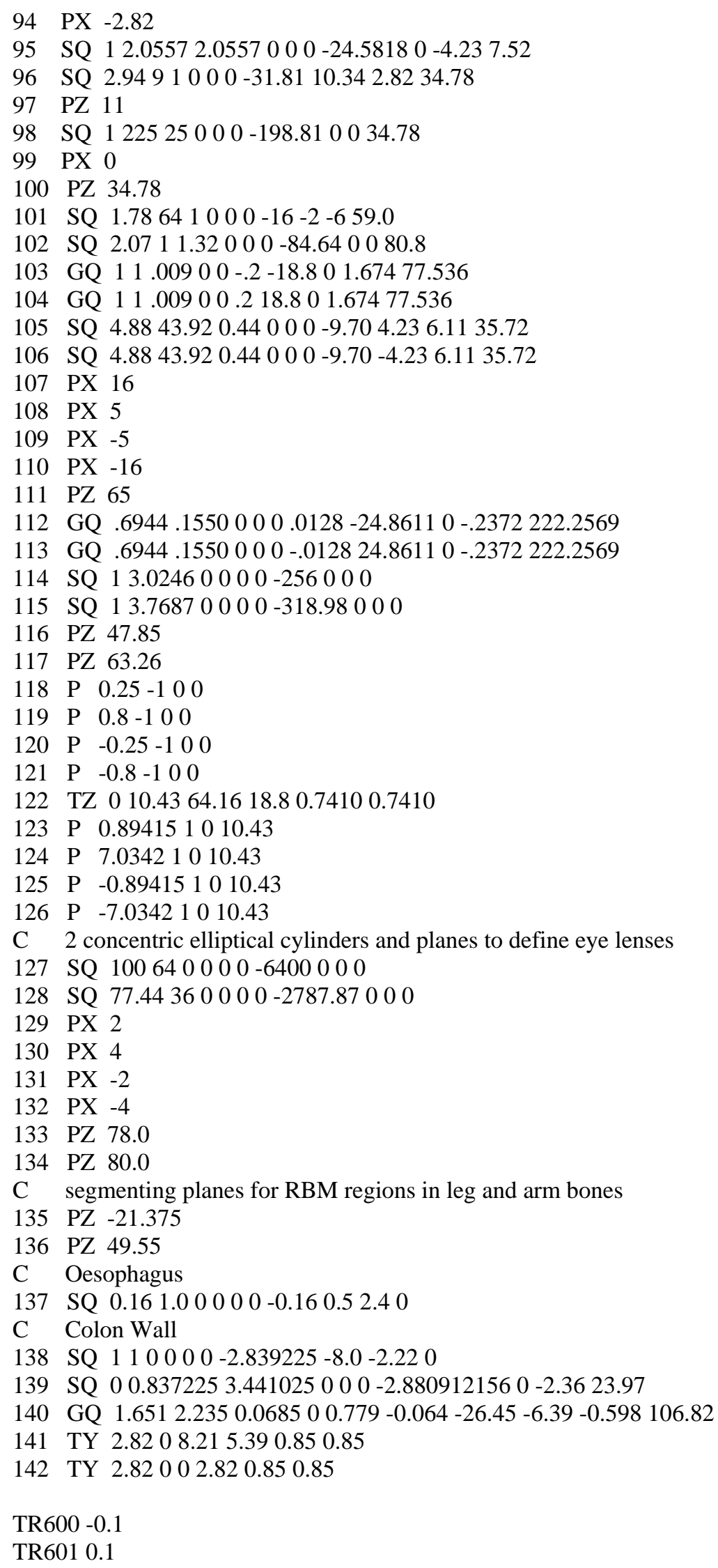

TR600 - 0.1

TR601 0.1 


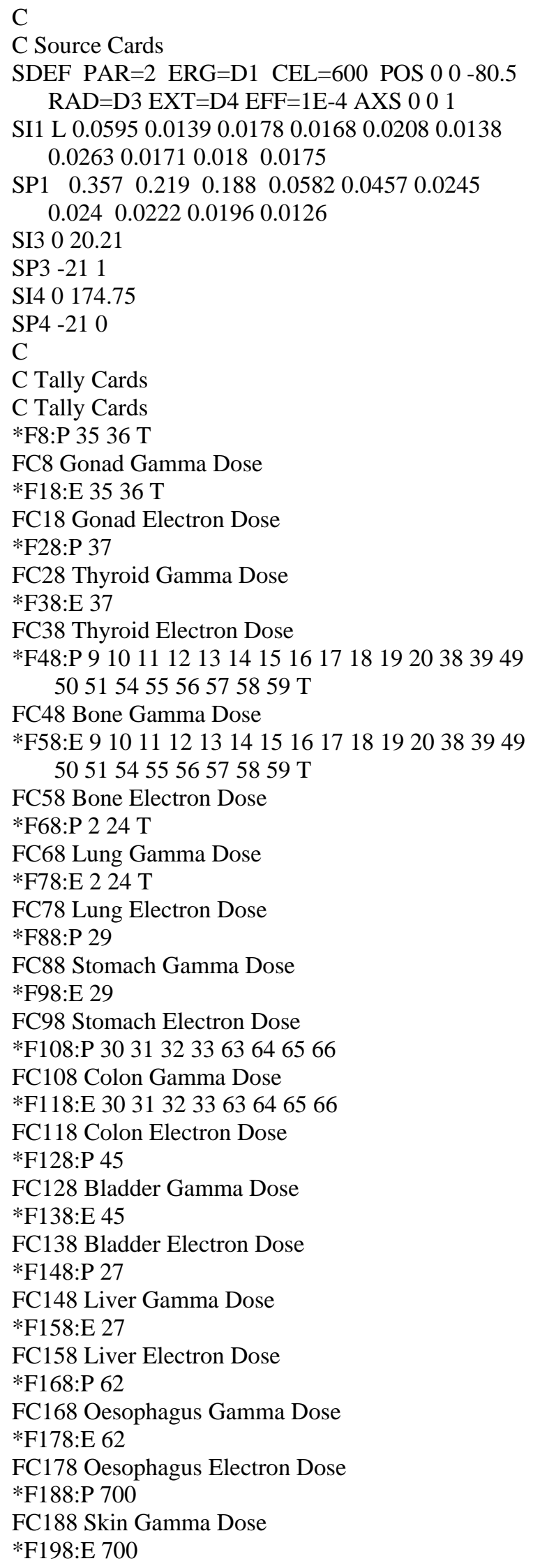




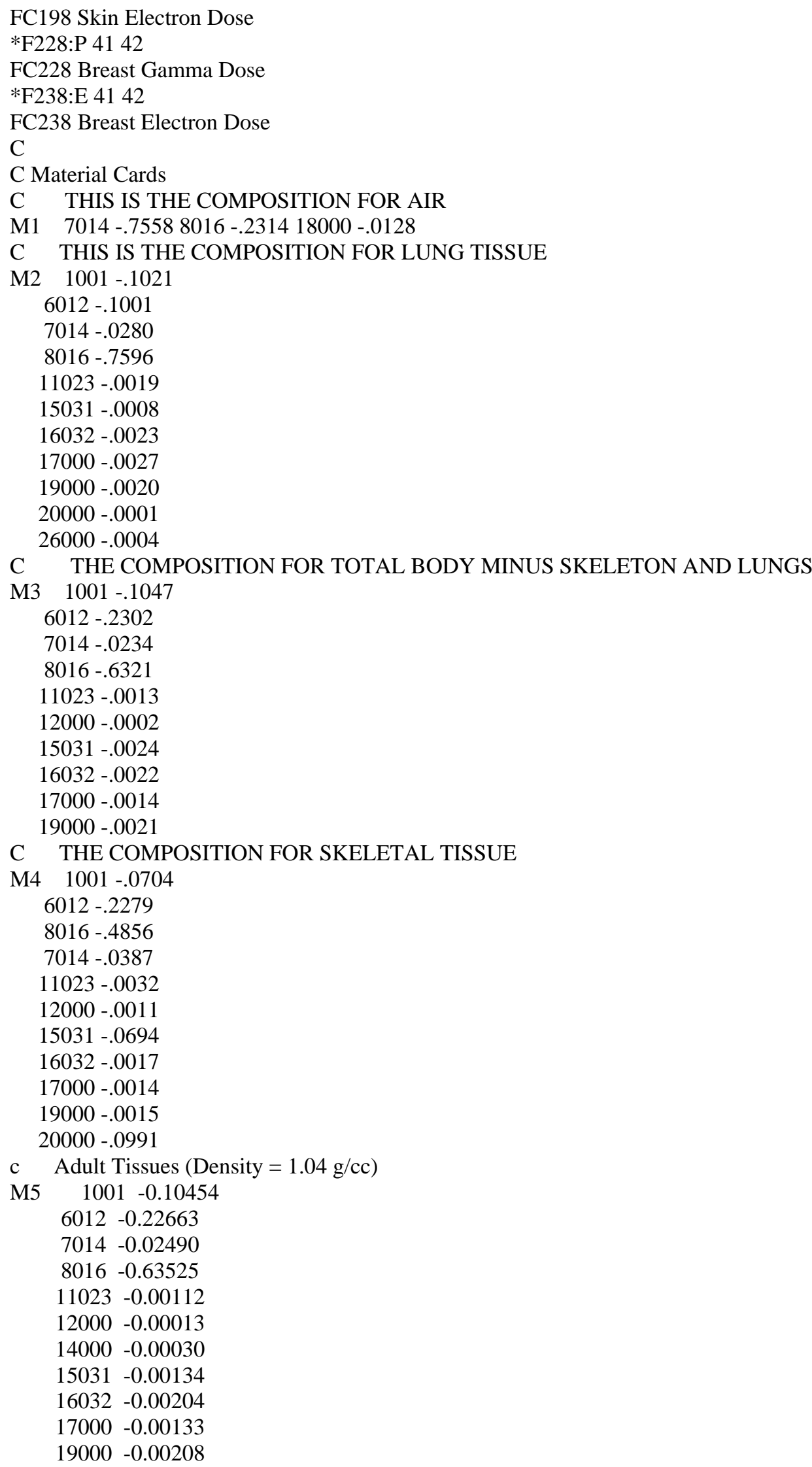




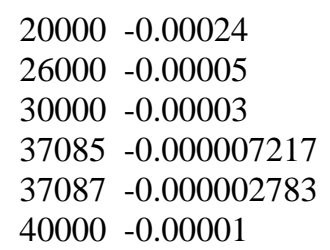




\section{APPENDIX E}

\section{ADIPOSE MALE INPUT FILE}

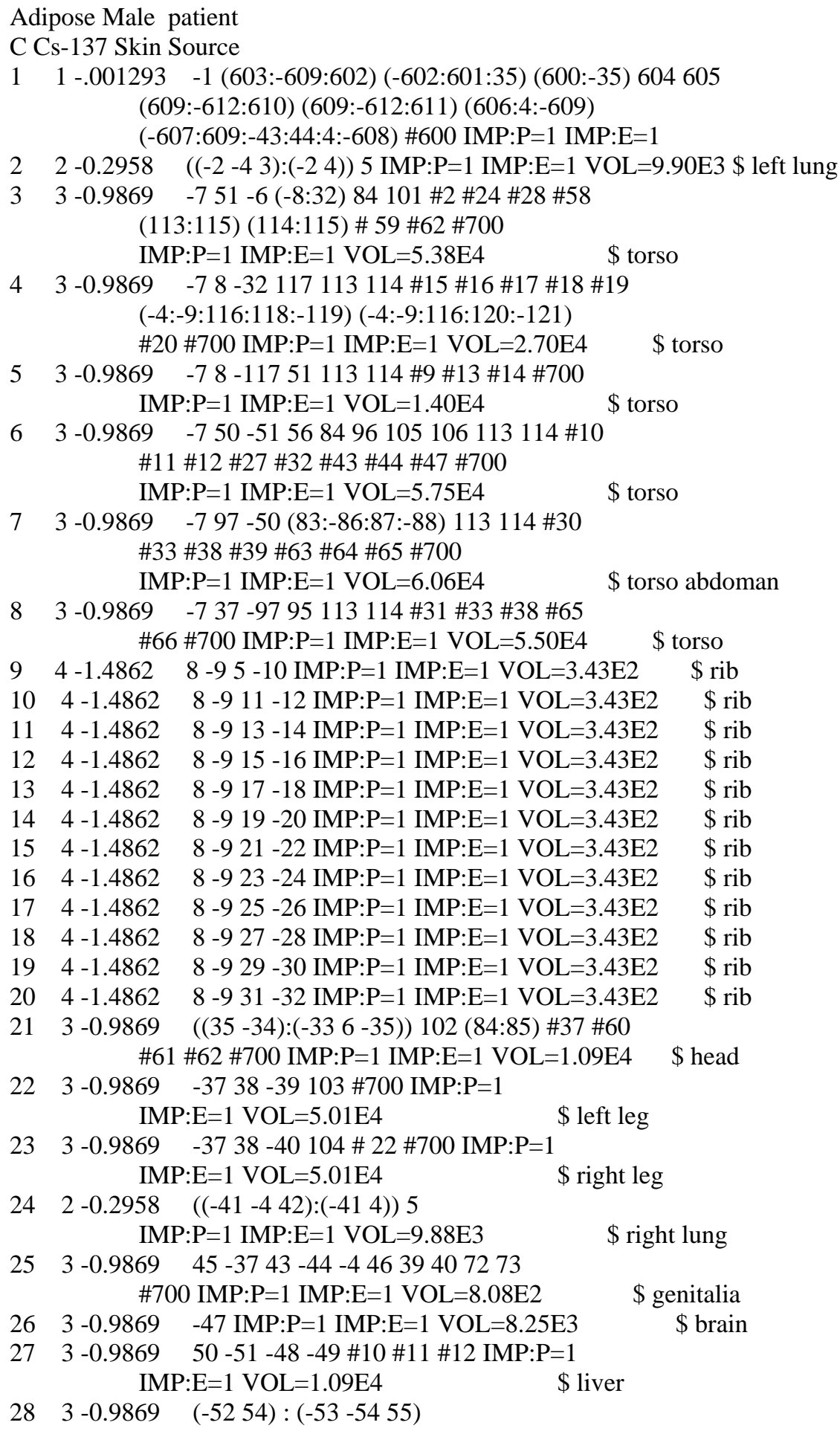




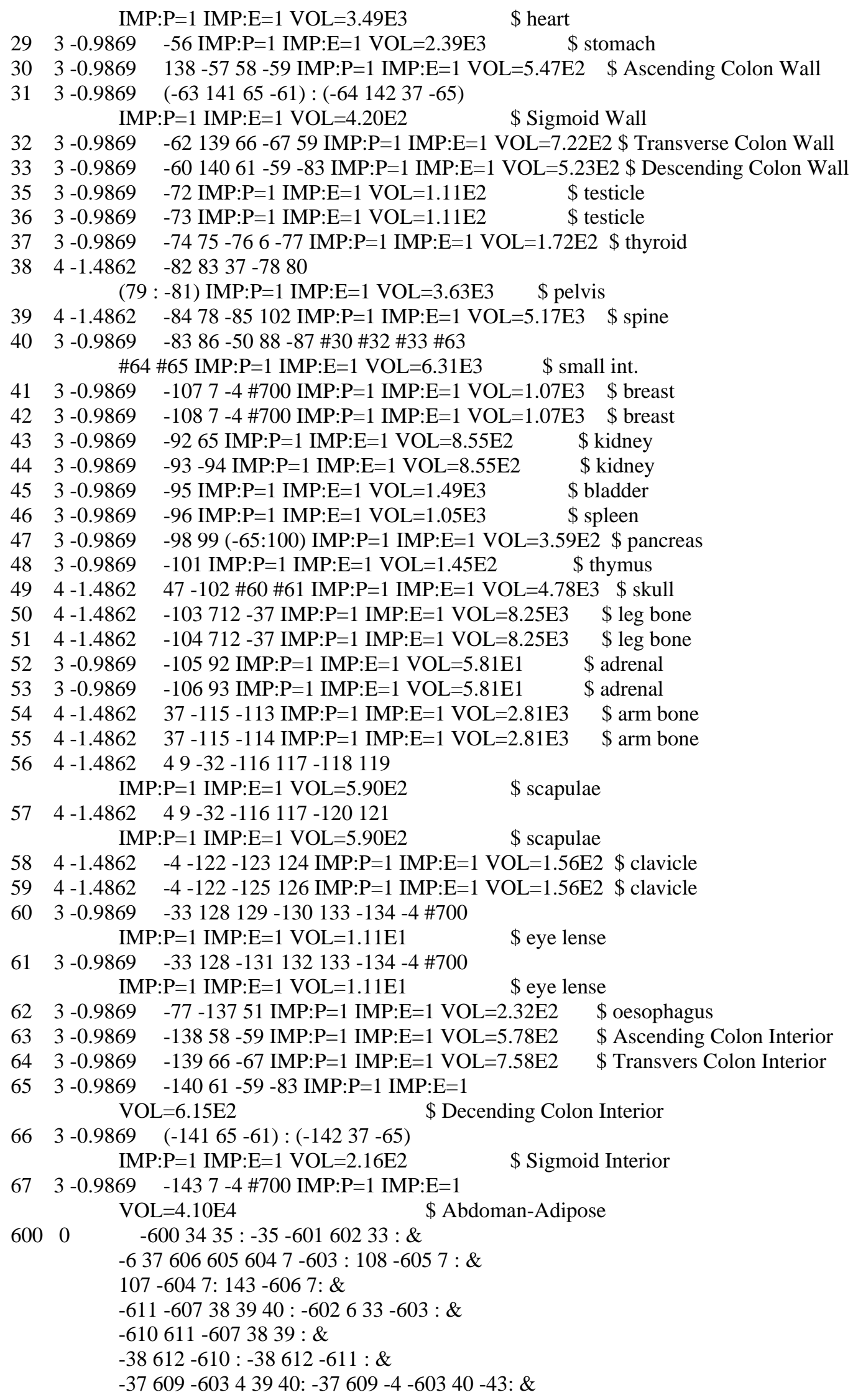




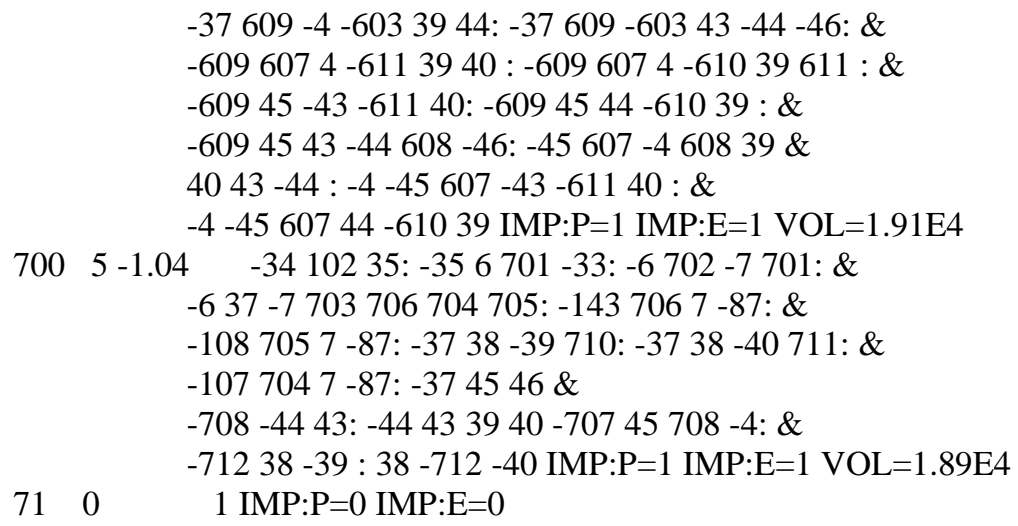


600 SQ 7874.7876 3923.76965393.4336 $0000-408228.98920085 .5$

35 PZ 85.5

$36 \quad$ PZ 94

37 PZ 0

609 PZ -0.2

$38 \quad$ PZ -80

612 PZ -80.2

712 PZ -79.8

39 GQ $550000-1-100000$

710601 GQ $550000-1-980000$

610600 GQ $550000-1-102000$

40 GQ 550001100000

711600 GQ 55000198000

611601 GQ 550001102000

41 SQ $23.0410 .24100000-576-8.5043 .5$

42 SQ $23.0410 .2410000-576-2.5043 .5$

$43 \quad \mathrm{P} \quad 10001-100$

$\begin{array}{llllll}44 & \mathrm{P} & 10 & 0 & -1 & 100\end{array}$

$45 \quad \mathrm{PZ}-4.8$

$707 \mathrm{pz}-4.6$

607 PZ -5.0

$\begin{array}{llllllllllll}46 & \mathrm{P} & 0 & 10 & 1 & -100\end{array}$

$708702 \mathrm{P} \quad 010101-100$

608602 P $0101-100$

47 SQ $2.2511 .91716000-810086.5$

48 SQ $64272.2500000-174240000$

$49 \quad \mathrm{P} \quad 97-7.3256-315$

$50 \quad$ PZ 27

$51 \quad \mathrm{PZ} 43$

52 GQ $45.259 .947 .917 .5-16.234 .8-1632.11204 .8-4898.2124295 .2$

53 SQ $11110000-25-1-351$

$\begin{array}{lllll}54 & \mathrm{P} & .6943-.3237-.6428-32.506\end{array}$

$55 \quad \mathrm{P} \quad 5.2193-2.4336-0.916-59.6345$

56 SQ $47.1110000-648-435$

57 SQ $111000000-6.25-8.5-2.360$

58 PZ 14.45

59 PZ 24

60 GQ $4.543 .53 .09601 .16-0.166-77.68-10.08-.223323 .52$

61 PZ 8.72

62 SQ $02.256 .250000-14.06250-2.3625 .5$

63 TY 308.725 .721 .571 .57

$64 \quad$ TY 300031.571 .57

65 PX 3

66 PX -10.5

67 PX 10.5

68 PX -22.1

69 PX 22.1

70 PY -30

71 PY -29

72 SQ $11.90258 .94013 .80250000-20.1152251 .3-8-2.3$

73 SQ $11.90258 .94013 .80250000-20.115225-1.3-8$ - 2.3

$74 \quad \mathrm{C} / \mathrm{Z} 0-62.2$

$75 \mathrm{C} / \mathrm{Z} 0-61$

76 PY -6

77 PZ 75

78 PZ 22 


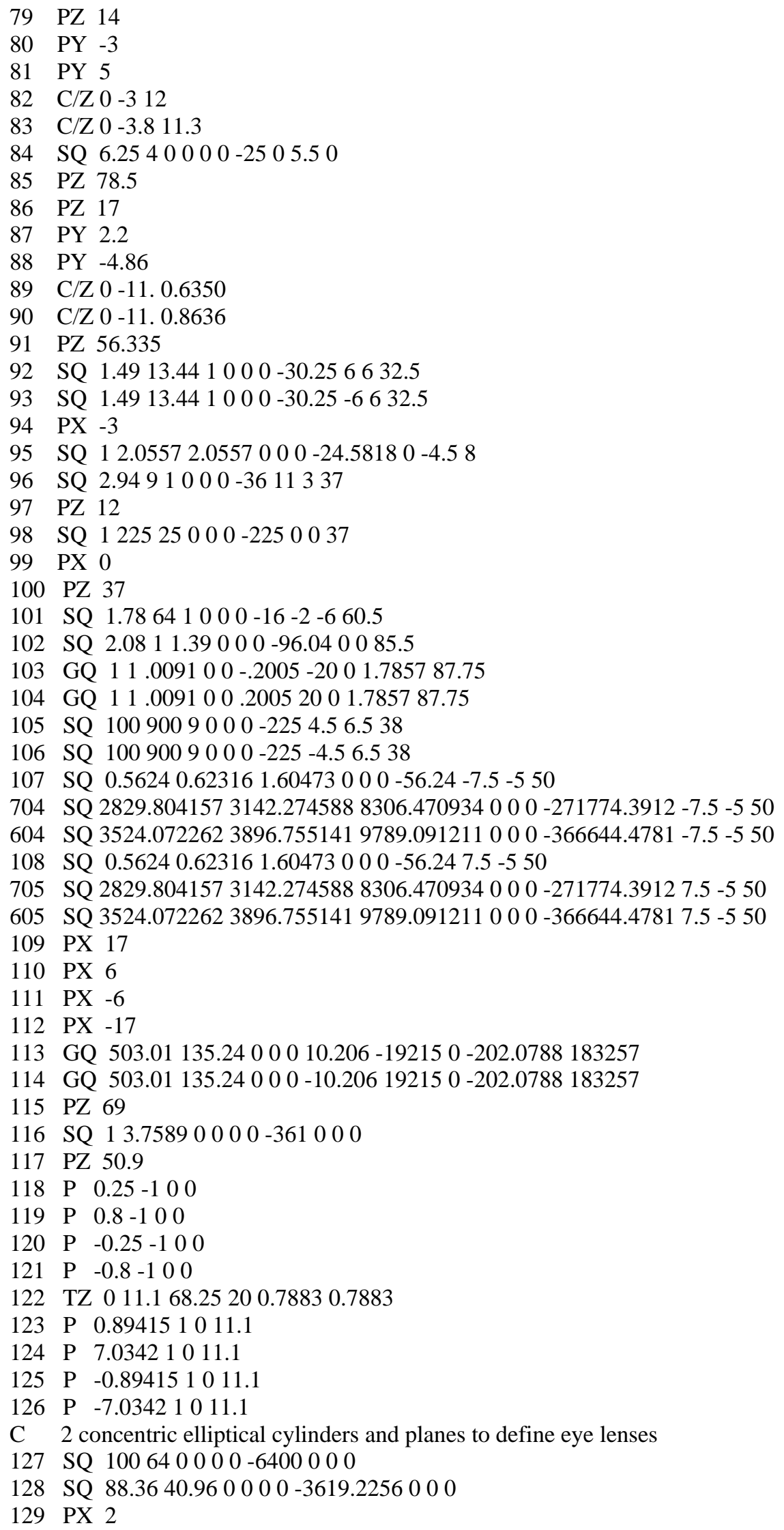




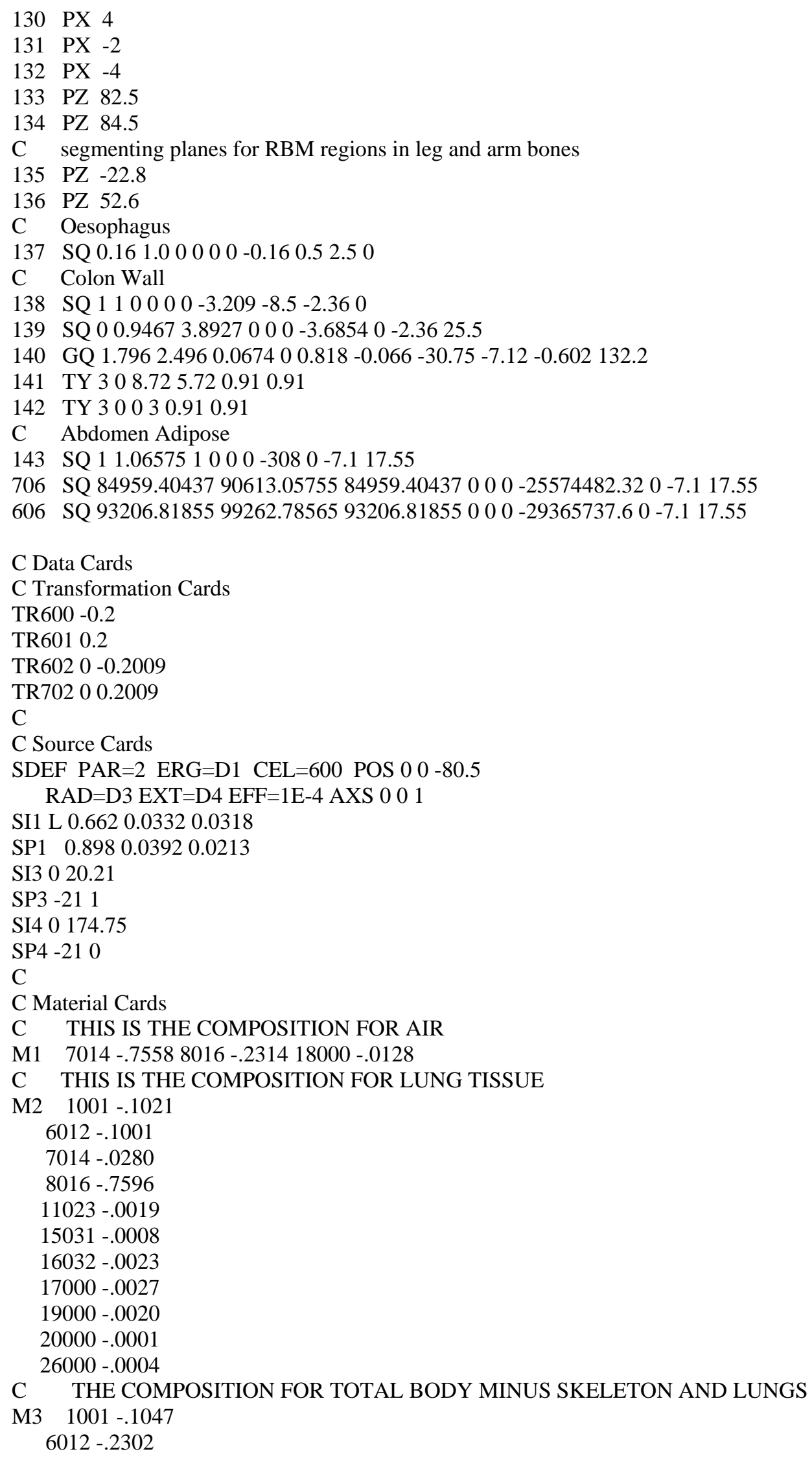




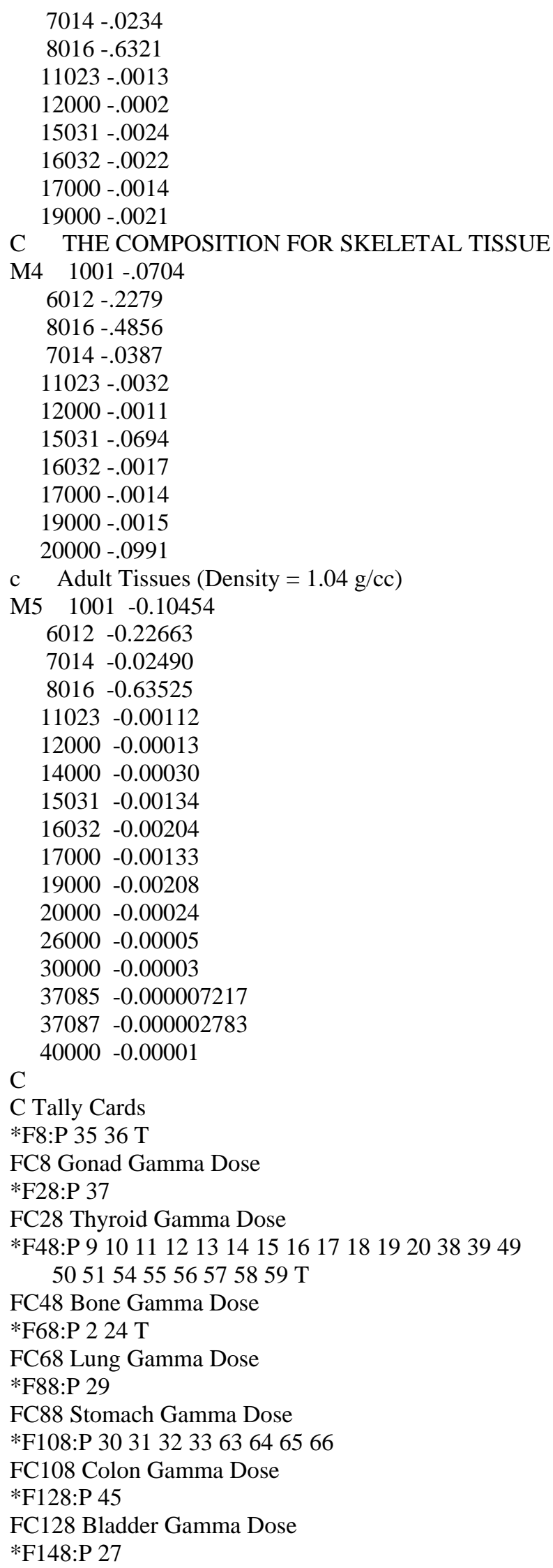




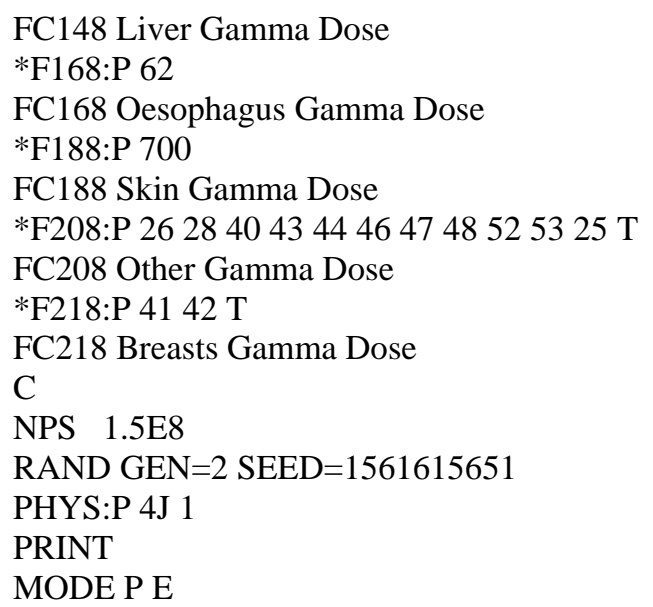




\section{APPENDIX F}

\section{ADIPOSE FEMALE INPUT FILE}

Adipose Female patient

C I-131 External Source

$1 \quad 1-.001293 \quad-1$ (607:-37:606) (-606:601:35) (600:-35)

(37:-608:609) (37:-608:610) (613:4:-37)

(603:4) (604:4) IMP:P=1 IMP:E=1

$22-0.2958 \quad((-2-43):(-24)) 5$ IMP:P=1 IMP:E $=1$ VOL=8.22E3

$3 \quad 3-0.9869-75-6(-8: 32) 84101$ \#2 \#24 \#28 \#54 \#55

\#58 \#59 \#62 \#700 IMP:P=1 IMP:E=1 VOL=4.11E4

$4 \quad 3-0.9869-78-32116112113$ \#15 \#16 \#17 \#18 \#19

\#20 \#56 \#57 IMP:P=1 IMP:E=1 VOL=7.92E3

$5 \quad 3-0.9869-78-1165112113 \# 9 \# 13 \# 14$

IMP:P=1 IMP:E=1 VOL=4.05E3 \$ torso

$6 \quad 3-0.9869-750-5568496105106112113 \# 10 \# 11$ \#12 \#27 \#43 \#44 \#47 IMP:P=1 IMP:E=1 VOL=3.45E4

$7 \quad 3-0.9869 \quad-797-50$ (83:-86:87:-88)72 73112113 \#25 \#30 \#33 \#38 \#39 \#43 \#44 \#63 \#64 \#65

IMP:P=1 IMP:E=1 VOL=3.58E4

$8 \quad 3-0.9869 \quad-737-9795112113$ \#31 \#33 \#38 \#65

\#66 IMP:P=1 IMP:E=1 VOL=3.29E4 \$ torso

$94-1.48628-95-10$ IMP:P=1 IMP:E=1 VOL=2.83E2

$104-1.48628-911-12$ IMP:P=1 IMP:E=1 VOL=2.83E2

$114-1.48628-913-14$ IMP:P=1 IMP:E=1 VOL=2.83E2

$124-1.48628-915-16$ IMP:P=1 IMP:E=1 VOL=2.83E2

$134-1.48628-917-18$ IMP:P=1 IMP:E=1 VOL=2.83E2

$14 \quad 4-1.48628-919-20$ IMP:P=1 IMP:E=1 VOL=2.83E2

$154-1.4862 \quad 8-921-22$ IMP:P=1 IMP:E $=1 \mathrm{VOL}=2.83 \mathrm{E} 2$

$16 \quad 4-1.4862 \quad 8-923-24$ IMP:P=1 IMP:E=1 VOL=2.83E2

$174-1.4862 \quad 8-925-26$ IMP:P=1 IMP:E=1 VOL=2.83E2

$184-1.4862 \quad 8-927-28$ IMP:P=1 IMP:E=1 VOL=2.83E2

$194-1.48628-929-30$ IMP:P=1 IMP:E=1 VOL=2.83E2

$204-1.4862 \quad 8-931-32$ IMP:P=1 IMP:E=1 VOL=2.83E2

$21 \quad 3-0.9869 \quad((35-34):(-336-35)) 102(84: 85) \# 37$ \#60

\#61 \#62 \#700 IMP:P=1 IMP:E=1 VOL=9.24E3

$223-0.9869-3738-39103$ \#700 IMP:P=1 IMP:E=1 $\mathrm{VOL}=4.38 \mathrm{E} 4 \quad$ \$ left leg

$23 \quad 3-0.9869-3738-40104$ \#700 IMP:P=1 IMP:E=1 $\mathrm{VOL}=4.38 \mathrm{E} 4 \quad$ \$ right leg

$24 \quad 2-0.2958 \quad((-41-442):(-414))$

5 IMP:P=1 IMP:E=1 VOL=8.22E3 \$ right lung

$253-0.986945-46$ IMP:P=1 IMP:E=1 VOL=4.89E2

$263-0.9869 \quad-47$ IMP:P=1 IMP:E=1 VOL=6.97E3

$273-0.986950-51-48$-49 IMP:P=1 IMP:E=1 VOL=8.84E3

$283-0.9869 \quad(-5254):(-53-54$ 55) IMP:P=1 IMP:E=1

$\mathrm{VOL}=3.01 \mathrm{E} 3 \quad$ \$ heart

$293-0.9869 \quad-56$ IMP:P=1 IMP:E=1 VOL=1.99E3

$30 \quad 3-0.9869-5713858-59$ IMP:P=1 IMP:E=1 VOL=4.53E2

$31 \quad 3-0.9869 \quad(-6314165-61):(-6414237-65)$

IMP:P=1 IMP:E=1 VOL=3.49E2 \$ Sigmoid Colon Wall
\$ left lung

\$ torso

\$rib

$\$$ rib

$\$$ rib

$\$$ rib

$\$$ rib

$\$$ rib

$\$$ rib

$\$$ rib

$\$$ rib

$\$$ rib

$\$$ rib

$\$$ rib

\$ head
\$ uterus

$\$$ brain

$\$$ liver

\$ stomach

\$ Ascending Colon Wall 


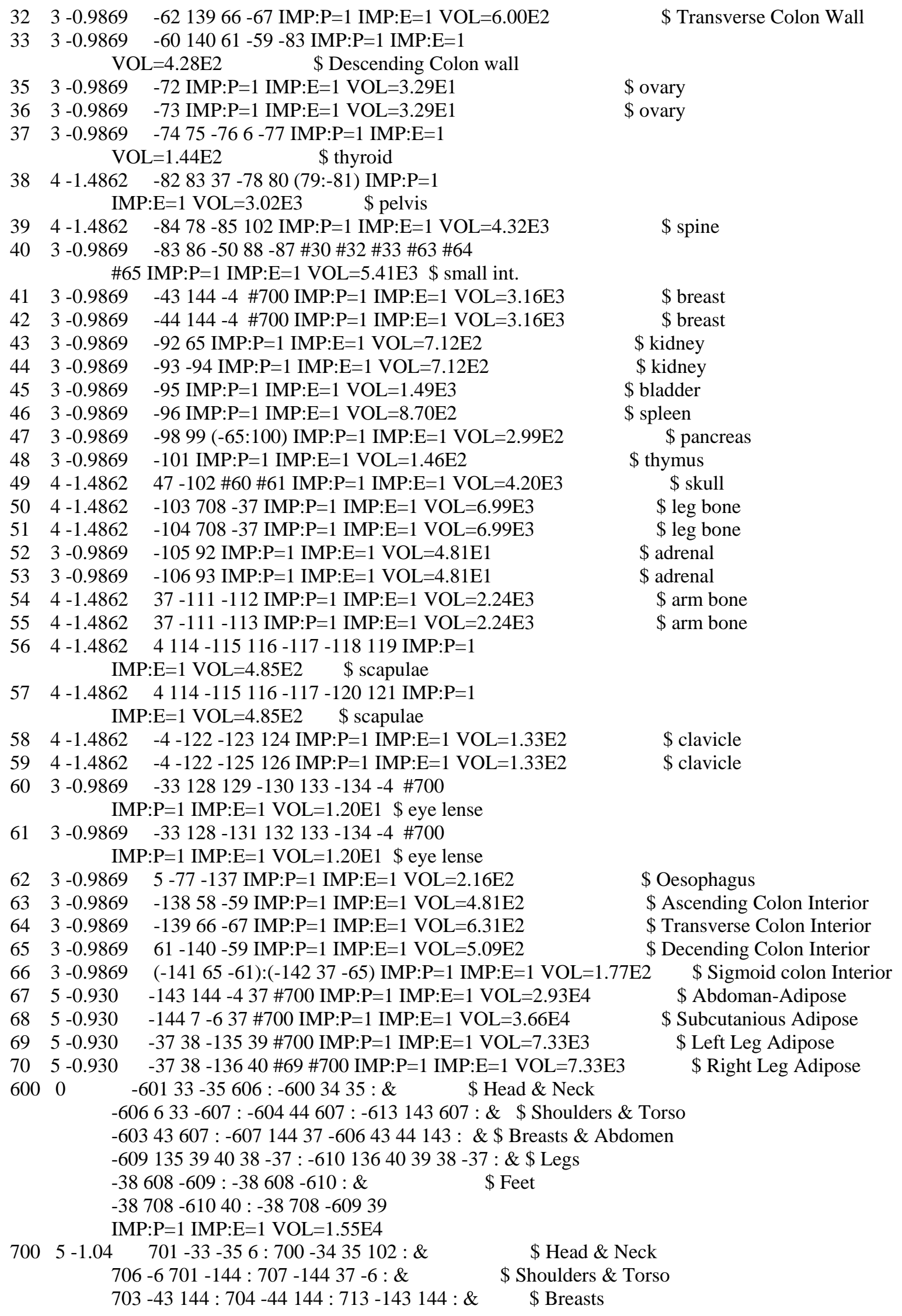




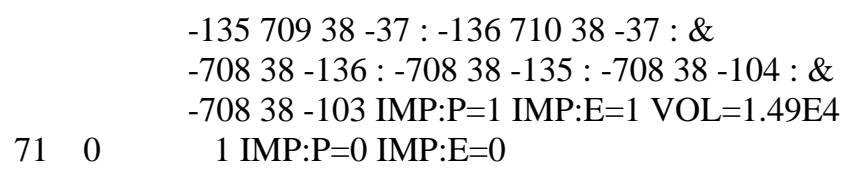




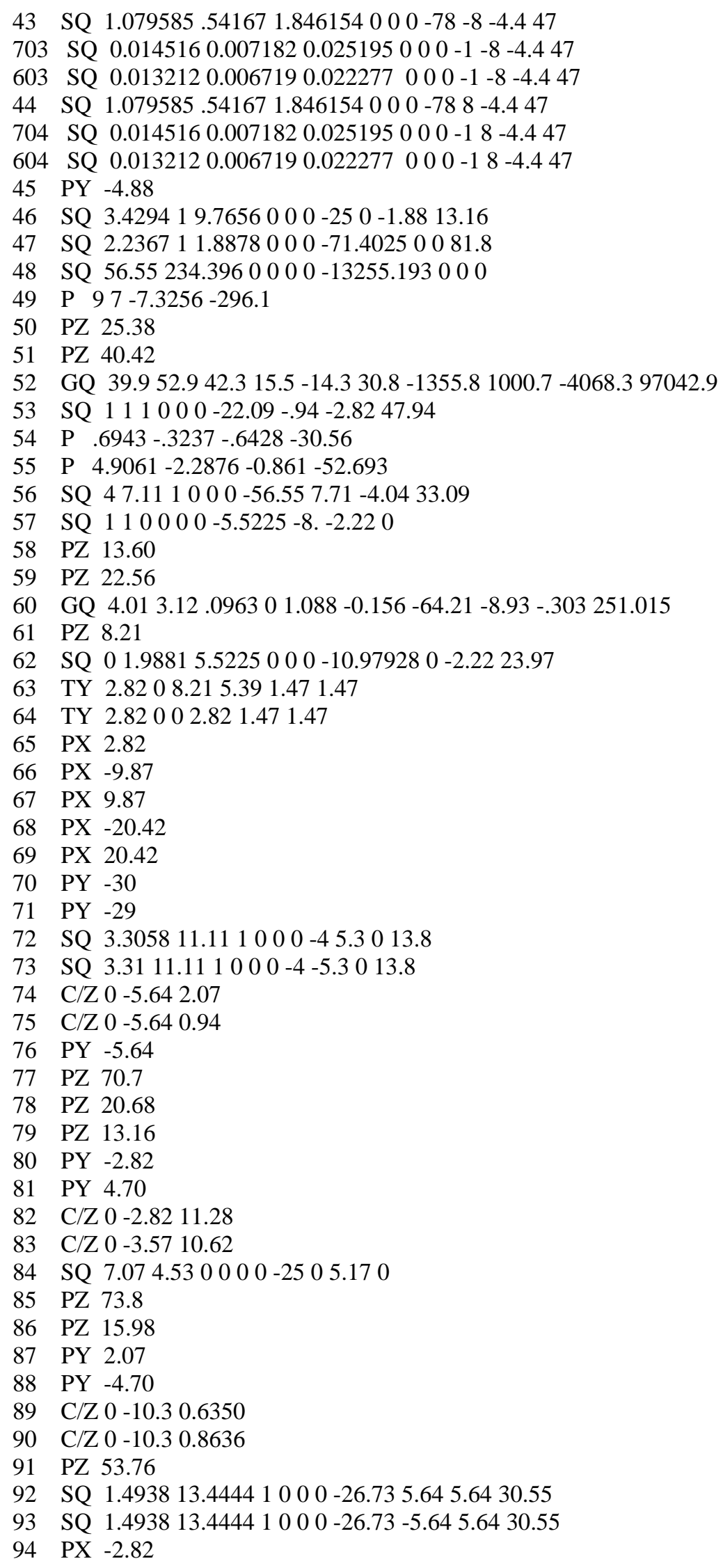




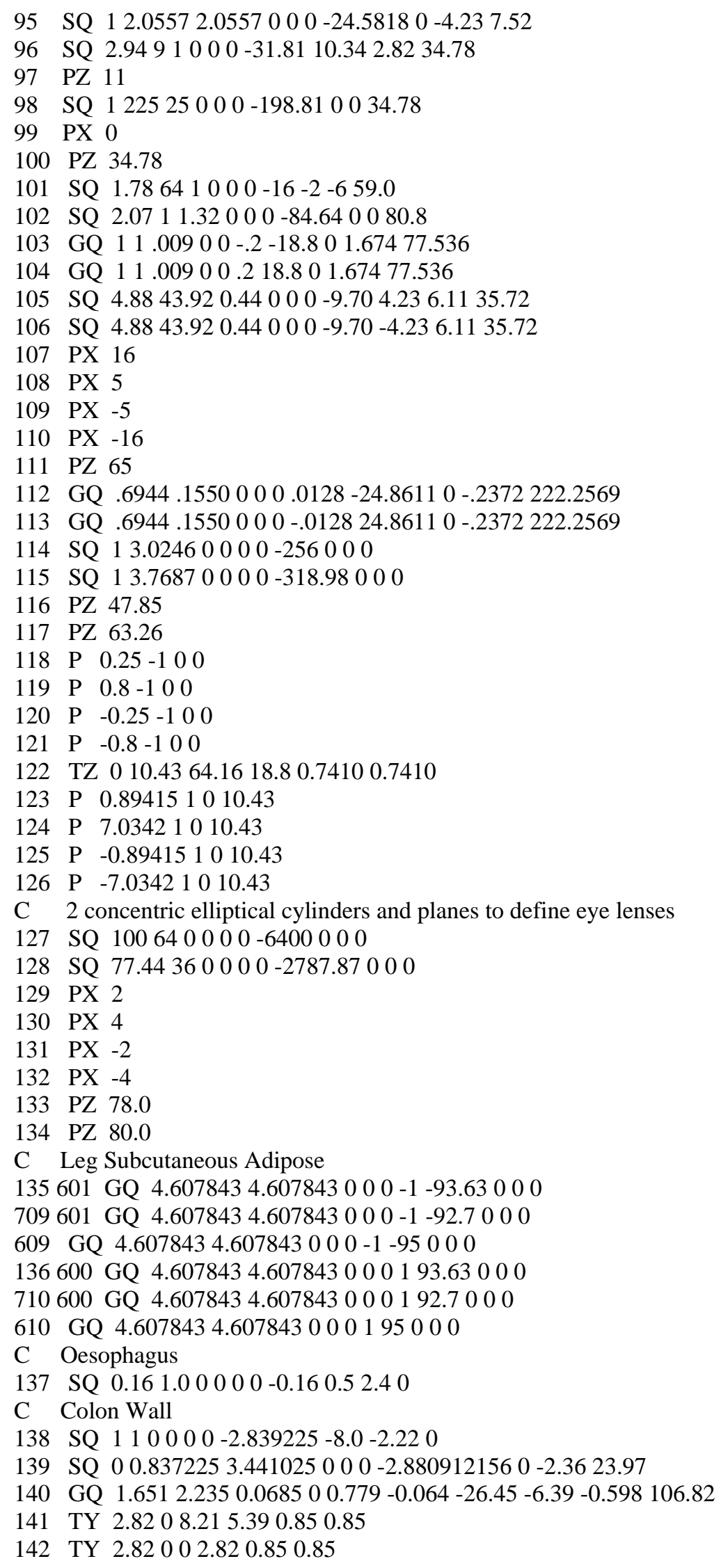




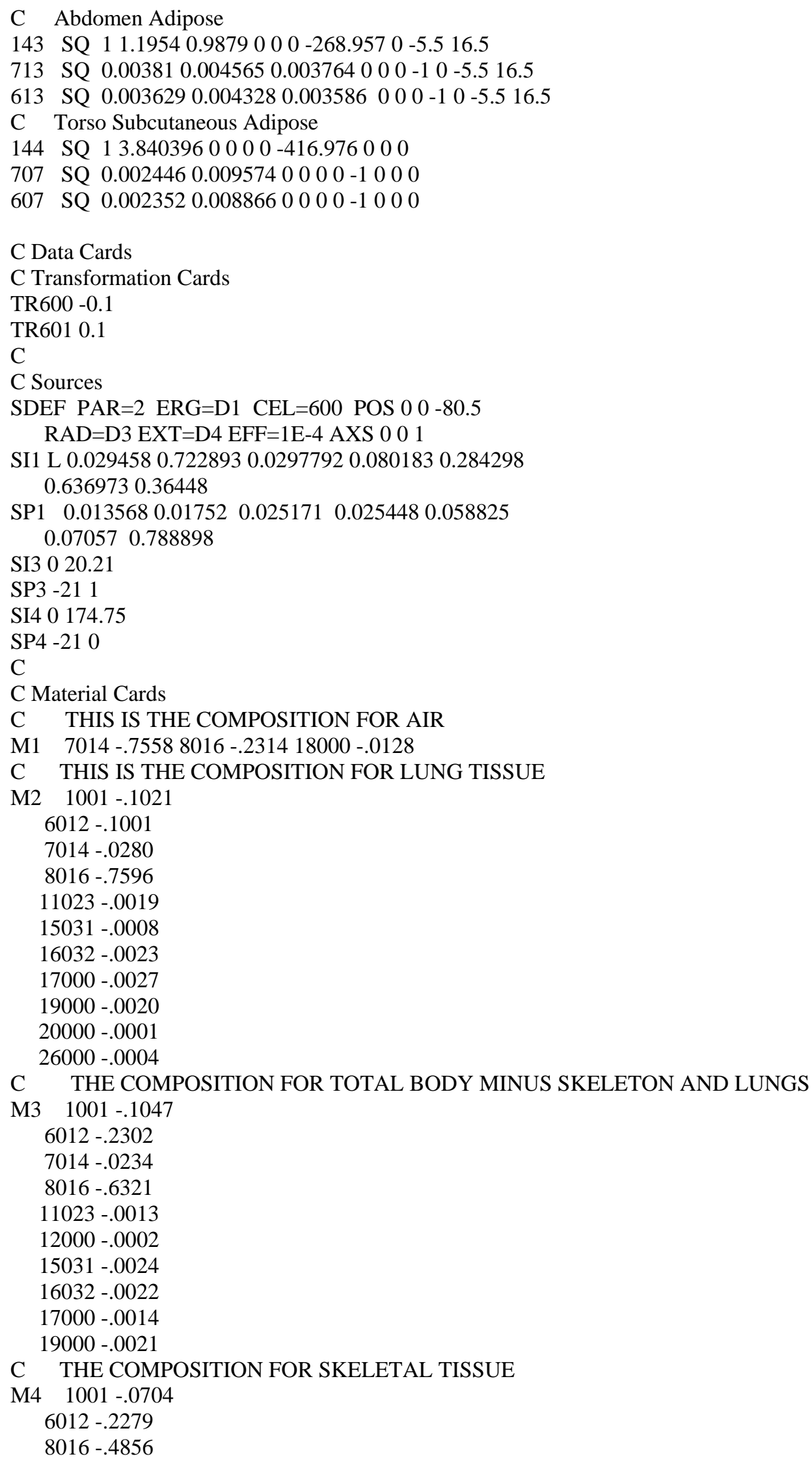




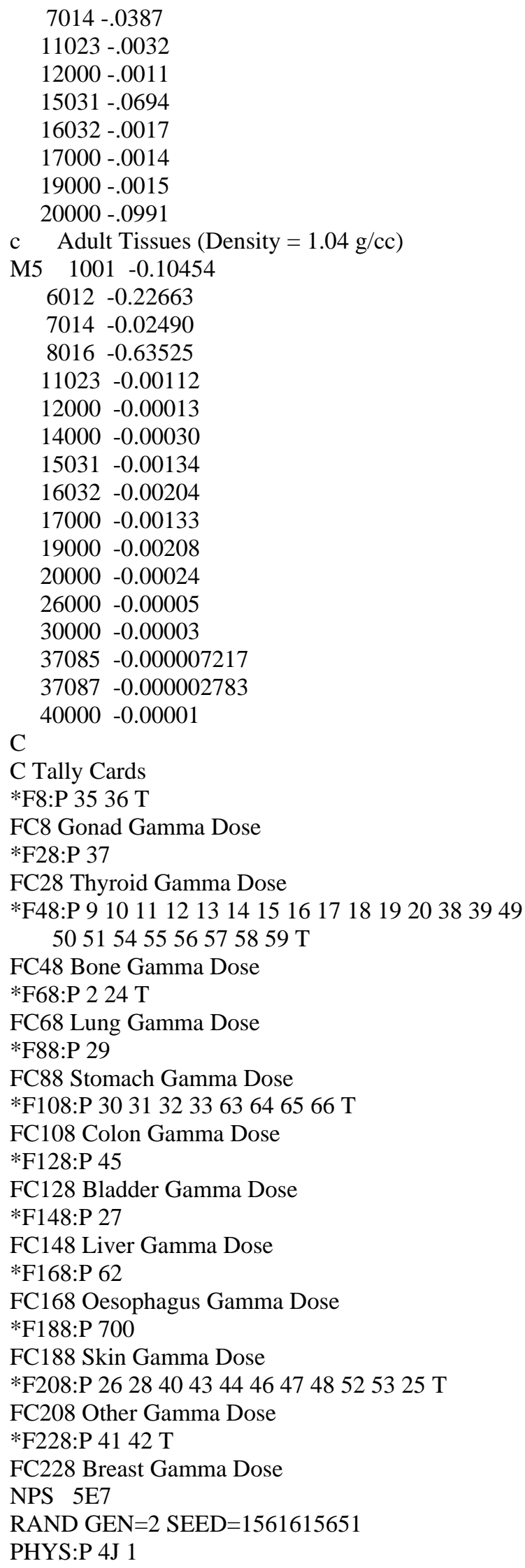


PRINT

MODE P E 


\section{APPENDIX G}

\section{POSTMENOPAUSAL ADIPOSE FEMALE INPUT FILE}

Neutron \& Induced Photon in Adipose PM MIRDETTE Phantom: Oes \& Colon Wall C Sr-90 Skin Source
$1 \quad 1-.001293 \quad-1(607:-37: 606)(-606: 601: 35) \&$
$(600:-35)(603: 4)(604: 4)(37:-608: 609) \&$
(37:-608:610) (613:4:-37) IMP:P=1 IMP:E=1

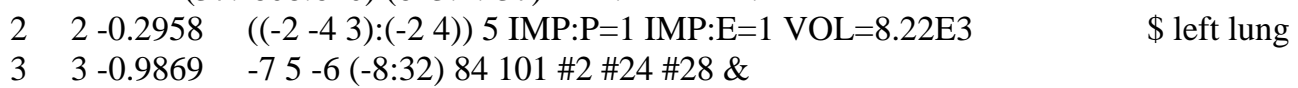
\#54 \#55 \#58 \#59 \#62 \#700 IMP:P=1 IMP:E=1 VOL=4.38E4
$4 \quad 3-0.9869-78-32116112113$ \#15 \#16 \#17 \&
\#18 \#19 \#20 \#56 \#57 \#700 IMP:P=1 IMP:E=1 VOL=2.52E4
$5 \quad 3-0.9869 \quad-78-1165112113 \# 9 \# 13 \# 14$ \#700
IMP:P=1 IMP:E=1 VOL=1.18E4 \$ torso
$6 \quad 3-0.9869 \quad-750-5568496105106112113$ \#10 \#11 \& \#12 \#27 \#43 \#44 \#47 \#700 IMP:P=1 IMP:E=1 VOL=5.21E4 \$ torso
$73-0.9869 \quad-797-50(83:-86: 87:-88) 7273112 \&$
113 \#25 \#30 \#33 \#38 \#39 \#43 \#44 \&
\#63 \#64 \#65 \#700 IMP:P=1 IMP:E=1 VOL=5.22E4
$8 \quad 3-0.9869 \quad-737-9795112113$ \#31 \#33 \#38 \& \#65 \#66 \#700 IMP:P=1 IMP:E=1 VOL=4.55E4
$94-1.48628-95-10$ IMP:P=1 IMP:E=1 VOL=2.83E2
$104-1.4862 \quad 8-911-12$ IMP:P=1 IMP:E=1 VOL=2.83E2
$114-1.48628-913-14$ IMP:P=1 IMP:E=1 VOL=2.83E2
$124-1.48628-9$ 15 -16 IMP:P=1 IMP:E=1 VOL=2.83E2
$134-1.48628-917-18$ IMP:P=1 IMP:E=1 VOL=2.83E2
$144-1.48628$-9 19-20 IMP:P=1 IMP:E=1 VOL=2.83E2
$154-1.48628$-9 21 -22 IMP:P=1 IMP:E=1 VOL=2.83E2
$164-1.48628-923-24$ IMP:P=1 IMP:E=1 VOL=2.83E2
$174-1.48628$-9 25 -26 IMP:P=1 IMP:E=1 VOL=2.83E2
$184-1.48628-927-28$ IMP:P=1 IMP:E=1 VOL=2.83E2
$194-1.48628-929-30$ IMP:P=1 IMP:E=1 VOL=2.83E2
$204-1.4862 \quad 8-931-32$ IMP:P=1 IMP:E=1 VOL=2.83E2
$213-0.9869 \quad((35-34):(-336-35)) 102(84: 85)$
\#37 \#60 \#61 \#62 \#700 IMP:P=1 IMP:E=1 VOL=9.24E3
$223-0.9869-3738-39103$ \#700 IMP:P=1 IMP:E=1 VOL=6.44E4
$233-0.9869-3738-40104$ \#22 \#700 IMP:P=1 IMP:E=1 VOL=6.44E4
$242-0.2958 \quad((-41-442):(-414)) 5$ IMP:P=1 IMP:E=1 VOL=8.22E3
$253-0.9869 \quad 45-46$ IMP:P=1 IMP:E=1 VOL=4.89E2
$263-0.9869-47$ IMP:P=1 IMP:E=1 VOL=6.97E3
$273-0.986950-51-48-49$ IMP:P=1 IMP:E=1 VOL=8.84E3
$283-0.9869 \quad(-52$ 54):(-53 -54 55) IMP:P=1 IMP:E=1 VOL=3.01E3
$293-0.9869 \quad-56$ IMP:P=1 IMP:E=1 VOL=1.99E3
$303-0.9869-5713858-59$ IMP:P=1 IMP:E=1 VOL=4.53E2
$31 \quad 3-0.9869 \quad(-6314165-61):(-6414237-65)$
IMP:P=1 IMP:E=1 VOL=3.49E2 \$ Sigmoid Colon Wall
$323-0.9869-6213966-67$ IMP:P=1 IMP:E=1 VOL=6.00E2
$33 \quad 3-0.9869-6014061-59-83$ IMP:P=1 IMP:E=1 VOL=4.28E2
$353-0.9869 \quad-72$ IMP:P=1 IMP:E=1 VOL=3.29E1

\$ torso
\$ rib
$\$$ rib
\$ rib
\$ rib
\$ rib
\$ rib
\$ rib
\$ rib
\$ rib
\$ rib
\$ rib
\$ rib
\$ head
$\quad$ left leg
$\quad$ right leg
\$ right lung
\$ uterus
\$ brain
\$ liver
\$ heart
\$ stomach
\$ Ascending Colon Wall
\$ ovary




\begin{tabular}{|c|c|c|c|}
\hline 36 & $3-0.9869$ & -73 IMP:P=1 IMP:E=1 VOL=3.29E1 & $\$$ ovary \\
\hline 37 & $3-0.9869$ & -74 $75-766-77$ IMP:P=1 IMP:E=1 VOL=1.44E2 & \$ thyroid \\
\hline 38 & $4-1.4862$ & -82 $8337-7880$ (79:-81) IMP:P=1 IMP:E=1 VOL=3.02E3 & $\$$ pelvis \\
\hline 39 & $4-1.4862$ & -84 78 -85 102 IMP:P=1 IMP:E=1 VOL=4.32E3 & $\$$ spine \\
\hline 40 & $3-0.9869$ & $-8386-5088-87$ \#30 \#32 \#33 \#63 \#64 \#65 & \\
\hline \multicolumn{4}{|c|}{ IMP:P=1 IMP:E=1 VOL=5.41E3 \$ small int. } \\
\hline 41 & $3-0.9869$ & -437 -4 \#700 IMP:P=1 IMP:E=1 VOL=2.85E3 & $\$$ breast \\
\hline 42 & $3-0.9869$ & -447 -4 \#700 IMP:P=1 IMP:E=1 VOL=2.85E3 & $\$$ breast \\
\hline 43 & $3-0.9869$ & -92 65 IMP:P=1 IMP:E=1 VOL=7.12E2 & \$ kidney \\
\hline 44 & $3-0.9869$ & -93 -94 IMP:P=1 IMP:E=1 VOL=7.12E2 & \$ kidney \\
\hline 45 & $3-0.9869$ & -95 IMP:P=1 IMP:E=1 VOL=1.49E3 & $\$$ bladder \\
\hline 46 & $3-0.9869$ & -96 IMP:P=1 IMP:E=1 VOL=8.70E2 & \$ spleen \\
\hline 47 & $3-0.9869$ & -9899 (-65:100) IMP:P=1 IMP:E=1 VOL=2.99E2 & $\$$ pancreas \\
\hline 48 & $3-0.9869$ & -101 IMP:P=1 IMP:E=1 VOL=1.46E2 & $\$$ thymus \\
\hline 49 & $4-1.4862$ & $47-102$ \#60 \#61 IMP:P=1 IMP:E=1 VOL=4.20E3 & \$ skull \\
\hline 50 & $4-1.4862$ & -103 708 -37 IMP:P=1 IMP:E=1 VOL=6.99E3 & $\$$ leg bone \\
\hline 51 & $4-1.4862$ & -104 708 -37 IMP:P=1 IMP:E=1 VOL=6.99E3 & $\$$ leg bone \\
\hline 52 & $3-0.9869$ & -105 92 IMP:P=1 IMP:E=1 VOL=4.81E1 & $\$$ adrenal \\
\hline 53 & $3-0.9869$ & -106 93 IMP:P=1 IMP:E=1 VOL=4.81E1 & \$ adrenal \\
\hline 54 & $4-1.4862$ & $37-111-112$ IMP:P=1 IMP:E=1 VOL=2.24E3 & $\$$ arm bone \\
\hline 55 & $4-1.4862$ & $37-111$-113 IMP:P=1 IMP:E=1 VOL=2.24E3 & $\$$ arm bone \\
\hline 56 & $4-1.4862$ & $4114-115116-117-118119$ IMP:P=1 IMP:E=1 & \\
\hline \multicolumn{4}{|c|}{$\mathrm{VOL}=4.78 \mathrm{E} 2 \quad \$$ scapulae } \\
\hline \multicolumn{4}{|c|}{ VOL $=4.78 \mathrm{E} 2 \quad \$$ scapulae } \\
\hline 58 & $4-1.4862$ & $-4-122-123$ 124 IMP:P=1 IMP:E=1 VOL=1.32E2 & $\$$ clavicle \\
\hline 59 & $4-1.4862$ & $-4-122-125$ 126 IMP:P=1 IMP:E=1 VOL=1.32E2 & $\$$ clavicle \\
\hline 60 & $3-0.9869$ & $-33128129-130133-134-4$ \#700 IMP:P=1 & \\
\hline \multicolumn{4}{|c|}{ IMP:E=1 VOL=1.20E1 $\$$ eye lense } \\
\hline 61 & $3-0.9869$ & $-33128-131132133-134-4$ \#700 IMP:P=1 & \\
\hline \multicolumn{4}{|c|}{ IMP:E=1 VOL=1.20E1 \$ eye lense } \\
\hline 62 & $3-0.9869$ & 5 -77 -137 IMP:P=1 IMP:E=1 VOL=2.16E2 & \$ Oesophagus \\
\hline 63 & $3-0.9869$ & -13858 -59 IMP:P=1 IMP:E=1 VOL=4.81E2 & \$ Ascending Colon Interior \\
\hline 64 & $3-0.9869$ & -139 66 -67 IMP:P=1 IMP:E=1 VOL=6.31E2 & \$ Transverse Colon Interior \\
\hline 65 & $3-0.9869$ & $61-140$-59 IMP:P=1 IMP:E=1 VOL=5.09E2 & \$ Decending Colon Interior \\
\hline 66 & $3-0.9869$ & $(-14165-61):(-14237$-65) IMP:P=1 IMP:E=1 & \\
\hline \multicolumn{4}{|c|}{$\mathrm{VOL}=1.77 \mathrm{E} 2 \quad \$$ Sigmoid colon Interior } \\
\hline 67 & $3-0.9869$ & -143 7 -4 \#700 IMP:P=1 IMP:E=1 VOL=3.45E4 & \$ Abdoman-Adipose \\
\hline \multicolumn{4}{|c|}{$-606633-6074344-4: \&$} \\
\hline \multirow{2}{*}{\multicolumn{4}{|c|}{$\begin{array}{l}-6077-6374344-4143: \& \\
-606633-6074 \cdot \&\end{array}$}} \\
\hline & & & \\
\hline \multicolumn{4}{|c|}{$-6077-63744443$ : } \\
\hline \multicolumn{4}{|c|}{$607-4:-60444607-4:$} \\
\hline \multicolumn{4}{|c|}{$-61040-3738:-60939-3738: \& \quad \$$ Legs } \\
\hline \multicolumn{4}{|c|}{$-38608-609:-38608-610: \&$} \\
\hline \multicolumn{4}{|c|}{$-38708-61040:-38708-60939: \&$} \\
\hline \multicolumn{4}{|c|}{143 -613 7 IMP:P=1 IMP:E=1 VOL=1.70E4 } \\
\hline 700 & $5-1.04$ & $-7707-70637:-6706-707701: \&$ & \\
\hline \multicolumn{4}{|c|}{$701-33-35706: 700-3435102: \& \quad \$$ Head and Neck } \\
\hline \multicolumn{4}{|c|}{$-437037:-447047: \& \quad$ \$ Breasts } \\
\hline \multicolumn{4}{|c|}{$-1437137:-70838-40:-70838-39:$ \& $\$$ Abdemon } \\
\hline \multirow{2}{*}{\multicolumn{4}{|c|}{$\begin{array}{l}-40710-3738:-39709-3738: \& \quad \text { \$ Legs } \\
-70838-104:-70838-103\end{array}$}} \\
\hline & & & \\
\hline \multicolumn{4}{|c|}{ IMP:P=1 IMP:E=1 VOL=1.59E4 } \\
\hline 68 & 1 & & \\
\hline
\end{tabular}


$1 \quad$ RPP -21.602 21.602 -23.101 11.601 -75.201 89.201

2 SQ $23.0410 .2410000-508.968 .0040 .9$

3 SQ $23.0410 .2410000-508.962 .35040 .9$

4 PY 0.0

$5 \quad$ PZ 40.92

$6 \quad$ PZ 66

706 PZ 65.8

606 PZ 66.2

7 SQ $13.52385000000-457.960000$

707 SQ $0.0022250 .00797200000-1000$

607 SQ $0.0021430 .00743200000-1000$

8 SQ $13.238300000-241.180000$

9 SQ $13.091400000-2560000$

10 PZ 42.24

$11 \quad$ PZ 33.0

12 PZ 34.32

13 PZ 35.64

14 PZ 36.96

$\begin{array}{lll}15 & \text { PZ } & 38.28\end{array}$

$16 \quad$ PZ 39.60

$17 \quad$ PZ 43.56

$18 \quad$ PZ 44.88

19 PZ 46.20

20 PZ 47.52

21 PZ 48.84

22 PZ 50.16

23 PZ 51.48

24 PZ 52.80

25 PZ 54.12

26 PZ 55.44

27 PZ 56.76

28 PZ 58.08

29 PZ 59.40

$30 \quad$ PZ 60.72

$31 \quad$ PZ 62.04

32 PZ 63.36

33 SQ $88.3643 .5600000-3848.96000$

701 SQ $0.0244140 .01181500000-1000$

601 SQ $0.0216260 .0108510000-1000$

34 SQ $5941.332928 .973848 .960000-258804.180000 .8$

700 SQ $0.0244140 .0118150 .0156250000-10080.8$

600 SQ $0.0216260 .0108510 .0141720000-10080.8$

$\begin{array}{lll}35 & \text { PZ } & 80.8\end{array}$

$36 \quad$ PZ 94

$37 \quad$ PZ 0

38 PZ -75

708 PZ -74.8

608 PZ -75.2

39601 GQ $550000-1-106.5000$

709601 GQ $55000-1-105.5000$

609 GQ $55000-1-108000$

40600 GQ 550001106.5000

710600 GQ 550001105.5000

610 GQ 550001108000

41 SQ $23.0410 .2410000-508.96-8.0040 .9$ 


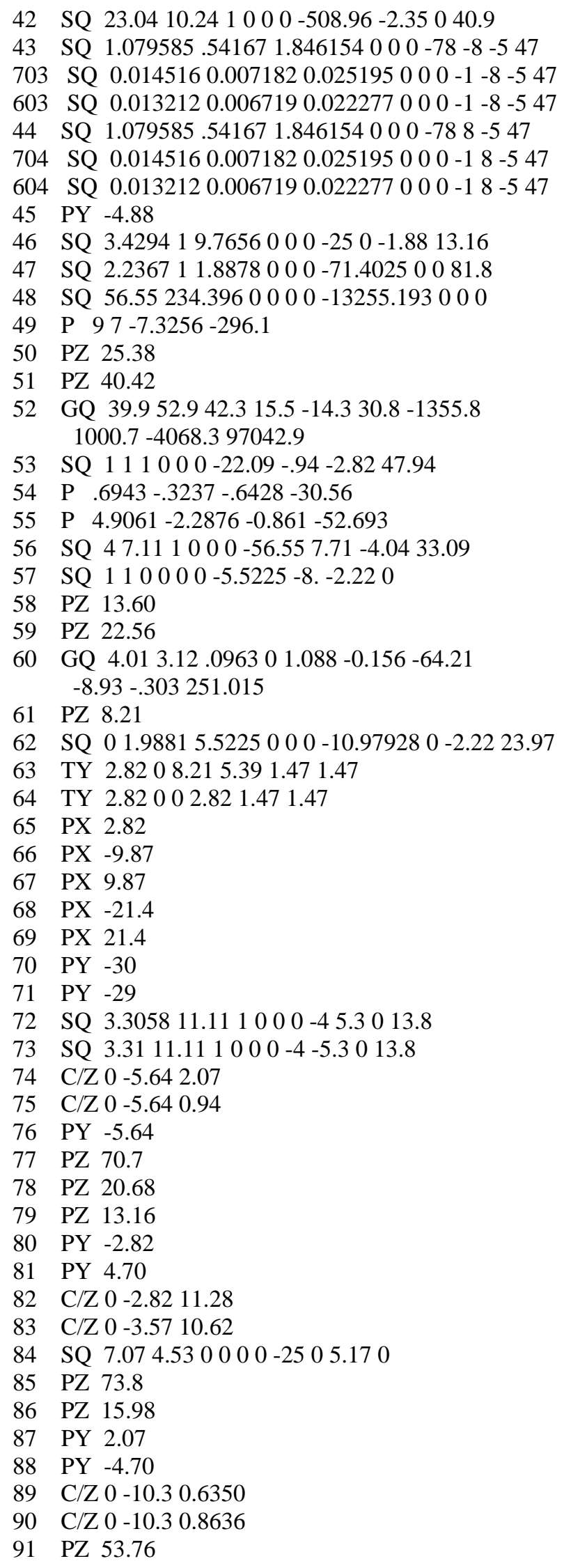




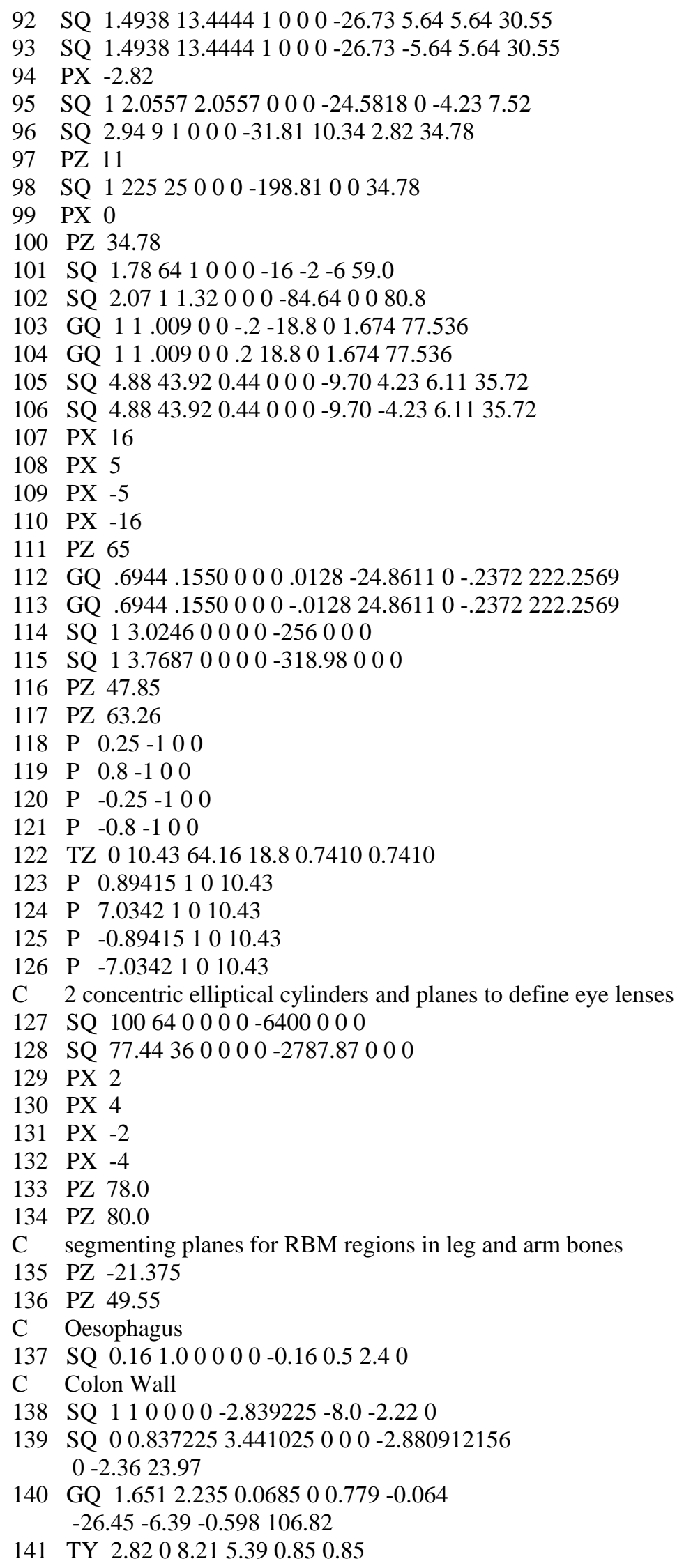


142 TY 2.82002 .820 .850 .85

C Abdomen Adipose

143 SQ $11.05060 .9879000-268.95700-6.916 .5$

713 SQ $0.0038100 .0040060 .0037640000-100-6.916 .5$

613 SQ $0.0036290 .0038100 .003586000-10-6.916 .5$

$\operatorname{tr} 600-0.1$

tr601 0.1

$\mathrm{C}$

C Source Cards

SDEF PAR=2 ERG=D1 CEL=600 POS $00-80.5$

$\mathrm{RAD}=\mathrm{D} 3 \mathrm{EXT}=\mathrm{D} 4 \mathrm{EFF}=1 \mathrm{E}-4 \mathrm{AXS} 0001$

C Sr-90/Y-90 SDEF

SI1 00.00010 .000110 .000120 .000130 .000140 .00015

$\begin{array}{llllll}0.00016 & 0.00018 & 0.0002 & 0.00022 & 0.00024 & 0.00026\end{array}$

$\begin{array}{lllllll}0.00028 & 0.0003 & 0.00032 & 0.00036 & 0.0004 & 0.00045\end{array}$

$\begin{array}{lllllll}0.0005 & 0.00055 & 0.0006 & 0.00065 & 0.0007 & 0.00075\end{array}$

$\begin{array}{lllllll}0.0008 & 0.00085 & 0.0009 & 0.001 & 0.0011 & 0.0012\end{array}$

$\begin{array}{lllllll}0.0013 & 0.0014 & 0.0015 & 0.0016 & 0.0018 & 0.002\end{array}$

$\begin{array}{llllll}0.0022 & 0.0024 & 0.0026 & 0.0028 & 0.003 & 0.0032\end{array}$

$\begin{array}{lllllll}0.0036 & 0.004 & 0.0045 & 0.005 & 0.0055 & 0.006\end{array}$

$\begin{array}{lllllll}0.0065 & 0.007 & 0.0075 & 0.008 & 0.0085 & 0.009\end{array}$

$\begin{array}{llllll}0.01 & 0.011 & 0.012 & 0.013 & 0.014 & 0.015\end{array}$

$\begin{array}{lllllll}0.016 & 0.018 & 0.02 & 0.022 & 0.024 & 0.026\end{array}$

$\begin{array}{llllll}0.028 & 0.03 & 0.032 & 0.036 & 0.04 & 0.045\end{array}$

$\begin{array}{llllll}0.05 & 0.055 & 0.06 & 0.065 & 0.07 & 0.075\end{array}$

$\begin{array}{llllll}0.08 & 0.085 & 0.09 & 0.1 & 0.11 & 0.12\end{array}$

$\begin{array}{llllll}0.13 & 0.14 & 0.15 & 0.16 & 0.18 & 0.2\end{array}$

$\begin{array}{llllll}0.22 & 0.24 & 0.26 & 0.28 & 0.3 & 0.32\end{array}$

$\begin{array}{llllll}0.36 & 0.4 & 0.45 & 0.5 & 0.55 & 0.6\end{array}$

$\begin{array}{llllll}0.65 & 0.7 & 0.75 & 0.8 & 0.85 & 0.9\end{array}$

$\begin{array}{llllll}1 & 1.1 & 1.2 & 1.3 & 1.4 & 1.5\end{array}$

$\begin{array}{lllll}1.6 & 1.8 & 2 & 2.2 & 2.28399992\end{array}$

SP1 03.2878999713 .2858998783 .2858998783 .2858998783 .285899878

3.284899953 .2849999673 .2849999673 .2849999673 .284999967

3.2840000393 .2840000393 .2840000393 .2830001123 .283000112 3.2830001123 .2819999463 .2810000183 .2810000183 .280000091 3.2789999253 .2779999973 .2779999973 .277000073 .275999904 3.2749999763 .2749999763 .2740000493 .2719999553 .271000028 3.2689999343 .2680000073 .2659999133 .2649999863 .263100117 3.2601000963 .2571000753 .2541000553 .2511000343 .248100013 3.2450999923 .2421999573 .2391999363 .2331998943 .227200091 3.2192999723 .2123000033 .2043001063 .2034999433 .201800078 3.2010999023 .1994000673 .1987999083 .1980999713 .196400106 3.1950000233 .1926000123 .1901999713 .187799963 .18539995 3.1841000913 .1817000513 .1778999573 .1731998923 .169400036 3.1667000653 .1629999583 .1603000163 .1565999093 .153899938 3.1496999863 .1455000043 .1399999563 .1365999883 .133300006 3.1300000553 .1277000013 .124400023 .1221999823 .119899958 3.1176998913 .1154001063 .1099000873 .1042000653 .097499907 3.0887001163 .0798000693 .0687999433 .0556999743 .022999972 2.9806998972 .9258999822 .8576000632 .7745999692 .675100088 2.5590999132 .4243999722 .1035000091 .72451 .216499984 0.7806000110 .6089000110 .6169000270 .6226000190 .626299977 0.6280999780 .6281999950 .6266000270 .6236000060 .613300025 0.5972999930 .5752999780 .5465000270 .5101000070 .465299994 


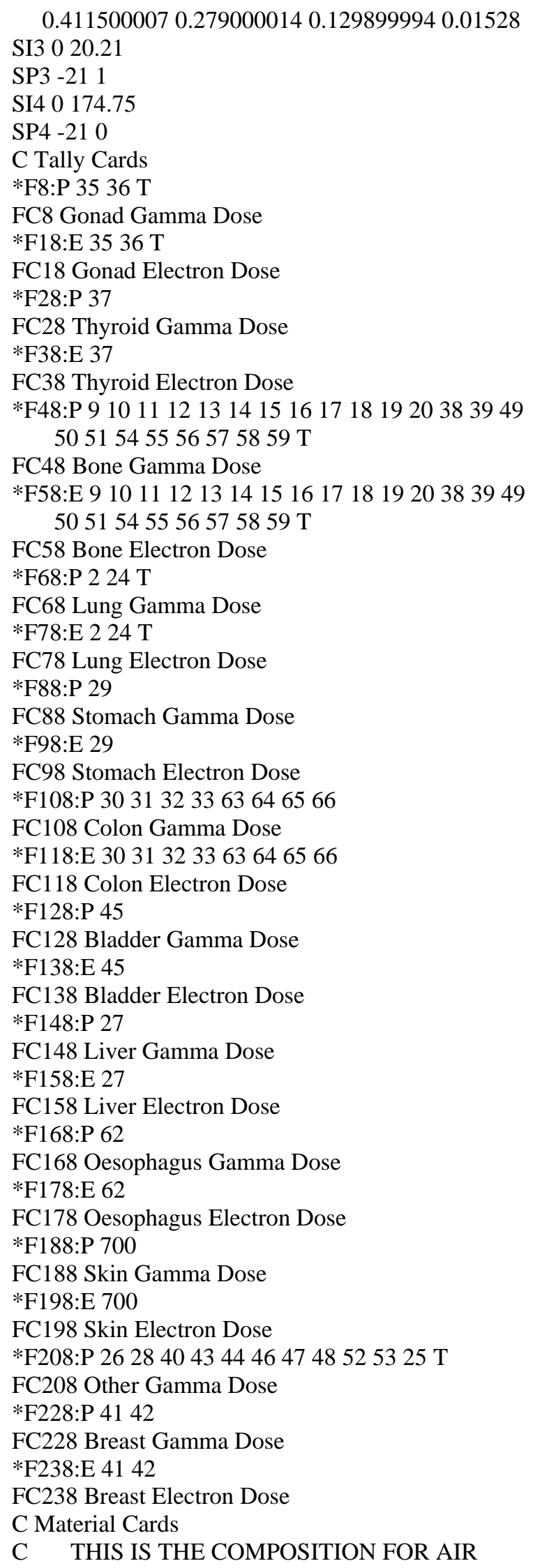




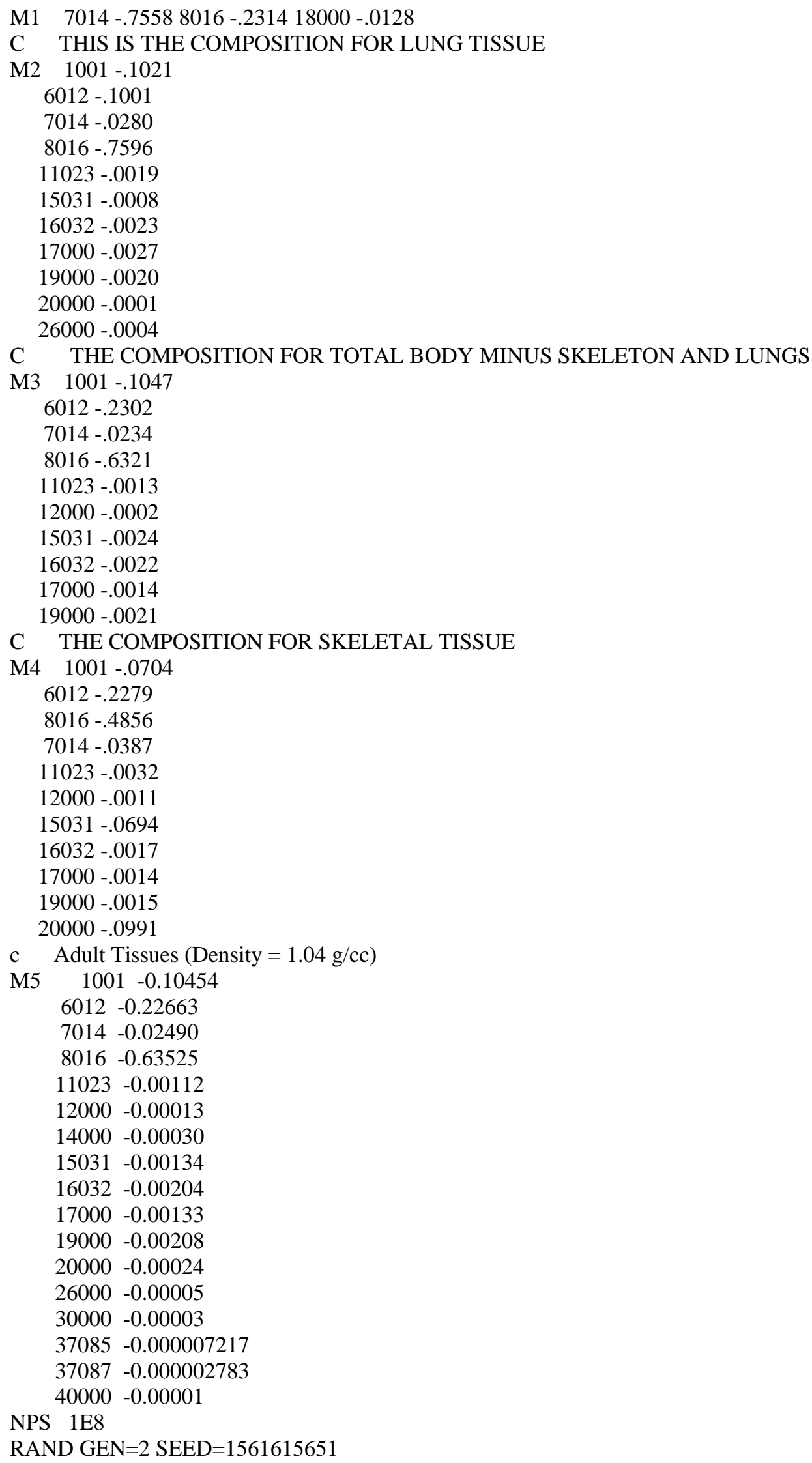


phys:p 4J 1

PRINT

MODE P E 


\section{APPENDIX H}

\section{EFFECTIVE DOSE CONTRIBUTION BY ORGAN TO PATIENT}

Table H.1 Effective Dose Contribution by Organ to Reference Male Patient for $37 \mathrm{GBq} / \mathrm{m}^{2}$ Surface Contamination $(\mathrm{mSv} / \mathrm{hr})$

\begin{tabular}{|l|c|c|c|c|c|}
\hline Organ & ${ }^{\mathbf{6 0}} \mathbf{C o}$ & ${ }^{192} \mathbf{I r}$ & ${ }^{241} \mathbf{A m}$ & ${ }^{137} \mathbf{C s}$ & ${ }^{131} \mathbf{I}$ \\
\hline \hline Gonads & $3.11 \mathrm{E}+01$ & $1.23 \mathrm{E}+01$ & $5.86 \mathrm{E}-01$ & $7.90 \mathrm{E}+00$ & $4.60 \mathrm{E}+00$ \\
\hline Stomach & $3.14 \mathrm{E}+01$ & $1.15 \mathrm{E}+01$ & $2.71 \mathrm{E}-01$ & $7.55 \mathrm{E}+00$ & $4.34 \mathrm{E}+00$ \\
\hline Colon Wall & $4.03 \mathrm{E}+01$ & $1.50 \mathrm{E}+01$ & $3.32 \mathrm{E}-01$ & $9.78 \mathrm{E}+00$ & $5.62 \mathrm{E}+00$ \\
\hline Bladder & $2.44 \mathrm{E}+01$ & $9.21 \mathrm{E}+00$ & $2.25 \mathrm{E}-01$ & $5.94 \mathrm{E}+00$ & $3.44 \mathrm{E}+00$ \\
\hline Lungs & $1.30 \mathrm{E}+01$ & $4.96 \mathrm{E}+00$ & $1.27 \mathrm{E}-01$ & $3.20 \mathrm{E}+00$ & $1.86 \mathrm{E}+00$ \\
\hline Bone & $2.38 \mathrm{E}+01$ & $9.82 \mathrm{E}+00$ & $6.69 \mathrm{E}-01$ & $5.96 \mathrm{E}+00$ & $3.57 \mathrm{E}+00$ \\
\hline Liver & $4.99 \mathrm{E}+00$ & $1.85 \mathrm{E}+00$ & $4.34 \mathrm{E}-02$ & $1.21 \mathrm{E}+00$ & $6.94 \mathrm{E}-01$ \\
\hline Thyroid & $1.01 \mathrm{E}+01$ & $3.88 \mathrm{E}+00$ & $1.18 \mathrm{E}-01$ & $2.52 \mathrm{E}+00$ & $1.46 \mathrm{E}+00$ \\
\hline Esophagus & $4.69 \mathrm{E}+00$ & $1.76 \mathrm{E}+00$ & $3.44 \mathrm{E}-02$ & $1.15 \mathrm{E}+00$ & $6.66 \mathrm{E}-01$ \\
\hline Skin & $1.33 \mathrm{E}+00$ & $6.53 \mathrm{E}-01$ & $1.07 \mathrm{E}-01$ & $4.00 \mathrm{E}-01$ & $2.46 \mathrm{E}-01$ \\
\hline Other & $1.20 \mathrm{E}+01$ & $4.58 \mathrm{E}+00$ & $1.04 \mathrm{E}-01$ & $2.98 \mathrm{E}+00$ & $1.71 \mathrm{E}+00$ \\
\hline Total & $1.97 \mathrm{E}+02$ & $7.55 \mathrm{E}+01$ & $2.61 \mathrm{E}+00$ & $4.86 \mathrm{E}+01$ & $2.82 \mathrm{E}+01$ \\
\hline
\end{tabular}

Table H.2 Effective Dose Contribution by Organ to Reference Female Patient for $37 \mathrm{GBq} / \mathrm{m}^{2}$ Surface Contamination $(\mathrm{mSv} / \mathrm{hr})$

\begin{tabular}{|l|c|c|c|c|c|}
\hline Organ & ${ }^{\mathbf{6 0}} \mathbf{C o}$ & ${ }^{{ }^{192}} \mathbf{I r}$ & ${ }^{\mathbf{2 4 1}} \mathbf{A m}$ & ${ }^{{ }^{137} \mathbf{C s}}$ & ${ }^{{ }^{131}} \mathbf{I}$ \\
\hline \hline Gonads & $1.42 \mathrm{E}+01$ & $5.24 \mathrm{E}+00$ & $9.42 \mathrm{E}-02$ & $3.36 \mathrm{E}+00$ & $1.96 \mathrm{E}+00$ \\
\hline Stomach & $2.51 \mathrm{E}+01$ & $9.46 \mathrm{E}+00$ & $2.20 \mathrm{E}-01$ & $6.11 \mathrm{E}+00$ & $3.54 \mathrm{E}+00$ \\
\hline Colon Wall & $2.97 \mathrm{E}+01$ & $1.10 \mathrm{E}+01$ & $2.35 \mathrm{E}-01$ & $7.12 \mathrm{E}+00$ & $4.11 \mathrm{E}+00$ \\
\hline Bladder & $2.01 \mathrm{E}+01$ & $7.57 \mathrm{E}+00$ & $1.61 \mathrm{E}-01$ & $4.85 \mathrm{E}+00$ & $2.82 \mathrm{E}+00$ \\
\hline Lungs & $1.19 \mathrm{E}+01$ & $4.59 \mathrm{E}+00$ & $1.14 \mathrm{E}-01$ & $2.94 \mathrm{E}+00$ & $1.72 \mathrm{E}+00$ \\
\hline Bone & $2.49 \mathrm{E}+01$ & $1.05 \mathrm{E}+01$ & $6.11 \mathrm{E}-01$ & $6.27 \mathrm{E}+00$ & $3.79 \mathrm{E}+00$ \\
\hline Liver & $4.47 \mathrm{E}+00$ & $1.68 \mathrm{E}+00$ & $3.84 \mathrm{E}-02$ & $1.08 \mathrm{E}+00$ & $6.27 \mathrm{E}-01$ \\
\hline Thyroid & $8.42 \mathrm{E}+00$ & $3.24 \mathrm{E}+00$ & $1.03 \mathrm{E}-01$ & $2.10 \mathrm{E}+00$ & $1.23 \mathrm{E}+00$ \\
\hline Esophagus & $5.51 \mathrm{E}+00$ & $2.09 \mathrm{E}+00$ & $4.13 \mathrm{E}-02$ & $1.34 \mathrm{E}+00$ & $7.82 \mathrm{E}-01$ \\
\hline Skin & $2.12 \mathrm{E}+00$ & $1.03 \mathrm{E}+00$ & $1.61 \mathrm{E}-01$ & $6.29 \mathrm{E}-01$ & $3.86 \mathrm{E}-01$ \\
\hline Other & $5.45 \mathrm{E}+00$ & $2.06 \mathrm{E}+00$ & $4.38 \mathrm{E}-02$ & $1.33 \mathrm{E}+00$ & $7.73 \mathrm{E}-01$ \\
\hline Breast & $2.15 \mathrm{E}+01$ & $8.51 \mathrm{E}+00$ & $4.80 \mathrm{E}-01$ & $5.47 \mathrm{E}+00$ & $3.21 \mathrm{E}+00$ \\
\hline Total & $1.73 \mathrm{E}+02$ & $6.70 \mathrm{E}+01$ & $2.30 \mathrm{E}+00$ & $4.26 \mathrm{E}+01$ & $2.49 \mathrm{E}+01$ \\
\hline
\end{tabular}


Table H.3 Effective Dose Contribution by Organ to Adipose Male Patient for $37 \mathrm{GBq} / \mathrm{m}^{2}$ Surface Contamination $(\mathrm{mSv} / \mathrm{hr})$

\begin{tabular}{|l|c|c|c|c|c|}
\hline Organ & ${ }^{\mathbf{6 0}} \mathbf{C o}$ & ${ }^{192} \mathbf{I r}$ & ${ }^{{ }^{\mathbf{4 1 1}} \mathbf{A m}}$ & ${ }^{137} \mathbf{C s}$ & ${ }^{131} \mathbf{I}$ \\
\hline \hline Gonads & $4.42 \mathrm{E}+01$ & $1.79 \mathrm{E}+01$ & $8.94 \mathrm{E}-01$ & $1.13 \mathrm{E}+01$ & $6.70 \mathrm{E}+00$ \\
\hline Stomach & $2.40 \mathrm{E}+01$ & $8.96 \mathrm{E}+00$ & $1.95 \mathrm{E}-01$ & $5.78 \mathrm{E}+00$ & $3.35 \mathrm{E}+00$ \\
\hline Colon & $3.31 \mathrm{E}+01$ & $1.22 \mathrm{E}+01$ & $2.38 \mathrm{E}-01$ & $7.86 \mathrm{E}+00$ & $4.53 \mathrm{E}+00$ \\
\hline Bladder & $2.04 \mathrm{E}+01$ & $7.67 \mathrm{E}+00$ & $1.56 \mathrm{E}-01$ & $4.89 \mathrm{E}+00$ & $2.85 \mathrm{E}+00$ \\
\hline Lungs & $1.08 \mathrm{E}+01$ & $4.17 \mathrm{E}+00$ & $1.00 \mathrm{E}-01$ & $2.67 \mathrm{E}+00$ & $1.56 \mathrm{E}+00$ \\
\hline Bone & $2.78 \mathrm{E}+01$ & $1.19 \mathrm{E}+01$ & $6.48 \mathrm{E}-01$ & $7.00 \mathrm{E}+00$ & $4.26 \mathrm{E}+00$ \\
\hline Liver & $3.75 \mathrm{E}+00$ & $1.39 \mathrm{E}+00$ & $2.99 \mathrm{E}-02$ & $9.02 \mathrm{E}-01$ & $5.19 \mathrm{E}-01$ \\
\hline Thyroid & $1.14 \mathrm{E}+01$ & $4.48 \mathrm{E}+00$ & $1.39 \mathrm{E}-01$ & $2.87 \mathrm{E}+00$ & $1.68 \mathrm{E}+00$ \\
\hline Esophagus & $4.44 \mathrm{E}+00$ & $1.68 \mathrm{E}+00$ & $3.26 \mathrm{E}-02$ & $1.08 \mathrm{E}+00$ & $6.27 \mathrm{E}-01$ \\
\hline Skin & $1.76 \mathrm{E}+00$ & $8.42 \mathrm{E}-01$ & $1.32 \mathrm{E}-01$ & $5.18 \mathrm{E}-01$ & $3.17 \mathrm{E}-01$ \\
\hline Other & $5.64 \mathrm{E}+00$ & $2.13 \mathrm{E}+00$ & $5.15 \mathrm{E}-02$ & $1.38 \mathrm{E}+00$ & $8.01 \mathrm{E}-01$ \\
\hline Breasts & $1.21 \mathrm{E}+01$ & $4.83 \mathrm{E}+00$ & $3.28 \mathrm{E}-01$ & $3.11 \mathrm{E}+00$ & $1.83 \mathrm{E}+00$ \\
\hline Total & $1.99 \mathrm{E}+02$ & $7.81 \mathrm{E}+01$ & $2.94 \mathrm{E}+00$ & $4.93 \mathrm{E}+01$ & $2.90 \mathrm{E}+01$ \\
\hline
\end{tabular}

Table H.4 Effective Dose Contribution by Organ to Adipose Female Patient for $37 \mathrm{GBq} / \mathrm{m}^{2}$ Surface Contamination $(\mathrm{mSv} / \mathrm{hr})$

\begin{tabular}{|l|c|c|c|c|c|}
\hline Organ & ${ }^{\mathbf{6 0}} \mathbf{C o}$ & ${ }^{\mathbf{1 9 2}} \mathbf{I r}$ & ${ }^{\mathbf{2 4 1}} \mathbf{A m}$ & ${ }^{\mathbf{1 3 7}} \mathbf{C s}$ & ${ }^{{ }^{311}} \mathbf{I}$ \\
\hline \hline Gonads & $1.42 \mathrm{E}+01$ & $5.24 \mathrm{E}+00$ & $9.42 \mathrm{E}-02$ & $3.36 \mathrm{E}+00$ & $1.96 \mathrm{E}+00$ \\
\hline Stomach & $2.51 \mathrm{E}+01$ & $9.46 \mathrm{E}+00$ & $2.20 \mathrm{E}-01$ & $6.11 \mathrm{E}+00$ & $3.54 \mathrm{E}+00$ \\
\hline Colon Wall & $2.97 \mathrm{E}+01$ & $1.10 \mathrm{E}+01$ & $2.35 \mathrm{E}-01$ & $7.12 \mathrm{E}+00$ & $4.11 \mathrm{E}+00$ \\
\hline Bladder & $2.01 \mathrm{E}+01$ & $7.57 \mathrm{E}+00$ & $1.61 \mathrm{E}-01$ & $4.85 \mathrm{E}+00$ & $2.82 \mathrm{E}+00$ \\
\hline Lungs & $1.19 \mathrm{E}+01$ & $4.59 \mathrm{E}+00$ & $1.14 \mathrm{E}-01$ & $2.94 \mathrm{E}+00$ & $1.72 \mathrm{E}+00$ \\
\hline Bone & $2.49 \mathrm{E}+01$ & $1.05 \mathrm{E}+01$ & $6.11 \mathrm{E}-01$ & $6.27 \mathrm{E}+00$ & $3.79 \mathrm{E}+00$ \\
\hline Liver & $4.47 \mathrm{E}+00$ & $1.68 \mathrm{E}+00$ & $3.84 \mathrm{E}-02$ & $1.08 \mathrm{E}+00$ & $6.27 \mathrm{E}-01$ \\
\hline Thyroid & $8.42 \mathrm{E}+00$ & $3.24 \mathrm{E}+00$ & $1.03 \mathrm{E}-01$ & $2.10 \mathrm{E}+00$ & $1.23 \mathrm{E}+00$ \\
\hline Esophagus & $5.51 \mathrm{E}+00$ & $2.09 \mathrm{E}+00$ & $4.13 \mathrm{E}-02$ & $1.34 \mathrm{E}+00$ & $7.82 \mathrm{E}-01$ \\
\hline Skin & $2.12 \mathrm{E}+00$ & $1.03 \mathrm{E}+00$ & $1.61 \mathrm{E}-01$ & $6.29 \mathrm{E}-01$ & $3.86 \mathrm{E}-01$ \\
\hline Other & $5.45 \mathrm{E}+00$ & $2.06 \mathrm{E}+00$ & $4.38 \mathrm{E}-02$ & $1.33 \mathrm{E}+00$ & $7.73 \mathrm{E}-01$ \\
\hline Breast & $2.15 \mathrm{E}+01$ & $8.51 \mathrm{E}+00$ & $4.80 \mathrm{E}-01$ & $5.47 \mathrm{E}+00$ & $3.21 \mathrm{E}+00$ \\
\hline Total & $1.73 \mathrm{E}+02$ & $6.70 \mathrm{E}+01$ & $2.30 \mathrm{E}+00$ & $4.26 \mathrm{E}+01$ & $2.49 \mathrm{E}+01$ \\
\hline
\end{tabular}


Table H.5 Effective Dose Contribution by Organ to Postmenopausal Adipose Female Patient for $37 \mathrm{GBq} / \mathrm{m}^{2}$ Surface Contamination $(\mathrm{mSv} / \mathrm{hr})$

\begin{tabular}{|l|c|c|c|c|c|}
\hline Organ & ${ }^{\mathbf{6 0}} \mathbf{C o}$ & ${ }^{192} \mathbf{I r}$ & ${ }^{{ }^{\mathbf{4 4 1}} \mathbf{A m}}$ & ${ }^{137} \mathbf{C s}$ & ${ }^{131} \mathbf{I}$ \\
\hline \hline Gonads & $2.71 \mathrm{E}+01$ & $1.03 \mathrm{E}+01$ & $1.54 \mathrm{E}-01$ & $6.37 \mathrm{E}+00$ & $3.73 \mathrm{E}+00$ \\
\hline Stomach & $2.24 \mathrm{E}+01$ & $8.47 \mathrm{E}+00$ & $1.92 \mathrm{E}-01$ & $5.44 \mathrm{E}+00$ & $3.17 \mathrm{E}+00$ \\
\hline Colon & $2.68 \mathrm{E}+01$ & $9.90 \mathrm{E}+00$ & $2.10 \mathrm{E}-01$ & $6.42 \mathrm{E}+00$ & $3.71 \mathrm{E}+00$ \\
\hline Bladder & $1.83 \mathrm{E}+01$ & $6.91 \mathrm{E}+00$ & $1.47 \mathrm{E}-01$ & $4.41 \mathrm{E}+00$ & $2.57 \mathrm{E}+00$ \\
\hline Lungs & $1.13 \mathrm{E}+01$ & $4.36 \mathrm{E}+00$ & $1.05 \mathrm{E}-01$ & $2.78 \mathrm{E}+00$ & $1.63 \mathrm{E}+00$ \\
\hline Bone & $2.44 \mathrm{E}+01$ & $1.05 \mathrm{E}+01$ & $5.85 \mathrm{E}-01$ & $6.14 \mathrm{E}+00$ & $3.74 \mathrm{E}+00$ \\
\hline Liver & $4.04 \mathrm{E}+00$ & $1.51 \mathrm{E}+00$ & $3.32 \mathrm{E}-02$ & $9.76 \mathrm{E}-01$ & $5.65 \mathrm{E}-01$ \\
\hline Thyroid & $1.37 \mathrm{E}+01$ & $5.37 \mathrm{E}+00$ & $1.72 \mathrm{E}-01$ & $3.43 \mathrm{E}+00$ & $2.01 \mathrm{E}+00$ \\
\hline Esophagus & $5.47 \mathrm{E}+00$ & $2.10 \mathrm{E}+00$ & $4.03 \mathrm{E}-02$ & $1.33 \mathrm{E}+00$ & $7.69 \mathrm{E}-01$ \\
\hline Skin & $1.87 \mathrm{E}+00$ & $9.11 \mathrm{E}-01$ & $1.45 \mathrm{E}-01$ & $5.57 \mathrm{E}-01$ & $3.42 \mathrm{E}-01$ \\
\hline Other & $5.32 \mathrm{E}+00$ & $2.01 \mathrm{E}+00$ & $4.22 \mathrm{E}-02$ & $1.30 \mathrm{E}+00$ & $7.49 \mathrm{E}-01$ \\
\hline Breast & $2.02 \mathrm{E}+01$ & $8.04 \mathrm{E}+00$ & $4.67 \mathrm{E}-01$ & $5.14 \mathrm{E}+00$ & $3.03 \mathrm{E}+00$ \\
\hline Total & $1.81 \mathrm{E}+02$ & $7.03 \mathrm{E}+01$ & $2.29 \mathrm{E}+00$ & $4.43 \mathrm{E}+01$ & $2.60 \mathrm{E}+01$ \\
\hline
\end{tabular}




\section{APPENDIX I}

\section{EFFECTIVE DOSE TO HEALTHCARE PROVIDER DUE TO EXTERNALLY CONTAMINATED PATIENT}

Table I.1 Effective Dose Contribution by Organ from Reference Male Patient to the Reference Male Healthcare Provider for $37 \mathrm{GBq} / \mathrm{m}^{2}$ Surface Contamination $(\mathrm{mSv} / \mathrm{hr})$

\begin{tabular}{|c|ccccc|}
\hline Organ & Co-60 & Ir-192 & Am-241 & Cs-137 & I-131 \\
\hline \hline Gonads & $2.58 \mathrm{E}+00$ & $8.77 \mathrm{E}-01$ & $1.46 \mathrm{E}-02$ & $5.95 \mathrm{E}-01$ & $3.17 \mathrm{E}-01$ \\
Stomach & $6.61 \mathrm{E}+00$ & $3.07 \mathrm{E}+00$ & $9.27 \mathrm{E}-02$ & $1.75 \mathrm{E}+00$ & $1.12 \mathrm{E}+00$ \\
Colon Wall & $8.56 \mathrm{E}+00$ & $3.76 \mathrm{E}+00$ & $9.81 \mathrm{E}-02$ & $2.19 \mathrm{E}+00$ & $1.38 \mathrm{E}+00$ \\
Bladder & $5.41 \mathrm{E}+00$ & $2.35 \mathrm{E}+00$ & $6.58 \mathrm{E}-02$ & $1.38 \mathrm{E}+00$ & $8.51 \mathrm{E}-01$ \\
Lungs & $1.59 \mathrm{E}+00$ & $6.61 \mathrm{E}-01$ & $1.80 \mathrm{E}-02$ & $4.05 \mathrm{E}-01$ & $2.44 \mathrm{E}-01$ \\
Bone & $2.13 \mathrm{E}+00$ & $8.99 \mathrm{E}-01$ & $4.69 \mathrm{E}-02$ & $5.26 \mathrm{E}-01$ & $3.22 \mathrm{E}-01$ \\
Liver & $8.97 \mathrm{E}-01$ & $3.96 \mathrm{E}-01$ & $1.13 \mathrm{E}-02$ & $2.34 \mathrm{E}-01$ & $1.46 \mathrm{E}-01$ \\
Thyroid & $9.09 \mathrm{E}-01$ & $3.85 \mathrm{E}-01$ & $1.10 \mathrm{E}-02$ & $2.34 \mathrm{E}-01$ & $1.43 \mathrm{E}-01$ \\
Esophagus & $4.54 \mathrm{E}-01$ & $1.65 \mathrm{E}-01$ & $2.81 \mathrm{E}-03$ & $1.03 \mathrm{E}-01$ & $6.25 \mathrm{E}-02$ \\
Skin & $9.98 \mathrm{E}-02$ & $4.24 \mathrm{E}-02$ & $5.15 \mathrm{E}-03$ & $2.61 \mathrm{E}-02$ & $1.57 \mathrm{E}-02$ \\
Other & $1.43 \mathrm{E}+00$ & $6.04 \mathrm{E}-01$ & $1.43 \mathrm{E}-02$ & $3.59 \mathrm{E}-01$ & $2.18 \mathrm{E}-01$ \\
\hline Total & $3.07 \mathrm{E}+01$ & $1.32 \mathrm{E}+01$ & $3.81 \mathrm{E}-01$ & $7.80 \mathrm{E}+00$ & $4.81 \mathrm{E}+00$ \\
\hline
\end{tabular}

Table I.2 Effective Dose Contribution by Organ from Reference Female Patient to the Reference Male Healthcare Provider for $37 \mathrm{GBq} / \mathrm{m}^{2}$ Surface Contamination $(\mathrm{mSv} / \mathrm{hr})$

\begin{tabular}{|c|ccccc|}
\hline Organ & Co-60 & Ir-192 & Am-241 & Cs-137 & I-131 \\
\hline \hline Gonads & $2.04 \mathrm{E}+00$ & $6.63 \mathrm{E}-01$ & $1.14 \mathrm{E}-02$ & $4.71 \mathrm{E}-01$ & $2.40 \mathrm{E}-01$ \\
Stomach & $5.57 \mathrm{E}+00$ & $2.60 \mathrm{E}+00$ & $7.93 \mathrm{E}-02$ & $1.49 \mathrm{E}+00$ & $9.51 \mathrm{E}-01$ \\
Colon Wall & $7.15 \mathrm{E}+00$ & $3.12 \mathrm{E}+00$ & $8.18 \mathrm{E}-02$ & $1.83 \mathrm{E}+00$ & $1.13 \mathrm{E}+00$ \\
Bladder & $4.54 \mathrm{E}+00$ & $1.92 \mathrm{E}+00$ & $5.44 \mathrm{E}-02$ & $1.15 \mathrm{E}+00$ & $7.12 \mathrm{E}-01$ \\
Lungs & $1.36 \mathrm{E}+00$ & $5.71 \mathrm{E}-01$ & $1.51 \mathrm{E}-02$ & $3.47 \mathrm{E}-01$ & $2.09 \mathrm{E}-01$ \\
Bone & $1.82 \mathrm{E}+00$ & $7.64 \mathrm{E}-01$ & $3.96 \mathrm{E}-02$ & $4.48 \mathrm{E}-01$ & $2.74 \mathrm{E}-01$ \\
Liver & $7.28 \mathrm{E}-01$ & $3.20 \mathrm{E}-01$ & $8.91 \mathrm{E}-03$ & $1.88 \mathrm{E}-01$ & $1.17 \mathrm{E}-01$ \\
Thyroid & $7.30 \mathrm{E}-01$ & $3.31 \mathrm{E}-01$ & $1.02 \mathrm{E}-02$ & $1.99 \mathrm{E}-01$ & $1.21 \mathrm{E}-01$ \\
Esophagus & $3.73 \mathrm{E}-01$ & $1.36 \mathrm{E}-01$ & $2.29 \mathrm{E}-03$ & $9.03 \mathrm{E}-02$ & $5.00 \mathrm{E}-02$ \\
Skin & $8.39 \mathrm{E}-02$ & $3.52 \mathrm{E}-02$ & $4.16 \mathrm{E}-03$ & $2.19 \mathrm{E}-02$ & $1.32 \mathrm{E}-02$ \\
Other & $1.19 \mathrm{E}+00$ & $5.08 \mathrm{E}-01$ & $1.19 \mathrm{E}-02$ & $3.10 \mathrm{E}-01$ & $1.88 \mathrm{E}-01$ \\
\hline Total & $2.56 \mathrm{E}+01$ & $1.10 \mathrm{E}+01$ & $3.19 \mathrm{E}-01$ & $6.55 \mathrm{E}+00$ & $4.01 \mathrm{E}+00$ \\
\hline
\end{tabular}


Table I.3 Effective Dose Contribution by Organ from Adipose Male Patient to the Reference Male Healthcare Provider for $37 \mathrm{GBq} / \mathrm{m}^{2}$ Surface Contamination $(\mathrm{mSv} / \mathrm{hr}$ )

\begin{tabular}{|c|ccccc|}
\hline Organ & Co-60 & Ir-192 & Am-241 & Cs-137 & I-131 \\
\hline \hline Gonads & $2.76 \mathrm{E}+00$ & $9.07 \mathrm{E}-01$ & $1.75 \mathrm{E}-02$ & $6.31 \mathrm{E}-01$ & $3.36 \mathrm{E}-01$ \\
Stomach & $6.83 \mathrm{E}+00$ & $3.05 \mathrm{E}+00$ & $8.65 \mathrm{E}-02$ & $1.78 \mathrm{E}+00$ & $1.12 \mathrm{E}+00$ \\
Colon Wall & $8.87 \mathrm{E}+00$ & $3.70 \mathrm{E}+00$ & $9.03 \mathrm{E}-02$ & $2.21 \mathrm{E}+00$ & $1.36 \mathrm{E}+00$ \\
Bladder & $6.14 \mathrm{E}+00$ & $2.57 \mathrm{E}+00$ & $6.99 \mathrm{E}-02$ & $1.56 \mathrm{E}+00$ & $9.50 \mathrm{E}-01$ \\
Lungs & $1.74 \mathrm{E}+00$ & $7.07 \mathrm{E}-01$ & $1.80 \mathrm{E}-02$ & $4.35 \mathrm{E}-01$ & $2.59 \mathrm{E}-01$ \\
Bone & $2.42 \mathrm{E}+00$ & $9.94 \mathrm{E}-01$ & $5.01 \mathrm{E}-02$ & $5.88 \mathrm{E}-01$ & $3.57 \mathrm{E}-01$ \\
Liver & $8.68 \mathrm{E}-01$ & $3.66 \mathrm{E}-01$ & $9.63 \mathrm{E}-03$ & $2.20 \mathrm{E}-01$ & $1.34 \mathrm{E}-01$ \\
Thyroid & $1.01 \mathrm{E}+00$ & $4.41 \mathrm{E}-01$ & $1.33 \mathrm{E}-02$ & $2.67 \mathrm{E}-01$ & $1.60 \mathrm{E}-01$ \\
Esophagus & $5.09 \mathrm{E}-01$ & $1.72 \mathrm{E}-01$ & $3.01 \mathrm{E}-03$ & $1.11 \mathrm{E}-01$ & $6.50 \mathrm{E}-02$ \\
Skin & $1.09 \mathrm{E}-01$ & $4.40 \mathrm{E}-02$ & $4.73 \mathrm{E}-03$ & $2.77 \mathrm{E}-02$ & $1.64 \mathrm{E}-02$ \\
Other & $1.49 \mathrm{E}+00$ & $5.85 \mathrm{E}-01$ & $1.42 \mathrm{E}-02$ & $3.80 \mathrm{E}-01$ & $2.28 \mathrm{E}-01$ \\
\hline Total & $3.27 \mathrm{E}+01$ & $1.35 \mathrm{E}+01$ & $3.77 \mathrm{E}-01$ & $8.22 \mathrm{E}+00$ & $4.98 \mathrm{E}+00$ \\
\hline
\end{tabular}

Table I.4 Effective Dose Contribution by Organ from Adipose Female Patient to the Reference Male Healthcare Provider for $37 \mathrm{GBq} / \mathrm{m}^{2}$ Surface Contamination $(\mathrm{mSv} / \mathrm{hr})$

\begin{tabular}{|c|ccccc|}
\hline Organ & Co-60 & Ir-192 & Am-241 & Cs-137 & I-131 \\
\hline \hline Gonads & $2.62 \mathrm{E}+00$ & $8.04 \mathrm{E}-01$ & $1.59 \mathrm{E}-02$ & $6.03 \mathrm{E}-01$ & $3.32 \mathrm{E}-01$ \\
Stomach & $6.87 \mathrm{E}+00$ & $3.13 \mathrm{E}+00$ & $9.67 \mathrm{E}-02$ & $1.80 \mathrm{E}+00$ & $1.14 \mathrm{E}+00$ \\
Colon Wall & $8.58 \mathrm{E}+00$ & $3.76 \mathrm{E}+00$ & $9.67 \mathrm{E}-02$ & $2.21 \mathrm{E}+00$ & $1.36 \mathrm{E}+00$ \\
Bladder & $5.38 \mathrm{E}+00$ & $2.34 \mathrm{E}+00$ & $6.65 \mathrm{E}-02$ & $1.39 \mathrm{E}+00$ & $8.68 \mathrm{E}-01$ \\
Lungs & $1.66 \mathrm{E}+00$ & $6.98 \mathrm{E}-01$ & $1.87 \mathrm{E}-02$ & $4.25 \mathrm{E}-01$ & $2.55 \mathrm{E}-01$ \\
Bone & $2.22 \mathrm{E}+00$ & $9.29 \mathrm{E}-01$ & $4.85 \mathrm{E}-02$ & $5.44 \mathrm{E}-01$ & $3.32 \mathrm{E}-01$ \\
Liver & $8.74 \mathrm{E}-01$ & $3.77 \mathrm{E}-01$ & $1.05 \mathrm{E}-02$ & $2.24 \mathrm{E}-01$ & $1.39 \mathrm{E}-01$ \\
Thyroid & $1.03 \mathrm{E}+00$ & $4.22 \mathrm{E}-01$ & $1.13 \mathrm{E}-02$ & $2.61 \mathrm{E}-01$ & $1.52 \mathrm{E}-01$ \\
Esophagus & $4.75 \mathrm{E}-01$ & $1.79 \mathrm{E}-01$ & $3.08 \mathrm{E}-03$ & $1.12 \mathrm{E}-01$ & $6.59 \mathrm{E}-02$ \\
Skin & $1.02 \mathrm{E}-01$ & $4.27 \mathrm{E}-02$ & $4.96 \mathrm{E}-03$ & $2.66 \mathrm{E}-02$ & $1.59 \mathrm{E}-02$ \\
Other & $1.48 \mathrm{E}+00$ & $5.99 \mathrm{E}-01$ & $1.32 \mathrm{E}-02$ & $3.66 \mathrm{E}-01$ & $2.24 \mathrm{E}-01$ \\
\hline Total & $3.13 \mathrm{E}+01$ & $1.33 \mathrm{E}+01$ & $3.86 \mathrm{E}-01$ & $7.96 \mathrm{E}+00$ & $4.88 \mathrm{E}+00$ \\
\hline
\end{tabular}


Table I.5 Effective Dose Contribution by Organ from Postmenopausal Adipose Female Patient to the Reference Male Healthcare Provider for $37 \mathrm{GBq} / \mathrm{m}^{2}$ Surface Contamination $(\mathrm{mSv} / \mathrm{hr})$

\begin{tabular}{|c|ccccc|}
\hline Organ & Co-60 & Ir-192 & Am-241 & Cs-137 & I-131 \\
\hline \hline Gonads & $2.58 \mathrm{E}+00$ & $8.46 \mathrm{E}-01$ & $1.60 \mathrm{E}-02$ & $5.87 \mathrm{E}-01$ & $3.17 \mathrm{E}-01$ \\
Stomach & $6.48 \mathrm{E}+00$ & $2.94 \mathrm{E}+00$ & $8.80 \mathrm{E}-02$ & $1.70 \mathrm{E}+00$ & $1.06 \mathrm{E}+00$ \\
Colon Wall & $8.30 \mathrm{E}+00$ & $3.57 \mathrm{E}+00$ & $9.04 \mathrm{E}-02$ & $2.14 \mathrm{E}+00$ & $1.31 \mathrm{E}+00$ \\
Bladder & $5.60 \mathrm{E}+00$ & $2.38 \mathrm{E}+00$ & $6.49 \mathrm{E}-02$ & $1.44 \mathrm{E}+00$ & $8.80 \mathrm{E}-01$ \\
Lungs & $1.63 \mathrm{E}+00$ & $6.65 \mathrm{E}-01$ & $1.75 \mathrm{E}-02$ & $4.07 \mathrm{E}-01$ & $2.45 \mathrm{E}-01$ \\
Bone & $2.20 \mathrm{E}+00$ & $9.17 \mathrm{E}-01$ & $4.71 \mathrm{E}-02$ & $5.38 \mathrm{E}-01$ & $3.28 \mathrm{E}-01$ \\
Liver & $8.33 \mathrm{E}-01$ & $3.58 \mathrm{E}-01$ & $9.78 \mathrm{E}-03$ & $2.14 \mathrm{E}-01$ & $1.32 \mathrm{E}-01$ \\
Thyroid & $9.56 \mathrm{E}-01$ & $4.01 \mathrm{E}-01$ & $1.14 \mathrm{E}-02$ & $2.50 \mathrm{E}-01$ & $1.53 \mathrm{E}-01$ \\
Esophagus & $4.52 \mathrm{E}-01$ & $1.64 \mathrm{E}-01$ & $3.13 \mathrm{E}-03$ & $1.06 \mathrm{E}-01$ & $6.25 \mathrm{E}-02$ \\
Skin & $1.00 \mathrm{E}-01$ & $4.14 \mathrm{E}-02$ & $4.63 \mathrm{E}-03$ & $2.60 \mathrm{E}-02$ & $1.54 \mathrm{E}-02$ \\
Other & $1.45 \mathrm{E}+00$ & $5.88 \mathrm{E}-01$ & $1.41 \mathrm{E}-02$ & $3.51 \mathrm{E}-01$ & $2.13 \mathrm{E}-01$ \\
\hline Total & $3.06 \mathrm{E}+01$ & $1.29 \mathrm{E}+01$ & $3.67 \mathrm{E}-01$ & $7.76 \mathrm{E}+00$ & $4.72 \mathrm{E}+00$ \\
\hline
\end{tabular}

Table I.6 Effective Dose Contribution by Organ from Reference Male Patient to the Reference Female Healthcare Provider for $37 \mathrm{GBq} / \mathrm{m}^{2}$ Surface Contamination $(\mathrm{mSv} / \mathrm{hr})$

\begin{tabular}{|c|ccccc|}
\hline Organ & Co-60 & Ir-192 & Am-241 & Cs-137 & I-131 \\
\hline \hline Gonads & $3.58 \mathrm{E}+00$ & $1.55 \mathrm{E}+00$ & $3.38 \mathrm{E}-02$ & $9.44 \mathrm{E}-01$ & $5.45 \mathrm{E}-01$ \\
Stomach & $6.17 \mathrm{E}+00$ & $2.90 \mathrm{E}+00$ & $9.20 \mathrm{E}-02$ & $1.64 \mathrm{E}+00$ & $1.05 \mathrm{E}+00$ \\
Colon Wall & $7.26 \mathrm{E}+00$ & $3.22 \mathrm{E}+00$ & $8.36 \mathrm{E}-02$ & $1.89 \mathrm{E}+00$ & $1.18 \mathrm{E}+00$ \\
Bladder & $5.26 \mathrm{E}+00$ & $2.25 \mathrm{E}+00$ & $6.25 \mathrm{E}-02$ & $1.32 \mathrm{E}+00$ & $8.21 \mathrm{E}-01$ \\
Lungs & $1.69 \mathrm{E}+00$ & $6.98 \mathrm{E}-01$ & $1.82 \mathrm{E}-02$ & $4.24 \mathrm{E}-01$ & $2.56 \mathrm{E}-01$ \\
Bone & $2.28 \mathrm{E}+00$ & $9.59 \mathrm{E}-01$ & $4.83 \mathrm{E}-02$ & $5.62 \mathrm{E}-01$ & $3.44 \mathrm{E}-01$ \\
Liver & $9.64 \mathrm{E}-01$ & $4.30 \mathrm{E}-01$ & $1.24 \mathrm{E}-02$ & $2.52 \mathrm{E}-01$ & $1.58 \mathrm{E}-01$ \\
Thyroid & $8.04 \mathrm{E}-01$ & $3.50 \mathrm{E}-01$ & $1.09 \mathrm{E}-02$ & $2.17 \mathrm{E}-01$ & $1.30 \mathrm{E}-01$ \\
Esophagus & $5.51 \mathrm{E}-01$ & $2.05 \mathrm{E}-01$ & $3.37 \mathrm{E}-03$ & $1.30 \mathrm{E}-01$ & $7.90 \mathrm{E}-02$ \\
Skin & $1.52 \mathrm{E}-01$ & $6.33 \mathrm{E}-02$ & $6.99 \mathrm{E}-03$ & $3.93 \mathrm{E}-02$ & $2.35 \mathrm{E}-02$ \\
Other & $7.97 \mathrm{E}-01$ & $3.32 \mathrm{E}-01$ & $7.44 \mathrm{E}-03$ & $2.03 \mathrm{E}-01$ & $1.17 \mathrm{E}-01$ \\
Breasts & $2.63 \mathrm{E}+00$ & $1.19 \mathrm{E}+00$ & $6.98 \mathrm{E}-02$ & $7.01 \mathrm{E}-01$ & $4.38 \mathrm{E}-01$ \\
\hline Total & $3.21 \mathrm{E}+01$ & $1.41 \mathrm{E}+01$ & $4.49 \mathrm{E}-01$ & $8.32 \mathrm{E}+00$ & $5.15 \mathrm{E}+00$ \\
\hline
\end{tabular}


Table I.7 Effective Dose Contribution by Organ from Reference Female Patient to the Reference Female Healthcare Provider for $37 \mathrm{GBq} / \mathrm{m}^{2}$ Surface Contamination $(\mathrm{mSv} / \mathrm{hr})$

\begin{tabular}{|c|ccccc|}
\hline Organ & Co-60 & Ir-192 & Am-241 & Cs-137 & I-131 \\
\hline \hline Gonads & $3.17 \mathrm{E}+00$ & $1.23 \mathrm{E}+00$ & $2.85 \mathrm{E}-02$ & $8.13 \mathrm{E}-01$ & $4.74 \mathrm{E}-01$ \\
Stomach & $5.18 \mathrm{E}+00$ & $2.45 \mathrm{E}+00$ & $7.75 \mathrm{E}-02$ & $1.40 \mathrm{E}+00$ & $8.90 \mathrm{E}-01$ \\
Colon Wall & $6.07 \mathrm{E}+00$ & $2.65 \mathrm{E}+00$ & $6.78 \mathrm{E}-02$ & $1.56 \mathrm{E}+00$ & $9.70 \mathrm{E}-01$ \\
Bladder & $4.44 \mathrm{E}+00$ & $1.87 \mathrm{E}+00$ & $5.17 \mathrm{E}-02$ & $1.13 \mathrm{E}+00$ & $6.88 \mathrm{E}-01$ \\
Lungs & $1.43 \mathrm{E}+00$ & $5.91 \mathrm{E}-01$ & $1.52 \mathrm{E}-02$ & $3.63 \mathrm{E}-01$ & $2.18 \mathrm{E}-01$ \\
Bone & $1.94 \mathrm{E}+00$ & $8.14 \mathrm{E}-01$ & $4.09 \mathrm{E}-02$ & $4.77 \mathrm{E}-01$ & $2.91 \mathrm{E}-01$ \\
Liver & $7.71 \mathrm{E}-01$ & $3.45 \mathrm{E}-01$ & $9.70 \mathrm{E}-03$ & $2.02 \mathrm{E}-01$ & $1.26 \mathrm{E}-01$ \\
Thyroid & $7.18 \mathrm{E}-01$ & $2.99 \mathrm{E}-01$ & $1.03 \mathrm{E}-02$ & $1.87 \mathrm{E}-01$ & $1.12 \mathrm{E}-01$ \\
Esophagus & $4.92 \mathrm{E}-01$ & $1.89 \mathrm{E}-01$ & $3.21 \mathrm{E}-03$ & $1.21 \mathrm{E}-01$ & $6.93 \mathrm{E}-02$ \\
Skin & $1.28 \mathrm{E}-01$ & $5.25 \mathrm{E}-02$ & $5.66 \mathrm{E}-03$ & $3.31 \mathrm{E}-02$ & $1.97 \mathrm{E}-02$ \\
Other & $6.35 \mathrm{E}-01$ & $2.73 \mathrm{E}-01$ & $6.65 \mathrm{E}-03$ & $1.65 \mathrm{E}-01$ & $9.97 \mathrm{E}-02$ \\
Breasts & $2.23 \mathrm{E}+00$ & $1.00 \mathrm{E}+00$ & $5.68 \mathrm{E}-02$ & $5.93 \mathrm{E}-01$ & $3.70 \mathrm{E}-01$ \\
\hline Total & $2.72 \mathrm{E}+01$ & $1.18 \mathrm{E}+01$ & $3.74 \mathrm{E}-01$ & $7.05 \mathrm{E}+00$ & $4.33 \mathrm{E}+00$ \\
\hline
\end{tabular}

Table I.8 Effective Dose Contribution by Organ from Adipose Male Patient to the Reference Female Healthcare Provider for $37 \mathrm{GBq} / \mathrm{m}^{2}$ Surface Contamination $(\mathrm{mSv} / \mathrm{hr})$

\begin{tabular}{|c|ccccc|}
\hline Organ & Co-60 & Ir-192 & Am-241 & Cs-137 & I-131 \\
\hline \hline Gonads & $3.63 \mathrm{E}+00$ & $1.52 \mathrm{E}+00$ & $3.50 \mathrm{E}-02$ & $9.39 \mathrm{E}-01$ & $5.60 \mathrm{E}-01$ \\
Stomach & $6.23 \mathrm{E}+00$ & $2.83 \mathrm{E}+00$ & $8.52 \mathrm{E}-02$ & $1.64 \mathrm{E}+00$ & $1.04 \mathrm{E}+00$ \\
Colon Wall & $7.50 \mathrm{E}+00$ & $3.16 \mathrm{E}+00$ & $7.67 \mathrm{E}-02$ & $1.90 \mathrm{E}+00$ & $1.16 \mathrm{E}+00$ \\
Bladder & $6.05 \mathrm{E}+00$ & $2.52 \mathrm{E}+00$ & $6.63 \mathrm{E}-02$ & $1.53 \mathrm{E}+00$ & $9.35 \mathrm{E}-01$ \\
Lungs & $1.82 \mathrm{E}+00$ & $7.30 \mathrm{E}-01$ & $1.80 \mathrm{E}-02$ & $4.55 \mathrm{E}-01$ & $2.68 \mathrm{E}-01$ \\
Bone & $2.57 \mathrm{E}+00$ & $1.05 \mathrm{E}+00$ & $5.14 \mathrm{E}-02$ & $6.24 \mathrm{E}-01$ & $3.78 \mathrm{E}-01$ \\
Liver & $9.24 \mathrm{E}-01$ & $3.89 \mathrm{E}-01$ & $1.05 \mathrm{E}-02$ & $2.34 \mathrm{E}-01$ & $1.43 \mathrm{E}-01$ \\
Thyroid & $9.24 \mathrm{E}-01$ & $3.87 \mathrm{E}-01$ & $1.32 \mathrm{E}-02$ & $2.33 \mathrm{E}-01$ & $1.51 \mathrm{E}-01$ \\
Esophagus & $6.27 \mathrm{E}-01$ & $2.23 \mathrm{E}-01$ & $3.58 \mathrm{E}-03$ & $1.59 \mathrm{E}-01$ & $8.43 \mathrm{E}-02$ \\
Skin & $1.66 \mathrm{E}-01$ & $6.54 \mathrm{E}-02$ & $6.43 \mathrm{E}-03$ & $4.18 \mathrm{E}-02$ & $2.45 \mathrm{E}-02$ \\
Other & $8.13 \mathrm{E}-01$ & $3.37 \mathrm{E}-01$ & $7.30 \mathrm{E}-03$ & $2.07 \mathrm{E}-01$ & $1.21 \mathrm{E}-01$ \\
Breasts & $2.76 \mathrm{E}+00$ & $1.20 \mathrm{E}+00$ & $6.38 \mathrm{E}-02$ & $7.22 \mathrm{E}-01$ & $4.41 \mathrm{E}-01$ \\
\hline Total & $3.40 \mathrm{E}+01$ & $1.44 \mathrm{E}+01$ & $4.37 \mathrm{E}-01$ & $8.68 \mathrm{E}+00$ & $5.30 \mathrm{E}+00$ \\
\hline
\end{tabular}


Table I.9 Effective Dose Contribution by Organ from Adipose Female Patient to the Reference Female Healthcare Provider for $37 \mathrm{GBq} / \mathrm{m}^{2}$ Surface Contamination $(\mathrm{mSv} / \mathrm{hr})$

\begin{tabular}{|c|ccccc|}
\hline Organ & Co-60 & Ir-192 & Am-241 & Cs-137 & I-131 \\
\hline \hline Gonads & $3.53 \mathrm{E}+00$ & $1.45 \mathrm{E}+00$ & $3.51 \mathrm{E}-02$ & $8.66 \mathrm{E}-01$ & $5.71 \mathrm{E}-01$ \\
Stomach & $6.33 \mathrm{E}+00$ & $2.95 \mathrm{E}+00$ & $9.29 \mathrm{E}-02$ & $1.69 \mathrm{E}+00$ & $1.07 \mathrm{E}+00$ \\
Colon Wall & $7.40 \mathrm{E}+00$ & $3.23 \mathrm{E}+00$ & $8.18 \mathrm{E}-02$ & $1.91 \mathrm{E}+00$ & $1.18 \mathrm{E}+00$ \\
Bladder & $5.19 \mathrm{E}+00$ & $2.24 \mathrm{E}+00$ & $6.22 \mathrm{E}-02$ & $1.34 \mathrm{E}+00$ & $8.28 \mathrm{E}-01$ \\
Lungs & $1.74 \mathrm{E}+00$ & $7.14 \mathrm{E}-01$ & $1.83 \mathrm{E}-02$ & $4.38 \mathrm{E}-01$ & $2.63 \mathrm{E}-01$ \\
Bone & $2.35 \mathrm{E}+00$ & $9.88 \mathrm{E}-01$ & $5.00 \mathrm{E}-02$ & $5.78 \mathrm{E}-01$ & $3.53 \mathrm{E}-01$ \\
Liver & $9.34 \mathrm{E}-01$ & $4.09 \mathrm{E}-01$ & $1.17 \mathrm{E}-02$ & $2.41 \mathrm{E}-01$ & $1.50 \mathrm{E}-01$ \\
Thyroid & $9.17 \mathrm{E}-01$ & $3.72 \mathrm{E}-01$ & $1.28 \mathrm{E}-02$ & $2.31 \mathrm{E}-01$ & $1.42 \mathrm{E}-01$ \\
Esophagus & $5.68 \mathrm{E}-01$ & $2.09 \mathrm{E}-01$ & $3.89 \mathrm{E}-03$ & $1.38 \mathrm{E}-01$ & $7.88 \mathrm{E}-02$ \\
Skin & $1.55 \mathrm{E}-01$ & $6.38 \mathrm{E}-02$ & $6.75 \mathrm{E}-03$ & $4.00 \mathrm{E}-02$ & $2.37 \mathrm{E}-02$ \\
Other & $7.77 \mathrm{E}-01$ & $3.18 \mathrm{E}-01$ & $7.53 \mathrm{E}-03$ & $1.95 \mathrm{E}-01$ & $1.19 \mathrm{E}-01$ \\
Breasts & $2.72 \mathrm{E}+00$ & $1.22 \mathrm{E}+00$ & $6.79 \mathrm{E}-02$ & $7.20 \mathrm{E}-01$ & $4.47 \mathrm{E}-01$ \\
\hline Total & $3.26 \mathrm{E}+01$ & $1.42 \mathrm{E}+01$ & $4.51 \mathrm{E}-01$ & $8.39 \mathrm{E}+00$ & $5.22 \mathrm{E}+00$ \\
\hline
\end{tabular}

Table I.10 Effective Dose Contribution by Organ from Postmenopausal Adipose Female Patient to the Reference Female Healthcare Provider for $37 \mathrm{GBq} / \mathrm{m}^{2}$ Surface Contamination $(\mathrm{mSv} / \mathrm{hr})$

\begin{tabular}{|c|ccccc|}
\hline Organ & Co-60 & Ir-192 & Am-241 & Cs-137 & I-131 \\
\hline \hline Gonads & $3.50 \mathrm{E}+00$ & $1.42 \mathrm{E}+00$ & $3.38 \mathrm{E}-02$ & $8.92 \mathrm{E}-01$ & $5.44 \mathrm{E}-01$ \\
Stomach & $6.06 \mathrm{E}+00$ & $2.76 \mathrm{E}+00$ & $8.65 \mathrm{E}-02$ & $1.60 \mathrm{E}+00$ & $1.00 \mathrm{E}+00$ \\
Colon Wall & $7.18 \mathrm{E}+00$ & $3.08 \mathrm{E}+00$ & $7.69 \mathrm{E}-02$ & $1.86 \mathrm{E}+00$ & $1.12 \mathrm{E}+00$ \\
Bladder & $5.43 \mathrm{E}+00$ & $2.31 \mathrm{E}+00$ & $6.26 \mathrm{E}-02$ & $1.40 \mathrm{E}+00$ & $8.57 \mathrm{E}-01$ \\
Lungs & $1.68 \mathrm{E}+00$ & $6.79 \mathrm{E}-01$ & $1.71 \mathrm{E}-02$ & $4.20 \mathrm{E}-01$ & $2.51 \mathrm{E}-01$ \\
Bone & $2.34 \mathrm{E}+00$ & $9.72 \mathrm{E}-01$ & $4.82 \mathrm{E}-02$ & $5.72 \mathrm{E}-01$ & $3.48 \mathrm{E}-01$ \\
Liver & $8.82 \mathrm{E}-01$ & $3.86 \mathrm{E}-01$ & $1.07 \mathrm{E}-02$ & $2.28 \mathrm{E}-01$ & $1.42 \mathrm{E}-01$ \\
Thyroid & $8.79 \mathrm{E}-01$ & $3.65 \mathrm{E}-01$ & $1.17 \mathrm{E}-02$ & $2.36 \mathrm{E}-01$ & $1.34 \mathrm{E}-01$ \\
Esophagus & $5.88 \mathrm{E}-01$ & $2.13 \mathrm{E}-01$ & $3.83 \mathrm{E}-03$ & $1.44 \mathrm{E}-01$ & $7.89 \mathrm{E}-02$ \\
Skin & $1.52 \mathrm{E}-01$ & $6.18 \mathrm{E}-02$ & $6.31 \mathrm{E}-03$ & $3.90 \mathrm{E}-02$ & $2.30 \mathrm{E}-02$ \\
Other & $7.30 \mathrm{E}-01$ & $3.18 \mathrm{E}-01$ & $7.37 \mathrm{E}-03$ & $1.90 \mathrm{E}-01$ & $1.15 \mathrm{E}-01$ \\
Breasts & $2.59 \mathrm{E}+00$ & $1.15 \mathrm{E}+00$ & $6.24 \mathrm{E}-02$ & $6.81 \mathrm{E}-01$ & $4.22 \mathrm{E}-01$ \\
\hline Total & $3.20 \mathrm{E}+01$ & $1.37 \mathrm{E}+01$ & $4.27 \mathrm{E}-01$ & $8.26 \mathrm{E}+00$ & $5.04 \mathrm{E}+00$ \\
\hline
\end{tabular}


Table I.11 Effective Dose Contribution by Organ from Reference Male Patient to the Adipose Male Healthcare Provider for $37 \mathrm{GBq} / \mathrm{m}^{2}$ Surface Contamination $(\mathrm{mSv} / \mathrm{hr})$

\begin{tabular}{|c|ccccc|}
\hline Organ & Co-60 & Ir-192 & Am-241 & Cs-137 & I-131 \\
\hline \hline Gonads & $7.25 \mathrm{E}-01$ & $1.22 \mathrm{E}+00$ & $3.05 \mathrm{E}-02$ & $8.25 \mathrm{E}-01$ & $4.66 \mathrm{E}-01$ \\
Stomach & $1.29 \mathrm{E}+00$ & $2.18 \mathrm{E}+00$ & $5.01 \mathrm{E}-02$ & $1.32 \mathrm{E}+00$ & $7.94 \mathrm{E}-01$ \\
Colon Wall & $1.27 \mathrm{E}+00$ & $2.15 \mathrm{E}+00$ & $3.41 \mathrm{E}-02$ & $1.39 \mathrm{E}+00$ & $7.96 \mathrm{E}-01$ \\
Bladder & $8.38 \mathrm{E}-01$ & $1.41 \mathrm{E}+00$ & $2.12 \mathrm{E}-02$ & $9.22 \mathrm{E}-01$ & $5.29 \mathrm{E}-01$ \\
Lungs & $3.27 \mathrm{E}-01$ & $5.51 \mathrm{E}-01$ & $1.23 \mathrm{E}-02$ & $3.49 \mathrm{E}-01$ & $2.04 \mathrm{E}-01$ \\
Bone & $4.77 \mathrm{E}-01$ & $8.04 \mathrm{E}-01$ & $2.96 \mathrm{E}-02$ & $4.74 \mathrm{E}-01$ & $2.89 \mathrm{E}-01$ \\
Liver & $1.80 \mathrm{E}-01$ & $3.03 \mathrm{E}-01$ & $6.76 \mathrm{E}-03$ & $1.87 \mathrm{E}-01$ & $1.13 \mathrm{E}-01$ \\
Thyroid & $1.87 \mathrm{E}-01$ & $3.16 \mathrm{E}-01$ & $7.01 \mathrm{E}-03$ & $1.96 \mathrm{E}-01$ & $1.15 \mathrm{E}-01$ \\
Esophagus & $7.81 \mathrm{E}-02$ & $1.32 \mathrm{E}-01$ & $1.89 \mathrm{E}-03$ & $8.96 \mathrm{E}-02$ & $5.17 \mathrm{E}-02$ \\
Skin & $2.87 \mathrm{E}-02$ & $4.84 \mathrm{E}-02$ & $5.51 \mathrm{E}-03$ & $3.02 \mathrm{E}-02$ & $1.80 \mathrm{E}-02$ \\
Other & $5.16 \mathrm{E}-01$ & $1.95 \mathrm{E}-01$ & $3.70 \mathrm{E}-03$ & $1.25 \mathrm{E}-01$ & $7.06 \mathrm{E}-02$ \\
Breasts & $1.37 \mathrm{E}+00$ & $6.92 \mathrm{E}-01$ & $5.21 \mathrm{E}-02$ & $3.93 \mathrm{E}-01$ & $2.37 \mathrm{E}-01$ \\
\hline Total & $7.29 \mathrm{E}+00$ & $1.00 \mathrm{E}+01$ & $2.55 \mathrm{E}-01$ & $6.30 \mathrm{E}+00$ & $3.68 \mathrm{E}+00$ \\
\hline
\end{tabular}

Table I.12 Effective Dose Contribution by Organ from Reference Female Patient to the Adipose Male Healthcare Provider for $37 \mathrm{GBq} / \mathrm{m}^{2}$ Surface Contamination $(\mathrm{mSv} / \mathrm{hr})$

\begin{tabular}{|c|ccccc|}
\hline Organ & Co-60 & Ir-192 & Am-241 & Cs-137 & I-131 \\
\hline \hline Gonads & $2.57 \mathrm{E}+00$ & $8.35 \mathrm{E}-01$ & $1.73 \mathrm{E}-02$ & $5.71 \mathrm{E}-01$ & $3.27 \mathrm{E}-01$ \\
Stomach & $4.49 \mathrm{E}+00$ & $1.88 \mathrm{E}+00$ & $4.44 \mathrm{E}-02$ & $1.14 \mathrm{E}+00$ & $6.97 \mathrm{E}-01$ \\
Colon Wall & $4.92 \mathrm{E}+00$ & $1.73 \mathrm{E}+00$ & $2.77 \mathrm{E}-02$ & $1.14 \mathrm{E}+00$ & $6.44 \mathrm{E}-01$ \\
Bladder & $3.08 \mathrm{E}+00$ & $1.04 \mathrm{E}+00$ & $1.59 \mathrm{E}-02$ & $7.10 \mathrm{E}-01$ & $3.95 \mathrm{E}-01$ \\
Lungs & $1.20 \mathrm{E}+00$ & $4.75 \mathrm{E}-01$ & $1.04 \mathrm{E}-02$ & $2.99 \mathrm{E}-01$ & $1.76 \mathrm{E}-01$ \\
Bone & $1.66 \mathrm{E}+00$ & $6.70 \mathrm{E}-01$ & $2.46 \mathrm{E}-02$ & $3.98 \mathrm{E}-01$ & $2.41 \mathrm{E}-01$ \\
Liver & $6.09 \mathrm{E}-01$ & $2.44 \mathrm{E}-01$ & $5.38 \mathrm{E}-03$ & $1.51 \mathrm{E}-01$ & $9.00 \mathrm{E}-02$ \\
Thyroid & $6.66 \mathrm{E}-01$ & $2.50 \mathrm{E}-01$ & $5.75 \mathrm{E}-03$ & $1.64 \mathrm{E}-01$ & $9.41 \mathrm{E}-02$ \\
Esophagus & $3.23 \mathrm{E}-01$ & $1.13 \mathrm{E}-01$ & $1.60 \mathrm{E}-03$ & $7.77 \mathrm{E}-02$ & $4.35 \mathrm{E}-02$ \\
Skin & $9.52 \mathrm{E}-02$ & $3.92 \mathrm{E}-02$ & $4.24 \mathrm{E}-03$ & $2.46 \mathrm{E}-02$ & $1.46 \mathrm{E}-02$ \\
Other & $4.42 \mathrm{E}-01$ & $1.65 \mathrm{E}-01$ & $2.90 \mathrm{E}-03$ & $1.09 \mathrm{E}-01$ & $6.11 \mathrm{E}-02$ \\
Breasts & $1.26 \mathrm{E}+00$ & $6.02 \mathrm{E}-01$ & $3.94 \mathrm{E}-02$ & $3.68 \mathrm{E}-01$ & $2.11 \mathrm{E}-01$ \\
\hline Total & $2.13 \mathrm{E}+01$ & $8.05 \mathrm{E}+00$ & $1.99 \mathrm{E}-01$ & $5.16 \mathrm{E}+00$ & $2.99 \mathrm{E}+00$ \\
\hline
\end{tabular}


Table I.13 Effective Dose Contribution by Organ from Adipose Male Patient to the Adipose Male Healthcare Provider for $37 \mathrm{GBq} / \mathrm{m}^{2}$ Surface Contamination $(\mathrm{mSv} / \mathrm{hr})$

\begin{tabular}{|c|ccccc|}
\hline Organ & Co-60 & Ir-192 & Am-241 & Cs-137 & I-131 \\
\hline \hline Gonads & $3.45 \mathrm{E}+00$ & $1.27 \mathrm{E}+00$ & $2.78 \mathrm{E}-02$ & $8.42 \mathrm{E}-01$ & $4.74 \mathrm{E}-01$ \\
Stomach & $5.68 \mathrm{E}+00$ & $2.32 \mathrm{E}+00$ & $5.25 \mathrm{E}-02$ & $1.42 \mathrm{E}+00$ & $8.52 \mathrm{E}-01$ \\
Colon Wall & $6.26 \mathrm{E}+00$ & $2.18 \mathrm{E}+00$ & $3.37 \mathrm{E}-02$ & $1.43 \mathrm{E}+00$ & $8.24 \mathrm{E}-01$ \\
Bladder & $4.11 \mathrm{E}+00$ & $1.41 \mathrm{E}+00$ & $2.04 \mathrm{E}-02$ & $9.61 \mathrm{E}-01$ & $5.30 \mathrm{E}-01$ \\
Lungs & $1.55 \mathrm{E}+00$ & $5.93 \mathrm{E}-01$ & $1.27 \mathrm{E}-02$ & $3.77 \mathrm{E}-01$ & $2.19 \mathrm{E}-01$ \\
Bone & $2.23 \mathrm{E}+00$ & $8.86 \mathrm{E}-01$ & $3.22 \mathrm{E}-02$ & $5.31 \mathrm{E}-01$ & $3.19 \mathrm{E}-01$ \\
Liver & $7.45 \mathrm{E}-01$ & $2.91 \mathrm{E}-01$ & $6.25 \mathrm{E}-03$ & $1.81 \mathrm{E}-01$ & $1.08 \mathrm{E}-01$ \\
Thyroid & $8.88 \mathrm{E}-01$ & $3.34 \mathrm{E}-01$ & $8.49 \mathrm{E}-03$ & $2.10 \mathrm{E}-01$ & $1.26 \mathrm{E}-01$ \\
Esophagus & $4.52 \mathrm{E}-01$ & $1.44 \mathrm{E}-01$ & $1.99 \mathrm{E}-03$ & $9.70 \mathrm{E}-02$ & $5.55 \mathrm{E}-02$ \\
Skin & $1.20 \mathrm{E}-01$ & $4.69 \mathrm{E}-02$ & $4.53 \mathrm{E}-03$ & $3.01 \mathrm{E}-02$ & $1.75 \mathrm{E}-02$ \\
Other & $5.65 \mathrm{E}-01$ & $1.99 \mathrm{E}-01$ & $3.50 \mathrm{E}-03$ & $1.32 \mathrm{E}-01$ & $7.70 \mathrm{E}-02$ \\
Breasts & $1.76 \mathrm{E}+00$ & $7.13 \mathrm{E}-01$ & $4.72 \mathrm{E}-02$ & $4.50 \mathrm{E}-01$ & $2.52 \mathrm{E}-01$ \\
\hline Total & $2.78 \mathrm{E}+01$ & $1.04 \mathrm{E}+01$ & $2.51 \mathrm{E}-01$ & $6.66 \mathrm{E}+00$ & $3.85 \mathrm{E}+00$ \\
\hline
\end{tabular}

Table I.14 Effective Dose Contribution by Organ from Adipose Female Patient to the Adipose Male Healthcare Provider for $37 \mathrm{GBq} / \mathrm{m}^{2}$ Surface Contamination $(\mathrm{mSv} / \mathrm{hr})$

\begin{tabular}{|c|ccccc|}
\hline Organ & Co-60 & Ir-192 & Am-241 & Cs-137 & I-131 \\
\hline \hline Gonads & $2.95 \mathrm{E}+00$ & $1.01 \mathrm{E}+00$ & $2.24 \mathrm{E}-02$ & $6.73 \mathrm{E}-01$ & $3.81 \mathrm{E}-01$ \\
Stomach & $5.58 \mathrm{E}+00$ & $2.31 \mathrm{E}+00$ & $5.50 \mathrm{E}-02$ & $1.41 \mathrm{E}+00$ & $8.54 \mathrm{E}-01$ \\
Colon Wall & $5.95 \mathrm{E}+00$ & $2.12 \mathrm{E}+00$ & $3.21 \mathrm{E}-02$ & $1.38 \mathrm{E}+00$ & $7.89 \mathrm{E}-01$ \\
Bladder & $3.62 \mathrm{E}+00$ & $1.26 \mathrm{E}+00$ & $1.82 \mathrm{E}-02$ & $8.25 \mathrm{E}-01$ & $4.70 \mathrm{E}-01$ \\
Lungs & $1.49 \mathrm{E}+00$ & $5.83 \mathrm{E}-01$ & $1.29 \mathrm{E}-02$ & $3.68 \mathrm{E}-01$ & $2.16 \mathrm{E}-01$ \\
Bone & $2.00 \mathrm{E}+00$ & $8.12 \mathrm{E}-01$ & $3.03 \mathrm{E}-02$ & $4.81 \mathrm{E}-01$ & $2.91 \mathrm{E}-01$ \\
Liver & $7.42 \mathrm{E}-01$ & $2.97 \mathrm{E}-01$ & $6.55 \mathrm{E}-03$ & $1.83 \mathrm{E}-01$ & $1.10 \mathrm{E}-01$ \\
Thyroid & $8.39 \mathrm{E}-01$ & $3.33 \mathrm{E}-01$ & $7.76 \mathrm{E}-03$ & $2.15 \mathrm{E}-01$ & $1.18 \mathrm{E}-01$ \\
Esophagus & $4.18 \mathrm{E}-01$ & $1.45 \mathrm{E}-01$ & $2.40 \mathrm{E}-03$ & $9.56 \mathrm{E}-02$ & $5.58 \mathrm{E}-02$ \\
Skin & $1.14 \mathrm{E}-01$ & $4.66 \mathrm{E}-02$ & $4.96 \mathrm{E}-03$ & $2.93 \mathrm{E}-02$ & $1.74 \mathrm{E}-02$ \\
Other & $5.46 \mathrm{E}-01$ & $1.95 \mathrm{E}-01$ & $3.25 \mathrm{E}-03$ & $1.29 \mathrm{E}-01$ & $7.11 \mathrm{E}-02$ \\
Breasts & $1.61 \mathrm{E}+00$ & $8.19 \mathrm{E}-01$ & $5.07 \mathrm{E}-02$ & $4.25 \mathrm{E}-01$ & $2.76 \mathrm{E}-01$ \\
\hline Total & $2.59 \mathrm{E}+01$ & $9.93 \mathrm{E}+00$ & $2.46 \mathrm{E}-01$ & $6.22 \mathrm{E}+00$ & $3.65 \mathrm{E}+00$ \\
\hline
\end{tabular}


Table I.15 Effective Dose Contribution by Organ from Postmenopausal Adipose Female Patient to the Adipose Male Healthcare Provider for $37 \mathrm{GBq} / \mathrm{m}^{2}$ Surface Contamination $(\mathrm{mSv} / \mathrm{hr})$

\begin{tabular}{|c|ccccc|}
\hline Organ & Co-60 & Ir-192 & Am-241 & Cs-137 & I-131 \\
\hline \hline Gonads & $2.89 \mathrm{E}+00$ & $1.02 \mathrm{E}+00$ & $2.22 \mathrm{E}-02$ & $6.94 \mathrm{E}-01$ & $3.83 \mathrm{E}-01$ \\
Stomach & $5.40 \mathrm{E}+00$ & $2.21 \mathrm{E}+00$ & $5.35 \mathrm{E}-02$ & $1.35 \mathrm{E}+00$ & $8.18 \mathrm{E}-01$ \\
Colon Wall & $5.90 \mathrm{E}+00$ & $2.03 \mathrm{E}+00$ & $3.22 \mathrm{E}-02$ & $1.35 \mathrm{E}+00$ & $7.76 \mathrm{E}-01$ \\
Bladder & $3.73 \mathrm{E}+00$ & $1.26 \mathrm{E}+00$ & $1.95 \mathrm{E}-02$ & $8.51 \mathrm{E}-01$ & $4.76 \mathrm{E}-01$ \\
Lungs & $1.45 \mathrm{E}+00$ & $5.62 \mathrm{E}-01$ & $1.22 \mathrm{E}-02$ & $3.54 \mathrm{E}-01$ & $2.08 \mathrm{E}-01$ \\
Bone & $2.01 \mathrm{E}+00$ & $8.08 \mathrm{E}-01$ & $2.97 \mathrm{E}-02$ & $4.79 \mathrm{E}-01$ & $2.89 \mathrm{E}-01$ \\
Liver & $7.09 \mathrm{E}-01$ & $2.83 \mathrm{E}-01$ & $6.15 \mathrm{E}-03$ & $1.75 \mathrm{E}-01$ & $1.04 \mathrm{E}-01$ \\
Thyroid & $8.39 \mathrm{E}-01$ & $3.20 \mathrm{E}-01$ & $7.73 \mathrm{E}-03$ & $2.07 \mathrm{E}-01$ & $1.27 \mathrm{E}-01$ \\
Esophagus & $3.97 \mathrm{E}-01$ & $1.36 \mathrm{E}-01$ & $2.00 \mathrm{E}-03$ & $9.32 \mathrm{E}-02$ & $5.25 \mathrm{E}-02$ \\
Skin & $1.12 \mathrm{E}-01$ & $4.45 \mathrm{E}-02$ & $4.50 \mathrm{E}-03$ & $2.84 \mathrm{E}-02$ & $1.67 \mathrm{E}-02$ \\
Other & $5.30 \mathrm{E}-01$ & $1.94 \mathrm{E}-01$ & $3.24 \mathrm{E}-03$ & $1.31 \mathrm{E}-01$ & $7.53 \mathrm{E}-02$ \\
Breasts & $1.51 \mathrm{E}+00$ & $7.23 \mathrm{E}-01$ & $4.75 \mathrm{E}-02$ & $3.94 \mathrm{E}-01$ & $2.50 \mathrm{E}-01$ \\
\hline Total & $2.55 \mathrm{E}+01$ & $9.58 \mathrm{E}+00$ & $2.40 \mathrm{E}-01$ & $6.10 \mathrm{E}+00$ & $3.58 \mathrm{E}+00$ \\
\hline
\end{tabular}

Table I.16 Effective Dose Contribution by Organ from Reference Male Patient to the Adipose Female Healthcare Provider for $37 \mathrm{GBq} / \mathrm{m}^{2}$ Surface Contamination $(\mathrm{mSv} / \mathrm{hr})$

\begin{tabular}{|c|ccccc|}
\hline Organ & Co-60 & Ir-192 & Am-241 & Cs-137 & I-131 \\
\hline \hline Gonads & $2.53 \mathrm{E}+00$ & $9.54 \mathrm{E}-01$ & $1.34 \mathrm{E}-02$ & $5.95 \mathrm{E}-01$ & $3.73 \mathrm{E}-01$ \\
Stomach & $5.49 \mathrm{E}+00$ & $2.38 \mathrm{E}+00$ & $6.33 \mathrm{E}-02$ & $1.41 \mathrm{E}+00$ & $8.63 \mathrm{E}-01$ \\
Colon Wall & $5.59 \mathrm{E}+00$ & $2.09 \mathrm{E}+00$ & $3.88 \mathrm{E}-02$ & $1.33 \mathrm{E}+00$ & $7.75 \mathrm{E}-01$ \\
Bladder & $4.30 \mathrm{E}+00$ & $1.61 \mathrm{E}+00$ & $2.89 \mathrm{E}-02$ & $1.03 \mathrm{E}+00$ & $6.00 \mathrm{E}-01$ \\
Lungs & $1.60 \mathrm{E}+00$ & $6.33 \mathrm{E}-01$ & $1.52 \mathrm{E}-02$ & $3.97 \mathrm{E}-01$ & $2.35 \mathrm{E}-01$ \\
Bone & $2.17 \mathrm{E}+00$ & $9.01 \mathrm{E}-01$ & $3.71 \mathrm{E}-02$ & $5.28 \mathrm{E}-01$ & $3.22 \mathrm{E}-01$ \\
Liver & $8.85 \mathrm{E}-01$ & $3.74 \mathrm{E}-01$ & $9.31 \mathrm{E}-03$ & $2.27 \mathrm{E}-01$ & $1.38 \mathrm{E}-01$ \\
Thyroid & $7.51 \mathrm{E}-01$ & $3.21 \mathrm{E}-01$ & $8.89 \mathrm{E}-03$ & $1.94 \mathrm{E}-01$ & $1.19 \mathrm{E}-01$ \\
Esophagus & $5.59 \mathrm{E}-01$ & $1.87 \mathrm{E}-01$ & $3.11 \mathrm{E}-03$ & $1.30 \mathrm{E}-01$ & $6.78 \mathrm{E}-02$ \\
Skin & $1.91 \mathrm{E}-01$ & $8.17 \mathrm{E}-02$ & $8.66 \mathrm{E}-03$ & $5.02 \mathrm{E}-02$ & $3.03 \mathrm{E}-02$ \\
Other & $6.74 \mathrm{E}-01$ & $2.51 \mathrm{E}-01$ & $4.87 \mathrm{E}-03$ & $1.65 \mathrm{E}-01$ & $9.39 \mathrm{E}-02$ \\
Breasts & $3.09 \mathrm{E}+00$ & $1.42 \mathrm{E}+00$ & $7.92 \mathrm{E}-02$ & $8.28 \mathrm{E}-01$ & $5.22 \mathrm{E}-01$ \\
\hline Total & $2.78 \mathrm{E}+01$ & $1.12 \mathrm{E}+01$ & $3.11 \mathrm{E}-01$ & $6.89 \mathrm{E}+00$ & $4.14 \mathrm{E}+00$ \\
\hline
\end{tabular}


Table I.17 Effective Dose Contribution by Organ from Reference Female Patient to the Adipose Female Healthcare Provider for $37 \mathrm{GBq} / \mathrm{m}^{2}$ Surface Contamination $(\mathrm{mSv} / \mathrm{hr})$

\begin{tabular}{|c|ccccc|}
\hline Organ & Co-60 & Ir-192 & Am-241 & Cs-137 & I-131 \\
\hline \hline Gonads & $2.02 \mathrm{E}+00$ & $7.32 \mathrm{E}-01$ & $9.25 \mathrm{E}-03$ & $4.68 \mathrm{E}-01$ & $2.56 \mathrm{E}-01$ \\
Stomach & $4.70 \mathrm{E}+00$ & $2.05 \mathrm{E}+00$ & $5.66 \mathrm{E}-02$ & $1.22 \mathrm{E}+00$ & $7.51 \mathrm{E}-01$ \\
Colon Wall & $4.53 \mathrm{E}+00$ & $1.69 \mathrm{E}+00$ & $3.10 \mathrm{E}-02$ & $1.09 \mathrm{E}+00$ & $6.34 \mathrm{E}-01$ \\
Bladder & $3.29 \mathrm{E}+00$ & $1.19 \mathrm{E}+00$ & $2.08 \mathrm{E}-02$ & $7.68 \mathrm{E}-01$ & $4.43 \mathrm{E}-01$ \\
Lungs & $1.36 \mathrm{E}+00$ & $5.45 \mathrm{E}-01$ & $1.25 \mathrm{E}-02$ & $3.37 \mathrm{E}-01$ & $2.00 \mathrm{E}-01$ \\
Bone & $1.81 \mathrm{E}+00$ & $7.47 \mathrm{E}-01$ & $3.05 \mathrm{E}-02$ & $4.40 \mathrm{E}-01$ & $2.68 \mathrm{E}-01$ \\
Liver & $7.08 \mathrm{E}-01$ & $2.98 \mathrm{E}-01$ & $7.37 \mathrm{E}-03$ & $1.80 \mathrm{E}-01$ & $1.09 \mathrm{E}-01$ \\
Thyroid & $7.01 \mathrm{E}-01$ & $2.67 \mathrm{E}-01$ & $8.38 \mathrm{E}-03$ & $1.69 \mathrm{E}-01$ & $1.01 \mathrm{E}-01$ \\
Esophagus & $4.52 \mathrm{E}-01$ & $1.71 \mathrm{E}-01$ & $2.53 \mathrm{E}-03$ & $1.12 \mathrm{E}-01$ & $6.43 \mathrm{E}-02$ \\
Skin & $1.57 \mathrm{E}-01$ & $6.63 \mathrm{E}-02$ & $6.69 \mathrm{E}-03$ & $4.11 \mathrm{E}-02$ & $2.46 \mathrm{E}-02$ \\
Other & $5.52 \mathrm{E}-01$ & $2.02 \mathrm{E}-01$ & $3.90 \mathrm{E}-03$ & $1.31 \mathrm{E}-01$ & $7.78 \mathrm{E}-02$ \\
Breasts & $2.63 \mathrm{E}+00$ & $1.19 \mathrm{E}+00$ & $6.52 \mathrm{E}-02$ & $7.00 \mathrm{E}-01$ & $4.38 \mathrm{E}-01$ \\
\hline Total & $2.29 \mathrm{E}+01$ & $9.15 \mathrm{E}+00$ & $2.55 \mathrm{E}-01$ & $5.65 \mathrm{E}+00$ & $3.37 \mathrm{E}+00$ \\
\hline
\end{tabular}

Table I.18 Effective Dose Contribution by Organ from Adipose Male Patient to the Adipose Female Healthcare Provider for $37 \mathrm{GBq} / \mathrm{m}^{2}$ Surface Contamination $(\mathrm{mSv} / \mathrm{hr})$

\begin{tabular}{|c|ccccc|}
\hline Organ & Co-60 & Ir-192 & Am-241 & Cs-137 & I-131 \\
\hline \hline Gonads & $2.93 \mathrm{E}+00$ & $1.00 \mathrm{E}+00$ & $1.27 \mathrm{E}-02$ & $6.67 \mathrm{E}-01$ & $3.78 \mathrm{E}-01$ \\
Stomach & $5.71 \mathrm{E}+00$ & $2.44 \mathrm{E}+00$ & $6.28 \mathrm{E}-02$ & $1.45 \mathrm{E}+00$ & $8.83 \mathrm{E}-01$ \\
Colon Wall & $5.81 \mathrm{E}+00$ & $2.14 \mathrm{E}+00$ & $3.81 \mathrm{E}-02$ & $1.37 \mathrm{E}+00$ & $7.93 \mathrm{E}-01$ \\
Bladder & $4.53 \mathrm{E}+00$ & $1.56 \mathrm{E}+00$ & $2.62 \mathrm{E}-02$ & $1.04 \mathrm{E}+00$ & $5.85 \mathrm{E}-01$ \\
Lungs & $1.73 \mathrm{E}+00$ & $6.70 \mathrm{E}-01$ & $1.52 \mathrm{E}-02$ & $4.20 \mathrm{E}-01$ & $2.49 \mathrm{E}-01$ \\
Bone & $2.42 \mathrm{E}+00$ & $9.72 \mathrm{E}-01$ & $3.91 \mathrm{E}-02$ & $5.78 \mathrm{E}-01$ & $3.49 \mathrm{E}-01$ \\
Liver & $8.47 \mathrm{E}-01$ & $3.43 \mathrm{E}-01$ & $8.08 \mathrm{E}-03$ & $2.12 \mathrm{E}-01$ & $1.27 \mathrm{E}-01$ \\
Thyroid & $9.12 \mathrm{E}-01$ & $3.44 \mathrm{E}-01$ & $9.86 \mathrm{E}-03$ & $2.27 \mathrm{E}-01$ & $1.35 \mathrm{E}-01$ \\
Esophagus & $6.13 \mathrm{E}-01$ & $2.04 \mathrm{E}-01$ & $2.94 \mathrm{E}-03$ & $1.36 \mathrm{E}-01$ & $7.47 \mathrm{E}-02$ \\
Skin & $1.99 \mathrm{E}-01$ & $8.00 \mathrm{E}-02$ & $7.35 \mathrm{E}-03$ & $5.03 \mathrm{E}-02$ & $2.98 \mathrm{E}-02$ \\
Other & $6.76 \mathrm{E}-01$ & $2.52 \mathrm{E}-01$ & $4.83 \mathrm{E}-03$ & $1.67 \mathrm{E}-01$ & $9.46 \mathrm{E}-02$ \\
Breasts & $3.26 \mathrm{E}+00$ & $1.42 \mathrm{E}+00$ & $7.31 \mathrm{E}-02$ & $8.52 \mathrm{E}-01$ & $5.22 \mathrm{E}-01$ \\
\hline Total & $2.96 \mathrm{E}+01$ & $1.14 \mathrm{E}+01$ & $3.00 \mathrm{E}-01$ & $7.17 \mathrm{E}+00$ & $4.22 \mathrm{E}+00$ \\
\hline
\end{tabular}


Table I.19 Effective Dose Contribution by Organ from Adipose Female Patient to the Adipose Female Healthcare Provider for $37 \mathrm{GBq} / \mathrm{m}^{2}$ Surface Contamination $(\mathrm{mSv} / \mathrm{hr})$

\begin{tabular}{|c|ccccc|}
\hline Organ & Co-60 & Ir-192 & Am-241 & Cs-137 & I-131 \\
\hline \hline Gonads & $5.37 \mathrm{E}+00$ & $1.49 \mathrm{E}+00$ & $2.86 \mathrm{E}-02$ & $1.14 \mathrm{E}+00$ & $6.21 \mathrm{E}-01$ \\
Stomach & $5.08 \mathrm{E}+00$ & $2.17 \mathrm{E}+00$ & $5.47 \mathrm{E}-02$ & $1.30 \mathrm{E}+00$ & $7.94 \mathrm{E}-01$ \\
Colon Wall & $5.18 \mathrm{E}+00$ & $1.83 \mathrm{E}+00$ & $2.93 \mathrm{E}-02$ & $1.19 \mathrm{E}+00$ & $6.80 \mathrm{E}-01$ \\
Bladder & $3.69 \mathrm{E}+00$ & $1.23 \mathrm{E}+00$ & $1.97 \mathrm{E}-02$ & $8.48 \mathrm{E}-01$ & $4.81 \mathrm{E}-01$ \\
Lungs & $1.55 \mathrm{E}+00$ & $6.04 \mathrm{E}-01$ & $1.30 \mathrm{E}-02$ & $3.77 \mathrm{E}-01$ & $2.21 \mathrm{E}-01$ \\
Bone & $2.12 \mathrm{E}+00$ & $8.68 \mathrm{E}-01$ & $3.24 \mathrm{E}-02$ & $5.11 \mathrm{E}-01$ & $3.09 \mathrm{E}-01$ \\
Liver & $7.72 \mathrm{E}-01$ & $3.11 \mathrm{E}-01$ & $7.07 \mathrm{E}-03$ & $1.92 \mathrm{E}-01$ & $1.16 \mathrm{E}-01$ \\
Thyroid & $1.14 \mathrm{E}+00$ & $4.58 \mathrm{E}-01$ & $1.22 \mathrm{E}-02$ & $2.92 \mathrm{E}-01$ & $1.72 \mathrm{E}-01$ \\
Esophagus & $5.54 \mathrm{E}-01$ & $1.80 \mathrm{E}-01$ & $2.86 \mathrm{E}-03$ & $1.29 \mathrm{E}-01$ & $7.09 \mathrm{E}-02$ \\
Skin & $1.68 \mathrm{E}-01$ & $6.96 \mathrm{E}-02$ & $6.66 \mathrm{E}-03$ & $4.32 \mathrm{E}-02$ & $2.57 \mathrm{E}-02$ \\
Other & $6.48 \mathrm{E}-01$ & $2.30 \mathrm{E}-01$ & $4.41 \mathrm{E}-03$ & $1.54 \mathrm{E}-01$ & $8.93 \mathrm{E}-02$ \\
Breasts & $2.83 \mathrm{E}+00$ & $1.27 \mathrm{E}+00$ & $6.79 \mathrm{E}-02$ & $7.48 \mathrm{E}-01$ & $4.64 \mathrm{E}-01$ \\
\hline Total & $2.91 \mathrm{E}+01$ & $1.07 \mathrm{E}+01$ & $2.79 \mathrm{E}-01$ & $6.93 \mathrm{E}+00$ & $4.04 \mathrm{E}+00$ \\
\hline
\end{tabular}

Table I.20 Effective Dose Contribution by Organ from Reference Male Patient to the Adipose Female Healthcare Provider for $37 \mathrm{GBq} / \mathrm{m}^{2}$ Surface Contamination $(\mathrm{mSv} / \mathrm{hr}$ )

\begin{tabular}{|c|ccccc|}
\hline Organ & Co-60 & Ir-192 & Am-241 & Cs-137 & I-131 \\
\hline \hline Gonads & $2.60 \mathrm{E}+00$ & $8.65 \mathrm{E}-01$ & $1.21 \mathrm{E}-02$ & $5.84 \mathrm{E}-01$ & $3.21 \mathrm{E}-01$ \\
Stomach & $5.36 \mathrm{E}+00$ & $2.35 \mathrm{E}+00$ & $6.29 \mathrm{E}-02$ & $1.39 \mathrm{E}+00$ & $8.59 \mathrm{E}-01$ \\
Colon Wall & $5.38 \mathrm{E}+00$ & $1.99 \mathrm{E}+00$ & $3.61 \mathrm{E}-02$ & $1.29 \mathrm{E}+00$ & $7.50 \mathrm{E}-01$ \\
Bladder & $4.04 \mathrm{E}+00$ & $1.43 \mathrm{E}+00$ & $2.43 \mathrm{E}-02$ & $9.38 \mathrm{E}-01$ & $5.43 \mathrm{E}-01$ \\
Lungs & $1.61 \mathrm{E}+00$ & $6.29 \mathrm{E}-01$ & $1.41 \mathrm{E}-02$ & $3.96 \mathrm{E}-01$ & $2.32 \mathrm{E}-01$ \\
Bone & $2.19 \mathrm{E}+00$ & $8.91 \mathrm{E}-01$ & $3.63 \mathrm{E}-02$ & $5.30 \mathrm{E}-01$ & $3.20 \mathrm{E}-01$ \\
Liver & $8.22 \mathrm{E}-01$ & $3.39 \mathrm{E}-01$ & $8.28 \mathrm{E}-03$ & $2.06 \mathrm{E}-01$ & $1.25 \mathrm{E}-01$ \\
Thyroid & $7.96 \mathrm{E}-01$ & $3.25 \mathrm{E}-01$ & $1.05 \mathrm{E}-02$ & $2.01 \mathrm{E}-01$ & $1.28 \mathrm{E}-01$ \\
Esophagus & $5.72 \mathrm{E}-01$ & $1.94 \mathrm{E}-01$ & $3.02 \mathrm{E}-03$ & $1.29 \mathrm{E}-01$ & $7.78 \mathrm{E}-02$ \\
Skin & $1.85 \mathrm{E}-01$ & $7.61 \mathrm{E}-02$ & $7.30 \mathrm{E}-03$ & $4.75 \mathrm{E}-02$ & $2.83 \mathrm{E}-02$ \\
Other & $6.32 \mathrm{E}-01$ & $2.43 \mathrm{E}-01$ & $4.63 \mathrm{E}-03$ & $1.60 \mathrm{E}-01$ & $8.93 \mathrm{E}-02$ \\
Breasts & $3.05 \mathrm{E}+00$ & $1.36 \mathrm{E}+00$ & $7.18 \mathrm{E}-02$ & $8.01 \mathrm{E}-01$ & $4.99 \mathrm{E}-01$ \\
\hline Total & $2.72 \mathrm{E}+01$ & $1.07 \mathrm{E}+01$ & $2.91 \mathrm{E}-01$ & $6.68 \mathrm{E}+00$ & $3.97 \mathrm{E}+00$ \\
\hline
\end{tabular}


Table I.21 Effective Dose Contribution by Organ from Reference Female Patient to the Postmenopausal Adipose Female Healthcare Provider for $37 \mathrm{GBq} / \mathrm{m}^{2}$ Surface Contamination $(\mathrm{mSv} / \mathrm{hr})$

\begin{tabular}{|c|ccccc|}
\hline Organ & Co-60 & Ir-192 & Am-241 & Cs-137 & I-131 \\
\hline \hline Gonads & $5.01 \mathrm{E}+00$ & $1.83 \mathrm{E}+00$ & $2.70 \mathrm{E}-02$ & $1.21 \mathrm{E}+00$ & $6.64 \mathrm{E}-01$ \\
Stomach & $5.07 \mathrm{E}+00$ & $2.15 \mathrm{E}+00$ & $5.36 \mathrm{E}-02$ & $1.29 \mathrm{E}+00$ & $7.93 \mathrm{E}-01$ \\
Colon Wall & $5.12 \mathrm{E}+00$ & $1.91 \mathrm{E}+00$ & $3.13 \mathrm{E}-02$ & $1.22 \mathrm{E}+00$ & $7.09 \mathrm{E}-01$ \\
Bladder & $4.04 \mathrm{E}+00$ & $1.44 \mathrm{E}+00$ & $2.41 \mathrm{E}-02$ & $9.41 \mathrm{E}-01$ & $5.40 \mathrm{E}-01$ \\
Lungs & $1.55 \mathrm{E}+00$ & $6.12 \mathrm{E}-01$ & $1.36 \mathrm{E}-02$ & $3.80 \mathrm{E}-01$ & $2.25 \mathrm{E}-01$ \\
Bone & $2.10 \mathrm{E}+00$ & $8.73 \mathrm{E}-01$ & $3.26 \mathrm{E}-02$ & $5.10 \mathrm{E}-01$ & $3.12 \mathrm{E}-01$ \\
Liver & $8.28 \mathrm{E}-01$ & $3.43 \mathrm{E}-01$ & $7.90 \mathrm{E}-03$ & $2.09 \mathrm{E}-01$ & $1.27 \mathrm{E}-01$ \\
Thyroid & $1.07 \mathrm{E}+00$ & $4.24 \mathrm{E}-01$ & $1.06 \mathrm{E}-02$ & $2.71 \mathrm{E}-01$ & $1.62 \mathrm{E}-01$ \\
Esophagus & $4.91 \mathrm{E}-01$ & $1.77 \mathrm{E}-01$ & $2.74 \mathrm{E}-03$ & $1.19 \mathrm{E}-01$ & $6.66 \mathrm{E}-02$ \\
Skin & $1.75 \mathrm{E}-01$ & $7.44 \mathrm{E}-02$ & $7.98 \mathrm{E}-03$ & $4.58 \mathrm{E}-02$ & $2.75 \mathrm{E}-02$ \\
Other & $6.33 \mathrm{E}-01$ & $2.34 \mathrm{E}-01$ & $4.20 \mathrm{E}-03$ & $1.48 \mathrm{E}-01$ & $8.48 \mathrm{E}-02$ \\
Breasts & $2.89 \mathrm{E}+00$ & $1.32 \mathrm{E}+00$ & $7.52 \mathrm{E}-02$ & $7.71 \mathrm{E}-01$ & $4.86 \mathrm{E}-01$ \\
\hline Total & $2.90 \mathrm{E}+01$ & $1.14 \mathrm{E}+01$ & $2.91 \mathrm{E}-01$ & $7.11 \mathrm{E}+00$ & $4.19 \mathrm{E}+00$ \\
\hline
\end{tabular}

Table I.22 Effective Dose Contribution by Organ from Adipose Male Patient to the Postmenopausal Adipose Female Healthcare Provider for $37 \mathrm{GBq} / \mathrm{m}^{2}$ Surface Contamination $(\mathrm{mSv} / \mathrm{hr})$

\begin{tabular}{|c|ccccc|}
\hline Organ & Co-60 & Ir-192 & Am-241 & Cs-137 & I-131 \\
\hline \hline Gonads & $4.22 \mathrm{E}+00$ & $1.34 \mathrm{E}+00$ & $2.00 \mathrm{E}-02$ & $9.28 \mathrm{E}-01$ & $5.78 \mathrm{E}-01$ \\
Stomach & $4.35 \mathrm{E}+00$ & $1.87 \mathrm{E}+00$ & $4.53 \mathrm{E}-02$ & $1.12 \mathrm{E}+00$ & $6.86 \mathrm{E}-01$ \\
Colon Wall & $4.27 \mathrm{E}+00$ & $1.52 \mathrm{E}+00$ & $2.46 \mathrm{E}-02$ & $9.93 \mathrm{E}-01$ & $5.70 \mathrm{E}-01$ \\
Bladder & $3.07 \mathrm{E}+00$ & $1.06 \mathrm{E}+00$ & $1.65 \mathrm{E}-02$ & $7.09 \mathrm{E}-01$ & $3.95 \mathrm{E}-01$ \\
Lungs & $1.32 \mathrm{E}+00$ & $5.17 \mathrm{E}-01$ & $1.13 \mathrm{E}-02$ & $3.27 \mathrm{E}-01$ & $1.91 \mathrm{E}-01$ \\
Bone & $1.76 \mathrm{E}+00$ & $7.23 \mathrm{E}-01$ & $2.69 \mathrm{E}-02$ & $4.25 \mathrm{E}-01$ & $2.59 \mathrm{E}-01$ \\
Liver & $6.66 \mathrm{E}-01$ & $2.76 \mathrm{E}-01$ & $6.25 \mathrm{E}-03$ & $1.68 \mathrm{E}-01$ & $1.01 \mathrm{E}-01$ \\
Thyroid & $9.89 \mathrm{E}-01$ & $3.66 \mathrm{E}-01$ & $1.02 \mathrm{E}-02$ & $2.39 \mathrm{E}-01$ & $1.38 \mathrm{E}-01$ \\
Esophagus & $4.48 \mathrm{E}-01$ & $1.71 \mathrm{E}-01$ & $2.31 \mathrm{E}-03$ & $1.09 \mathrm{E}-01$ & $6.14 \mathrm{E}-02$ \\
Skin & $1.44 \mathrm{E}-01$ & $6.02 \mathrm{E}-02$ & $6.17 \mathrm{E}-03$ & $3.74 \mathrm{E}-02$ & $2.24 \mathrm{E}-02$ \\
Other & $5.63 \mathrm{E}-01$ & $1.98 \mathrm{E}-01$ & $3.68 \mathrm{E}-03$ & $1.30 \mathrm{E}-01$ & $7.47 \mathrm{E}-02$ \\
Breasts & $2.45 \mathrm{E}+00$ & $1.11 \mathrm{E}+00$ & $6.16 \mathrm{E}-02$ & $6.52 \mathrm{E}-01$ & $4.08 \mathrm{E}-01$ \\
\hline Total & $2.42 \mathrm{E}+01$ & $9.21 \mathrm{E}+00$ & $2.35 \mathrm{E}-01$ & $5.83 \mathrm{E}+00$ & $3.49 \mathrm{E}+00$ \\
\hline
\end{tabular}


Table I.23 Effective Dose Contribution by Organ from Adipose Female Patient to the Postmenopausal Adipose Female Healthcare Provider for $37 \mathrm{GBq} / \mathrm{m}^{2}$ Surface Contamination $(\mathrm{mSv} / \mathrm{hr})$

\begin{tabular}{|c|ccccc|}
\hline Organ & Co-60 & Ir-192 & Am-241 & Cs-137 & I-131 \\
\hline \hline Gonads & $5.53 \mathrm{E}+00$ & $1.90 \mathrm{E}+00$ & $2.58 \mathrm{E}-02$ & $1.21 \mathrm{E}+00$ & $6.52 \mathrm{E}-01$ \\
Stomach & $5.35 \mathrm{E}+00$ & $2.25 \mathrm{E}+00$ & $5.36 \mathrm{E}-02$ & $1.36 \mathrm{E}+00$ & $8.33 \mathrm{E}-01$ \\
Colon Wall & $5.44 \mathrm{E}+00$ & $1.94 \mathrm{E}+00$ & $3.20 \mathrm{E}-02$ & $1.29 \mathrm{E}+00$ & $7.25 \mathrm{E}-01$ \\
Bladder & $4.12 \mathrm{E}+00$ & $1.40 \mathrm{E}+00$ & $2.17 \mathrm{E}-02$ & $9.53 \mathrm{E}-01$ & $5.29 \mathrm{E}-01$ \\
Lungs & $1.67 \mathrm{E}+00$ & $6.41 \mathrm{E}-01$ & $1.36 \mathrm{E}-02$ & $4.04 \mathrm{E}-01$ & $2.37 \mathrm{E}-01$ \\
Bone & $2.35 \mathrm{E}+00$ & $9.47 \mathrm{E}-01$ & $3.49 \mathrm{E}-02$ & $5.61 \mathrm{E}-01$ & $3.40 \mathrm{E}-01$ \\
Liver & $8.07 \mathrm{E}-01$ & $3.18 \mathrm{E}-01$ & $7.03 \mathrm{E}-03$ & $1.98 \mathrm{E}-01$ & $1.18 \mathrm{E}-01$ \\
Thyroid & $1.33 \mathrm{E}+00$ & $4.94 \mathrm{E}-01$ & $1.31 \mathrm{E}-02$ & $3.10 \mathrm{E}-01$ & $1.89 \mathrm{E}-01$ \\
Esophagus & $5.75 \mathrm{E}-01$ & $2.00 \mathrm{E}-01$ & $2.50 \mathrm{E}-03$ & $1.37 \mathrm{E}-01$ & $7.31 \mathrm{E}-02$ \\
Skin & $1.81 \mathrm{E}-01$ & $7.21 \mathrm{E}-02$ & $6.69 \mathrm{E}-03$ & $4.55 \mathrm{E}-02$ & $2.69 \mathrm{E}-02$ \\
Other & $6.45 \mathrm{E}-01$ & $2.42 \mathrm{E}-01$ & $4.14 \mathrm{E}-03$ & $1.53 \mathrm{E}-01$ & $8.90 \mathrm{E}-02$ \\
Breasts & $3.03 \mathrm{E}+00$ & $1.32 \mathrm{E}+00$ & $6.93 \mathrm{E}-02$ & $7.90 \mathrm{E}-01$ & $4.85 \mathrm{E}-01$ \\
\hline Total & $3.10 \mathrm{E}+01$ & $1.17 \mathrm{E}+01$ & $2.84 \mathrm{E}-01$ & $7.40 \mathrm{E}+00$ & $4.30 \mathrm{E}+00$ \\
\hline
\end{tabular}

Table I.24 Effective Dose Contribution by Organ from Postmenopausal Adipose Female Patient to the Postmenopausal Adipose Female Healthcare Provider for $37 \mathrm{GBq} / \mathrm{m}^{2}$ Surface

Contamination $(\mathrm{mSv} / \mathrm{hr})$

\begin{tabular}{|c|ccccc|}
\hline Organ & Co-60 & Ir-192 & Am-241 & Cs-137 & I-131 \\
\hline \hline Gonads & $5.06 \mathrm{E}+00$ & $1.76 \mathrm{E}+00$ & $2.37 \mathrm{E}-02$ & $1.11 \mathrm{E}+00$ & $6.52 \mathrm{E}-01$ \\
Stomach & $5.37 \mathrm{E}+00$ & $2.32 \mathrm{E}+00$ & $5.95 \mathrm{E}-02$ & $1.37 \mathrm{E}+00$ & $8.43 \mathrm{E}-01$ \\
Colon Wall & $5.13 \mathrm{E}+00$ & $1.88 \mathrm{E}+00$ & $3.14 \mathrm{E}-02$ & $1.22 \mathrm{E}+00$ & $7.11 \mathrm{E}-01$ \\
Bladder & $3.61 \mathrm{E}+00$ & $1.25 \mathrm{E}+00$ & $2.00 \mathrm{E}-02$ & $8.33 \mathrm{E}-01$ & $4.68 \mathrm{E}-01$ \\
Lungs & $1.59 \mathrm{E}+00$ & $6.29 \mathrm{E}-01$ & $1.38 \mathrm{E}-02$ & $3.91 \mathrm{E}-01$ & $2.30 \mathrm{E}-01$ \\
Bone & $2.12 \mathrm{E}+00$ & $8.75 \mathrm{E}-01$ & $3.31 \mathrm{E}-02$ & $5.13 \mathrm{E}-01$ & $3.13 \mathrm{E}-01$ \\
Liver & $8.09 \mathrm{E}-01$ & $3.32 \mathrm{E}-01$ & $7.48 \mathrm{E}-03$ & $2.02 \mathrm{E}-01$ & $1.23 \mathrm{E}-01$ \\
Thyroid & $1.24 \mathrm{E}+00$ & $4.74 \mathrm{E}-01$ & $1.31 \mathrm{E}-02$ & $3.03 \mathrm{E}-01$ & $1.75 \mathrm{E}-01$ \\
Esophagus & $5.16 \mathrm{E}-01$ & $1.82 \mathrm{E}-01$ & $3.06 \mathrm{E}-03$ & $1.26 \mathrm{E}-01$ & $7.11 \mathrm{E}-02$ \\
Skin & $1.73 \mathrm{E}-01$ & $7.24 \mathrm{E}-02$ & $7.28 \mathrm{E}-03$ & $4.48 \mathrm{E}-02$ & $2.69 \mathrm{E}-02$ \\
Other & $6.32 \mathrm{E}-01$ & $2.35 \mathrm{E}-01$ & $3.96 \mathrm{E}-03$ & $1.47 \mathrm{E}-01$ & $8.62 \mathrm{E}-02$ \\
Breasts & $2.98 \mathrm{E}+00$ & $1.34 \mathrm{E}+00$ & $7.33 \mathrm{E}-02$ & $7.89 \mathrm{E}-01$ & $4.93 \mathrm{E}-01$ \\
\hline Total & $2.92 \mathrm{E}+01$ & $1.13 \mathrm{E}+01$ & $2.90 \mathrm{E}-01$ & $7.05 \mathrm{E}+00$ & $4.19 \mathrm{E}+00$ \\
\hline
\end{tabular}


Table I.25 Effective Dose Contribution by Organ from Reference Female Patient to the Postmenopausal Adipose Female Healthcare Provider for $37 \mathrm{GBq} / \mathrm{m}^{2}$ Surface Contamination $(\mathrm{mSv} / \mathrm{hr})$

\begin{tabular}{|c|ccccc|}
\hline Organ & Co-60 & Ir-192 & Am-241 & Cs-137 & I-131 \\
\hline \hline Gonads & $5.37 \mathrm{E}+00$ & $1.49 \mathrm{E}+00$ & $2.86 \mathrm{E}-02$ & $1.14 \mathrm{E}+00$ & $6.21 \mathrm{E}-01$ \\
Stomach & $5.08 \mathrm{E}+00$ & $2.17 \mathrm{E}+00$ & $5.47 \mathrm{E}-02$ & $1.30 \mathrm{E}+00$ & $7.94 \mathrm{E}-01$ \\
Colon Wall & $5.18 \mathrm{E}+00$ & $1.83 \mathrm{E}+00$ & $2.93 \mathrm{E}-02$ & $1.19 \mathrm{E}+00$ & $6.80 \mathrm{E}-01$ \\
Bladder & $3.69 \mathrm{E}+00$ & $1.23 \mathrm{E}+00$ & $1.97 \mathrm{E}-02$ & $8.48 \mathrm{E}-01$ & $4.81 \mathrm{E}-01$ \\
Lungs & $1.55 \mathrm{E}+00$ & $6.04 \mathrm{E}-01$ & $1.30 \mathrm{E}-02$ & $3.77 \mathrm{E}-01$ & $2.21 \mathrm{E}-01$ \\
Bone & $2.12 \mathrm{E}+00$ & $8.68 \mathrm{E}-01$ & $3.24 \mathrm{E}-02$ & $5.11 \mathrm{E}-01$ & $3.09 \mathrm{E}-01$ \\
Liver & $7.72 \mathrm{E}-01$ & $3.11 \mathrm{E}-01$ & $7.07 \mathrm{E}-03$ & $1.92 \mathrm{E}-01$ & $1.16 \mathrm{E}-01$ \\
Thyroid & $1.14 \mathrm{E}+00$ & $4.58 \mathrm{E}-01$ & $1.22 \mathrm{E}-02$ & $2.92 \mathrm{E}-01$ & $1.72 \mathrm{E}-01$ \\
Esophagus & $5.54 \mathrm{E}-01$ & $1.80 \mathrm{E}-01$ & $2.86 \mathrm{E}-03$ & $1.29 \mathrm{E}-01$ & $7.09 \mathrm{E}-02$ \\
Skin & $1.68 \mathrm{E}-01$ & $6.96 \mathrm{E}-02$ & $6.66 \mathrm{E}-03$ & $4.32 \mathrm{E}-02$ & $2.57 \mathrm{E}-02$ \\
Other & $6.48 \mathrm{E}-01$ & $2.30 \mathrm{E}-01$ & $4.41 \mathrm{E}-03$ & $1.54 \mathrm{E}-01$ & $8.93 \mathrm{E}-02$ \\
Breasts & $2.83 \mathrm{E}+00$ & $1.27 \mathrm{E}+00$ & $6.79 \mathrm{E}-02$ & $7.48 \mathrm{E}-01$ & $4.64 \mathrm{E}-01$ \\
\hline Total & $2.91 \mathrm{E}+01$ & $1.07 \mathrm{E}+01$ & $2.79 \mathrm{E}-01$ & $6.93 \mathrm{E}+00$ & $4.04 \mathrm{E}+00$ \\
\hline
\end{tabular}




\section{APPENDIX J}

\section{EFFECTIVE DOSE TO HEALTHCARE PROVIDER DUE TO}

\section{INTERNALLY CONTAMINATED PATIENT}

Table J.1 Effective Dose Contribution by Organ for Reference Male Healthcare Provider from the Reference Male Patient $(\mu \mathrm{Sv} / \mathrm{hr}) / \mathrm{ALI}$

\begin{tabular}{|c|cccccccc|}
\hline Organ & ${ }^{\mathbf{6 0}} \mathbf{C o}(\mathbf{s})$ & ${ }^{\mathbf{6 0}} \mathbf{C o}(\mathbf{m})$ & ${ }^{\mathbf{1 9 2}} \mathbf{I r}(\mathbf{s})$ & ${ }^{\mathbf{1 9 2}} \mathbf{I r}(\mathbf{m})$ & ${ }^{\mathbf{1 9 2}} \mathbf{I r}(\mathbf{f})$ & ${ }^{\mathbf{2 4 1}} \mathbf{A m}$ & ${ }^{\mathbf{1 3 7}} \mathbf{C s}$ & ${ }^{\mathbf{1 3 1}} \mathbf{I}$ \\
\hline \hline Gonads & 0.030 & 0.184 & 0.083 & 0.098 & 0.250 & $1.16 \mathrm{E}-07$ & 0.078 & 0.026 \\
Stomach & 0.144 & 0.432 & 0.299 & 0.345 & 0.894 & $7.90 \mathrm{E}-07$ & 0.219 & 0.086 \\
Colon Wall & 0.183 & 0.565 & 0.357 & 0.416 & 1.020 & $7.84 \mathrm{E}-07$ & 0.278 & 0.104 \\
Bladder & 0.130 & 0.399 & 0.256 & 0.297 & 0.719 & $5.85 \mathrm{E}-07$ & 0.196 & 0.071 \\
Lungs & 0.039 & 0.120 & 0.076 & 0.093 & 0.217 & $2.24 \mathrm{E}-07$ & 0.058 & 0.023 \\
Bone & 0.049 & 0.153 & 0.099 & 0.119 & 0.290 & $4.23 \mathrm{E}-07$ & 0.074 & 0.029 \\
Liver & 0.021 & 0.067 & 0.043 & 0.052 & 0.108 & $1.25 \mathrm{E}-07$ & 0.031 & 0.013 \\
Thyroid & 0.024 & 0.070 & 0.048 & 0.059 & 0.145 & $1.71 \mathrm{E}-07$ & 0.035 & 0.014 \\
Esophagus & 0.011 & 0.033 & 0.018 & 0.022 & 0.050 & $2.97 \mathrm{E}-08$ & 0.015 & 0.005 \\
Skin & 0.002 & 0.007 & 0.004 & 0.005 & 0.012 & $1.25 \mathrm{E}-08$ & 0.004 & 0.001 \\
Other & 0.034 & 0.105 & 0.062 & 0.077 & 0.170 & $1.36 \mathrm{E}-07$ & 0.050 & 0.019 \\
\hline Total & 0.668 & 2.137 & 1.345 & 1.582 & 3.875 & $3.40 \mathrm{E}-06$ & 1.037 & 0.392 \\
\hline
\end{tabular}

Table J.2 Effective Dose Contribution by Organ for Reference Male Healthcare Provider from the Reference Female Patient ( $\mu \mathrm{Sv} / \mathrm{hr}) / \mathrm{ALI}$

\begin{tabular}{|c|cccccccc|}
\hline Organ & ${ }^{\mathbf{6 0}} \mathbf{C o}(\mathbf{s})$ & ${ }^{\mathbf{6 0}} \mathbf{C o}(\mathbf{m})$ & ${ }^{\mathbf{1 9 2}} \mathbf{I r}(\mathbf{s})$ & ${ }^{\mathbf{1 9 2}} \mathbf{I r}(\mathbf{m})$ & ${ }^{\mathbf{1 9 2}} \mathbf{I r}(\mathbf{f})$ & ${ }^{\mathbf{2 4 1}} \mathbf{A m}$ & ${ }^{\mathbf{1 3 7}} \mathbf{C s}$ & ${ }^{\mathbf{1 3 1}} \mathbf{I}$ \\
\hline \hline Gonads & 0.064 & 0.197 & 0.086 & 0.108 & 0.256 & $1.57 \mathrm{E}-07$ & 0.097 & 0.025 \\
Stomach & 0.154 & 0.466 & 0.298 & 0.377 & 0.968 & $9.09 \mathrm{E}-07$ & 0.228 & 0.088 \\
Colon Wall & 0.196 & 0.609 & 0.368 & 0.463 & 1.093 & $9.37 \mathrm{E}-07$ & 0.339 & 0.106 \\
Bladder & 0.139 & 0.430 & 0.262 & 0.329 & 0.774 & $7.02 \mathrm{E}-07$ & 0.244 & 0.073 \\
Lungs & 0.041 & 0.124 & 0.077 & 0.097 & 0.229 & $2.40 \mathrm{E}-07$ & 0.066 & 0.024 \\
Bone & 0.051 & 0.158 & 0.099 & 0.125 & 0.306 & $4.51 \mathrm{E}-07$ & 0.084 & 0.030 \\
Liver & 0.022 & 0.069 & 0.044 & 0.055 & 0.114 & $1.37 \mathrm{E}-07$ & 0.043 & 0.013 \\
Thyroid & 0.024 & 0.073 & 0.047 & 0.059 & 0.152 & $1.75 \mathrm{E}-07$ & 0.040 & 0.015 \\
Esophagus & 0.011 & 0.033 & 0.018 & 0.022 & 0.056 & $3.73 \mathrm{E}-08$ & 0.017 & 0.006 \\
Skin & 0.002 & 0.008 & 0.004 & 0.006 & 0.013 & $1.39 \mathrm{E}-08$ & 0.004 & 0.001 \\
Other & 0.018 & 0.053 & 0.030 & 0.039 & 0.093 & $7.92 \mathrm{E}-08$ & 0.026 & 0.010 \\
\hline Total & 0.721 & 2.219 & 1.333 & 1.680 & 4.055 & $3.84 \mathrm{E}-06$ & 1.189 & 0.392 \\
\hline
\end{tabular}


Table J.3 Effective Dose Contribution by Organ for Reference Male Healthcare Provider from the Adipose Male Patient ( $\mu \mathrm{Sv} / \mathrm{hr}) / \mathrm{ALI}$

\begin{tabular}{|c|cccccccc|}
\hline Organ & ${ }^{\mathbf{6 0}} \mathbf{C o}(\mathbf{s})$ & ${ }^{\mathbf{6 0}} \mathbf{C o}(\mathbf{m})$ & ${ }^{\mathbf{1 9 2}} \mathbf{I r}(\mathbf{s})$ & ${ }^{\mathbf{1 9 2}} \mathbf{I r}(\mathbf{m})$ & ${ }^{\mathbf{1 9 2}} \mathbf{I r}(\mathbf{f})$ & ${ }^{\mathbf{2 4 1}} \mathbf{A m}$ & ${ }^{\mathbf{1 3 7}} \mathbf{C s}$ & ${ }^{\mathbf{1 3 1}} \mathbf{I}$ \\
\hline \hline Gonads & 0.068 & 0.207 & 0.099 & 0.127 & 0.341 & $1.82 \mathrm{E}-07$ & 0.097 & 0.030 \\
Stomach & 0.133 & 0.404 & 0.245 & 0.311 & 0.921 & $5.90 \mathrm{E}-07$ & 0.226 & 0.076 \\
Colon Wall & 0.175 & 0.542 & 0.312 & 0.397 & 1.082 & $6.37 \mathrm{E}-07$ & 0.289 & 0.096 \\
Bladder & 0.124 & 0.389 & 0.234 & 0.296 & 0.804 & $5.41 \mathrm{E}-07$ & 0.207 & 0.068 \\
Lungs & 0.034 & 0.106 & 0.061 & 0.078 & 0.213 & $1.53 \mathrm{E}-07$ & 0.057 & 0.021 \\
Bone & 0.045 & 0.141 & 0.085 & 0.107 & 0.292 & $3.07 \mathrm{E}-07$ & 0.074 & 0.027 \\
Liver & 0.020 & 0.062 & 0.037 & 0.047 & 0.112 & $9.66 \mathrm{E}-08$ & 0.032 & 0.012 \\
Thyroid & 0.019 & 0.060 & 0.035 & 0.042 & 0.136 & $9.77 \mathrm{E}-08$ & 0.034 & 0.013 \\
Esophagus & 0.009 & 0.028 & 0.014 & 0.017 & 0.049 & $1.98 \mathrm{E}-08$ & 0.014 & 0.005 \\
Skin & 0.002 & 0.007 & 0.004 & 0.005 & 0.013 & $9.70 \mathrm{E}-09$ & 0.004 & 0.001 \\
Other & 0.015 & 0.045 & 0.026 & 0.033 & 0.084 & $5.12 \mathrm{E}-08$ & 0.024 & 0.008 \\
\hline Total & 0.644 & 1.991 & 1.152 & 1.461 & 4.047 & $2.69 \mathrm{E}-06$ & 1.057 & 0.356 \\
\hline
\end{tabular}

Table J.4 Effective Dose Contribution by Organ for Reference Male Healthcare Provider from the Adipose Female Patient $(\mu \mathrm{Sv} / \mathrm{hr}) / \mathrm{ALI}$

\begin{tabular}{|c|cccccccc|}
\hline Organ & ${ }^{\mathbf{6 0}} \mathbf{C o}(\mathbf{s})$ & ${ }^{\mathbf{6 0}} \mathbf{C o}(\mathbf{m})$ & ${ }^{\mathbf{1 9 2}} \mathbf{I r}(\mathbf{s})$ & ${ }^{\mathbf{1 9 2}} \mathbf{I r}(\mathbf{m})$ & ${ }^{\mathbf{1 9 2}} \mathbf{I r}(\mathbf{f})$ & ${ }^{\mathbf{2 4 1}} \mathbf{A m}$ & ${ }^{\mathbf{1 3 7}} \mathbf{C s}$ & ${ }^{\mathbf{1 3 1}} \mathbf{I}$ \\
\hline \hline Gonads & 0.067 & 0.209 & 0.093 & 0.118 & 0.282 & $1.59 \mathrm{E}-07$ & 0.086 & 0.028 \\
Stomach & 0.147 & 0.443 & 0.280 & 0.357 & 1.005 & $7.86 \mathrm{E}-07$ & 0.244 & 0.086 \\
Colon Wall & 0.189 & 0.588 & 0.350 & 0.440 & 1.133 & $8.37 \mathrm{E}-07$ & 0.300 & 0.105 \\
Bladder & 0.136 & 0.422 & 0.252 & 0.318 & 0.790 & $6.35 \mathrm{E}-07$ & 0.211 & 0.072 \\
Lungs & 0.037 & 0.114 & 0.067 & 0.086 & 0.228 & $1.85 \mathrm{E}-07$ & 0.059 & 0.022 \\
Bone & 0.048 & 0.149 & 0.091 & 0.115 & 0.303 & $3.57 \mathrm{E}-07$ & 0.076 & 0.028 \\
Liver & 0.021 & 0.066 & 0.041 & 0.052 & 0.117 & $1.17 \mathrm{E}-07$ & 0.033 & 0.013 \\
Thyroid & 0.021 & 0.067 & 0.039 & 0.050 & 0.145 & $1.18 \mathrm{E}-07$ & 0.036 & 0.015 \\
Esophagus & 0.010 & 0.030 & 0.016 & 0.020 & 0.054 & $2.78 \mathrm{E}-08$ & 0.015 & 0.005 \\
Skin & 0.002 & 0.007 & 0.004 & 0.005 & 0.013 & $1.16 \mathrm{E}-08$ & 0.004 & 0.001 \\
Other & 0.016 & 0.048 & 0.027 & 0.035 & 0.103 & $6.05 \mathrm{E}-08$ & 0.026 & 0.009 \\
\hline Total & 0.692 & 2.144 & 1.260 & 1.595 & 4.173 & $3.29 \mathrm{E}-06$ & 1.090 & 0.385 \\
\hline
\end{tabular}


Table J.5 Effective Dose Contribution by Organ for Reference Male Healthcare Provider from the Postmenopausal Adipose Female Patient $(\mu \mathrm{Sv} / \mathrm{hr}) / \mathrm{ALI}$

\begin{tabular}{|c|cccccccc|}
\hline Organ & ${ }^{60} \mathbf{C o}(\mathbf{s})$ & ${ }^{60} \mathbf{C o}(\mathbf{m})$ & ${ }^{192} \mathbf{I r}(\mathbf{s})$ & ${ }^{192} \mathbf{I r}(\mathbf{m})$ & ${ }^{192} \mathbf{I r}(\mathbf{f})$ & ${ }^{241} \mathbf{A m}$ & ${ }^{137} \mathbf{C s}$ & ${ }^{131} \mathbf{I}$ \\
\hline \hline Gonads & 0.069 & 0.212 & 0.100 & 0.126 & 0.441 & $1.78 \mathrm{E}-07$ & 0.156 & 0.028 \\
Stomach & 0.141 & 0.428 & 0.265 & 0.337 & 1.046 & $6.78 \mathrm{E}-07$ & 0.350 & 0.081 \\
Colon Wall & 0.182 & 0.567 & 0.334 & 0.421 & 1.446 & $7.29 \mathrm{E}-07$ & 0.451 & 0.100 \\
Bladder & 0.130 & 0.407 & 0.247 & 0.310 & 1.063 & $6.16 \mathrm{E}-07$ & 0.312 & 0.071 \\
Lungs & 0.036 & 0.111 & 0.064 & 0.081 & 0.257 & $1.65 \mathrm{E}-07$ & 0.088 & 0.021 \\
Bone & 0.047 & 0.145 & 0.087 & 0.111 & 0.359 & $3.21 \mathrm{E}-07$ & 0.116 & 0.027 \\
Liver & 0.020 & 0.064 & 0.039 & 0.049 & 0.169 & $1.04 \mathrm{E}-07$ & 0.048 & 0.012 \\
Thyroid & 0.020 & 0.061 & 0.037 & 0.047 & 0.147 & $1.01 \mathrm{E}-07$ & 0.051 & 0.013 \\
Esophagus & 0.010 & 0.029 & 0.015 & 0.019 & 0.057 & $2.41 \mathrm{E}-08$ & 0.022 & 0.005 \\
Skin & 0.002 & 0.007 & 0.004 & 0.005 & 0.016 & $1.03 \mathrm{E}-08$ & 0.006 & 0.001 \\
Other & 0.015 & 0.046 & 0.025 & 0.033 & 0.108 & $5.49 \mathrm{E}-08$ & 0.039 & 0.009 \\
\hline Total & 0.673 & 2.078 & 1.216 & 1.539 & 5.109 & $2.98 \mathrm{E}-06$ & 1.638 & 0.369 \\
\hline
\end{tabular}

Table J.6 Effective Dose Contribution by Organ for Reference Female Healthcare Provider from the Reference Male Patient $(\mu \mathrm{Sv} / \mathrm{hr}) / \mathrm{ALI}$

\begin{tabular}{|c|cccccccc|}
\hline Organ & ${ }^{\mathbf{6 0}} \mathbf{C o}(\mathbf{s})$ & ${ }^{\mathbf{6 0}} \mathbf{C o}(\mathbf{m})$ & ${ }^{192} \mathbf{I r}(\mathbf{s})$ & ${ }^{\mathbf{1 9 2}} \mathbf{I r}(\mathbf{m})$ & ${ }^{\mathbf{1 9 2}} \mathbf{I r}(\mathbf{f})$ & ${ }^{241} \mathbf{A m}$ & ${ }^{{ }^{337}} \mathbf{C s}$ & ${ }^{\mathbf{1 3 1}} \mathbf{I}$ \\
\hline \hline Gonads & 0.076 & 0.230 & 0.143 & 0.166 & 0.425 & $2.32 \mathrm{E}-07$ & 0.114 & 0.398 \\
Stomach & 0.134 & 0.403 & 0.276 & 0.316 & 0.822 & $7.40 \mathrm{E}-07$ & 0.205 & 0.796 \\
Colon Wall & 0.155 & 0.483 & 0.300 & 0.351 & 0.877 & $6.73 \mathrm{E}-07$ & 0.240 & 0.892 \\
Bladder & 0.129 & 0.396 & 0.249 & 0.289 & 0.703 & $5.57 \mathrm{E}-07$ & 0.190 & 0.691 \\
Lungs & 0.040 & 0.123 & 0.076 & 0.092 & 0.215 & $2.04 \mathrm{E}-07$ & 0.060 & 0.234 \\
Bone & 0.053 & 0.162 & 0.104 & 0.125 & 0.306 & $4.37 \mathrm{E}-07$ & 0.078 & 0.307 \\
Liver & 0.022 & 0.070 & 0.045 & 0.055 & 0.115 & $1.30 \mathrm{E}-07$ & 0.033 & 0.133 \\
Thyroid & 0.021 & 0.063 & 0.043 & 0.054 & 0.131 & $1.61 \mathrm{E}-07$ & 0.031 & 0.135 \\
Esophagus & 0.013 & 0.041 & 0.022 & 0.027 & 0.067 & $4.03 \mathrm{E}-08$ & 0.019 & 0.069 \\
Skin & 0.004 & 0.011 & 0.006 & 0.008 & 0.019 & $1.79 \mathrm{E}-08$ & 0.005 & 0.020 \\
Other & 0.018 & 0.053 & 0.031 & 0.038 & 0.096 & $7.34 \mathrm{E}-08$ & 0.026 & 0.101 \\
Breast & 0.066 & 0.202 & 0.139 & 0.168 & 0.380 & $5.07 \mathrm{E}-07$ & 0.098 & 0.406 \\
\hline Total & 0.730 & 2.239 & 1.435 & 1.690 & 4.157 & $3.77 \mathrm{E}-06$ & 1.099 & 4.182 \\
\hline
\end{tabular}


Table J.7 Effective Dose Contribution by Organ for Reference Female Healthcare Provider from the Reference Female Patient $(\mu \mathrm{Sv} / \mathrm{hr}) /$ ALI

\begin{tabular}{|c|cccccccc|}
\hline Organ & ${ }^{60} \mathbf{C o}(\mathbf{s})$ & ${ }^{60} \mathbf{C o}(\mathbf{m})$ & ${ }^{192} \mathbf{I r}(\mathbf{s})$ & ${ }^{192} \mathbf{I r}(\mathbf{m})$ & ${ }^{192} \mathbf{I r}(\mathbf{f})$ & ${ }^{241} \mathbf{A m}$ & ${ }^{137} \mathbf{C s}$ & ${ }^{131} \mathbf{I}$ \\
\hline \hline Gonads & 0.081 & 0.242 & 0.140 & 0.176 & 0.442 & $3.27 \mathrm{E}-07$ & 0.142 & 0.043 \\
Stomach & 0.141 & 0.429 & 0.279 & 0.353 & 0.893 & $8.63 \mathrm{E}-07$ & 0.215 & 0.082 \\
Colon Wall & 0.168 & 0.520 & 0.315 & 0.395 & 0.932 & $8.01 \mathrm{E}-07$ & 0.289 & 0.090 \\
Bladder & 0.136 & 0.422 & 0.255 & 0.321 & 0.747 & $6.69 \mathrm{E}-07$ & 0.241 & 0.071 \\
Lungs & 0.041 & 0.127 & 0.076 & 0.096 & 0.225 & $2.15 \mathrm{E}-07$ & 0.069 & 0.025 \\
Bone & 0.054 & 0.168 & 0.104 & 0.131 & 0.322 & $4.72 \mathrm{E}-07$ & 0.089 & 0.031 \\
Liver & 0.023 & 0.073 & 0.047 & 0.059 & 0.122 & $1.43 \mathrm{E}-07$ & 0.046 & 0.014 \\
Thyroid & 0.021 & 0.064 & 0.044 & 0.055 & 0.131 & $1.62 \mathrm{E}-07$ & 0.035 & 0.014 \\
Esophagus & 0.014 & 0.044 & 0.023 & 0.028 & 0.069 & $4.54 \mathrm{E}-08$ & 0.020 & 0.007 \\
Skin & 0.004 & 0.012 & 0.006 & 0.008 & 0.020 & $1.96 \mathrm{E}-08$ & 0.006 & 0.002 \\
Other & 0.018 & 0.054 & 0.032 & 0.041 & 0.096 & $7.61 \mathrm{E}-08$ & 0.029 & 0.010 \\
Breast & 0.068 & 0.206 & 0.138 & 0.174 & 0.403 & $5.41 \mathrm{E}-07$ & 0.115 & 0.074 \\
\hline Total & 0.769 & 2.362 & 1.459 & 1.838 & 4.400 & $4.33 \mathrm{E}-06$ & 1.295 & 0.465 \\
\hline
\end{tabular}

Table J.8 Effective Dose Contribution by Organ for Reference Female Healthcare Provider from the Adipose Male Patient ( $\mu \mathrm{Sv} / \mathrm{hr}) / \mathrm{ALI}$

\begin{tabular}{|c|cccccccc|}
\hline Organ & ${ }^{6 \mathbf{C o}} \mathbf{( s )}$ & ${ }^{\mathbf{6 0}} \mathbf{C o}(\mathbf{m})$ & ${ }^{192} \mathbf{I r}(\mathbf{s})$ & ${ }^{\mathbf{1 9 2}} \mathbf{I r}(\mathbf{m})$ & ${ }^{192} \mathbf{I r}(\mathbf{f})$ & ${ }^{\mathbf{2 4 1}} \mathbf{A m}$ & ${ }^{137} \mathbf{C s}$ & ${ }^{\mathbf{1 3 1}} \mathbf{I}$ \\
\hline \hline Gonads & 0.070 & 0.220 & 0.119 & 0.153 & 0.416 & $2.10 \mathrm{E}-07$ & 0.114 & 0.040 \\
Stomach & 0.124 & 0.375 & 0.227 & 0.289 & 0.866 & $5.75 \mathrm{E}-07$ & 0.211 & 0.071 \\
Colon Wall & 0.148 & 0.463 & 0.265 & 0.336 & 0.929 & $5.43 \mathrm{E}-07$ & 0.245 & 0.082 \\
Bladder & 0.124 & 0.387 & 0.230 & 0.289 & 0.787 & $5.23 \mathrm{E}-07$ & 0.203 & 0.068 \\
Lungs & 0.036 & 0.111 & 0.062 & 0.078 & 0.213 & $1.44 \mathrm{E}-07$ & 0.059 & 0.021 \\
Bone & 0.048 & 0.150 & 0.090 & 0.114 & 0.310 & $3.25 \mathrm{E}-07$ & 0.079 & 0.028 \\
Liver & 0.021 & 0.066 & 0.040 & 0.050 & 0.121 & $1.03 \mathrm{E}-07$ & 0.034 & 0.012 \\
Thyroid & 0.017 & 0.054 & 0.033 & 0.041 & 0.119 & $9.13 \mathrm{E}-08$ & 0.033 & 0.012 \\
Esophagus & 0.012 & 0.036 & 0.018 & 0.023 & 0.065 & $2.89 \mathrm{E}-08$ & 0.018 & 0.006 \\
Skin & 0.003 & 0.010 & 0.005 & 0.007 & 0.019 & $1.38 \mathrm{E}-08$ & 0.005 & 0.002 \\
Other & 0.016 & 0.050 & 0.111 & 0.034 & 0.095 & $6.23 \mathrm{E}-08$ & 0.025 & 0.009 \\
Breast & 0.058 & 0.179 & 1.227 & 0.141 & 0.380 & $3.56 \mathrm{E}-07$ & 0.099 & 0.036 \\
\hline Total & 0.677 & 2.102 & 2.427 & 1.557 & 4.320 & $2.97 \mathrm{E}-06$ & 1.124 & 0.387 \\
\hline
\end{tabular}


Table J.9 Effective Dose Contribution by Organ for Reference Female Healthcare Provider from the Adipose Female Patient $(\mu \mathrm{Sv} / \mathrm{hr}) /$ ALI

\begin{tabular}{|c|cccccccc|}
\hline Organ & ${ }^{\mathbf{6 0}} \mathbf{C o}(\mathbf{s})$ & ${ }^{\mathbf{6 0}} \mathbf{C o}(\mathbf{m})$ & ${ }^{192} \mathbf{I r}(\mathbf{s})$ & ${ }^{192} \mathbf{I r}(\mathbf{m})$ & ${ }^{192} \mathbf{I r}(\mathbf{f})$ & ${ }^{241} \mathbf{A m}$ & ${ }^{137} \mathbf{C s}$ & ${ }^{131} \mathbf{I}$ \\
\hline \hline Gonads & 0.076 & 0.235 & 0.137 & 0.168 & 0.581 & $2.34 \mathrm{E}-07$ & 0.127 & 0.048 \\
Stomach & 0.136 & 0.411 & 0.263 & 0.335 & 1.024 & $7.37 \mathrm{E}-07$ & 0.227 & 0.089 \\
Colon Wall & 0.160 & 0.494 & 0.295 & 0.371 & 1.251 & $7.09 \mathrm{E}-07$ & 0.258 & 0.101 \\
Bladder & 0.133 & 0.415 & 0.246 & 0.310 & 1.034 & $5.99 \mathrm{E}-07$ & 0.207 & 0.079 \\
Lungs & 0.038 & 0.120 & 0.069 & 0.087 & 0.275 & $1.76 \mathrm{E}-07$ & 0.061 & 0.026 \\
Bone & 0.051 & 0.159 & 0.097 & 0.122 & 0.389 & $3.78 \mathrm{E}-07$ & 0.081 & 0.034 \\
Liver & 0.022 & 0.070 & 0.044 & 0.056 & 0.186 & $1.24 \mathrm{E}-07$ & 0.035 & 0.015 \\
Thyroid & 0.019 & 0.058 & 0.036 & 0.045 & 0.142 & $1.05 \mathrm{E}-07$ & 0.032 & 0.015 \\
Esophagus & 0.013 & 0.040 & 0.020 & 0.025 & 0.080 & $3.59 \mathrm{E}-08$ & 0.019 & 0.008 \\
Skin & 0.003 & 0.011 & 0.006 & 0.008 & 0.024 & $1.64 \mathrm{E}-08$ & 0.006 & 0.002 \\
Other & 0.018 & 0.055 & 0.029 & 0.037 & 0.124 & $6.19 \mathrm{E}-08$ & 0.027 & 0.011 \\
Breast & 0.062 & 0.191 & 0.123 & 0.156 & 0.497 & $4.24 \mathrm{E}-07$ & 0.103 & 0.044 \\
\hline Total & 0.730 & 2.258 & 1.365 & 1.720 & 5.607 & $3.60 \mathrm{E}-06$ & 1.184 & 0.471 \\
\hline
\end{tabular}

Table J.10 Effective Dose Contribution by Organ for Reference Female Healthcare Provider from the Postmenopausal Adipose Female Patient $(\mu \mathrm{Sv} / \mathrm{hr}) / \mathrm{ALI}$

\begin{tabular}{|c|cccccccc|}
\hline Organ & ${ }^{60} \mathbf{C o}(\mathbf{s})$ & ${ }^{60} \mathbf{C o}(\mathbf{m})$ & ${ }^{192} \mathbf{I r}(\mathbf{s})$ & ${ }^{{ }^{192}} \mathbf{I r}(\mathbf{m})$ & ${ }^{\mathbf{1 9 2}} \mathbf{I r}(\mathbf{f})$ & ${ }^{241} \mathbf{A m}$ & ${ }^{\mathbf{1 3 7}} \mathbf{C s}$ & ${ }^{131} \mathbf{I}$ \\
\hline \hline Gonads & 0.073 & 0.228 & 0.132 & 0.167 & 0.407 & $2.54 \mathrm{E}-07$ & 0.184 & 0.039 \\
Stomach & 0.130 & 0.396 & 0.250 & 0.318 & 0.880 & $6.33 \mathrm{E}-07$ & 0.325 & 0.076 \\
Colon Wall & 0.156 & 0.486 & 0.286 & 0.360 & 0.938 & $6.33 \mathrm{E}-07$ & 0.384 & 0.085 \\
Bladder & 0.130 & 0.404 & 0.241 & 0.304 & 0.777 & $5.97 \mathrm{E}-07$ & 0.310 & 0.069 \\
Lungs & 0.037 & 0.115 & 0.065 & 0.082 & 0.215 & $1.56 \mathrm{E}-07$ & 0.092 & 0.022 \\
Bone & 0.050 & 0.155 & 0.093 & 0.118 & 0.309 & $3.42 \mathrm{E}-07$ & 0.123 & 0.029 \\
Liver & 0.021 & 0.067 & 0.042 & 0.052 & 0.119 & $1.10 \mathrm{E}-07$ & 0.051 & 0.013 \\
Thyroid & 0.017 & 0.054 & 0.033 & 0.043 & 0.121 & $1.00 \mathrm{E}-07$ & 0.046 & 0.012 \\
Esophagus & 0.012 & 0.040 & 0.018 & 0.023 & 0.067 & $3.20 \mathrm{E}-08$ & 0.028 & 0.006 \\
Skin & 0.003 & 0.010 & 0.006 & 0.007 & 0.019 & $1.47 \mathrm{E}-08$ & 0.008 & 0.002 \\
Other & 0.016 & 0.050 & 0.028 & 0.035 & 0.095 & $5.43 \mathrm{E}-08$ & 0.041 & 0.009 \\
Breast & 0.060 & 0.187 & 0.118 & 0.150 & 0.383 & $3.87 \mathrm{E}-07$ & 0.148 & 0.037 \\
\hline Total & 0.707 & 2.193 & 1.311 & 1.660 & 4.330 & $3.31 \mathrm{E}-06$ & 1.742 & 0.399 \\
\hline
\end{tabular}


Table J.11 Effective Dose Contribution by Organ for Adipose Male Healthcare Provider from the Reference Male Patient ( $\mu \mathrm{Sv} / \mathrm{hr}) / \mathrm{ALI}$

\begin{tabular}{|c|cccccccc|}
\hline Organ & ${ }^{\mathbf{6 0}} \mathbf{C o}(\mathbf{s})$ & ${ }^{\mathbf{6 0}} \mathbf{C o}(\mathbf{m})$ & ${ }^{\mathbf{1 9 2}} \mathbf{I r}(\mathbf{s})$ & ${ }^{\mathbf{1 9 2}} \mathbf{I r}(\mathbf{m})$ & ${ }^{\mathbf{1 9 2}^{\mathbf{I}} \mathbf{( f )}}$ & ${ }^{\mathbf{2 4 1}} \mathbf{A m}$ & ${ }^{\mathbf{1 3 7}} \mathbf{C s}$ & ${ }^{\mathbf{1 3 1}} \mathbf{I}$ \\
\hline \hline Gonads & 0.097 & 0.300 & 0.166 & 0.198 & 0.469 & $3.66 \mathrm{E}-07$ & 0.131 & 0.049 \\
Stomach & 0.112 & 0.332 & 0.199 & 0.227 & 0.617 & $3.94 \mathrm{E}-07$ & 0.160 & 0.060 \\
Colon Wall & 0.115 & 0.358 & 0.181 & 0.211 & 0.546 & $2.30 \mathrm{E}-07$ & 0.164 & 0.058 \\
Bladder & 0.079 & 0.247 & 0.131 & 0.152 & 0.385 & $1.75 \mathrm{E}-07$ & 0.112 & 0.039 \\
Lungs & 0.035 & 0.107 & 0.063 & 0.077 & 0.178 & $1.53 \mathrm{E}-07$ & 0.049 & 0.019 \\
Bone & 0.046 & 0.143 & 0.090 & 0.108 & 0.263 & $3.25 \mathrm{E}-07$ & 0.068 & 0.027 \\
Liver & 0.018 & 0.058 & 0.034 & 0.041 & 0.080 & $8.20 \mathrm{E}-08$ & 0.026 & 0.010 \\
Thyroid & 0.020 & 0.061 & 0.037 & 0.046 & 0.107 & $1.05 \mathrm{E}-07$ & 0.030 & 0.011 \\
Esophagus & 0.009 & 0.029 & 0.015 & 0.018 & 0.041 & $2.63 \mathrm{E}-08$ & 0.012 & 0.005 \\
Skin & 0.003 & 0.008 & 0.005 & 0.006 & 0.014 & $1.41 \mathrm{E}-08$ & 0.004 & 0.002 \\
Other & 0.012 & 0.037 & 0.022 & 0.026 & 0.055 & $3.47 \mathrm{E}-08$ & 0.017 & 0.006 \\
Breast & 0.041 & 0.122 & 0.079 & 0.105 & 0.226 & $3.08 \mathrm{E}-07$ & 0.058 & 0.024 \\
\hline Total & 0.587 & 1.801 & 1.021 & 1.215 & 2.982 & $2.21 \mathrm{E}-06$ & 0.830 & 0.311 \\
\hline
\end{tabular}

Table J.12 Effective Dose Contribution by Organ for Adipose Male Healthcare Provider from the Reference Female Patient $(\mu \mathrm{Sv} / \mathrm{hr}) / \mathrm{ALI}$

\begin{tabular}{|c|cccccccc|}
\hline Organ & ${ }^{\mathbf{6 0}} \mathbf{C o}(\mathbf{s})$ & ${ }^{\mathbf{6 0}} \mathbf{C o}(\mathbf{m})$ & ${ }^{\mathbf{1 9 2}} \mathbf{I r}(\mathbf{s})$ & ${ }^{\mathbf{1 9 2}} \mathbf{I r}(\mathbf{m})$ & ${ }^{\mathbf{1 9 2}} \mathbf{I r}(\mathbf{f})$ & ${ }^{\mathbf{2 4 1}} \mathbf{A m}$ & ${ }^{\mathbf{1 3 7}} \mathbf{C s}$ & ${ }^{\mathbf{1 3 1}} \mathbf{I}$ \\
\hline \hline Gonads & 0.091 & 0.279 & 0.143 & 0.187 & 0.393 & $3.01 \mathrm{E}-07$ & 0.152 & 0.041 \\
Stomach & 0.117 & 0.352 & 0.192 & 0.207 & 0.675 & $4.56 \mathrm{E}-07$ & 0.144 & 0.061 \\
Colon Wall & 0.122 & 0.382 & 0.179 & 0.194 & 0.558 & $2.52 \mathrm{E}-07$ & 0.189 & 0.057 \\
Bladder & 0.085 & 0.266 & 0.127 & 0.137 & 0.388 & $1.81 \mathrm{E}-07$ & 0.135 & 0.037 \\
Lungs & 0.036 & 0.111 & 0.063 & 0.064 & 0.189 & $1.64 \mathrm{E}-07$ & 0.057 & 0.020 \\
Bone & 0.046 & 0.144 & 0.086 & 0.094 & 0.265 & $3.27 \mathrm{E}-07$ & 0.076 & 0.027 \\
Liver & 0.019 & 0.059 & 0.035 & 0.037 & 0.084 & $8.79 \mathrm{E}-08$ & 0.037 & 0.011 \\
Thyroid & 0.020 & 0.063 & 0.037 & 0.036 & 0.119 & $1.25 \mathrm{E}-07$ & 0.033 & 0.013 \\
Esophagus & 0.010 & 0.029 & 0.014 & 0.014 & 0.045 & $2.58 \mathrm{E}-08$ & 0.014 & 0.005 \\
Skin & 0.003 & 0.009 & 0.005 & 0.005 & 0.015 & $1.49 \mathrm{E}-08$ & 0.005 & 0.001 \\
Other & 0.012 & 0.036 & 0.018 & 0.023 & 0.060 & $3.87 \mathrm{E}-08$ & 0.035 & 0.006 \\
Breast & 0.036 & 0.106 & 0.082 & 0.103 & 0.238 & $3.60 \mathrm{E}-07$ & 0.124 & 0.025 \\
\hline Total & 0.598 & 1.837 & 0.982 & 1.101 & 3.031 & $2.33 \mathrm{E}-06$ & 1.001 & 0.304 \\
\hline
\end{tabular}


Table J.13 Effective Dose Contribution by Organ for Adipose Male Healthcare Provider from the Adipose Male Patient $(\mu \mathrm{Sv} / \mathrm{hr}) / \mathrm{ALI}$

\begin{tabular}{|c|cccccccc|}
\hline Organ & ${ }^{\mathbf{6 0}} \mathbf{C o}(\mathbf{s})$ & ${ }^{\mathbf{6 0}} \mathbf{C o}(\mathbf{m})$ & ${ }^{\mathbf{1 9 2}} \mathbf{I r}(\mathbf{s})$ & ${ }^{\mathbf{1 9 2}} \mathbf{I r}(\mathbf{m})$ & ${ }^{\mathbf{1 9 2}} \mathbf{I r}(\mathbf{f})$ & ${ }^{\mathbf{2 4 1}} \mathbf{A m}$ & ${ }^{\mathbf{1 3 7}} \mathbf{C s}$ & ${ }^{\mathbf{1 3 1}} \mathbf{I}$ \\
\hline \hline Gonads & 0.091 & 0.280 & 0.148 & 0.187 & 0.429 & $2.81 \mathrm{E}-07$ & 0.124 & 0.039 \\
Stomach & 0.102 & 0.307 & 0.162 & 0.207 & 0.644 & $2.94 \mathrm{E}-07$ & 0.166 & 0.054 \\
Colon Wall & 0.105 & 0.333 & 0.153 & 0.194 & 0.548 & $1.86 \mathrm{E}-07$ & 0.166 & 0.052 \\
Bladder & 0.074 & 0.231 & 0.109 & 0.137 & 0.374 & $1.34 \mathrm{E}-07$ & 0.109 & 0.033 \\
Lungs & 0.030 & 0.095 & 0.050 & 0.064 & 0.174 & $1.03 \mathrm{E}-07$ & 0.049 & 0.017 \\
Bone & 0.041 & 0.129 & 0.074 & 0.094 & 0.253 & $2.27 \mathrm{E}-07$ & 0.066 & 0.024 \\
Liver & 0.017 & 0.054 & 0.029 & 0.037 & 0.085 & $6.25 \mathrm{E}-08$ & 0.026 & 0.009 \\
Thyroid & 0.017 & 0.052 & 0.028 & 0.036 & 0.104 & $6.66 \mathrm{E}-08$ & 0.029 & 0.010 \\
Esophagus & 0.008 & 0.025 & 0.011 & 0.014 & 0.043 & $1.23 \mathrm{E}-08$ & 0.012 & 0.004 \\
Skin & 0.002 & 0.008 & 0.004 & 0.005 & 0.014 & $1.06 \mathrm{E}-08$ & 0.004 & 0.001 \\
Other & 0.010 & 0.031 & 0.016 & 0.020 & 0.054 & $2.28 \mathrm{E}-08$ & 0.016 & 0.005 \\
Breast & 0.035 & 0.103 & 0.065 & 0.080 & 0.228 & $2.22 \mathrm{E}-07$ & 0.061 & 0.020 \\
\hline Total & 0.534 & 1.647 & 0.850 & 1.075 & 2.949 & $1.62 \mathrm{E}-06$ & 0.830 & 0.270 \\
\hline
\end{tabular}

Table J.14 Effective Dose Contribution by Organ for Adipose Male Healthcare Provider from the Adipose Female Patient $(\mu \mathrm{Sv} / \mathrm{hr}) / \mathrm{ALI}$

\begin{tabular}{|c|cccccccc|}
\hline Organ & ${ }^{\mathbf{6 0}} \mathbf{C o}(\mathbf{s})$ & ${ }^{\mathbf{6 0}} \mathbf{C o}(\mathbf{m})$ & ${ }^{\mathbf{1 9 2}} \mathbf{I r}(\mathbf{s})$ & ${ }^{\mathbf{1 9 2}} \mathbf{I r}(\mathbf{m})$ & ${ }^{\mathbf{1 9 2}} \mathbf{I r}(\mathbf{f})$ & ${ }^{\mathbf{2 4 1}} \mathbf{A m}$ & ${ }^{\mathbf{1 3 7}} \mathbf{C s}$ & ${ }^{\mathbf{1 3 1}} \mathbf{I}$ \\
\hline \hline Gonads & 0.088 & 0.270 & 0.140 & 0.174 & 0.365 & $2.90 \mathrm{E}-07$ & 0.118 & 0.044 \\
Stomach & 0.113 & 0.338 & 0.181 & 0.233 & 0.706 & $3.88 \mathrm{E}-07$ & 0.179 & 0.068 \\
Colon Wall & 0.116 & 0.364 & 0.169 & 0.212 & 0.573 & $2.30 \mathrm{E}-07$ & 0.174 & 0.062 \\
Bladder & 0.081 & 0.255 & 0.119 & 0.151 & 0.387 & $1.56 \mathrm{E}-07$ & 0.115 & 0.040 \\
Lungs & 0.033 & 0.101 & 0.055 & 0.071 & 0.188 & $1.22 \mathrm{E}-07$ & 0.051 & 0.021 \\
Bone & 0.043 & 0.136 & 0.079 & 0.100 & 0.263 & $2.57 \mathrm{E}-07$ & 0.068 & 0.028 \\
Liver & 0.018 & 0.057 & 0.032 & 0.040 & 0.087 & $7.48 \mathrm{E}-08$ & 0.027 & 0.012 \\
Thyroid & 0.018 & 0.057 & 0.031 & 0.040 & 0.112 & $7.90 \mathrm{E}-08$ & 0.028 & 0.013 \\
Esophagus & 0.009 & 0.027 & 0.013 & 0.016 & 0.046 & $1.96 \mathrm{E}-08$ & 0.013 & 0.005 \\
Skin & 0.003 & 0.008 & 0.005 & 0.006 & 0.015 & $1.25 \mathrm{E}-08$ & 0.004 & 0.002 \\
Other & 0.011 & 0.034 & 0.017 & 0.022 & 0.064 & $2.77 \mathrm{E}-08$ & 0.018 & 0.007 \\
Breast & 0.031 & 0.103 & 0.075 & 0.099 & 0.233 & $2.89 \mathrm{E}-07$ & 0.064 & 0.025 \\
\hline Total & 0.563 & 1.751 & 0.915 & 1.164 & 3.038 & $1.95 \mathrm{E}-06$ & 0.859 & 0.326 \\
\hline
\end{tabular}


Table J.15 Effective Dose Contribution by Organ for Adipose Male Healthcare Provider from the Postmenopausal Adipose Female Patient ( $\mu \mathrm{Sv} / \mathrm{hr}) / \mathrm{ALI}$

\begin{tabular}{|c|cccccccc|}
\hline Organ & ${ }^{\mathbf{6 0}} \mathbf{C o}(\mathbf{s})$ & ${ }^{\mathbf{6 0}} \mathbf{C o}(\mathbf{m})$ & ${ }^{\mathbf{1 9 2}} \mathbf{I r}(\mathbf{s})$ & ${ }^{\mathbf{1 9 2}} \mathbf{I r}(\mathbf{m})$ & ${ }^{\mathbf{1 9 2}} \mathbf{I r}(\mathbf{f})$ & ${ }^{\mathbf{2 4 1}} \mathbf{A m}$ & ${ }^{\mathbf{1 3 7}} \mathbf{C s}$ & ${ }^{\mathbf{1 3 1}} \mathbf{I}$ \\
\hline \hline Gonads & 0.094 & 0.285 & 0.148 & 0.184 & 0.573 & $2.82 \mathrm{E}-07$ & 0.196 & 0.041 \\
Stomach & 0.107 & 0.323 & 0.171 & 0.219 & 0.641 & $3.40 \mathrm{E}-07$ & 0.271 & 0.057 \\
Colon Wall & 0.111 & 0.347 & 0.159 & 0.202 & 0.700 & $1.91 \mathrm{E}-07$ & 0.279 & 0.053 \\
Bladder & 0.077 & 0.240 & 0.113 & 0.142 & 0.496 & $1.49 \mathrm{E}-07$ & 0.183 & 0.034 \\
Lungs & 0.032 & 0.099 & 0.053 & 0.067 & 0.211 & $1.13 \mathrm{E}-07$ & 0.078 & 0.018 \\
Bone & 0.042 & 0.132 & 0.076 & 0.096 & 0.310 & $2.33 \mathrm{E}-07$ & 0.105 & 0.024 \\
Liver & 0.017 & 0.055 & 0.030 & 0.038 & 0.132 & $6.45 \mathrm{E}-08$ & 0.041 & 0.010 \\
Thyroid & 0.017 & 0.051 & 0.028 & 0.036 & 0.119 & $7.49 \mathrm{E}-08$ & 0.043 & 0.010 \\
Esophagus & 0.008 & 0.025 & 0.012 & 0.015 & 0.048 & $1.42 \mathrm{E}-08$ & 0.020 & 0.004 \\
Skin & 0.003 & 0.008 & 0.004 & 0.005 & 0.018 & $1.14 \mathrm{E}-08$ & 0.006 & 0.001 \\
Other & 0.010 & 0.032 & 0.016 & 0.020 & 0.066 & $2.44 \mathrm{E}-08$ & 0.026 & 0.006 \\
Breast & 0.030 & 0.096 & 0.070 & 0.089 & 0.282 & $2.40 \mathrm{E}-07$ & 0.086 & 0.021 \\
\hline Total & 0.548 & 1.692 & 0.881 & 1.114 & 3.596 & $1.74 \mathrm{E}-06$ & 1.334 & 0.279 \\
\hline
\end{tabular}

Table J.16 Effective Dose Contribution by Organ for Adipose Female Healthcare Provider from the Reference Male Patient ( $\mu \mathrm{Sv} / \mathrm{hr}) / \mathrm{ALI}$

\begin{tabular}{|c|cccccccc|}
\hline Organ & ${ }^{\mathbf{6 0}} \mathbf{C o}(\mathbf{s})$ & ${ }^{\mathbf{6 0}} \mathbf{C o}(\mathbf{m})$ & ${ }^{\mathbf{1 9 2}} \mathbf{I r}(\mathbf{s})$ & ${ }^{\mathbf{1 9 2}} \mathbf{I r}(\mathbf{m})$ & ${ }^{\mathbf{1 9 2}} \mathbf{I r}(\mathbf{f})$ & ${ }^{\mathbf{2 4 1}} \mathbf{A m}$ & ${ }^{\mathbf{1 3 7}} \mathbf{C s}$ & ${ }^{\mathbf{1 3 1}} \mathbf{I}$ \\
\hline \hline Gonads & 0.053 & 0.167 & 0.091 & 0.105 & 0.237 & $9.27 \mathrm{E}-08$ & 0.070 & 0.024 \\
Stomach & 0.117 & 0.349 & 0.222 & 0.254 & 0.673 & $4.93 \mathrm{E}-07$ & 0.176 & 0.066 \\
Colon Wall & 0.110 & 0.342 & 0.186 & 0.217 & 0.554 & $2.84 \mathrm{E}-07$ & 0.166 & 0.057 \\
Bladder & 0.091 & 0.279 & 0.153 & 0.180 & 0.459 & $2.43 \mathrm{E}-07$ & 0.132 & 0.046 \\
Lungs & 0.039 & 0.118 & 0.070 & 0.085 & 0.196 & $1.72 \mathrm{E}-07$ & 0.056 & 0.022 \\
Bone & 0.050 & 0.156 & 0.099 & 0.119 & 0.288 & $3.82 \mathrm{E}-07$ & 0.075 & 0.029 \\
Liver & 0.021 & 0.065 & 0.040 & 0.049 & 0.099 & $1.07 \mathrm{E}-07$ & 0.030 & 0.012 \\
Thyroid & 0.020 & 0.062 & 0.040 & 0.049 & 0.121 & $1.35 \mathrm{E}-07$ & 0.029 & 0.012 \\
Esophagus & 0.012 & 0.039 & 0.019 & 0.023 & 0.062 & $2.99 \mathrm{E}-08$ & 0.017 & 0.006 \\
Skin & 0.004 & 0.014 & 0.008 & 0.010 & 0.024 & $2.40 \mathrm{E}-08$ & 0.007 & 0.002 \\
Other & 0.015 & 0.044 & 0.025 & 0.030 & 0.070 & $4.41 \mathrm{E}-08$ & 0.022 & 0.008 \\
Breast & 0.078 & 0.238 & 0.164 & 0.199 & 0.453 & $6.09 \mathrm{E}-07$ & 0.117 & 0.048 \\
\hline Total & 0.610 & 1.871 & 1.119 & 1.322 & 3.236 & $2.62 \mathrm{E}-06$ & 0.895 & 0.333 \\
\hline
\end{tabular}


Table J.17 Effective Dose Contribution by Organ for Adipose Female Healthcare Provider from the Reference Female Patient ( $\mu \mathrm{Sv} / \mathrm{hr})$ /ALI

\begin{tabular}{|c|cccccccc|}
\hline Organ & ${ }^{\mathbf{6 0}} \mathbf{C o}(\mathbf{s})$ & ${ }^{\mathbf{6 0}} \mathbf{C o}(\mathbf{m})$ & ${ }^{\mathbf{1 9 2}} \mathbf{I r}(\mathbf{s})$ & ${ }^{\mathbf{1 9 2}} \mathbf{I r}(\mathbf{m})$ & ${ }^{\mathbf{1 9 2}} \mathbf{I r}(\mathbf{f})$ & ${ }^{\mathbf{2 4 1}} \mathbf{A m}$ & ${ }^{\mathbf{1 3 7}} \mathbf{C s}$ & ${ }^{\mathbf{1 3 1}} \mathbf{I}$ \\
\hline \hline Gonads & 0.054 & 0.172 & 0.079 & 0.102 & 0.253 & $1.44 \mathrm{E}-07$ & 0.079 & 0.027 \\
Stomach & 0.125 & 0.373 & 0.224 & 0.283 & 0.738 & $5.75 \mathrm{E}-07$ & 0.168 & 0.067 \\
Colon Wall & 0.117 & 0.368 & 0.182 & 0.230 & 0.568 & $3.19 \mathrm{E}-07$ & 0.188 & 0.057 \\
Bladder & 0.095 & 0.296 & 0.152 & 0.191 & 0.456 & $2.45 \mathrm{E}-07$ & 0.155 & 0.044 \\
Lungs & 0.040 & 0.123 & 0.071 & 0.089 & 0.210 & $1.83 \mathrm{E}-07$ & 0.064 & 0.022 \\
Bone & 0.051 & 0.157 & 0.095 & 0.120 & 0.293 & $3.90 \mathrm{E}-07$ & 0.083 & 0.029 \\
Liver & 0.022 & 0.068 & 0.042 & 0.052 & 0.104 & $1.16 \mathrm{E}-07$ & 0.043 & 0.013 \\
Thyroid & 0.020 & 0.061 & 0.039 & 0.050 & 0.123 & $1.23 \mathrm{E}-07$ & 0.032 & 0.013 \\
Esophagus & 0.013 & 0.040 & 0.021 & 0.026 & 0.064 & $3.70 \mathrm{E}-08$ & 0.020 & 0.007 \\
Skin & 0.005 & 0.014 & 0.008 & 0.010 & 0.025 & $2.58 \mathrm{E}-08$ & 0.008 & 0.002 \\
Other & 0.016 & 0.047 & 0.025 & 0.032 & 0.077 & $4.83 \mathrm{E}-08$ & 0.023 & 0.008 \\
Breast & 0.080 & 0.245 & 0.165 & 0.207 & 0.483 & $6.52 \mathrm{E}-07$ & 0.136 & 0.050 \\
\hline Total & 0.636 & 1.964 & 1.102 & 1.393 & 3.394 & $2.86 \mathrm{E}-06$ & 0.999 & 0.339 \\
\hline
\end{tabular}

Table J.18 Effective Dose Contribution by Organ for Adipose Female Healthcare Provider from the Adipose Male Patient $(\mu \mathrm{Sv} / \mathrm{hr}) / \mathrm{ALI}$

\begin{tabular}{|c|cccccccc|}
\hline Organ & ${ }^{\mathbf{6 0}} \mathbf{C o}(\mathbf{s})$ & ${ }^{\mathbf{6 0}} \mathbf{C o}(\mathbf{m})$ & ${ }^{\mathbf{1 9 2}} \mathbf{I r}(\mathbf{s})$ & ${ }^{\mathbf{1 9 2}} \mathbf{I r}(\mathbf{m})$ & ${ }^{\mathbf{1 9 2}} \mathbf{I r}(\mathbf{f})$ & ${ }^{{ }^{\mathbf{4 4 1}} \mathbf{A m}}$ & ${ }^{\mathbf{1 3 7}} \mathbf{C s}$ & ${ }^{\mathbf{1 3 1}} \mathbf{I}$ \\
\hline \hline Gonads & 0.049 & 0.153 & 0.070 & 0.090 & 0.247 & $7.74 \mathrm{E}-08$ & 0.078 & 0.022 \\
Stomach & 0.109 & 0.329 & 0.182 & 0.234 & 0.713 & $3.94 \mathrm{E}-07$ & 0.181 & 0.059 \\
Colon Wall & 0.103 & 0.321 & 0.157 & 0.200 & 0.562 & $2.20 \mathrm{E}-07$ & 0.166 & 0.051 \\
Bladder & 0.084 & 0.263 & 0.129 & 0.163 & 0.447 & $1.79 \mathrm{E}-07$ & 0.129 & 0.040 \\
Lungs & 0.034 & 0.105 & 0.057 & 0.072 & 0.193 & $1.22 \mathrm{E}-07$ & 0.055 & 0.019 \\
Bone & 0.046 & 0.142 & 0.083 & 0.105 & 0.282 & $2.72 \mathrm{E}-07$ & 0.073 & 0.026 \\
Liver & 0.019 & 0.061 & 0.035 & 0.044 & 0.104 & $8.30 \mathrm{E}-08$ & 0.031 & 0.011 \\
Thyroid & 0.018 & 0.053 & 0.028 & 0.036 & 0.116 & $7.42 \mathrm{E}-08$ & 0.029 & 0.011 \\
Esophagus & 0.011 & 0.034 & 0.016 & 0.020 & 0.058 & $2.38 \mathrm{E}-08$ & 0.017 & 0.006 \\
Skin & 0.004 & 0.013 & 0.007 & 0.009 & 0.024 & $1.81 \mathrm{E}-08$ & 0.007 & 0.002 \\
Other & 0.014 & 0.041 & 0.021 & 0.026 & 0.071 & $3.25 \mathrm{E}-08$ & 0.021 & 0.007 \\
Breast & 0.068 & 0.212 & 0.132 & 0.168 & 0.453 & $4.24 \mathrm{E}-07$ & 0.117 & 0.042 \\
\hline Total & 0.559 & 1.728 & 0.918 & 1.167 & 3.270 & $1.92 \mathrm{E}-06$ & 0.904 & 0.297 \\
\hline
\end{tabular}


Table J.19 Effective Dose Contribution by Organ for Adipose Female Healthcare Provider from the Adipose Female Patient ( $\mu \mathrm{Sv} / \mathrm{hr}) / \mathrm{ALI}$

\begin{tabular}{|c|cccccccc|}
\hline Organ & ${ }^{\mathbf{6}} \mathbf{C o}(\mathbf{s})$ & ${ }^{\mathbf{6}} \mathbf{C o}(\mathbf{m})$ & ${ }^{\mathbf{1 9 2}} \mathbf{I r}(\mathbf{s})$ & ${ }^{\mathbf{1 9 2}} \mathbf{I r}(\mathbf{m})$ & ${ }^{\mathbf{1 9 2}} \mathbf{I r}(\mathbf{f})$ & ${ }^{\mathbf{2 4 1}} \mathbf{A m}$ & ${ }^{\mathbf{1 3 7}} \mathbf{C s}$ & ${ }^{\mathbf{1 3 1}} \mathbf{I}$ \\
\hline \hline Gonads & 0.037 & 0.156 & 0.079 & 0.099 & 0.318 & $1.36 \mathrm{E}-07$ & 0.073 & 0.024 \\
Stomach & 0.086 & 0.358 & 0.211 & 0.269 & 0.798 & $5.06 \mathrm{E}-07$ & 0.195 & 0.067 \\
Colon Wall & 0.081 & 0.352 & 0.171 & 0.217 & 0.732 & $2.57 \mathrm{E}-07$ & 0.170 & 0.055 \\
Bladder & 0.066 & 0.287 & 0.141 & 0.177 & 0.600 & $2.12 \mathrm{E}-07$ & 0.130 & 0.042 \\
Lungs & 0.026 & 0.113 & 0.063 & 0.080 & 0.250 & $1.46 \mathrm{E}-07$ & 0.057 & 0.021 \\
Bone & 0.034 & 0.149 & 0.088 & 0.111 & 0.353 & $3.11 \mathrm{E}-07$ & 0.075 & 0.028 \\
Liver & 0.015 & 0.066 & 0.039 & 0.049 & 0.166 & $9.90 \mathrm{E}-08$ & 0.032 & 0.012 \\
Thyroid & 0.012 & 0.052 & 0.032 & 0.040 & 0.121 & $9.41 \mathrm{E}-08$ & 0.030 & 0.012 \\
Esophagus & 0.009 & 0.037 & 0.018 & 0.022 & 0.073 & $2.69 \mathrm{E}-08$ & 0.019 & 0.006 \\
Skin & 0.003 & 0.014 & 0.008 & 0.010 & 0.031 & $2.16 \mathrm{E}-08$ & 0.007 & 0.002 \\
Other & 0.010 & 0.046 & 0.022 & 0.029 & 0.091 & $4.01 \mathrm{E}-08$ & 0.022 & 0.008 \\
Breast & 0.053 & 0.226 & 0.147 & 0.186 & 0.589 & $5.09 \mathrm{E}-07$ & 0.122 & 0.046 \\
\hline Total & 0.433 & 1.854 & 1.019 & 1.289 & 4.123 & $2.36 \mathrm{E}-06$ & 0.931 & 0.322 \\
\hline
\end{tabular}

Table J.20 Effective Dose Contribution by Organ for Adipose Female Healthcare Provider from the Postmenopausal Adipose Female Patient ( $\mu \mathrm{Sv} / \mathrm{hr}) / \mathrm{ALI}$

\begin{tabular}{|c|cccccccc|}
\hline Organ & ${ }^{\mathbf{6 0}} \mathbf{C o}(\mathbf{s})$ & ${ }^{\mathbf{6 0}} \mathbf{C o}(\mathbf{m})$ & ${ }^{\mathbf{1 9 2}} \mathbf{I r}(\mathbf{s})$ & ${ }^{\mathbf{1 9 2}} \mathbf{I r}(\mathbf{m})$ & ${ }^{\mathbf{1 9 2}} \mathbf{I r}(\mathbf{f})$ & ${ }^{\mathbf{2 4 1}} \mathbf{A m}$ & ${ }^{\mathbf{1 3 7}} \mathbf{C s}$ & ${ }^{\mathbf{1 3 1}} \mathbf{I}$ \\
\hline \hline Gonads & 0.037 & 0.162 & 0.075 & 0.092 & 0.235 & $1.07 \mathrm{E}-07$ & 0.125 & 0.023 \\
Stomach & 0.083 & 0.345 & 0.199 & 0.254 & 0.736 & $4.47 \mathrm{E}-07$ & 0.287 & 0.062 \\
Colon Wall & 0.078 & 0.340 & 0.163 & 0.208 & 0.563 & $2.41 \mathrm{E}-07$ & 0.277 & 0.053 \\
Bladder & 0.062 & 0.272 & 0.136 & 0.172 & 0.437 & $2.02 \mathrm{E}-07$ & 0.212 & 0.041 \\
Lungs & 0.025 & 0.110 & 0.060 & 0.075 & 0.197 & $1.31 \mathrm{E}-07$ & 0.086 & 0.020 \\
Bone & 0.033 & 0.145 & 0.085 & 0.107 & 0.282 & $2.83 \mathrm{E}-07$ & 0.116 & 0.027 \\
Liver & 0.014 & 0.063 & 0.037 & 0.046 & 0.102 & $8.80 \mathrm{E}-08$ & 0.047 & 0.011 \\
Thyroid & 0.012 & 0.052 & 0.032 & 0.040 & 0.113 & $8.50 \mathrm{E}-08$ & 0.046 & 0.011 \\
Esophagus & 0.008 & 0.034 & 0.017 & 0.022 & 0.057 & $2.07 \mathrm{E}-08$ & 0.027 & 0.006 \\
Skin & 0.003 & 0.013 & 0.007 & 0.009 & 0.024 & $1.93 \mathrm{E}-08$ & 0.010 & 0.002 \\
Other & 0.010 & 0.045 & 0.021 & 0.026 & 0.075 & $3.55 \mathrm{E}-08$ & 0.034 & 0.007 \\
Breast & 0.051 & 0.220 & 0.140 & 0.177 & 0.455 & $4.59 \mathrm{E}-07$ & 0.175 & 0.044 \\
\hline Total & 0.418 & 1.799 & 0.972 & 1.230 & 3.275 & $2.12 \mathrm{E}-06$ & 1.442 & 0.306 \\
\hline
\end{tabular}


Table J.21 Effective Dose Contribution by Organ for Postmenopausal Adipose Female Healthcare Provider from the Reference Male Patient ( $\mu \mathrm{Sv} / \mathrm{hr}) / \mathrm{ALI}$

\begin{tabular}{|c|cccccccc|}
\hline Organ & ${ }^{\mathbf{6 0}} \mathbf{C o}(\mathbf{s})$ & ${ }^{\mathbf{6 0}} \mathbf{C o}(\mathbf{m})$ & ${ }^{\mathbf{1 9 2}} \mathbf{I r}(\mathbf{s})$ & ${ }^{\mathbf{1 9 2}} \mathbf{I r}(\mathbf{m})$ & ${ }^{\mathbf{1 9 2}} \mathbf{I r}(\mathbf{f})$ & ${ }^{\mathbf{2 4 1}} \mathbf{A m}$ & ${ }^{\mathbf{1 3 7}} \mathbf{C s}$ & ${ }^{\mathbf{1 3 1}} \mathbf{I}$ \\
\hline \hline Gonads & 0.073 & 0.303 & 0.156 & 0.175 & 0.448 & $1.84 \mathrm{E}-07$ & 0.145 & 0.049 \\
Stomach & 0.076 & 0.318 & 0.197 & 0.223 & 0.613 & $4.25 \mathrm{E}-07$ & 0.156 & 0.059 \\
Colon Wall & 0.073 & 0.316 & 0.165 & 0.193 & 0.484 & $2.20 \mathrm{E}-07$ & 0.149 & 0.052 \\
Bladder & 0.059 & 0.254 & 0.134 & 0.156 & 0.398 & $1.87 \mathrm{E}-07$ & 0.116 & 0.040 \\
Lungs & 0.027 & 0.115 & 0.067 & 0.081 & 0.189 & $1.55 \mathrm{E}-07$ & 0.053 & 0.020 \\
Bone & 0.035 & 0.151 & 0.097 & 0.116 & 0.281 & $3.50 \mathrm{E}-07$ & 0.073 & 0.029 \\
Liver & 0.014 & 0.063 & 0.037 & 0.045 & 0.089 & $9.28 \mathrm{E}-08$ & 0.028 & 0.011 \\
Thyroid & 0.020 & 0.086 & 0.053 & 0.066 & 0.165 & $1.72 \mathrm{E}-07$ & 0.042 & 0.017 \\
Esophagus & 0.009 & 0.039 & 0.019 & 0.023 & 0.058 & $2.61 \mathrm{E}-08$ & 0.016 & 0.006 \\
Skin & 0.003 & 0.013 & 0.008 & 0.009 & 0.022 & $2.18 \mathrm{E}-08$ & 0.006 & 0.002 \\
Other & 0.010 & 0.042 & 0.024 & 0.028 & 0.066 & $3.82 \mathrm{E}-08$ & 0.021 & 0.007 \\
Breast & 0.052 & 0.221 & 0.154 & 0.187 & 0.423 & $5.75 \mathrm{E}-07$ & 0.109 & 0.045 \\
\hline Total & 0.452 & 1.921 & 1.110 & 1.302 & 3.237 & $2.45 \mathrm{E}-06$ & 0.914 & 0.337 \\
\hline
\end{tabular}

Table J.22 Effective Dose Contribution by Organ for Postmenopausal Adipose Female Healthcare Provider from the Reference Female Patient $(\mu \mathrm{Sv} / \mathrm{hr}) / \mathrm{ALI}$

\begin{tabular}{|l|rrrrrrrr|}
\hline Organ & ${ }^{\mathbf{6 0}} \mathbf{C o}(\mathbf{s})$ & ${ }^{\mathbf{6 0}} \mathbf{C o}(\mathbf{m})$ & ${ }^{\mathbf{1 9 2}} \mathbf{I r}(\mathbf{s})$ & ${ }^{\mathbf{1 9 2}} \mathbf{I r}(\mathbf{m})$ & ${ }^{\mathbf{1 9 2}} \mathbf{I r}(\mathbf{f})$ & ${ }^{\mathbf{2 4 1}} \mathbf{A m}$ & ${ }^{\mathbf{1 3 7}} \mathbf{C s}$ & ${ }^{\mathbf{1 3 1}} \mathbf{I}$ \\
\hline \hline Gonads & 0.116 & 0.353 & 0.150 & 0.191 & 0.472 & $1.64 \mathrm{E}-07$ & 0.169 & 0.041 \\
Stomach & 0.115 & 0.345 & 0.196 & 0.248 & 0.667 & $4.93 \mathrm{E}-07$ & 0.146 & 0.060 \\
Colon Wall & 0.107 & 0.335 & 0.162 & 0.204 & 0.506 & $2.51 \mathrm{E}-07$ & 0.168 & 0.050 \\
Bladder & 0.085 & 0.267 & 0.128 & 0.161 & 0.394 & $1.86 \mathrm{E}-07$ & 0.136 & 0.038 \\
Lungs & 0.038 & 0.119 & 0.067 & 0.085 & 0.200 & $1.67 \mathrm{E}-07$ & 0.062 & 0.022 \\
Bone & 0.049 & 0.153 & 0.093 & 0.117 & 0.285 & $3.55 \mathrm{E}-07$ & 0.081 & 0.028 \\
Liver & 0.021 & 0.065 & 0.038 & 0.048 & 0.094 & $1.00 \mathrm{E}-07$ & 0.041 & 0.012 \\
Thyroid & 0.029 & 0.086 & 0.054 & 0.067 & 0.167 & $1.69 \mathrm{E}-07$ & 0.045 & 0.018 \\
Esophagus & 0.012 & 0.040 & 0.019 & 0.024 & 0.062 & $3.15 \mathrm{E}-08$ & 0.018 & 0.006 \\
Skin & 0.004 & 0.013 & 0.007 & 0.009 & 0.022 & $2.36 \mathrm{E}-08$ & 0.007 & 0.002 \\
Other & 0.014 & 0.043 & 0.022 & 0.029 & 0.069 & $3.99 \mathrm{E}-08$ & 0.022 & 0.008 \\
Breast & 0.075 & 0.229 & 0.154 & 0.194 & 0.451 & $6.20 \mathrm{E}-07$ & 0.127 & 0.046 \\
\hline Total & 0.667 & 2.048 & 1.091 & 1.377 & 3.390 & $2.60 \mathrm{E}-06$ & 1.022 & 0.333 \\
\hline
\end{tabular}


Table J.23 Effective Dose Contribution by Organ for Postmenopausal Adipose Female Healthcare Provider from the Adipose Male Patient ( $\mu \mathrm{Sv} / \mathrm{hr}) / A L I$

\begin{tabular}{|c|cccccccc|}
\hline Organ & ${ }^{\mathbf{6 0}} \mathbf{C o}(\mathbf{s})$ & ${ }^{\mathbf{6 0}} \mathbf{C o}(\mathbf{m})$ & ${ }^{\mathbf{1 9 2}} \mathbf{I r}(\mathbf{s})$ & ${ }^{\mathbf{1 9 2}} \mathbf{I r}(\mathbf{m})$ & ${ }^{\mathbf{1 9 2}} \mathbf{I r}(\mathbf{f})$ & ${ }^{\mathbf{2 4 1}} \mathbf{A m}$ & ${ }^{\mathbf{1 3 7}} \mathbf{C s}$ & ${ }^{\mathbf{1 3 1}} \mathbf{I}$ \\
\hline \hline Gonads & 0.094 & 0.303 & 0.120 & 0.155 & 0.456 & $1.40 \mathrm{E}-07$ & 0.135 & 0.044 \\
Stomach & 0.099 & 0.296 & 0.162 & 0.208 & 0.644 & $3.20 \mathrm{E}-07$ & 0.161 & 0.053 \\
Colon Wall & 0.093 & 0.296 & 0.138 & 0.175 & 0.494 & $1.72 \mathrm{E}-07$ & 0.148 & 0.046 \\
Bladder & 0.075 & 0.235 & 0.111 & 0.141 & 0.387 & $1.43 \mathrm{E}-07$ & 0.110 & 0.034 \\
Lungs & 0.033 & 0.102 & 0.054 & 0.069 & 0.185 & $1.10 \mathrm{E}-07$ & 0.053 & 0.018 \\
Bone & 0.044 & 0.137 & 0.080 & 0.102 & 0.273 & $2.47 \mathrm{E}-07$ & 0.071 & 0.026 \\
Liver & 0.018 & 0.059 & 0.033 & 0.041 & 0.095 & $7.15 \mathrm{E}-08$ & 0.029 & 0.010 \\
Thyroid & 0.025 & 0.075 & 0.042 & 0.052 & 0.159 & $9.83 \mathrm{E}-08$ & 0.042 & 0.016 \\
Esophagus & 0.010 & 0.031 & 0.016 & 0.020 & 0.056 & $1.95 \mathrm{E}-08$ & 0.016 & 0.005 \\
Skin & 0.004 & 0.011 & 0.006 & 0.008 & 0.022 & $1.64 \mathrm{E}-08$ & 0.006 & 0.002 \\
Other & 0.013 & 0.040 & 0.019 & 0.024 & 0.068 & $2.67 \mathrm{E}-08$ & 0.019 & 0.012 \\
Breast & 0.064 & 0.198 & 0.124 & 0.157 & 0.425 & $3.97 \mathrm{E}-07$ & 0.109 & 0.040 \\
\hline Total & 0.571 & 1.784 & 0.905 & 1.151 & 3.263 & $1.76 \mathrm{E}-06$ & 0.899 & 0.306 \\
\hline
\end{tabular}

Table J.24 Effective Dose Contribution by Organ for Postmenopausal Adipose Female Healthcare Provider from the Adipose Female Patient $(\mu \mathrm{Sv} / \mathrm{hr}) / \mathrm{ALI}$

\begin{tabular}{|c|cccccccc|}
\hline Organ & ${ }^{\mathbf{6 0}} \mathbf{C o}(\mathbf{s})$ & ${ }^{\mathbf{6 0}} \mathbf{C o}(\mathbf{m})$ & ${ }^{\mathbf{1 9 2}} \mathbf{I r}(\mathbf{s})$ & ${ }^{\mathbf{1 9 2}} \mathbf{I r}(\mathbf{m})$ & ${ }^{\mathbf{1 9 2}} \mathbf{I r}(\mathbf{f})$ & ${ }^{\mathbf{2 4 1}} \mathbf{A m}$ & ${ }^{\mathbf{1 3 7}} \mathbf{C s}$ & ${ }^{\mathbf{1 3 1}} \mathbf{I}$ \\
\hline \hline Gonads & 0.102 & 0.325 & 0.139 & 0.173 & 0.585 & $1.55 \mathrm{E}-07$ & 0.149 & 0.047 \\
Stomach & 0.110 & 0.331 & 0.185 & 0.236 & 0.689 & $4.10 \mathrm{E}-07$ & 0.176 & 0.060 \\
Colon Wall & 0.101 & 0.316 & 0.150 & 0.190 & 0.645 & $1.99 \mathrm{E}-07$ & 0.152 & 0.050 \\
Bladder & 0.082 & 0.256 & 0.121 & 0.152 & 0.513 & $1.55 \mathrm{E}-07$ & 0.118 & 0.037 \\
Lungs & 0.036 & 0.110 & 0.061 & 0.077 & 0.241 & $1.37 \mathrm{E}-07$ & 0.055 & 0.020 \\
Bone & 0.046 & 0.145 & 0.085 & 0.108 & 0.343 & $2.82 \mathrm{E}-07$ & 0.073 & 0.027 \\
Liver & 0.020 & 0.062 & 0.036 & 0.045 & 0.153 & $8.43 \mathrm{E}-08$ & 0.030 & 0.011 \\
Thyroid & 0.025 & 0.078 & 0.043 & 0.054 & 0.167 & $1.17 \mathrm{E}-07$ & 0.042 & 0.016 \\
Esophagus & 0.012 & 0.036 & 0.016 & 0.020 & 0.064 & $2.83 \mathrm{E}-08$ & 0.016 & 0.006 \\
Skin & 0.004 & 0.012 & 0.007 & 0.009 & 0.029 & $1.99 \mathrm{E}-08$ & 0.006 & 0.002 \\
Other & 0.014 & 0.043 & 0.021 & 0.027 & 0.088 & $3.44 \mathrm{E}-08$ & 0.020 & 0.007 \\
Breast & 0.068 & 0.211 & 0.138 & 0.174 & 0.552 & $4.82 \mathrm{E}-07$ & 0.114 & 0.043 \\
\hline Total & 0.620 & 1.926 & 1.002 & 1.265 & 4.067 & $2.10 \mathrm{E}-06$ & 0.951 & 0.327 \\
\hline
\end{tabular}


Table J.25 Effective Dose Contribution by Organ for Postmenopausal Adipose Female Healthcare Provider from the Postmenopausal Adipose Female Patient $(\mu \mathrm{Sv} / \mathrm{hr}) / \mathrm{ALI}$

\begin{tabular}{|c|cccccccc|}
\hline Organ & ${ }^{\mathbf{6 0}} \mathbf{C o}(\mathbf{s})$ & ${ }^{\mathbf{6 0}} \mathbf{C o}(\mathbf{m})$ & ${ }^{\mathbf{1 9 2}} \mathbf{I r}(\mathbf{s})$ & ${ }^{\mathbf{1 9 2}} \mathbf{I r}(\mathbf{m})$ & ${ }^{\mathbf{1 9 2}} \mathbf{I r}(\mathbf{f})$ & ${ }^{\mathbf{2 4 1}} \mathbf{A m}$ & ${ }^{\mathbf{1 3 7}} \mathbf{C s}$ & ${ }^{\mathbf{1 3 1}} \mathbf{I}$ \\
\hline \hline Gonads & 0.101 & 0.315 & 0.136 & 0.173 & 0.417 & $1.25 \mathrm{E}-07$ & 0.243 & 0.041 \\
Stomach & 0.105 & 0.316 & 0.174 & 0.221 & 0.663 & $3.60 \mathrm{E}-07$ & 0.259 & 0.057 \\
Colon Wall & 0.098 & 0.308 & 0.143 & 0.180 & 0.501 & $1.85 \mathrm{E}-07$ & 0.249 & 0.047 \\
Bladder & 0.078 & 0.244 & 0.116 & 0.145 & 0.366 & $1.52 \mathrm{E}-07$ & 0.186 & 0.035 \\
Lungs & 0.034 & 0.107 & 0.057 & 0.072 & 0.188 & $1.17 \mathrm{E}-07$ & 0.084 & 0.019 \\
Bone & 0.045 & 0.140 & 0.082 & 0.104 & 0.273 & $2.55 \mathrm{E}-07$ & 0.112 & 0.026 \\
Liver & 0.019 & 0.060 & 0.034 & 0.043 & 0.093 & $7.50 \mathrm{E}-08$ & 0.045 & 0.011 \\
Thyroid & 0.024 & 0.074 & 0.042 & 0.053 & 0.150 & $1.10 \mathrm{E}-07$ & 0.064 & 0.015 \\
Esophagus & 0.011 & 0.035 & 0.016 & 0.020 & 0.059 & $2.12 \mathrm{E}-08$ & 0.026 & 0.005 \\
Skin & 0.004 & 0.012 & 0.007 & 0.008 & 0.022 & $1.78 \mathrm{E}-08$ & 0.009 & 0.002 \\
Other & 0.013 & 0.040 & 0.019 & 0.024 & 0.067 & $2.87 \mathrm{E}-08$ & 0.031 & 0.006 \\
Breast & 0.066 & 0.204 & 0.131 & 0.166 & 0.425 & $4.31 \mathrm{E}-07$ & 0.162 & 0.041 \\
\hline \hline Total & 0.599 & 1.855 & 0.955 & 1.211 & 3.224 & $1.88 \mathrm{E}-06$ & 1.470 & 0.305 \\
\hline
\end{tabular}




\section{APPENDIX K}

\section{ABSORB DOSE TO PATIENT}

Table K.1 Absorbed Dose to Organs for Reference Male Patient for $37 \mathrm{GBq} / \mathrm{m}^{2}$ Surface Contamination $(\mathrm{mGy} / \mathrm{hr})$

\begin{tabular}{|l|c|c|c|c|c|}
\hline Organ & ${ }^{\mathbf{6 0}} \mathbf{C o}$ & ${ }^{192} \mathbf{I r}$ & ${ }^{\mathbf{2 4 1}} \mathbf{A m}$ & ${ }^{\mathbf{1 3 7}} \mathbf{C s}$ & ${ }^{\mathbf{1 3 1}_{\mathbf{I}}}$ \\
\hline \hline Gonads & $1.55 \mathrm{E}+02$ & $6.13 \mathrm{E}+01$ & $2.93 \mathrm{E}+00$ & $3.95 \mathrm{E}+01$ & $2.30 \mathrm{E}+01$ \\
\hline Stomach & $2.61 \mathrm{E}+02$ & $9.61 \mathrm{E}+01$ & $2.26 \mathrm{E}+00$ & $6.29 \mathrm{E}+01$ & $3.61 \mathrm{E}+01$ \\
\hline Colon Wall & $3.36 \mathrm{E}+02$ & $1.25 \mathrm{E}+02$ & $2.77 \mathrm{E}+00$ & $8.15 \mathrm{E}+01$ & $4.69 \mathrm{E}+01$ \\
\hline Bladder & $4.87 \mathrm{E}+02$ & $1.84 \mathrm{E}+02$ & $4.50 \mathrm{E}+00$ & $1.19 \mathrm{E}+02$ & $6.89 \mathrm{E}+01$ \\
\hline Lungs & $1.08 \mathrm{E}+02$ & $4.13 \mathrm{E}+01$ & $1.06 \mathrm{E}+00$ & $2.67 \mathrm{E}+01$ & $1.55 \mathrm{E}+01$ \\
\hline Bone & $1.83 \mathrm{E}+02$ & $7.56 \mathrm{E}+01$ & $5.14 \mathrm{E}+00$ & $4.58 \mathrm{E}+01$ & $2.75 \mathrm{E}+01$ \\
\hline Liver & $9.98 \mathrm{E}+01$ & $3.70 \mathrm{E}+01$ & $8.67 \mathrm{E}-01$ & $2.42 \mathrm{E}+01$ & $1.39 \mathrm{E}+01$ \\
\hline Thyroid & $2.02 \mathrm{E}+02$ & $7.76 \mathrm{E}+01$ & $2.36 \mathrm{E}+00$ & $5.03 \mathrm{E}+01$ & $2.92 \mathrm{E}+01$ \\
\hline Esophagus & $9.38 \mathrm{E}+01$ & $3.52 \mathrm{E}+01$ & $6.88 \mathrm{E}-01$ & $2.30 \mathrm{E}+01$ & $1.33 \mathrm{E}+01$ \\
\hline Skin & $1.33 \mathrm{E}+02$ & $6.53 \mathrm{E}+01$ & $1.07 \mathrm{E}+01$ & $4.00 \mathrm{E}+01$ & $2.46 \mathrm{E}+01$ \\
\hline Other & $1.20 \mathrm{E}+02$ & $4.58 \mathrm{E}+01$ & $1.04 \mathrm{E}+00$ & $2.98 \mathrm{E}+01$ & $1.71 \mathrm{E}+01$ \\
\hline Total & $2.18 \mathrm{E}+03$ & $8.44 \mathrm{E}+02$ & $3.43 \mathrm{E}+01$ & $5.42 \mathrm{E}+02$ & $3.16 \mathrm{E}+02$ \\
\hline
\end{tabular}

Table K.2 Absorbed Dose to Organs for Reference Female Patient for $37 \mathrm{GBq} / \mathrm{m}^{2}$ Surface Contamination $(\mathrm{mGy} / \mathrm{hr})$

\begin{tabular}{|l|c|c|c|c|c|}
\hline Organ & ${ }^{\mathbf{6 0}} \mathbf{C o}$ & ${ }^{\mathbf{1 9 2}} \mathbf{I r}$ & ${ }^{\mathbf{2 4 1}} \mathbf{A m}$ & ${ }^{\mathbf{1 3 7}} \mathbf{C s}$ & ${ }^{\mathbf{1 3 1}} \mathbf{I}$ \\
\hline \hline Gonads & $7.19 \mathrm{E}+01$ & $2.67 \mathrm{E}+01$ & $5.41 \mathrm{E}-01$ & $1.74 \mathrm{E}+01$ & $1.01 \mathrm{E}+01$ \\
\hline Stomach & $2.05 \mathrm{E}+02$ & $7.63 \mathrm{E}+01$ & $1.87 \mathrm{E}+00$ & $4.98 \mathrm{E}+01$ & $2.87 \mathrm{E}+01$ \\
\hline Colon Wall & $2.57 \mathrm{E}+02$ & $9.57 \mathrm{E}+01$ & $2.22 \mathrm{E}+00$ & $6.20 \mathrm{E}+01$ & $3.58 \mathrm{E}+01$ \\
\hline Bladder & $4.43 \mathrm{E}+02$ & $1.67 \mathrm{E}+02$ & $4.17 \mathrm{E}+00$ & $1.08 \mathrm{E}+02$ & $6.26 \mathrm{E}+01$ \\
\hline Lungs & $9.45 \mathrm{E}+01$ & $3.64 \mathrm{E}+01$ & $9.49 \mathrm{E}-01$ & $2.33 \mathrm{E}+01$ & $1.36 \mathrm{E}+01$ \\
\hline Bone & $1.88 \mathrm{E}+02$ & $7.85 \mathrm{E}+01$ & $5.22 \mathrm{E}+00$ & $4.75 \mathrm{E}+01$ & $2.85 \mathrm{E}+01$ \\
\hline Liver & $8.81 \mathrm{E}+01$ & $3.30 \mathrm{E}+01$ & $7.89 \mathrm{E}-01$ & $2.15 \mathrm{E}+01$ & $1.24 \mathrm{E}+01$ \\
\hline Thyroid & $1.41 \mathrm{E}+02$ & $5.44 \mathrm{E}+01$ & $1.73 \mathrm{E}+00$ & $3.55 \mathrm{E}+01$ & $2.05 \mathrm{E}+01$ \\
\hline Esophagus & $9.96 \mathrm{E}+01$ & $3.81 \mathrm{E}+01$ & $7.62 \mathrm{E}-01$ & $2.45 \mathrm{E}+01$ & $1.43 \mathrm{E}+01$ \\
\hline Skin & $1.80 \mathrm{E}+02$ & $8.78 \mathrm{E}+01$ & $1.40 \mathrm{E}+01$ & $5.38 \mathrm{E}+01$ & $3.31 \mathrm{E}+01$ \\
\hline Other & $1.00 \mathrm{E}+02$ & $3.81 \mathrm{E}+01$ & $8.66 \mathrm{E}-01$ & $2.47 \mathrm{E}+01$ & $1.42 \mathrm{E}+01$ \\
\hline Breasts & $3.21 \mathrm{E}+02$ & $1.27 \mathrm{E}+02$ & $7.37 \mathrm{E}+00$ & $8.15 \mathrm{E}+01$ & $4.81 \mathrm{E}+01$ \\
\hline Total & $2.19 \mathrm{E}+03$ & $8.59 \mathrm{E}+02$ & $4.05 \mathrm{E}+01$ & $5.49 \mathrm{E}+02$ & $3.22 \mathrm{E}+02$ \\
\hline
\end{tabular}


Table K.3 Absorbed Dose to Organs for Adipose Male Patient for $37 \mathrm{GBq} / \mathrm{m}^{2}$ Surface Contamination $(\mathrm{mGy} / \mathrm{hr})$

\begin{tabular}{|l|c|c|c|c|c|}
\hline Organ & ${ }^{\mathbf{6 0}} \mathbf{C o}$ & ${ }^{\mathbf{1 9 2}} \mathbf{I r}$ & ${ }^{\mathbf{2 4 1}} \mathbf{A m}$ & ${ }^{\mathbf{1 3 7}} \mathbf{C s}$ & ${ }^{\mathbf{1 3 1}} \mathbf{I}$ \\
\hline \hline Gonads & $2.21 \mathrm{E}+02$ & $8.94 \mathrm{E}+01$ & $4.47 \mathrm{E}+00$ & $5.64 \mathrm{E}+01$ & $3.35 \mathrm{E}+01$ \\
\hline Stomach & $2.00 \mathrm{E}+02$ & $7.47 \mathrm{E}+01$ & $1.62 \mathrm{E}+00$ & $4.82 \mathrm{E}+01$ & $2.79 \mathrm{E}+01$ \\
\hline Colon & $2.76 \mathrm{E}+02$ & $1.01 \mathrm{E}+02$ & $1.99 \mathrm{E}+00$ & $6.55 \mathrm{E}+01$ & $3.77 \mathrm{E}+01$ \\
\hline Bladder & $4.08 \mathrm{E}+02$ & $1.53 \mathrm{E}+02$ & $3.13 \mathrm{E}+00$ & $9.79 \mathrm{E}+01$ & $5.69 \mathrm{E}+01$ \\
\hline Lungs & $9.00 \mathrm{E}+01$ & $3.48 \mathrm{E}+01$ & $8.33 \mathrm{E}-01$ & $2.22 \mathrm{E}+01$ & $1.30 \mathrm{E}+01$ \\
\hline Bone & $2.14 \mathrm{E}+02$ & $9.14 \mathrm{E}+01$ & $4.98 \mathrm{E}+00$ & $5.39 \mathrm{E}+01$ & $3.28 \mathrm{E}+01$ \\
\hline Liver & $7.50 \mathrm{E}+01$ & $2.78 \mathrm{E}+01$ & $5.98 \mathrm{E}-01$ & $1.80 \mathrm{E}+01$ & $1.04 \mathrm{E}+01$ \\
\hline Thyroid & $2.27 \mathrm{E}+02$ & $8.97 \mathrm{E}+01$ & $2.79 \mathrm{E}+00$ & $5.74 \mathrm{E}+01$ & $3.35 \mathrm{E}+01$ \\
\hline Esophagus & $8.88 \mathrm{E}+01$ & $3.36 \mathrm{E}+01$ & $6.51 \mathrm{E}-01$ & $2.16 \mathrm{E}+01$ & $1.25 \mathrm{E}+01$ \\
\hline Skin & $1.76 \mathrm{E}+02$ & $8.42 \mathrm{E}+01$ & $1.32 \mathrm{E}+01$ & $5.18 \mathrm{E}+01$ & $3.17 \mathrm{E}+01$ \\
\hline Other & $1.13 \mathrm{E}+02$ & $4.26 \mathrm{E}+01$ & $1.03 \mathrm{E}+00$ & $2.76 \mathrm{E}+01$ & $1.60 \mathrm{E}+01$ \\
\hline Breasts & $2.42 \mathrm{E}+02$ & $9.65 \mathrm{E}+01$ & $6.56 \mathrm{E}+00$ & $6.23 \mathrm{E}+01$ & $3.66 \mathrm{E}+01$ \\
\hline Total & $2.33 \mathrm{E}+03$ & $9.19 \mathrm{E}+02$ & $4.19 \mathrm{E}+01$ & $5.83 \mathrm{E}+02$ & $3.43 \mathrm{E}+02$ \\
\hline
\end{tabular}

Table K.4 Absorbed Dose to Organs for Adipose Female Patient for 37 GBq $/ \mathrm{m}^{2}$ Surface Contamination $(\mathrm{mGy} / \mathrm{hr})$

\begin{tabular}{|l|c|c|c|c|c|}
\hline Organ & ${ }^{\mathbf{6 0}} \mathbf{C o}$ & ${ }^{192} \mathbf{I r}$ & ${ }^{\mathbf{2 4 1}} \mathbf{A m}$ & ${ }^{\mathbf{1 3 7}} \mathbf{C s}$ & ${ }^{\mathbf{1 3 1}} \mathbf{I}$ \\
\hline \hline Gonads & $7.08 \mathrm{E}+04$ & $2.62 \mathrm{E}+04$ & $4.71 \mathrm{E}+02$ & $1.68 \mathrm{E}+04$ & $9.80 \mathrm{E}+03$ \\
\hline Stomach & $2.09 \mathrm{E}+05$ & $7.88 \mathrm{E}+04$ & $1.84 \mathrm{E}+03$ & $5.09 \mathrm{E}+04$ & $2.95 \mathrm{E}+04$ \\
\hline Colon Wall & $2.47 \mathrm{E}+05$ & $9.19 \mathrm{E}+04$ & $1.96 \mathrm{E}+03$ & $5.93 \mathrm{E}+04$ & $3.43 \mathrm{E}+04$ \\
\hline Bladder & $4.02 \mathrm{E}+05$ & $1.51 \mathrm{E}+05$ & $3.23 \mathrm{E}+03$ & $9.70 \mathrm{E}+04$ & $5.63 \mathrm{E}+04$ \\
\hline Lungs & $9.89 \mathrm{E}+04$ & $3.83 \mathrm{E}+04$ & $9.51 \mathrm{E}+02$ & $2.45 \mathrm{E}+04$ & $1.43 \mathrm{E}+04$ \\
\hline Bone & $1.92 \mathrm{E}+05$ & $8.11 \mathrm{E}+04$ & $4.70 \mathrm{E}+03$ & $4.82 \mathrm{E}+04$ & $2.92 \mathrm{E}+04$ \\
\hline Liver & $8.94 \mathrm{E}+04$ & $3.36 \mathrm{E}+04$ & $7.67 \mathrm{E}+02$ & $2.17 \mathrm{E}+04$ & $1.25 \mathrm{E}+04$ \\
\hline Thyroid & $1.68 \mathrm{E}+05$ & $6.48 \mathrm{E}+04$ & $2.06 \mathrm{E}+03$ & $4.19 \mathrm{E}+04$ & $2.45 \mathrm{E}+04$ \\
\hline Esophagus & $1.10 \mathrm{E}+05$ & $4.19 \mathrm{E}+04$ & $8.25 \mathrm{E}+02$ & $2.67 \mathrm{E}+04$ & $1.56 \mathrm{E}+04$ \\
\hline Skin & $2.12 \mathrm{E}+05$ & $1.03 \mathrm{E}+05$ & $1.61 \mathrm{E}+04$ & $6.29 \mathrm{E}+04$ & $3.86 \mathrm{E}+04$ \\
\hline Other & $1.09 \mathrm{E}+05$ & $4.11 \mathrm{E}+04$ & $8.77 \mathrm{E}+02$ & $2.67 \mathrm{E}+04$ & $1.55 \mathrm{E}+04$ \\
\hline Breast & $4.29 \mathrm{E}+05$ & $1.70 \mathrm{E}+05$ & $9.59 \mathrm{E}+03$ & $1.09 \mathrm{E}+05$ & $6.43 \mathrm{E}+04$ \\
\hline Total & $2.34 \mathrm{E}+06$ & $9.22 \mathrm{E}+05$ & $4.34 \mathrm{E}+04$ & $5.86 \mathrm{E}+05$ & $3.44 \mathrm{E}+05$ \\
\hline
\end{tabular}


Table K.5 Absorbed Dose to Organs for Postmenopausal Adipose Female Patient for $37 \mathrm{GBq} / \mathrm{m}^{2}$ Surface Contamination ( $\mathrm{mGy} / \mathrm{hr}$ )

\begin{tabular}{|l|ccccc|}
\hline Organ & ${ }^{\mathbf{6 0}} \mathbf{C o}$ & ${ }^{\mathbf{1 9 2}} \mathbf{I r}$ & ${ }^{\mathbf{2 4 1}} \mathbf{A m}$ & ${ }^{\mathbf{1 3 7}} \mathbf{C s}$ & ${ }^{\mathbf{1 3 1}} \mathbf{I}$ \\
\hline \hline Gonads & $1.35 \mathrm{E}+02$ & $5.14 \mathrm{E}+01$ & $7.72 \mathrm{E}-01$ & $3.19 \mathrm{E}+01$ & $1.87 \mathrm{E}+01$ \\
Stomach & $1.87 \mathrm{E}+02$ & $7.06 \mathrm{E}+01$ & $1.60 \mathrm{E}+00$ & $4.53 \mathrm{E}+01$ & $2.64 \mathrm{E}+01$ \\
Colon Wall & $2.23 \mathrm{E}+02$ & $8.25 \mathrm{E}+01$ & $1.75 \mathrm{E}+00$ & $5.35 \mathrm{E}+01$ & $3.10 \mathrm{E}+01$ \\
Bladder & $3.66 \mathrm{E}+02$ & $1.38 \mathrm{E}+02$ & $2.95 \mathrm{E}+00$ & $8.83 \mathrm{E}+01$ & $5.14 \mathrm{E}+01$ \\
Lungs & $9.38 \mathrm{E}+01$ & $3.64 \mathrm{E}+01$ & $8.77 \mathrm{E}-01$ & $2.32 \mathrm{E}+01$ & $1.36 \mathrm{E}+01$ \\
Bone & $1.88 \mathrm{E}+02$ & $8.05 \mathrm{E}+01$ & $4.50 \mathrm{E}+00$ & $4.72 \mathrm{E}+01$ & $2.88 \mathrm{E}+01$ \\
Liver & $8.08 \mathrm{E}+01$ & $3.03 \mathrm{E}+01$ & $6.65 \mathrm{E}-01$ & $1.95 \mathrm{E}+01$ & $1.13 \mathrm{E}+01$ \\
Thyroid & $2.75 \mathrm{E}+02$ & $1.07 \mathrm{E}+02$ & $3.45 \mathrm{E}+00$ & $6.86 \mathrm{E}+01$ & $4.02 \mathrm{E}+01$ \\
Esophagus & $1.09 \mathrm{E}+02$ & $4.20 \mathrm{E}+01$ & $8.07 \mathrm{E}-01$ & $2.66 \mathrm{E}+01$ & $1.54 \mathrm{E}+01$ \\
Skin & $1.87 \mathrm{E}+02$ & $9.11 \mathrm{E}+01$ & $1.45 \mathrm{E}+01$ & $5.57 \mathrm{E}+01$ & $3.42 \mathrm{E}+01$ \\
Other & $1.06 \mathrm{E}+02$ & $4.02 \mathrm{E}+01$ & $8.43 \mathrm{E}-01$ & $2.61 \mathrm{E}+01$ & $1.50 \mathrm{E}+01$ \\
Breast & $4.03 \mathrm{E}+02$ & $1.61 \mathrm{E}+02$ & $9.33 \mathrm{E}+00$ & $1.03 \mathrm{E}+02$ & $6.07 \mathrm{E}+01$ \\
\hline Total & $2.35 \mathrm{E}+03$ & $9.31 \mathrm{E}+02$ & $4.20 \mathrm{E}+01$ & $5.89 \mathrm{E}+02$ & $3.47 \mathrm{E}+02$ \\
\hline
\end{tabular}




\section{APPENDIX L}

\section{ABSORBED DOSE TO ORGANS FOR HEALTHCARE PROVIDER DUE TO EXTERNALLY CONTAMINATED PATIENT}

Table L.1 Absorbed Dose to Organs for a Reference Male Healthcare Provider from Reference Male Patient for $37 \mathrm{GBq} / \mathrm{m}^{2}$ Surface Contamination (mGy/hr)

\begin{tabular}{|l|ccccc|}
\hline Organ & ${ }^{\mathbf{6 0}} \mathbf{C o}$ & ${ }^{\mathbf{1 9 2}} \mathbf{I r}$ & ${ }^{\mathbf{2 4 1}} \mathbf{A m}$ & ${ }^{\mathbf{1 3 7}} \mathbf{C s}$ & ${ }^{\mathbf{1 3 1}} \mathbf{I}$ \\
\hline \hline Gonads & $2.58 \mathrm{E}+00$ & $8.77 \mathrm{E}-01$ & $1.46 \mathrm{E}-02$ & $5.95 \mathrm{E}-01$ & $3.17 \mathrm{E}-01$ \\
Stomach & $6.61 \mathrm{E}+00$ & $3.07 \mathrm{E}+00$ & $9.27 \mathrm{E}-02$ & $1.75 \mathrm{E}+00$ & $1.12 \mathrm{E}+00$ \\
Colon Wall & $8.56 \mathrm{E}+00$ & $3.76 \mathrm{E}+00$ & $9.81 \mathrm{E}-02$ & $2.19 \mathrm{E}+00$ & $1.38 \mathrm{E}+00$ \\
Bladder & $5.41 \mathrm{E}+00$ & $2.35 \mathrm{E}+00$ & $6.58 \mathrm{E}-02$ & $1.38 \mathrm{E}+00$ & $8.51 \mathrm{E}-01$ \\
Lungs & $1.59 \mathrm{E}+00$ & $6.61 \mathrm{E}-01$ & $1.80 \mathrm{E}-02$ & $4.05 \mathrm{E}-01$ & $2.44 \mathrm{E}-01$ \\
Bone & $2.13 \mathrm{E}+00$ & $8.99 \mathrm{E}-01$ & $4.69 \mathrm{E}-02$ & $5.26 \mathrm{E}-01$ & $3.22 \mathrm{E}-01$ \\
Liver & $8.97 \mathrm{E}-01$ & $3.96 \mathrm{E}-01$ & $1.13 \mathrm{E}-02$ & $2.34 \mathrm{E}-01$ & $1.46 \mathrm{E}-01$ \\
Thyroid & $9.09 \mathrm{E}-01$ & $3.85 \mathrm{E}-01$ & $1.10 \mathrm{E}-02$ & $2.34 \mathrm{E}-01$ & $1.43 \mathrm{E}-01$ \\
Esophagus & $4.54 \mathrm{E}-01$ & $1.65 \mathrm{E}-01$ & $2.81 \mathrm{E}-03$ & $1.03 \mathrm{E}-01$ & $6.25 \mathrm{E}-02$ \\
Skin & $9.98 \mathrm{E}-02$ & $4.24 \mathrm{E}-02$ & $5.15 \mathrm{E}-03$ & $2.61 \mathrm{E}-02$ & $1.57 \mathrm{E}-02$ \\
Other & $1.43 \mathrm{E}+00$ & $6.04 \mathrm{E}-01$ & $1.43 \mathrm{E}-02$ & $3.59 \mathrm{E}-01$ & $2.18 \mathrm{E}-01$ \\
\hline Total & $3.07 \mathrm{E}+01$ & $1.32 \mathrm{E}+01$ & $3.81 \mathrm{E}-01$ & $7.80 \mathrm{E}+00$ & $4.81 \mathrm{E}+00$ \\
\hline
\end{tabular}

Table L.2 Absorbed Dose to Organs for a Reference Male Healthcare Provider from Reference Female Patient for $37 \mathrm{GBq} / \mathrm{m}^{2}$ Surface Contamination $(\mathrm{mGy} / \mathrm{hr})$

\begin{tabular}{|l|ccccc|}
\hline Organ & ${ }^{\mathbf{6 0}} \mathbf{C o}$ & ${ }^{192} \mathbf{I r}$ & ${ }^{241} \mathbf{A m}$ & ${ }^{137} \mathbf{C s}$ & ${ }^{\mathbf{1 3 1}} \mathbf{I}$ \\
\hline \hline Gonads & $1.02 \mathrm{E}+01$ & $3.32 \mathrm{E}+00$ & $5.72 \mathrm{E}-02$ & $2.36 \mathrm{E}+00$ & $1.20 \mathrm{E}+00$ \\
Stomach & $4.64 \mathrm{E}+01$ & $2.17 \mathrm{E}+01$ & $6.61 \mathrm{E}-01$ & $1.24 \mathrm{E}+01$ & $7.92 \mathrm{E}+00$ \\
Colon Wall & $5.96 \mathrm{E}+01$ & $2.60 \mathrm{E}+01$ & $6.82 \mathrm{E}-01$ & $1.53 \mathrm{E}+01$ & $9.43 \mathrm{E}+00$ \\
Bladder & $9.07 \mathrm{E}+01$ & $3.84 \mathrm{E}+01$ & $1.09 \mathrm{E}+00$ & $2.31 \mathrm{E}+01$ & $1.42 \mathrm{E}+01$ \\
Lungs & $1.13 \mathrm{E}+01$ & $4.76 \mathrm{E}+00$ & $1.26 \mathrm{E}-01$ & $2.89 \mathrm{E}+00$ & $1.75 \mathrm{E}+00$ \\
Bone & $1.40 \mathrm{E}+01$ & $5.88 \mathrm{E}+00$ & $3.04 \mathrm{E}-01$ & $3.44 \mathrm{E}+00$ & $2.11 \mathrm{E}+00$ \\
Liver & $1.46 \mathrm{E}+01$ & $6.39 \mathrm{E}+00$ & $1.78 \mathrm{E}-01$ & $3.77 \mathrm{E}+00$ & $2.34 \mathrm{E}+00$ \\
Thyroid & $1.46 \mathrm{E}+01$ & $6.62 \mathrm{E}+00$ & $2.04 \mathrm{E}-01$ & $3.98 \mathrm{E}+00$ & $2.42 \mathrm{E}+00$ \\
Esophagus & $7.45 \mathrm{E}+00$ & $2.73 \mathrm{E}+00$ & $4.59 \mathrm{E}-02$ & $1.81 \mathrm{E}+00$ & $9.99 \mathrm{E}-01$ \\
Skin & $8.39 \mathrm{E}+00$ & $3.52 \mathrm{E}+00$ & $4.16 \mathrm{E}-01$ & $2.19 \mathrm{E}+00$ & $1.32 \mathrm{E}+00$ \\
Other & $1.19 \mathrm{E}+01$ & $5.08 \mathrm{E}+00$ & $1.19 \mathrm{E}-01$ & $3.10 \mathrm{E}+00$ & $1.88 \mathrm{E}+00$ \\
\hline Total & $2.89 \mathrm{E}+02$ & $1.24 \mathrm{E}+02$ & $3.88 \mathrm{E}+00$ & $7.43 \mathrm{E}+01$ & $4.56 \mathrm{E}+01$ \\
\hline
\end{tabular}


Table L.3 Absorbed Dose to Organs for a Reference Male Healthcare Provider from Adipose Male Patient for $37 \mathrm{GBq} / \mathrm{m}^{2}$ Surface Contamination $(\mathrm{mGy} / \mathrm{hr})$

\begin{tabular}{|l|ccccc|}
\hline Organ & ${ }^{\mathbf{6 0}} \mathbf{C o}$ & ${ }^{\mathbf{1 9 2}} \mathbf{I r}$ & ${ }^{\mathbf{2 4 1}} \mathbf{A m}$ & ${ }^{\mathbf{1 3 7}} \mathbf{C s}$ & ${ }^{\mathbf{1 3 1} \mathbf{I}}$ \\
\hline \hline Gonads & $1.38 \mathrm{E}+01$ & $4.54 \mathrm{E}+00$ & $8.74 \mathrm{E}-02$ & $3.16 \mathrm{E}+00$ & $1.68 \mathrm{E}+00$ \\
Stomach & $5.69 \mathrm{E}+01$ & $2.54 \mathrm{E}+01$ & $7.21 \mathrm{E}-01$ & $1.49 \mathrm{E}+01$ & $9.30 \mathrm{E}+00$ \\
Colon Wall & $7.39 \mathrm{E}+01$ & $3.08 \mathrm{E}+01$ & $7.52 \mathrm{E}-01$ & $1.84 \mathrm{E}+01$ & $1.13 \mathrm{E}+01$ \\
Bladder & $1.23 \mathrm{E}+02$ & $5.14 \mathrm{E}+01$ & $1.40 \mathrm{E}+00$ & $3.12 \mathrm{E}+01$ & $1.90 \mathrm{E}+01$ \\
Lungs & $1.45 \mathrm{E}+01$ & $5.89 \mathrm{E}+00$ & $1.50 \mathrm{E}-01$ & $3.63 \mathrm{E}+00$ & $2.16 \mathrm{E}+00$ \\
Bone & $1.87 \mathrm{E}+01$ & $7.65 \mathrm{E}+00$ & $3.85 \mathrm{E}-01$ & $4.52 \mathrm{E}+00$ & $2.74 \mathrm{E}+00$ \\
Liver & $1.74 \mathrm{E}+01$ & $7.31 \mathrm{E}+00$ & $1.93 \mathrm{E}-01$ & $4.40 \mathrm{E}+00$ & $2.69 \mathrm{E}+00$ \\
Thyroid & $2.02 \mathrm{E}+01$ & $8.83 \mathrm{E}+00$ & $2.67 \mathrm{E}-01$ & $5.34 \mathrm{E}+00$ & $3.19 \mathrm{E}+00$ \\
Esophagus & $1.02 \mathrm{E}+01$ & $3.44 \mathrm{E}+00$ & $6.02 \mathrm{E}-02$ & $2.22 \mathrm{E}+00$ & $1.30 \mathrm{E}+00$ \\
Skin & $1.09 \mathrm{E}+01$ & $4.40 \mathrm{E}+00$ & $4.73 \mathrm{E}-01$ & $2.77 \mathrm{E}+00$ & $1.64 \mathrm{E}+00$ \\
Other & $1.49 \mathrm{E}+01$ & $5.85 \mathrm{E}+00$ & $1.42 \mathrm{E}-01$ & $3.80 \mathrm{E}+00$ & $2.28 \mathrm{E}+00$ \\
\hline Total & $3.74 \mathrm{E}+02$ & $1.55 \mathrm{E}+02$ & $4.63 \mathrm{E}+00$ & $9.43 \mathrm{E}+01$ & $5.73 \mathrm{E}+01$ \\
\hline
\end{tabular}

Table L.4 Absorbed Dose to Organs for a Reference Male Healthcare Provider from Adipose Female Patient for $37 \mathrm{GBq} / \mathrm{m}^{2}$ Surface Contamination $(\mathrm{mGy} / \mathrm{hr})$

\begin{tabular}{|l|ccccc|}
\hline Organ & ${ }^{\mathbf{6 0}} \mathbf{C o}$ & ${ }^{192} \mathbf{I r}$ & ${ }^{241} \mathbf{A m}$ & ${ }^{137} \mathbf{C s}$ & ${ }^{\mathbf{1 3 1}} \mathbf{I}$ \\
\hline \hline Gonads & $4.18 \mathrm{E}-01$ & $3.03 \mathrm{E}-01$ & $2.06 \mathrm{E}-01$ & $3.79 \mathrm{E}-01$ & $3.40 \mathrm{E}-01$ \\
Stomach & $1.83 \mathrm{E}+00$ & $1.96 \mathrm{E}+00$ & $2.09 \mathrm{E}+00$ & $1.88 \mathrm{E}+00$ & $1.94 \mathrm{E}+00$ \\
Colon Wall & $2.28 \mathrm{E}+00$ & $2.36 \mathrm{E}+00$ & $2.09 \mathrm{E}+00$ & $2.32 \mathrm{E}+00$ & $2.32 \mathrm{E}+00$ \\
Bladder & $3.44 \mathrm{E}+00$ & $3.53 \mathrm{E}+00$ & $3.44 \mathrm{E}+00$ & $3.49 \mathrm{E}+00$ & $3.56 \mathrm{E}+00$ \\
Lungs & $4.41 \mathrm{E}-01$ & $4.38 \mathrm{E}-01$ & $4.04 \mathrm{E}-01$ & $4.45 \mathrm{E}-01$ & $4.37 \mathrm{E}-01$ \\
Bone & $5.45 \mathrm{E}-01$ & $5.38 \mathrm{E}-01$ & $9.67 \mathrm{E}-01$ & $5.25 \mathrm{E}-01$ & $5.24 \mathrm{E}-01$ \\
Liver & $5.59 \mathrm{E}-01$ & $5.68 \mathrm{E}-01$ & $5.45 \mathrm{E}-01$ & $5.63 \mathrm{E}-01$ & $5.69 \mathrm{E}-01$ \\
Thyroid & $6.60 \mathrm{E}-01$ & $6.36 \mathrm{E}-01$ & $5.87 \mathrm{E}-01$ & $6.55 \mathrm{E}-01$ & $6.23 \mathrm{E}-01$ \\
Esophagus & $3.03 \mathrm{E}-01$ & $2.69 \mathrm{E}-01$ & $1.59 \mathrm{E}-01$ & $2.81 \mathrm{E}-01$ & $2.70 \mathrm{E}-01$ \\
Skin & $3.28 \mathrm{E}-01$ & $3.22 \mathrm{E}-01$ & $1.28 \mathrm{E}+00$ & $3.34 \mathrm{E}-01$ & $3.26 \mathrm{E}-01$ \\
Other & $4.73 \mathrm{E}-01$ & $4.51 \mathrm{E}-01$ & $3.43 \mathrm{E}-01$ & $4.60 \mathrm{E}-01$ & $4.60 \mathrm{E}-01$ \\
\hline Total & $1.13 \mathrm{E}+01$ & $1.14 \mathrm{E}+01$ & $1.21 \mathrm{E}+01$ & $1.13 \mathrm{E}+01$ & $1.14 \mathrm{E}+01$ \\
\hline
\end{tabular}


Table L.5 Absorbed Dose to Organs for a Reference Male Healthcare Provider from Postmenopausal Adipose Female Patient for $37 \mathrm{GBq} / \mathrm{m}^{2}$ Surface Contamination (mGy/hr)

\begin{tabular}{|l|ccccc|}
\hline Organ & ${ }^{6 \mathbf{C}} \mathbf{C}$ & ${ }^{\mathbf{1 9 2}} \mathbf{I r}$ & ${ }^{241} \mathbf{A m}$ & ${ }^{137} \mathbf{C s}$ & ${ }^{131} \mathbf{I}$ \\
\hline \hline Gonads & $1.29 \mathrm{E}+01$ & $4.23 \mathrm{E}+00$ & $8.02 \mathrm{E}-02$ & $2.94 \mathrm{E}+00$ & $1.58 \mathrm{E}+00$ \\
Stomach & $5.40 \mathrm{E}+01$ & $2.45 \mathrm{E}+01$ & $7.33 \mathrm{E}-01$ & $1.42 \mathrm{E}+01$ & $8.85 \mathrm{E}+00$ \\
Colon Wall & $6.92 \mathrm{E}+01$ & $2.98 \mathrm{E}+01$ & $7.53 \mathrm{E}-01$ & $1.78 \mathrm{E}+01$ & $1.09 \mathrm{E}+01$ \\
Bladder & $1.12 \mathrm{E}+02$ & $4.76 \mathrm{E}+01$ & $1.30 \mathrm{E}+00$ & $2.89 \mathrm{E}+01$ & $1.76 \mathrm{E}+01$ \\
Lungs & $1.36 \mathrm{E}+01$ & $5.54 \mathrm{E}+00$ & $1.46 \mathrm{E}-01$ & $3.40 \mathrm{E}+00$ & $2.04 \mathrm{E}+00$ \\
Bone & $1.69 \mathrm{E}+01$ & $7.05 \mathrm{E}+00$ & $3.62 \mathrm{E}-01$ & $4.14 \mathrm{E}+00$ & $2.53 \mathrm{E}+00$ \\
Liver & $1.67 \mathrm{E}+01$ & $7.16 \mathrm{E}+00$ & $1.96 \mathrm{E}-01$ & $4.27 \mathrm{E}+00$ & $2.63 \mathrm{E}+00$ \\
Thyroid & $1.91 \mathrm{E}+01$ & $8.02 \mathrm{E}+00$ & $2.28 \mathrm{E}-01$ & $5.00 \mathrm{E}+00$ & $3.05 \mathrm{E}+00$ \\
Esophagus & $9.03 \mathrm{E}+00$ & $3.28 \mathrm{E}+00$ & $6.26 \mathrm{E}-02$ & $2.13 \mathrm{E}+00$ & $1.25 \mathrm{E}+00$ \\
Skin & $1.00 \mathrm{E}+01$ & $4.14 \mathrm{E}+00$ & $4.63 \mathrm{E}-01$ & $2.60 \mathrm{E}+00$ & $1.54 \mathrm{E}+00$ \\
Other & $1.45 \mathrm{E}+01$ & $5.88 \mathrm{E}+00$ & $1.41 \mathrm{E}-01$ & $3.51 \mathrm{E}+00$ & $2.13 \mathrm{E}+00$ \\
\hline Total & $3.48 \mathrm{E}+02$ & $1.47 \mathrm{E}+02$ & $4.46 \mathrm{E}+00$ & $8.88 \mathrm{E}+01$ & $5.41 \mathrm{E}+01$ \\
\hline
\end{tabular}

Table L.6 Absorbed Dose to Organs for a Reference Female Healthcare Provider from Reference Male Patient for $37 \mathrm{GBq} / \mathrm{m}^{2}$ Surface Contamination $(\mathrm{mGy} / \mathrm{hr}$ )

\begin{tabular}{|l|ccccc|}
\hline Organ & Co-60 & Ir-192 & Am-241 & Cs-137 & I-131 \\
\hline \hline Gonads & $1.79 \mathrm{E}+01$ & $7.73 \mathrm{E}+00$ & $1.69 \mathrm{E}-01$ & $4.72 \mathrm{E}+00$ & $2.73 \mathrm{E}+00$ \\
Stomach & $5.14 \mathrm{E}+01$ & $2.42 \mathrm{E}+01$ & $7.67 \mathrm{E}-01$ & $1.37 \mathrm{E}+01$ & $8.79 \mathrm{E}+00$ \\
Colon Wall & $6.05 \mathrm{E}+01$ & $2.68 \mathrm{E}+01$ & $6.97 \mathrm{E}-01$ & $1.57 \mathrm{E}+01$ & $9.82 \mathrm{E}+00$ \\
Bladder & $1.05 \mathrm{E}+02$ & $4.49 \mathrm{E}+01$ & $1.25 \mathrm{E}+00$ & $2.65 \mathrm{E}+01$ & $1.64 \mathrm{E}+01$ \\
Lungs & $1.41 \mathrm{E}+01$ & $5.82 \mathrm{E}+00$ & $1.51 \mathrm{E}-01$ & $3.54 \mathrm{E}+00$ & $2.14 \mathrm{E}+00$ \\
Bone & $1.75 \mathrm{E}+01$ & $7.38 \mathrm{E}+00$ & $3.72 \mathrm{E}-01$ & $4.32 \mathrm{E}+00$ & $2.65 \mathrm{E}+00$ \\
Liver & $1.93 \mathrm{E}+01$ & $8.60 \mathrm{E}+00$ & $2.48 \mathrm{E}-01$ & $5.04 \mathrm{E}+00$ & $3.15 \mathrm{E}+00$ \\
Thyroid & $1.61 \mathrm{E}+01$ & $6.99 \mathrm{E}+00$ & $2.19 \mathrm{E}-01$ & $4.35 \mathrm{E}+00$ & $2.60 \mathrm{E}+00$ \\
Esophagus & $1.10 \mathrm{E}+01$ & $4.09 \mathrm{E}+00$ & $6.74 \mathrm{E}-02$ & $2.60 \mathrm{E}+00$ & $1.58 \mathrm{E}+00$ \\
Skin & $1.52 \mathrm{E}+01$ & $6.33 \mathrm{E}+00$ & $6.99 \mathrm{E}-01$ & $3.93 \mathrm{E}+00$ & $2.35 \mathrm{E}+00$ \\
Other & $1.59 \mathrm{E}+01$ & $6.64 \mathrm{E}+00$ & $1.49 \mathrm{E}-01$ & $4.06 \mathrm{E}+00$ & $2.33 \mathrm{E}+00$ \\
Breasts & $5.25 \mathrm{E}+01$ & $2.39 \mathrm{E}+01$ & $1.40 \mathrm{E}+00$ & $1.40 \mathrm{E}+01$ & $8.77 \mathrm{E}+00$ \\
\hline Total & $3.97 \mathrm{E}+02$ & $1.73 \mathrm{E}+02$ & $6.18 \mathrm{E}+00$ & $1.02 \mathrm{E}+02$ & $6.33 \mathrm{E}+01$ \\
\hline
\end{tabular}


Table L.7 Absorbed Dose to Organs for a Reference Female Healthcare Provider from Reference Female Patient for $37 \mathrm{GBq} / \mathrm{m}^{2}$ Surface Contamination $(\mathrm{mGy} / \mathrm{hr}$ )

\begin{tabular}{|l|ccccc|}
\hline Organ & ${ }^{60} \mathbf{C o}$ & ${ }^{\mathbf{1 9 2}} \mathbf{I r}$ & ${ }^{241} \mathbf{A m}$ & ${ }^{137} \mathbf{C s}$ & ${ }^{\mathbf{1 3 1}} \mathbf{I}$ \\
\hline \hline Gonads & $1.58 \mathrm{E}+01$ & $6.17 \mathrm{E}+00$ & $1.42 \mathrm{E}-01$ & $4.07 \mathrm{E}+00$ & $2.37 \mathrm{E}+00$ \\
Stomach & $4.32 \mathrm{E}+01$ & $2.04 \mathrm{E}+01$ & $6.46 \mathrm{E}-01$ & $1.17 \mathrm{E}+01$ & $7.42 \mathrm{E}+00$ \\
Colon Wall & $5.06 \mathrm{E}+01$ & $2.21 \mathrm{E}+01$ & $5.65 \mathrm{E}-01$ & $1.30 \mathrm{E}+01$ & $8.08 \mathrm{E}+00$ \\
Bladder & $8.88 \mathrm{E}+01$ & $3.73 \mathrm{E}+01$ & $1.03 \mathrm{E}+00$ & $2.26 \mathrm{E}+01$ & $1.38 \mathrm{E}+01$ \\
Lungs & $1.19 \mathrm{E}+01$ & $4.93 \mathrm{E}+00$ & $1.27 \mathrm{E}-01$ & $3.02 \mathrm{E}+00$ & $1.82 \mathrm{E}+00$ \\
Bone & $1.49 \mathrm{E}+01$ & $6.26 \mathrm{E}+00$ & $3.15 \mathrm{E}-01$ & $3.67 \mathrm{E}+00$ & $2.24 \mathrm{E}+00$ \\
Liver & $1.54 \mathrm{E}+01$ & $6.89 \mathrm{E}+00$ & $1.94 \mathrm{E}-01$ & $4.03 \mathrm{E}+00$ & $2.51 \mathrm{E}+00$ \\
Thyroid & $1.44 \mathrm{E}+01$ & $5.98 \mathrm{E}+00$ & $2.06 \mathrm{E}-01$ & $3.75 \mathrm{E}+00$ & $2.23 \mathrm{E}+00$ \\
Esophagus & $9.84 \mathrm{E}+00$ & $3.79 \mathrm{E}+00$ & $6.43 \mathrm{E}-02$ & $2.43 \mathrm{E}+00$ & $1.39 \mathrm{E}+00$ \\
Skin & $1.28 \mathrm{E}+01$ & $5.25 \mathrm{E}+00$ & $5.66 \mathrm{E}-01$ & $3.31 \mathrm{E}+00$ & $1.97 \mathrm{E}+00$ \\
Other & $1.27 \mathrm{E}+01$ & $5.45 \mathrm{E}+00$ & $1.33 \mathrm{E}-01$ & $3.30 \mathrm{E}+00$ & $1.99 \mathrm{E}+00$ \\
Breasts & $4.46 \mathrm{E}+01$ & $2.00 \mathrm{E}+01$ & $1.14 \mathrm{E}+00$ & $1.19 \mathrm{E}+01$ & $7.39 \mathrm{E}+00$ \\
\hline Total & $3.35 \mathrm{E}+02$ & $1.45 \mathrm{E}+02$ & $5.13 \mathrm{E}+00$ & $8.67 \mathrm{E}+01$ & $5.32 \mathrm{E}+01$ \\
\hline
\end{tabular}

Table L. 8 Absorbed Dose to Organs for a Reference Female Healthcare Provider from Adipose Male Patient for $37 \mathrm{GBq} / \mathrm{m}^{2}$ Surface Contamination (mGy/hr)

\begin{tabular}{|l|ccccc|}
\hline Organ & ${ }^{60} \mathbf{C o}$ & ${ }^{\mathbf{1 9 2}} \mathbf{I r}$ & ${ }^{\mathbf{2 4 1}} \mathbf{A m}$ & ${ }^{\mathbf{1 3 7}} \mathbf{C s}$ & ${ }^{\mathbf{1 3 1}} \mathbf{I}$ \\
\hline \hline Gonads & $1.81 \mathrm{E}+01$ & $7.58 \mathrm{E}+00$ & $1.75 \mathrm{E}-01$ & $4.69 \mathrm{E}+00$ & $2.80 \mathrm{E}+00$ \\
Stomach & $5.19 \mathrm{E}+01$ & $2.36 \mathrm{E}+01$ & $7.10 \mathrm{E}-01$ & $1.36 \mathrm{E}+01$ & $8.65 \mathrm{E}+00$ \\
Colon Wall & $6.25 \mathrm{E}+01$ & $2.63 \mathrm{E}+01$ & $6.39 \mathrm{E}-01$ & $1.58 \mathrm{E}+01$ & $9.64 \mathrm{E}+00$ \\
Bladder & $1.21 \mathrm{E}+02$ & $5.03 \mathrm{E}+01$ & $1.33 \mathrm{E}+00$ & $3.06 \mathrm{E}+01$ & $1.87 \mathrm{E}+01$ \\
Lungs & $1.51 \mathrm{E}+01$ & $6.08 \mathrm{E}+00$ & $1.50 \mathrm{E}-01$ & $3.79 \mathrm{E}+00$ & $2.23 \mathrm{E}+00$ \\
Bone & $1.98 \mathrm{E}+01$ & $8.10 \mathrm{E}+00$ & $3.96 \mathrm{E}-01$ & $4.80 \mathrm{E}+00$ & $2.91 \mathrm{E}+00$ \\
Liver & $1.85 \mathrm{E}+01$ & $7.78 \mathrm{E}+00$ & $2.10 \mathrm{E}-01$ & $4.68 \mathrm{E}+00$ & $2.85 \mathrm{E}+00$ \\
Thyroid & $1.85 \mathrm{E}+01$ & $7.74 \mathrm{E}+00$ & $2.63 \mathrm{E}-01$ & $4.66 \mathrm{E}+00$ & $3.01 \mathrm{E}+00$ \\
Esophagus & $1.25 \mathrm{E}+01$ & $4.46 \mathrm{E}+00$ & $7.15 \mathrm{E}-02$ & $3.17 \mathrm{E}+00$ & $1.69 \mathrm{E}+00$ \\
Skin & $1.66 \mathrm{E}+01$ & $6.54 \mathrm{E}+00$ & $6.43 \mathrm{E}-01$ & $4.18 \mathrm{E}+00$ & $2.45 \mathrm{E}+00$ \\
Other & $1.63 \mathrm{E}+01$ & $6.75 \mathrm{E}+00$ & $1.46 \mathrm{E}-01$ & $4.13 \mathrm{E}+00$ & $2.41 \mathrm{E}+00$ \\
Breasts & $5.52 \mathrm{E}+01$ & $2.40 \mathrm{E}+01$ & $1.28 \mathrm{E}+00$ & $1.44 \mathrm{E}+01$ & $8.81 \mathrm{E}+00$ \\
\hline Total & $4.26 \mathrm{E}+02$ & $1.79 \mathrm{E}+02$ & $6.01 \mathrm{E}+00$ & $1.09 \mathrm{E}+02$ & $6.62 \mathrm{E}+01$ \\
\hline
\end{tabular}


Table L.9 Absorbed Dose to Organs for a Reference Female Healthcare Provider from Adipose Female Patient for $37 \mathrm{GBq} / \mathrm{m}^{2}$ Surface Contamination $(\mathrm{mGy} / \mathrm{hr})$

\begin{tabular}{|l|ccccc|}
\hline Organ & ${ }^{\mathbf{6 0}} \mathbf{C o}$ & ${ }^{\mathbf{1 9 2}} \mathbf{I r}$ & ${ }^{\mathbf{2 4 1}} \mathbf{A m}$ & ${ }^{\mathbf{1 3 7}} \mathbf{C s}$ & ${ }^{\mathbf{1 3 1}} \mathbf{I}$ \\
\hline \hline Gonads & $1.77 \mathrm{E}+01$ & $7.27 \mathrm{E}+00$ & $1.76 \mathrm{E}-01$ & $4.33 \mathrm{E}+00$ & $2.85 \mathrm{E}+00$ \\
Stomach & $5.28 \mathrm{E}+01$ & $2.46 \mathrm{E}+01$ & $7.74 \mathrm{E}-01$ & $1.41 \mathrm{E}+01$ & $8.90 \mathrm{E}+00$ \\
Colon Wall & $6.17 \mathrm{E}+01$ & $2.70 \mathrm{E}+01$ & $6.82 \mathrm{E}-01$ & $1.59 \mathrm{E}+01$ & $9.83 \mathrm{E}+00$ \\
Bladder & $1.04 \mathrm{E}+02$ & $4.49 \mathrm{E}+01$ & $1.24 \mathrm{E}+00$ & $2.68 \mathrm{E}+01$ & $1.66 \mathrm{E}+01$ \\
Lungs & $1.45 \mathrm{E}+01$ & $5.95 \mathrm{E}+00$ & $1.52 \mathrm{E}-01$ & $3.65 \mathrm{E}+00$ & $2.19 \mathrm{E}+00$ \\
Bone & $1.81 \mathrm{E}+01$ & $7.60 \mathrm{E}+00$ & $3.85 \mathrm{E}-01$ & $4.44 \mathrm{E}+00$ & $2.72 \mathrm{E}+00$ \\
Liver & $1.87 \mathrm{E}+01$ & $8.18 \mathrm{E}+00$ & $2.33 \mathrm{E}-01$ & $4.82 \mathrm{E}+00$ & $3.00 \mathrm{E}+00$ \\
Thyroid & $1.83 \mathrm{E}+01$ & $7.43 \mathrm{E}+00$ & $2.56 \mathrm{E}-01$ & $4.62 \mathrm{E}+00$ & $2.84 \mathrm{E}+00$ \\
Esophagus & $1.14 \mathrm{E}+01$ & $4.17 \mathrm{E}+00$ & $7.78 \mathrm{E}-02$ & $2.75 \mathrm{E}+00$ & $1.58 \mathrm{E}+00$ \\
Skin & $1.55 \mathrm{E}+01$ & $6.38 \mathrm{E}+00$ & $6.75 \mathrm{E}-01$ & $4.00 \mathrm{E}+00$ & $2.37 \mathrm{E}+00$ \\
Other & $1.55 \mathrm{E}+01$ & $6.36 \mathrm{E}+00$ & $1.51 \mathrm{E}-01$ & $3.91 \mathrm{E}+00$ & $2.37 \mathrm{E}+00$ \\
Breasts & $5.44 \mathrm{E}+01$ & $2.43 \mathrm{E}+01$ & $1.36 \mathrm{E}+00$ & $1.44 \mathrm{E}+01$ & $8.95 \mathrm{E}+00$ \\
\hline Total & $4.02 \mathrm{E}+02$ & $1.74 \mathrm{E}+02$ & $6.16 \mathrm{E}+00$ & $1.04 \mathrm{E}+02$ & $6.42 \mathrm{E}+01$ \\
\hline
\end{tabular}

Table L.10 Absorbed Dose to Organs for a Reference Female Healthcare Provider from Postmenopausal Adipose Female Patient for $37 \mathrm{GBq} / \mathrm{m}^{2}$ Surface Contamination (mGy/hr)

\begin{tabular}{|l|ccccc|}
\hline Organ & ${ }^{\mathbf{6 0}} \mathbf{C o}$ & ${ }^{\mathbf{1 9 2}} \mathbf{I r}$ & ${ }^{\mathbf{2 4 1}} \mathbf{A m}$ & ${ }^{\mathbf{1 3 7}} \mathbf{C s}$ & ${ }^{\mathbf{1 3 1}} \mathbf{I}$ \\
\hline \hline Gonads & $1.75 \mathrm{E}+01$ & $7.12 \mathrm{E}+00$ & $1.69 \mathrm{E}-01$ & $4.46 \mathrm{E}+00$ & $2.72 \mathrm{E}+00$ \\
Stomach & $5.05 \mathrm{E}+01$ & $2.30 \mathrm{E}+01$ & $7.21 \mathrm{E}-01$ & $1.34 \mathrm{E}+01$ & $8.34 \mathrm{E}+00$ \\
Colon Wall & $5.99 \mathrm{E}+01$ & $2.56 \mathrm{E}+01$ & $6.41 \mathrm{E}-01$ & $1.55 \mathrm{E}+01$ & $9.37 \mathrm{E}+00$ \\
Bladder & $1.09 \mathrm{E}+02$ & $4.62 \mathrm{E}+01$ & $1.25 \mathrm{E}+00$ & $2.79 \mathrm{E}+01$ & $1.71 \mathrm{E}+01$ \\
Lungs & $1.40 \mathrm{E}+01$ & $5.66 \mathrm{E}+00$ & $1.42 \mathrm{E}-01$ & $3.50 \mathrm{E}+00$ & $2.09 \mathrm{E}+00$ \\
Bone & $1.80 \mathrm{E}+01$ & $7.48 \mathrm{E}+00$ & $3.71 \mathrm{E}-01$ & $4.40 \mathrm{E}+00$ & $2.68 \mathrm{E}+00$ \\
Liver & $1.76 \mathrm{E}+01$ & $7.71 \mathrm{E}+00$ & $2.14 \mathrm{E}-01$ & $4.56 \mathrm{E}+00$ & $2.83 \mathrm{E}+00$ \\
Thyroid & $1.76 \mathrm{E}+01$ & $7.30 \mathrm{E}+00$ & $2.34 \mathrm{E}-01$ & $4.71 \mathrm{E}+00$ & $2.68 \mathrm{E}+00$ \\
Esophagus & $1.18 \mathrm{E}+01$ & $4.26 \mathrm{E}+00$ & $7.67 \mathrm{E}-02$ & $2.89 \mathrm{E}+00$ & $1.58 \mathrm{E}+00$ \\
Skin & $1.52 \mathrm{E}+01$ & $6.18 \mathrm{E}+00$ & $6.31 \mathrm{E}-01$ & $3.90 \mathrm{E}+00$ & $2.30 \mathrm{E}+00$ \\
Other & $1.46 \mathrm{E}+01$ & $6.36 \mathrm{E}+00$ & $1.47 \mathrm{E}-01$ & $3.80 \mathrm{E}+00$ & $2.30 \mathrm{E}+00$ \\
Breasts & $5.17 \mathrm{E}+01$ & $2.30 \mathrm{E}+01$ & $1.25 \mathrm{E}+00$ & $1.36 \mathrm{E}+01$ & $8.44 \mathrm{E}+00$ \\
\hline Total & $3.97 \mathrm{E}+02$ & $1.70 \mathrm{E}+02$ & $5.85 \mathrm{E}+00$ & $1.03 \mathrm{E}+02$ & $6.25 \mathrm{E}+01$ \\
\hline
\end{tabular}


Table L.11 Absorbed Dose to Organs for an Adipose Male Healthcare Provider from Reference Male Patient for $37 \mathrm{GBq} / \mathrm{m}^{2}$ Surface Contamination $(\mathrm{mGy} / \mathrm{hr}$ )

\begin{tabular}{|l|ccccc|}
\hline Organ & ${ }^{\mathbf{6 0}} \mathbf{C o}$ & ${ }^{\mathbf{1 9 2}} \mathbf{I r}$ & ${ }^{\mathbf{2 4 1}} \mathbf{A m}$ & ${ }^{\mathbf{1 3 7}} \mathbf{C s}$ & ${ }^{\mathbf{1 3 1}} \mathbf{I}$ \\
\hline \hline Gonads & $1.68 \mathrm{E}+01$ & $6.12 \mathrm{E}+00$ & $1.53 \mathrm{E}-01$ & $4.13 \mathrm{E}+00$ & $2.33 \mathrm{E}+00$ \\
Stomach & $4.26 \mathrm{E}+01$ & $1.81 \mathrm{E}+01$ & $4.18 \mathrm{E}-01$ & $1.10 \mathrm{E}+01$ & $6.62 \mathrm{E}+00$ \\
Colon Wall & $4.81 \mathrm{E}+01$ & $1.79 \mathrm{E}+01$ & $2.84 \mathrm{E}-01$ & $1.16 \mathrm{E}+01$ & $6.63 \mathrm{E}+00$ \\
Bladder & $7.57 \mathrm{E}+01$ & $2.83 \mathrm{E}+01$ & $4.23 \mathrm{E}-01$ & $1.84 \mathrm{E}+01$ & $1.06 \mathrm{E}+01$ \\
Lungs & $1.15 \mathrm{E}+01$ & $4.59 \mathrm{E}+00$ & $1.03 \mathrm{E}-01$ & $2.91 \mathrm{E}+00$ & $1.70 \mathrm{E}+00$ \\
Bone & $1.47 \mathrm{E}+01$ & $6.19 \mathrm{E}+00$ & $2.28 \mathrm{E}-01$ & $3.65 \mathrm{E}+00$ & $2.22 \mathrm{E}+00$ \\
Liver & $1.46 \mathrm{E}+01$ & $6.07 \mathrm{E}+00$ & $1.35 \mathrm{E}-01$ & $3.73 \mathrm{E}+00$ & $2.25 \mathrm{E}+00$ \\
Thyroid & $1.61 \mathrm{E}+01$ & $6.31 \mathrm{E}+00$ & $1.40 \mathrm{E}-01$ & $3.92 \mathrm{E}+00$ & $2.30 \mathrm{E}+00$ \\
Esophagus & $7.75 \mathrm{E}+00$ & $2.64 \mathrm{E}+00$ & $3.79 \mathrm{E}-02$ & $1.79 \mathrm{E}+00$ & $1.03 \mathrm{E}+00$ \\
Skin & $1.13 \mathrm{E}+01$ & $4.84 \mathrm{E}+00$ & $5.51 \mathrm{E}-01$ & $3.02 \mathrm{E}+00$ & $1.80 \mathrm{E}+00$ \\
Other & $1.02 \mathrm{E}+01$ & $3.91 \mathrm{E}+00$ & $7.40 \mathrm{E}-02$ & $2.50 \mathrm{E}+00$ & $1.41 \mathrm{E}+00$ \\
Breasts & $2.94 \mathrm{E}+01$ & $1.38 \mathrm{E}+01$ & $1.04 \mathrm{E}+00$ & $7.85 \mathrm{E}+00$ & $4.73 \mathrm{E}+00$ \\
\hline Total & $2.99 \mathrm{E}+02$ & $1.19 \mathrm{E}+02$ & $3.59 \mathrm{E}+00$ & $7.45 \mathrm{E}+01$ & $4.36 \mathrm{E}+01$ \\
\hline
\end{tabular}

Table L.12 Absorbed Dose to Organs for an Adipose Male Healthcare Provider from Reference Female Patient for $37 \mathrm{GBq} / \mathrm{m}^{2}$ Surface Contamination $(\mathrm{mGy} / \mathrm{hr})$

\begin{tabular}{|l|ccccc|}
\hline Organ & ${ }^{\mathbf{6 0}} \mathbf{C o}$ & ${ }^{\mathbf{1 9 2}} \mathbf{I r}$ & ${ }^{\mathbf{2 4 1}} \mathbf{A m}$ & ${ }^{\mathbf{1 3 7}} \mathbf{C s}$ & ${ }^{\mathbf{1 3 1}} \mathbf{I}$ \\
\hline \hline Gonads & $1.28 \mathrm{E}+01$ & $4.18 \mathrm{E}+00$ & $8.65 \mathrm{E}-02$ & $2.86 \mathrm{E}+00$ & $1.63 \mathrm{E}+00$ \\
Stomach & $3.74 \mathrm{E}+01$ & $1.57 \mathrm{E}+01$ & $3.70 \mathrm{E}-01$ & $9.53 \mathrm{E}+00$ & $5.81 \mathrm{E}+00$ \\
Colon Wall & $4.10 \mathrm{E}+01$ & $1.44 \mathrm{E}+01$ & $2.31 \mathrm{E}-01$ & $9.50 \mathrm{E}+00$ & $5.37 \mathrm{E}+00$ \\
Bladder & $6.16 \mathrm{E}+01$ & $2.08 \mathrm{E}+01$ & $3.17 \mathrm{E}-01$ & $1.42 \mathrm{E}+01$ & $7.89 \mathrm{E}+00$ \\
Lungs & $1.00 \mathrm{E}+01$ & $3.96 \mathrm{E}+00$ & $8.64 \mathrm{E}-02$ & $2.50 \mathrm{E}+00$ & $1.47 \mathrm{E}+00$ \\
Bone & $1.27 \mathrm{E}+01$ & $5.16 \mathrm{E}+00$ & $1.89 \mathrm{E}-01$ & $3.06 \mathrm{E}+00$ & $1.85 \mathrm{E}+00$ \\
Liver & $1.22 \mathrm{E}+01$ & $4.87 \mathrm{E}+00$ & $1.08 \mathrm{E}-01$ & $3.01 \mathrm{E}+00$ & $1.80 \mathrm{E}+00$ \\
Thyroid & $1.33 \mathrm{E}+01$ & $5.00 \mathrm{E}+00$ & $1.15 \mathrm{E}-01$ & $3.29 \mathrm{E}+00$ & $1.88 \mathrm{E}+00$ \\
Esophagus & $6.46 \mathrm{E}+00$ & $2.27 \mathrm{E}+00$ & $3.20 \mathrm{E}-02$ & $1.55 \mathrm{E}+00$ & $8.71 \mathrm{E}-01$ \\
Skin & $9.52 \mathrm{E}+00$ & $3.92 \mathrm{E}+00$ & $4.24 \mathrm{E}-01$ & $2.46 \mathrm{E}+00$ & $1.46 \mathrm{E}+00$ \\
Other & $8.84 \mathrm{E}+00$ & $3.31 \mathrm{E}+00$ & $5.80 \mathrm{E}-02$ & $2.19 \mathrm{E}+00$ & $1.22 \mathrm{E}+00$ \\
Breasts & $2.51 \mathrm{E}+01$ & $1.20 \mathrm{E}+01$ & $7.87 \mathrm{E}-01$ & $7.35 \mathrm{E}+00$ & $4.21 \mathrm{E}+00$ \\
\hline Total & $2.51 \mathrm{E}+02$ & $9.56 \mathrm{E}+01$ & $2.80 \mathrm{E}+00$ & $6.15 \mathrm{E}+01$ & $3.55 \mathrm{E}+01$ \\
\hline
\end{tabular}


Table L.13 Absorbed Dose to Organs for an Adipose Male Healthcare Provider from Adipose Male Patient for $37 \mathrm{GBq} / \mathrm{m}^{2}$ Surface Contamination $(\mathrm{mGy} / \mathrm{hr}$ )

\begin{tabular}{|l|ccccc|}
\hline Organ & ${ }^{\mathbf{6 0}} \mathbf{C o}$ & ${ }^{\mathbf{1 9 2}} \mathbf{I r}$ & ${ }^{\mathbf{2 4 1}} \mathbf{A m}$ & ${ }^{\mathbf{1 3 7}} \mathbf{C s}$ & ${ }^{\mathbf{1 3 1}} \mathbf{I}$ \\
\hline \hline Gonads & $1.72 \mathrm{E}+01$ & $6.33 \mathrm{E}+00$ & $1.39 \mathrm{E}-01$ & $4.21 \mathrm{E}+00$ & $2.37 \mathrm{E}+00$ \\
Stomach & $4.74 \mathrm{E}+01$ & $1.94 \mathrm{E}+01$ & $4.38 \mathrm{E}-01$ & $1.18 \mathrm{E}+01$ & $7.10 \mathrm{E}+00$ \\
Colon Wall & $5.21 \mathrm{E}+01$ & $1.82 \mathrm{E}+01$ & $2.81 \mathrm{E}-01$ & $1.19 \mathrm{E}+01$ & $6.86 \mathrm{E}+00$ \\
Bladder & $8.22 \mathrm{E}+01$ & $2.81 \mathrm{E}+01$ & $4.08 \mathrm{E}-01$ & $1.92 \mathrm{E}+01$ & $1.06 \mathrm{E}+01$ \\
Lungs & $1.30 \mathrm{E}+01$ & $4.94 \mathrm{E}+00$ & $1.06 \mathrm{E}-01$ & $3.14 \mathrm{E}+00$ & $1.82 \mathrm{E}+00$ \\
Bone & $1.71 \mathrm{E}+01$ & $6.82 \mathrm{E}+00$ & $2.48 \mathrm{E}-01$ & $4.08 \mathrm{E}+00$ & $2.45 \mathrm{E}+00$ \\
Liver & $1.49 \mathrm{E}+01$ & $5.82 \mathrm{E}+00$ & $1.25 \mathrm{E}-01$ & $3.63 \mathrm{E}+00$ & $2.16 \mathrm{E}+00$ \\
Thyroid & $1.78 \mathrm{E}+01$ & $6.69 \mathrm{E}+00$ & $1.70 \mathrm{E}-01$ & $4.20 \mathrm{E}+00$ & $2.51 \mathrm{E}+00$ \\
Esophagus & $9.03 \mathrm{E}+00$ & $2.89 \mathrm{E}+00$ & $3.98 \mathrm{E}-02$ & $1.94 \mathrm{E}+00$ & $1.11 \mathrm{E}+00$ \\
Skin & $1.20 \mathrm{E}+01$ & $4.69 \mathrm{E}+00$ & $4.53 \mathrm{E}-01$ & $3.01 \mathrm{E}+00$ & $1.75 \mathrm{E}+00$ \\
Other & $1.13 \mathrm{E}+01$ & $3.98 \mathrm{E}+00$ & $7.00 \mathrm{E}-02$ & $2.64 \mathrm{E}+00$ & $1.54 \mathrm{E}+00$ \\
Breasts & $3.53 \mathrm{E}+01$ & $1.43 \mathrm{E}+01$ & $9.44 \mathrm{E}-01$ & $9.00 \mathrm{E}+00$ & $5.03 \mathrm{E}+00$ \\
\hline Total & $3.29 \mathrm{E}+02$ & $1.22 \mathrm{E}+02$ & $3.42 \mathrm{E}+00$ & $7.88 \mathrm{E}+01$ & $4.53 \mathrm{E}+01$ \\
\hline
\end{tabular}

Table L.14 Absorbed Dose to Organs for an Adipose Male Healthcare Provider from Adipose Female Patient for $37 \mathrm{GBq} / \mathrm{m}^{2}$ Surface Contamination $(\mathrm{mGy} / \mathrm{hr})$

\begin{tabular}{|l|ccccc|}
\hline Organ & ${ }^{\mathbf{6 0}} \mathbf{C o}$ & ${ }^{\mathbf{1 9 2}} \mathbf{I r}$ & ${ }^{\mathbf{2 4 1}} \mathbf{A m}$ & ${ }^{\mathbf{1 3 7}} \mathbf{C s}$ & ${ }^{\mathbf{1 3 1} \mathbf{I}}$ \\
\hline \hline Gonads & $1.48 \mathrm{E}+01$ & $5.07 \mathrm{E}+00$ & $1.12 \mathrm{E}-01$ & $3.36 \mathrm{E}+00$ & $1.91 \mathrm{E}+00$ \\
Stomach & $4.65 \mathrm{E}+01$ & $1.93 \mathrm{E}+01$ & $4.58 \mathrm{E}-01$ & $1.17 \mathrm{E}+01$ & $7.12 \mathrm{E}+00$ \\
Colon Wall & $4.95 \mathrm{E}+01$ & $1.77 \mathrm{E}+01$ & $2.68 \mathrm{E}-01$ & $1.15 \mathrm{E}+01$ & $6.57 \mathrm{E}+00$ \\
Bladder & $7.23 \mathrm{E}+01$ & $2.51 \mathrm{E}+01$ & $3.63 \mathrm{E}-01$ & $1.65 \mathrm{E}+01$ & $9.41 \mathrm{E}+00$ \\
Lungs & $1.24 \mathrm{E}+01$ & $4.86 \mathrm{E}+00$ & $1.07 \mathrm{E}-01$ & $3.07 \mathrm{E}+00$ & $1.80 \mathrm{E}+00$ \\
Bone & $1.54 \mathrm{E}+01$ & $6.25 \mathrm{E}+00$ & $2.33 \mathrm{E}-01$ & $3.70 \mathrm{E}+00$ & $2.23 \mathrm{E}+00$ \\
Liver & $1.48 \mathrm{E}+01$ & $5.95 \mathrm{E}+00$ & $1.31 \mathrm{E}-01$ & $3.66 \mathrm{E}+00$ & $2.20 \mathrm{E}+00$ \\
Thyroid & $1.68 \mathrm{E}+01$ & $6.67 \mathrm{E}+00$ & $1.55 \mathrm{E}-01$ & $4.30 \mathrm{E}+00$ & $2.35 \mathrm{E}+00$ \\
Esophagus & $8.36 \mathrm{E}+00$ & $2.90 \mathrm{E}+00$ & $4.79 \mathrm{E}-02$ & $1.91 \mathrm{E}+00$ & $1.12 \mathrm{E}+00$ \\
Skin & $1.14 \mathrm{E}+01$ & $4.66 \mathrm{E}+00$ & $4.96 \mathrm{E}-01$ & $2.93 \mathrm{E}+00$ & $1.74 \mathrm{E}+00$ \\
Other & $1.09 \mathrm{E}+01$ & $3.90 \mathrm{E}+00$ & $6.50 \mathrm{E}-02$ & $2.58 \mathrm{E}+00$ & $1.42 \mathrm{E}+00$ \\
Breasts & $3.21 \mathrm{E}+01$ & $1.64 \mathrm{E}+01$ & $1.01 \mathrm{E}+00$ & $8.50 \mathrm{E}+00$ & $5.52 \mathrm{E}+00$ \\
\hline Total & $3.05 \mathrm{E}+02$ & $1.19 \mathrm{E}+02$ & $3.45 \mathrm{E}+00$ & $7.38 \mathrm{E}+01$ & $4.34 \mathrm{E}+01$ \\
\hline
\end{tabular}


Table L.15 Absorbed Dose to Organs for an Adipose Male Healthcare Provider from Postmenopausal Adipose Female Patient for $37 \mathrm{GBq} / \mathrm{m}^{2}$ Surface Contamination (mGy/hr)

\begin{tabular}{|l|ccccc|}
\hline Organ & ${ }^{\mathbf{6 0}} \mathbf{C o}$ & ${ }^{\mathbf{1 9 2}} \mathbf{I r}$ & ${ }^{\mathbf{2 4 1}} \mathbf{A m}$ & ${ }^{\mathbf{1 3 7}} \mathbf{C s}$ & ${ }^{\mathbf{1 3 1}} \mathbf{I}$ \\
\hline \hline Gonads & $1.45 \mathrm{E}+01$ & $5.09 \mathrm{E}+00$ & $1.11 \mathrm{E}-01$ & $3.47 \mathrm{E}+00$ & $1.92 \mathrm{E}+00$ \\
Stomach & $4.50 \mathrm{E}+01$ & $1.84 \mathrm{E}+01$ & $4.46 \mathrm{E}-01$ & $1.13 \mathrm{E}+01$ & $6.82 \mathrm{E}+00$ \\
Colon Wall & $4.92 \mathrm{E}+01$ & $1.69 \mathrm{E}+01$ & $2.68 \mathrm{E}-01$ & $1.12 \mathrm{E}+01$ & $6.47 \mathrm{E}+00$ \\
Bladder & $7.45 \mathrm{E}+01$ & $2.51 \mathrm{E}+01$ & $3.89 \mathrm{E}-01$ & $1.70 \mathrm{E}+01$ & $9.52 \mathrm{E}+00$ \\
Lungs & $1.21 \mathrm{E}+01$ & $4.68 \mathrm{E}+00$ & $1.02 \mathrm{E}-01$ & $2.95 \mathrm{E}+00$ & $1.74 \mathrm{E}+00$ \\
Bone & $1.54 \mathrm{E}+01$ & $6.22 \mathrm{E}+00$ & $2.29 \mathrm{E}-01$ & $3.68 \mathrm{E}+00$ & $2.22 \mathrm{E}+00$ \\
Liver & $1.42 \mathrm{E}+01$ & $5.66 \mathrm{E}+00$ & $1.23 \mathrm{E}-01$ & $3.50 \mathrm{E}+00$ & $2.09 \mathrm{E}+00$ \\
Thyroid & $1.68 \mathrm{E}+01$ & $6.39 \mathrm{E}+00$ & $1.55 \mathrm{E}-01$ & $4.15 \mathrm{E}+00$ & $2.54 \mathrm{E}+00$ \\
Esophagus & $7.95 \mathrm{E}+00$ & $2.71 \mathrm{E}+00$ & $4.01 \mathrm{E}-02$ & $1.86 \mathrm{E}+00$ & $1.05 \mathrm{E}+00$ \\
Skin & $1.12 \mathrm{E}+01$ & $4.45 \mathrm{E}+00$ & $4.50 \mathrm{E}-01$ & $2.84 \mathrm{E}+00$ & $1.67 \mathrm{E}+00$ \\
Other & $1.06 \mathrm{E}+01$ & $3.88 \mathrm{E}+00$ & $6.48 \mathrm{E}-02$ & $2.61 \mathrm{E}+00$ & $1.51 \mathrm{E}+00$ \\
Breasts & $3.02 \mathrm{E}+01$ & $1.45 \mathrm{E}+01$ & $9.51 \mathrm{E}-01$ & $7.88 \mathrm{E}+00$ & $5.00 \mathrm{E}+00$ \\
\hline Total & $3.02 \mathrm{E}+02$ & $1.14 \mathrm{E}+02$ & $3.33 \mathrm{E}+00$ & $7.24 \mathrm{E}+01$ & $4.25 \mathrm{E}+01$ \\
\hline
\end{tabular}

Table L.16 Absorbed Dose to Organs for an Adipose Female Healthcare Provider from Reference Male Patient for $37 \mathrm{GBq} / \mathrm{m}^{2}$ Surface Contamination $(\mathrm{mGy} / \mathrm{hr}$ )

\begin{tabular}{|l|ccccc|}
\hline Organ & ${ }^{\mathbf{6 0}} \mathbf{C o}$ & ${ }^{\mathbf{1 9 2}} \mathbf{I r}$ & ${ }^{\mathbf{2 4 1}} \mathbf{A m}$ & ${ }^{\mathbf{1 3 7}} \mathbf{C s}$ & ${ }^{131} \mathbf{I}$ \\
\hline \hline Gonads & $1.26 \mathrm{E}+01$ & $4.77 \mathrm{E}+00$ & $6.71 \mathrm{E}-02$ & $2.97 \mathrm{E}+00$ & $1.86 \mathrm{E}+00$ \\
Stomach & $4.58 \mathrm{E}+01$ & $1.98 \mathrm{E}+01$ & $5.28 \mathrm{E}-01$ & $1.18 \mathrm{E}+01$ & $7.19 \mathrm{E}+00$ \\
Colon Wall & $4.66 \mathrm{E}+01$ & $1.74 \mathrm{E}+01$ & $3.23 \mathrm{E}-01$ & $1.11 \mathrm{E}+01$ & $6.46 \mathrm{E}+00$ \\
Bladder & $8.60 \mathrm{E}+01$ & $3.22 \mathrm{E}+01$ & $5.78 \mathrm{E}-01$ & $2.06 \mathrm{E}+01$ & $1.20 \mathrm{E}+01$ \\
Lungs & $1.33 \mathrm{E}+01$ & $5.28 \mathrm{E}+00$ & $1.26 \mathrm{E}-01$ & $3.31 \mathrm{E}+00$ & $1.96 \mathrm{E}+00$ \\
Bone & $1.67 \mathrm{E}+01$ & $6.93 \mathrm{E}+00$ & $2.86 \mathrm{E}-01$ & $4.06 \mathrm{E}+00$ & $2.47 \mathrm{E}+00$ \\
Liver & $1.77 \mathrm{E}+01$ & $7.49 \mathrm{E}+00$ & $1.86 \mathrm{E}-01$ & $4.54 \mathrm{E}+00$ & $2.75 \mathrm{E}+00$ \\
Thyroid & $1.50 \mathrm{E}+01$ & $6.42 \mathrm{E}+00$ & $1.78 \mathrm{E}-01$ & $3.88 \mathrm{E}+00$ & $2.38 \mathrm{E}+00$ \\
Esophagus & $1.12 \mathrm{E}+01$ & $3.74 \mathrm{E}+00$ & $6.22 \mathrm{E}-02$ & $2.60 \mathrm{E}+00$ & $1.36 \mathrm{E}+00$ \\
Skin & $1.91 \mathrm{E}+01$ & $8.17 \mathrm{E}+00$ & $8.66 \mathrm{E}-01$ & $5.02 \mathrm{E}+00$ & $3.03 \mathrm{E}+00$ \\
Other & $1.35 \mathrm{E}+01$ & $5.02 \mathrm{E}+00$ & $9.75 \mathrm{E}-02$ & $3.30 \mathrm{E}+00$ & $1.88 \mathrm{E}+00$ \\
Breasts & $6.19 \mathrm{E}+01$ & $2.84 \mathrm{E}+01$ & $1.58 \mathrm{E}+00$ & $1.66 \mathrm{E}+01$ & $1.04 \mathrm{E}+01$ \\
\hline Total & $3.59 \mathrm{E}+02$ & $1.46 \mathrm{E}+02$ & $4.88 \mathrm{E}+00$ & $8.97 \mathrm{E}+01$ & $5.38 \mathrm{E}+01$ \\
\hline
\end{tabular}


Table L.17 Absorbed Dose to Organs for an Adipose Female Healthcare Provider from Reference Female Patient for $37 \mathrm{GBq} / \mathrm{m}^{2}$ Surface Contamination (mGy/hr)

\begin{tabular}{|l|ccccc|}
\hline Organ & ${ }^{\mathbf{6 0}} \mathbf{C o}$ & ${ }^{\mathbf{1 9 2}} \mathbf{I r}$ & ${ }^{\mathbf{2 4 1}} \mathbf{A m}$ & ${ }^{\mathbf{1 3 7}} \mathbf{C s}$ & ${ }^{131} \mathbf{I}$ \\
\hline \hline Gonads & $1.01 \mathrm{E}+01$ & $3.66 \mathrm{E}+00$ & $4.63 \mathrm{E}-02$ & $2.34 \mathrm{E}+00$ & $1.28 \mathrm{E}+00$ \\
Stomach & $3.92 \mathrm{E}+01$ & $1.71 \mathrm{E}+01$ & $4.72 \mathrm{E}-01$ & $1.01 \mathrm{E}+01$ & $6.26 \mathrm{E}+00$ \\
Colon Wall & $3.78 \mathrm{E}+01$ & $1.41 \mathrm{E}+01$ & $2.58 \mathrm{E}-01$ & $9.04 \mathrm{E}+00$ & $5.28 \mathrm{E}+00$ \\
Bladder & $6.58 \mathrm{E}+01$ & $2.39 \mathrm{E}+01$ & $4.17 \mathrm{E}-01$ & $1.54 \mathrm{E}+01$ & $8.86 \mathrm{E}+00$ \\
Lungs & $1.13 \mathrm{E}+01$ & $4.54 \mathrm{E}+00$ & $1.04 \mathrm{E}-01$ & $2.81 \mathrm{E}+00$ & $1.67 \mathrm{E}+00$ \\
Bone & $1.40 \mathrm{E}+01$ & $5.75 \mathrm{E}+00$ & $2.34 \mathrm{E}-01$ & $3.39 \mathrm{E}+00$ & $2.06 \mathrm{E}+00$ \\
Liver & $1.42 \mathrm{E}+01$ & $5.96 \mathrm{E}+00$ & $1.47 \mathrm{E}-01$ & $3.59 \mathrm{E}+00$ & $2.18 \mathrm{E}+00$ \\
Thyroid & $1.40 \mathrm{E}+01$ & $5.34 \mathrm{E}+00$ & $1.68 \mathrm{E}-01$ & $3.37 \mathrm{E}+00$ & $2.01 \mathrm{E}+00$ \\
Esophagus & $9.04 \mathrm{E}+00$ & $3.43 \mathrm{E}+00$ & $5.05 \mathrm{E}-02$ & $2.23 \mathrm{E}+00$ & $1.29 \mathrm{E}+00$ \\
Skin & $1.57 \mathrm{E}+01$ & $6.63 \mathrm{E}+00$ & $6.69 \mathrm{E}-01$ & $4.11 \mathrm{E}+00$ & $2.46 \mathrm{E}+00$ \\
Other & $1.10 \mathrm{E}+01$ & $4.05 \mathrm{E}+00$ & $7.81 \mathrm{E}-02$ & $2.62 \mathrm{E}+00$ & $1.56 \mathrm{E}+00$ \\
Breasts & $5.26 \mathrm{E}+01$ & $2.38 \mathrm{E}+01$ & $1.30 \mathrm{E}+00$ & $1.40 \mathrm{E}+01$ & $8.76 \mathrm{E}+00$ \\
\hline Total & $2.95 \mathrm{E}+02$ & $1.18 \mathrm{E}+02$ & $3.95 \mathrm{E}+00$ & $7.30 \mathrm{E}+01$ & $4.37 \mathrm{E}+01$ \\
\hline
\end{tabular}

Table L.18 Absorbed Dose to Organs for an Adipose Female Healthcare Provider from Adipose Male Patient for $37 \mathrm{GBq} / \mathrm{m}^{2}$ Surface Contamination $(\mathrm{mGy} / \mathrm{hr}$ )

\begin{tabular}{|l|ccccc|}
\hline Organ & ${ }^{\mathbf{6 0}} \mathbf{C o}$ & ${ }^{\mathbf{1 9 2}} \mathbf{I r}$ & ${ }^{\mathbf{2 4 1}} \mathbf{A m}$ & ${ }^{\mathbf{1 3 7}} \mathbf{C s}$ & ${ }^{\mathbf{1 3 1}} \mathbf{I}$ \\
\hline \hline Gonads & $1.47 \mathrm{E}+01$ & $5.01 \mathrm{E}+00$ & $6.35 \mathrm{E}-02$ & $3.34 \mathrm{E}+00$ & $1.89 \mathrm{E}+00$ \\
Stomach & $4.76 \mathrm{E}+01$ & $2.04 \mathrm{E}+01$ & $5.24 \mathrm{E}-01$ & $1.21 \mathrm{E}+01$ & $7.36 \mathrm{E}+00$ \\
Colon Wall & $4.84 \mathrm{E}+01$ & $1.79 \mathrm{E}+01$ & $3.18 \mathrm{E}-01$ & $1.15 \mathrm{E}+01$ & $6.61 \mathrm{E}+00$ \\
Bladder & $9.07 \mathrm{E}+01$ & $3.11 \mathrm{E}+01$ & $5.23 \mathrm{E}-01$ & $2.07 \mathrm{E}+01$ & $1.17 \mathrm{E}+01$ \\
Lungs & $1.44 \mathrm{E}+01$ & $5.59 \mathrm{E}+00$ & $1.27 \mathrm{E}-01$ & $3.50 \mathrm{E}+00$ & $2.07 \mathrm{E}+00$ \\
Bone & $1.86 \mathrm{E}+01$ & $7.48 \mathrm{E}+00$ & $3.01 \mathrm{E}-01$ & $4.45 \mathrm{E}+00$ & $2.69 \mathrm{E}+00$ \\
Liver & $1.69 \mathrm{E}+01$ & $6.85 \mathrm{E}+00$ & $1.62 \mathrm{E}-01$ & $4.23 \mathrm{E}+00$ & $2.54 \mathrm{E}+00$ \\
Thyroid & $1.82 \mathrm{E}+01$ & $6.88 \mathrm{E}+00$ & $1.97 \mathrm{E}-01$ & $4.55 \mathrm{E}+00$ & $2.70 \mathrm{E}+00$ \\
Esophagus & $1.23 \mathrm{E}+01$ & $4.09 \mathrm{E}+00$ & $5.88 \mathrm{E}-02$ & $2.73 \mathrm{E}+00$ & $1.49 \mathrm{E}+00$ \\
Skin & $1.99 \mathrm{E}+01$ & $8.00 \mathrm{E}+00$ & $7.35 \mathrm{E}-01$ & $5.03 \mathrm{E}+00$ & $2.98 \mathrm{E}+00$ \\
Other & $1.35 \mathrm{E}+01$ & $5.05 \mathrm{E}+00$ & $9.65 \mathrm{E}-02$ & $3.35 \mathrm{E}+00$ & $1.89 \mathrm{E}+00$ \\
Breasts & $6.52 \mathrm{E}+01$ & $2.84 \mathrm{E}+01$ & $1.46 \mathrm{E}+00$ & $1.70 \mathrm{E}+01$ & $1.04 \mathrm{E}+01$ \\
\hline Total & $3.80 \mathrm{E}+02$ & $1.47 \mathrm{E}+02$ & $4.57 \mathrm{E}+00$ & $9.25 \mathrm{E}+01$ & $5.44 \mathrm{E}+01$ \\
\hline
\end{tabular}


Table L.19 Absorbed Dose to Organs for an Adipose Female Healthcare Provider from Adipose Female Patient for $37 \mathrm{GBq} / \mathrm{m}^{2}$ Surface Contamination $(\mathrm{mGy} / \mathrm{hr})$

\begin{tabular}{|l|ccccc|}
\hline Organ & ${ }^{\mathbf{6 0}} \mathbf{C o}$ & ${ }^{\mathbf{1 9 2}} \mathbf{I r}$ & ${ }^{\mathbf{2 4 1}} \mathbf{A m}$ & ${ }^{\mathbf{1 3 7}} \mathbf{C s}$ & ${ }^{\mathbf{1 3 1}} \mathbf{I}$ \\
\hline \hline Gonads & $1.38 \mathrm{E}+01$ & $4.47 \mathrm{E}+00$ & $8.09 \mathrm{E}-02$ & $3.18 \mathrm{E}+00$ & $1.79 \mathrm{E}+00$ \\
Stomach & $4.73 \mathrm{E}+01$ & $2.09 \mathrm{E}+01$ & $5.73 \mathrm{E}-01$ & $1.23 \mathrm{E}+01$ & $7.59 \mathrm{E}+00$ \\
Colon Wall & $4.58 \mathrm{E}+01$ & $1.71 \mathrm{E}+01$ & $3.07 \mathrm{E}-01$ & $1.09 \mathrm{E}+01$ & $6.43 \mathrm{E}+00$ \\
Bladder & $7.60 \mathrm{E}+01$ & $2.78 \mathrm{E}+01$ & $4.95 \mathrm{E}-01$ & $1.80 \mathrm{E}+01$ & $1.04 \mathrm{E}+01$ \\
Lungs & $1.38 \mathrm{E}+01$ & $5.53 \mathrm{E}+00$ & $1.31 \mathrm{E}-01$ & $3.39 \mathrm{E}+00$ & $2.02 \mathrm{E}+00$ \\
Bone & $1.69 \mathrm{E}+01$ & $6.93 \mathrm{E}+00$ & $2.87 \mathrm{E}-01$ & $4.09 \mathrm{E}+00$ & $2.48 \mathrm{E}+00$ \\
Liver & $1.71 \mathrm{E}+01$ & $7.18 \mathrm{E}+00$ & $1.77 \mathrm{E}-01$ & $4.35 \mathrm{E}+00$ & $2.65 \mathrm{E}+00$ \\
Thyroid & $1.63 \mathrm{E}+01$ & $6.96 \mathrm{E}+00$ & $2.05 \mathrm{E}-01$ & $4.50 \mathrm{E}+00$ & $2.56 \mathrm{E}+00$ \\
Esophagus & $1.16 \mathrm{E}+01$ & $3.99 \mathrm{E}+00$ & $6.65 \mathrm{E}-02$ & $2.66 \mathrm{E}+00$ & $1.56 \mathrm{E}+00$ \\
Skin & $1.91 \mathrm{E}+01$ & $7.98 \mathrm{E}+00$ & $7.93 \mathrm{E}-01$ & $4.93 \mathrm{E}+00$ & $2.96 \mathrm{E}+00$ \\
Other & $1.38 \mathrm{E}+01$ & $4.77 \mathrm{E}+00$ & $9.97 \mathrm{E}-02$ & $3.12 \mathrm{E}+00$ & $1.85 \mathrm{E}+00$ \\
Breasts & $6.40 \mathrm{E}+01$ & $2.89 \mathrm{E}+01$ & $1.55 \mathrm{E}+00$ & $1.69 \mathrm{E}+01$ & $1.06 \mathrm{E}+01$ \\
\hline Total & $3.55 \mathrm{E}+02$ & $1.42 \mathrm{E}+02$ & $4.77 \mathrm{E}+00$ & $8.83 \mathrm{E}+01$ & $5.29 \mathrm{E}+01$ \\
\hline
\end{tabular}

Table L.20 Absorbed Dose to Organs for an Adipose Female Healthcare Provider from Postmenopausal Adipose Female Patient for $37 \mathrm{GBq} / \mathrm{m}^{2}$ Surface Contamination (mGy/hr)

\begin{tabular}{|l|ccccc|}
\hline Organ & ${ }^{\mathbf{6 0}} \mathbf{C o}$ & ${ }^{\mathbf{1 9 2}} \mathbf{I r}$ & ${ }^{\mathbf{2 4 1}} \mathbf{A m}$ & ${ }^{\mathbf{1 3 7}} \mathbf{C s}$ & ${ }^{\mathbf{1 3 1}} \mathbf{I}$ \\
\hline \hline Gonads & $1.30 \mathrm{E}+01$ & $4.32 \mathrm{E}+00$ & $6.05 \mathrm{E}-02$ & $2.92 \mathrm{E}+00$ & $1.60 \mathrm{E}+00$ \\
Stomach & $4.47 \mathrm{E}+01$ & $1.96 \mathrm{E}+01$ & $5.24 \mathrm{E}-01$ & $1.16 \mathrm{E}+01$ & $7.16 \mathrm{E}+00$ \\
Colon Wall & $4.48 \mathrm{E}+01$ & $1.66 \mathrm{E}+01$ & $3.01 \mathrm{E}-01$ & $1.08 \mathrm{E}+01$ & $6.25 \mathrm{E}+00$ \\
Bladder & $8.08 \mathrm{E}+01$ & $2.85 \mathrm{E}+01$ & $4.85 \mathrm{E}-01$ & $1.88 \mathrm{E}+01$ & $1.09 \mathrm{E}+01$ \\
Lungs & $1.34 \mathrm{E}+01$ & $5.24 \mathrm{E}+00$ & $1.18 \mathrm{E}-01$ & $3.30 \mathrm{E}+00$ & $1.94 \mathrm{E}+00$ \\
Bone & $1.69 \mathrm{E}+01$ & $6.85 \mathrm{E}+00$ & $2.80 \mathrm{E}-01$ & $4.07 \mathrm{E}+00$ & $2.46 \mathrm{E}+00$ \\
Liver & $1.64 \mathrm{E}+01$ & $6.77 \mathrm{E}+00$ & $1.66 \mathrm{E}-01$ & $4.12 \mathrm{E}+00$ & $2.49 \mathrm{E}+00$ \\
Thyroid & $1.59 \mathrm{E}+01$ & $6.49 \mathrm{E}+00$ & $2.10 \mathrm{E}-01$ & $4.03 \mathrm{E}+00$ & $2.55 \mathrm{E}+00$ \\
Esophagus & $1.14 \mathrm{E}+01$ & $3.89 \mathrm{E}+00$ & $6.04 \mathrm{E}-02$ & $2.59 \mathrm{E}+00$ & $1.56 \mathrm{E}+00$ \\
Skin & $1.85 \mathrm{E}+01$ & $7.61 \mathrm{E}+00$ & $7.30 \mathrm{E}-01$ & $4.75 \mathrm{E}+00$ & $2.83 \mathrm{E}+00$ \\
Other & $1.26 \mathrm{E}+01$ & $4.85 \mathrm{E}+00$ & $9.27 \mathrm{E}-02$ & $3.20 \mathrm{E}+00$ & $1.79 \mathrm{E}+00$ \\
Breasts & $6.10 \mathrm{E}+01$ & $2.71 \mathrm{E}+01$ & $1.44 \mathrm{E}+00$ & $1.60 \mathrm{E}+01$ & $9.97 \mathrm{E}+00$ \\
\hline Total & $3.50 \mathrm{E}+02$ & $1.38 \mathrm{E}+02$ & $4.46 \mathrm{E}+00$ & $8.61 \mathrm{E}+01$ & $5.15 \mathrm{E}+01$ \\
\hline
\end{tabular}


Table L.21 Absorbed Dose to Organs for a Postmenopausal Adipose Female Healthcare Provider from Reference Male Patient for $37 \mathrm{GBq} / \mathrm{m}^{2}$ Surface Contamination $(\mathrm{mGy} / \mathrm{hr}$ )

\begin{tabular}{|l|ccccc|}
\hline Organ & ${ }^{\mathbf{6 0}} \mathbf{C o}$ & ${ }^{\mathbf{1 9 2}} \mathbf{I r}$ & ${ }^{\mathbf{2 4 1}} \mathbf{A m}$ & ${ }^{\mathbf{1 3 7}} \mathbf{C s}$ & ${ }^{\mathbf{1 3 1}} \mathbf{I}$ \\
\hline \hline Gonads & $2.50 \mathrm{E}+01$ & $9.16 \mathrm{E}+00$ & $1.35 \mathrm{E}-01$ & $6.05 \mathrm{E}+00$ & $3.32 \mathrm{E}+00$ \\
Stomach & $4.23 \mathrm{E}+01$ & $1.79 \mathrm{E}+01$ & $4.47 \mathrm{E}-01$ & $1.07 \mathrm{E}+01$ & $6.60 \mathrm{E}+00$ \\
Colon Wall & $4.27 \mathrm{E}+01$ & $1.60 \mathrm{E}+01$ & $2.61 \mathrm{E}-01$ & $1.01 \mathrm{E}+01$ & $5.90 \mathrm{E}+00$ \\
Bladder & $8.08 \mathrm{E}+01$ & $2.87 \mathrm{E}+01$ & $4.82 \mathrm{E}-01$ & $1.88 \mathrm{E}+01$ & $1.08 \mathrm{E}+01$ \\
Lungs & $1.29 \mathrm{E}+01$ & $5.10 \mathrm{E}+00$ & $1.14 \mathrm{E}-01$ & $3.17 \mathrm{E}+00$ & $1.88 \mathrm{E}+00$ \\
Bone & $1.62 \mathrm{E}+01$ & $6.72 \mathrm{E}+00$ & $2.51 \mathrm{E}-01$ & $3.92 \mathrm{E}+00$ & $2.40 \mathrm{E}+00$ \\
Liver & $1.66 \mathrm{E}+01$ & $6.87 \mathrm{E}+00$ & $1.58 \mathrm{E}-01$ & $4.17 \mathrm{E}+00$ & $2.53 \mathrm{E}+00$ \\
Thyroid & $2.13 \mathrm{E}+01$ & $8.47 \mathrm{E}+00$ & $2.12 \mathrm{E}-01$ & $5.42 \mathrm{E}+00$ & $3.23 \mathrm{E}+00$ \\
Esophagus & $9.82 \mathrm{E}+00$ & $3.54 \mathrm{E}+00$ & $5.47 \mathrm{E}-02$ & $2.37 \mathrm{E}+00$ & $1.33 \mathrm{E}+00$ \\
Skin & $1.75 \mathrm{E}+01$ & $7.44 \mathrm{E}+00$ & $7.98 \mathrm{E}-01$ & $4.58 \mathrm{E}+00$ & $2.75 \mathrm{E}+00$ \\
Other & $1.27 \mathrm{E}+01$ & $4.68 \mathrm{E}+00$ & $8.41 \mathrm{E}-02$ & $2.96 \mathrm{E}+00$ & $1.70 \mathrm{E}+00$ \\
Breasts & $5.78 \mathrm{E}+01$ & $2.65 \mathrm{E}+01$ & $1.50 \mathrm{E}+00$ & $1.54 \mathrm{E}+01$ & $9.72 \mathrm{E}+00$ \\
\hline Total & $3.56 \mathrm{E}+02$ & $1.41 \mathrm{E}+02$ & $4.50 \mathrm{E}+00$ & $8.78 \mathrm{E}+01$ & $5.22 \mathrm{E}+01$ \\
\hline
\end{tabular}

Table L.22 Absorbed Dose to Organs for a Postmenopausal Adipose Female Healthcare Provider from Reference Female Patient for $37 \mathrm{GBq} / \mathrm{m}^{2}$ Surface Contamination (mGy/hr)

\begin{tabular}{|l|ccccc|}
\hline Organ & ${ }^{\mathbf{6 0}} \mathbf{C o}$ & ${ }^{\mathbf{1 9 2}} \mathbf{I r}$ & ${ }^{\mathbf{2 4 1}} \mathbf{A m}$ & ${ }^{\mathbf{1 3 7}} \mathbf{C s}$ & ${ }^{131} \mathbf{I}$ \\
\hline \hline Gonads & $2.11 \mathrm{E}+01$ & $6.68 \mathrm{E}+00$ & $9.99 \mathrm{E}-02$ & $4.64 \mathrm{E}+00$ & $2.89 \mathrm{E}+00$ \\
Stomach & $3.63 \mathrm{E}+01$ & $1.56 \mathrm{E}+01$ & $3.77 \mathrm{E}-01$ & $9.29 \mathrm{E}+00$ & $5.72 \mathrm{E}+00$ \\
Colon Wall & $3.56 \mathrm{E}+01$ & $1.27 \mathrm{E}+01$ & $2.05 \mathrm{E}-01$ & $8.28 \mathrm{E}+00$ & $4.75 \mathrm{E}+00$ \\
Bladder & $6.14 \mathrm{E}+01$ & $2.11 \mathrm{E}+01$ & $3.30 \mathrm{E}-01$ & $1.42 \mathrm{E}+01$ & $7.91 \mathrm{E}+00$ \\
Lungs & $1.10 \mathrm{E}+01$ & $4.31 \mathrm{E}+00$ & $9.38 \mathrm{E}-02$ & $2.72 \mathrm{E}+00$ & $1.59 \mathrm{E}+00$ \\
Bone & $1.35 \mathrm{E}+01$ & $5.56 \mathrm{E}+00$ & $2.07 \mathrm{E}-01$ & $3.27 \mathrm{E}+00$ & $1.99 \mathrm{E}+00$ \\
Liver & $1.33 \mathrm{E}+01$ & $5.53 \mathrm{E}+00$ & $1.25 \mathrm{E}-01$ & $3.37 \mathrm{E}+00$ & $2.03 \mathrm{E}+00$ \\
Thyroid & $1.98 \mathrm{E}+01$ & $7.33 \mathrm{E}+00$ & $2.05 \mathrm{E}-01$ & $4.77 \mathrm{E}+00$ & $2.76 \mathrm{E}+00$ \\
Esophagus & $8.97 \mathrm{E}+00$ & $3.41 \mathrm{E}+00$ & $4.63 \mathrm{E}-02$ & $2.18 \mathrm{E}+00$ & $1.23 \mathrm{E}+00$ \\
Skin & $1.44 \mathrm{E}+01$ & $6.02 \mathrm{E}+00$ & $6.17 \mathrm{E}-01$ & $3.74 \mathrm{E}+00$ & $2.24 \mathrm{E}+00$ \\
Other & $1.13 \mathrm{E}+01$ & $3.96 \mathrm{E}+00$ & $7.37 \mathrm{E}-02$ & $2.59 \mathrm{E}+00$ & $1.49 \mathrm{E}+00$ \\
Breasts & $4.90 \mathrm{E}+01$ & $2.22 \mathrm{E}+01$ & $1.23 \mathrm{E}+00$ & $1.30 \mathrm{E}+01$ & $8.16 \mathrm{E}+00$ \\
\hline Total & $2.96 \mathrm{E}+02$ & $1.14 \mathrm{E}+02$ & $3.61 \mathrm{E}+00$ & $7.21 \mathrm{E}+01$ & $4.28 \mathrm{E}+01$ \\
\hline
\end{tabular}


Table L.23 Absorbed Dose to Organs for a Postmenopausal Adipose Female Healthcare Provider from Adipose Male Patient for $37 \mathrm{GBq} / \mathrm{m}^{2}$ Surface Contamination (mGy/hr)

\begin{tabular}{|l|ccccc|}
\hline Organ & ${ }^{60} \mathbf{C o}$ & ${ }^{192} \mathbf{I r}$ & ${ }^{\mathbf{2 4 1}} \mathbf{A m}$ & ${ }^{\mathbf{1 3 7}} \mathbf{C s}$ & ${ }^{131} \mathbf{I}$ \\
\hline \hline Gonads & $2.76 \mathrm{E}+01$ & $9.50 \mathrm{E}+00$ & $1.29 \mathrm{E}-01$ & $6.03 \mathrm{E}+00$ & $3.26 \mathrm{E}+00$ \\
Stomach & $4.46 \mathrm{E}+01$ & $1.87 \mathrm{E}+01$ & $4.47 \mathrm{E}-01$ & $1.13 \mathrm{E}+01$ & $6.94 \mathrm{E}+00$ \\
Colon Wall & $4.53 \mathrm{E}+01$ & $1.62 \mathrm{E}+01$ & $2.67 \mathrm{E}-01$ & $1.07 \mathrm{E}+01$ & $6.04 \mathrm{E}+00$ \\
Bladder & $8.25 \mathrm{E}+01$ & $2.81 \mathrm{E}+01$ & $4.33 \mathrm{E}-01$ & $1.91 \mathrm{E}+01$ & $1.06 \mathrm{E}+01$ \\
Lungs & $1.39 \mathrm{E}+01$ & $5.34 \mathrm{E}+00$ & $1.13 \mathrm{E}-01$ & $3.36 \mathrm{E}+00$ & $1.97 \mathrm{E}+00$ \\
Bone & $1.81 \mathrm{E}+01$ & $7.29 \mathrm{E}+00$ & $2.68 \mathrm{E}-01$ & $4.31 \mathrm{E}+00$ & $2.62 \mathrm{E}+00$ \\
Liver & $1.61 \mathrm{E}+01$ & $6.36 \mathrm{E}+00$ & $1.41 \mathrm{E}-01$ & $3.96 \mathrm{E}+00$ & $2.36 \mathrm{E}+00$ \\
Thyroid & $2.66 \mathrm{E}+01$ & $9.87 \mathrm{E}+00$ & $2.61 \mathrm{E}-01$ & $6.20 \mathrm{E}+00$ & $3.77 \mathrm{E}+00$ \\
Esophagus & $1.15 \mathrm{E}+01$ & $3.99 \mathrm{E}+00$ & $4.99 \mathrm{E}-02$ & $2.74 \mathrm{E}+00$ & $1.46 \mathrm{E}+00$ \\
Skin & $1.81 \mathrm{E}+01$ & $7.21 \mathrm{E}+00$ & $6.69 \mathrm{E}-01$ & $4.55 \mathrm{E}+00$ & $2.69 \mathrm{E}+00$ \\
Other & $1.29 \mathrm{E}+01$ & $4.83 \mathrm{E}+00$ & $8.28 \mathrm{E}-02$ & $3.07 \mathrm{E}+00$ & $1.78 \mathrm{E}+00$ \\
Breasts & $6.06 \mathrm{E}+01$ & $2.64 \mathrm{E}+01$ & $1.39 \mathrm{E}+00$ & $1.58 \mathrm{E}+01$ & $9.69 \mathrm{E}+00$ \\
\hline Total & $3.78 \mathrm{E}+02$ & $1.44 \mathrm{E}+02$ & $4.25 \mathrm{E}+00$ & $9.11 \mathrm{E}+01$ & $5.32 \mathrm{E}+01$ \\
\hline
\end{tabular}

Table L.24 Absorbed Dose to Organs for a Postmenopausal Adipose Female Healthcare Provider from Adipose Female Patient for $37 \mathrm{GBq} / \mathrm{m}^{2}$ Surface Contamination $(\mathrm{mGy} / \mathrm{hr})$

\begin{tabular}{|l|ccccc|}
\hline Organ & ${ }^{60} \mathbf{C o}$ & ${ }^{\mathbf{1 9 2}} \mathbf{I r}$ & ${ }^{241} \mathbf{A m}$ & ${ }^{\mathbf{1 3 7}} \mathbf{C s}$ & ${ }^{\mathbf{1 3 1}} \mathbf{I}$ \\
\hline \hline Gonads & $2.53 \mathrm{E}+01$ & $8.80 \mathrm{E}+00$ & $1.18 \mathrm{E}-01$ & $5.55 \mathrm{E}+00$ & $3.26 \mathrm{E}+00$ \\
Stomach & $4.47 \mathrm{E}+01$ & $1.93 \mathrm{E}+01$ & $4.96 \mathrm{E}-01$ & $1.15 \mathrm{E}+01$ & $7.03 \mathrm{E}+00$ \\
Colon Wall & $4.28 \mathrm{E}+01$ & $1.57 \mathrm{E}+01$ & $2.61 \mathrm{E}-01$ & $1.02 \mathrm{E}+01$ & $5.92 \mathrm{E}+00$ \\
Bladder & $7.21 \mathrm{E}+01$ & $2.50 \mathrm{E}+01$ & $3.99 \mathrm{E}-01$ & $1.67 \mathrm{E}+01$ & $9.36 \mathrm{E}+00$ \\
Lungs & $1.33 \mathrm{E}+01$ & $5.24 \mathrm{E}+00$ & $1.15 \mathrm{E}-01$ & $3.26 \mathrm{E}+00$ & $1.91 \mathrm{E}+00$ \\
Bone & $1.63 \mathrm{E}+01$ & $6.73 \mathrm{E}+00$ & $2.54 \mathrm{E}-01$ & $3.95 \mathrm{E}+00$ & $2.41 \mathrm{E}+00$ \\
Liver & $1.62 \mathrm{E}+01$ & $6.65 \mathrm{E}+00$ & $1.50 \mathrm{E}-01$ & $4.04 \mathrm{E}+00$ & $2.46 \mathrm{E}+00$ \\
Thyroid & $2.47 \mathrm{E}+01$ & $9.48 \mathrm{E}+00$ & $2.62 \mathrm{E}-01$ & $6.05 \mathrm{E}+00$ & $3.50 \mathrm{E}+00$ \\
Esophagus & $1.03 \mathrm{E}+01$ & $3.64 \mathrm{E}+00$ & $6.12 \mathrm{E}-02$ & $2.53 \mathrm{E}+00$ & $1.42 \mathrm{E}+00$ \\
Skin & $1.73 \mathrm{E}+01$ & $7.24 \mathrm{E}+00$ & $7.28 \mathrm{E}-01$ & $4.48 \mathrm{E}+00$ & $2.69 \mathrm{E}+00$ \\
Other & $1.26 \mathrm{E}+01$ & $4.70 \mathrm{E}+00$ & $7.91 \mathrm{E}-02$ & $2.95 \mathrm{E}+00$ & $1.72 \mathrm{E}+00$ \\
Breasts & $5.95 \mathrm{E}+01$ & $2.68 \mathrm{E}+01$ & $1.47 \mathrm{E}+00$ & $1.58 \mathrm{E}+01$ & $9.86 \mathrm{E}+00$ \\
\hline Total & $3.55 \mathrm{E}+02$ & $1.39 \mathrm{E}+02$ & $4.39 \mathrm{E}+00$ & $8.68 \mathrm{E}+01$ & $5.15 \mathrm{E}+01$ \\
\hline
\end{tabular}


Table L.25 Absorbed Dose to Organs for a Postmenopausal Adipose Female Healthcare Provider from Postmenopausal Adipose Female Patient for $37 \mathrm{GBq} / \mathrm{m}^{2}$ Surface Contamination (mGy/hr)

\begin{tabular}{|l|ccccc|}
\hline Organ & ${ }^{\mathbf{6 0}} \mathbf{C o}$ & ${ }^{\mathbf{1 9 2}} \mathbf{I r}$ & ${ }^{\mathbf{2 4 1}} \mathbf{A m}$ & ${ }^{\mathbf{1 3 7}} \mathbf{C s}$ & ${ }^{\mathbf{1 3 1}} \mathbf{I}$ \\
\hline \hline Gonads & $2.69 \mathrm{E}+01$ & $7.44 \mathrm{E}+00$ & $1.43 \mathrm{E}-01$ & $5.72 \mathrm{E}+00$ & $3.10 \mathrm{E}+00$ \\
Stomach & $4.24 \mathrm{E}+01$ & $1.81 \mathrm{E}+01$ & $4.56 \mathrm{E}-01$ & $1.08 \mathrm{E}+01$ & $6.62 \mathrm{E}+00$ \\
Colon Wall & $4.32 \mathrm{E}+01$ & $1.52 \mathrm{E}+01$ & $2.44 \mathrm{E}-01$ & $9.92 \mathrm{E}+00$ & $5.67 \mathrm{E}+00$ \\
Bladder & $7.37 \mathrm{E}+01$ & $2.46 \mathrm{E}+01$ & $3.94 \mathrm{E}-01$ & $1.70 \mathrm{E}+01$ & $9.61 \mathrm{E}+00$ \\
Lungs & $1.29 \mathrm{E}+01$ & $5.03 \mathrm{E}+00$ & $1.08 \mathrm{E}-01$ & $3.14 \mathrm{E}+00$ & $1.84 \mathrm{E}+00$ \\
Bone & $1.63 \mathrm{E}+01$ & $6.68 \mathrm{E}+00$ & $2.49 \mathrm{E}-01$ & $3.93 \mathrm{E}+00$ & $2.38 \mathrm{E}+00$ \\
Liver & $1.54 \mathrm{E}+01$ & $6.22 \mathrm{E}+00$ & $1.41 \mathrm{E}-01$ & $3.84 \mathrm{E}+00$ & $2.31 \mathrm{E}+00$ \\
Thyroid & $2.28 \mathrm{E}+01$ & $9.16 \mathrm{E}+00$ & $2.44 \mathrm{E}-01$ & $5.84 \mathrm{E}+00$ & $3.45 \mathrm{E}+00$ \\
Esophagus & $1.11 \mathrm{E}+01$ & $3.61 \mathrm{E}+00$ & $5.72 \mathrm{E}-02$ & $2.59 \mathrm{E}+00$ & $1.42 \mathrm{E}+00$ \\
Skin & $1.68 \mathrm{E}+01$ & $6.96 \mathrm{E}+00$ & $6.66 \mathrm{E}-01$ & $4.32 \mathrm{E}+00$ & $2.57 \mathrm{E}+00$ \\
Other & $1.30 \mathrm{E}+01$ & $4.61 \mathrm{E}+00$ & $8.83 \mathrm{E}-02$ & $3.09 \mathrm{E}+00$ & $1.79 \mathrm{E}+00$ \\
Breasts & $5.66 \mathrm{E}+01$ & $2.54 \mathrm{E}+01$ & $1.36 \mathrm{E}+00$ & $1.50 \mathrm{E}+01$ & $9.28 \mathrm{E}+00$ \\
\hline Total & $3.51 \mathrm{E}+02$ & $1.33 \mathrm{E}+02$ & $4.15 \mathrm{E}+00$ & $8.51 \mathrm{E}+01$ & $5.00 \mathrm{E}+01$ \\
\hline
\end{tabular}




\section{APPENDIX M}

\section{ABSORBED DOSE TO ORGANS FOR HEALTHCARE PROVIDER DUE TO INTERNALLY CONTAMINATED PATIENT}

Table M.1 Absorbed Dose to Organs for a Reference Male Healthcare Provider from Reference

Male Patient for Internal Contamination $(\mu \mathrm{Gy} / \mathrm{hr}) / \mathrm{ALI}$

\begin{tabular}{|c|cccccccc|}
\hline Organ & ${ }^{\mathbf{6 0}} \mathbf{C o}(\mathbf{s})$ & ${ }^{\mathbf{6 0}} \mathbf{C o}(\mathbf{m})$ & ${ }^{\mathbf{1 9 2}} \mathbf{I r}(\mathbf{s})$ & ${ }^{\mathbf{1 9 2}} \mathbf{I r}(\mathbf{m})$ & ${ }^{\mathbf{1 9 2}} \mathbf{I r}(\mathbf{f})$ & ${ }^{\mathbf{2 4 1}} \mathbf{A m}$ & ${ }^{\mathbf{1 3 7}} \mathbf{C s}$ & ${ }^{\mathbf{1 3 1}} \mathbf{I}$ \\
\hline \hline Gonads & 0.151 & 0.920 & 0.414 & 0.491 & 1.250 & $5.78 \mathrm{E}-07$ & 0.389 & 0.132 \\
Stomach & 1.198 & 3.604 & 2.489 & 2.878 & 7.452 & $6.58 \mathrm{E}-06$ & 1.827 & 0.718 \\
Colon Wall & 1.526 & 4.712 & 2.974 & 3.465 & 8.498 & $6.53 \mathrm{E}-06$ & 2.320 & 0.868 \\
Bladder & 2.599 & 7.985 & 5.126 & 5.936 & 14.390 & $1.17 \mathrm{E}-05$ & 3.914 & 1.416 \\
Lungs & 0.328 & 1.003 & 0.636 & 0.775 & 1.805 & $1.86 \mathrm{E}-06$ & 0.483 & 0.193 \\
Bone & 0.380 & 1.175 & 0.758 & 0.913 & 2.231 & $3.26 \mathrm{E}-06$ & 0.568 & 0.224 \\
Liver & 0.426 & 1.330 & 0.861 & 1.044 & 2.155 & $2.50 \mathrm{E}-06$ & 0.628 & 0.252 \\
Thyroid & 0.470 & 1.409 & 0.962 & 1.175 & 2.904 & $3.42 \mathrm{E}-06$ & 0.691 & 0.276 \\
Esophagus & 0.214 & 0.667 & 0.363 & 0.437 & 0.993 & $5.95 \mathrm{E}-07$ & 0.290 & 0.108 \\
Skin & 0.237 & 0.731 & 0.433 & 0.517 & 1.250 & $1.25 \mathrm{E}-06$ & 0.357 & 0.133 \\
Other & 0.338 & 1.051 & 0.623 & 0.765 & 1.698 & $1.36 \mathrm{E}-06$ & 0.499 & 0.186 \\
\hline Total & 7.868 & 24.587 & 15.638 & 18.396 & 44.624 & $3.96 \mathrm{E}-05$ & 11.966 & 4.507 \\
\hline
\end{tabular}

Table M.2 Absorbed Dose to Organs for a Reference Male Healthcare Provider from Reference

Female Patient for Internal Contamination $(\mu \mathrm{Gy} / \mathrm{hr}) / \mathrm{ALI}$

\begin{tabular}{|c|cccccccc|}
\hline Organ & ${ }^{\mathbf{6 0}} \mathbf{C o}(\mathbf{s})$ & ${ }^{\mathbf{6 0}} \mathbf{C o}(\mathbf{m})$ & ${ }^{\mathbf{1 9 2}} \mathbf{I r}(\mathbf{s})$ & ${ }^{\mathbf{1 9 2}} \mathbf{I r}(\mathbf{m})$ & ${ }^{\mathbf{1 9 2}} \mathbf{I r}(\mathbf{f})$ & ${ }^{\mathbf{2 4 1}} \mathbf{A m}$ & ${ }^{\mathbf{1 3 7}} \mathbf{C s}$ & ${ }^{\mathbf{1 3 1}} \mathbf{I}$ \\
\hline \hline Gonads & 0.319 & 0.986 & 0.428 & 0.542 & 1.279 & $7.86 \mathrm{E}-07$ & 0.484 & 0.125 \\
Stomach & 1.284 & 3.884 & 2.486 & 3.144 & 8.068 & $7.58 \mathrm{E}-06$ & 1.904 & 0.736 \\
Colon Wall & 1.633 & 5.076 & 3.067 & 3.858 & 9.108 & $7.81 \mathrm{E}-06$ & 2.828 & 0.884 \\
Bladder & 2.780 & 8.592 & 5.236 & 6.573 & 15.489 & $1.40 \mathrm{E}-05$ & 4.871 & 1.468 \\
Lungs & 0.338 & 1.034 & 0.640 & 0.805 & 1.909 & $2.00 \mathrm{E}-06$ & 0.550 & 0.203 \\
Bone & 0.394 & 1.219 & 0.759 & 0.959 & 2.353 & $3.47 \mathrm{E}-06$ & 0.649 & 0.230 \\
Liver & 0.441 & 1.380 & 0.883 & 1.104 & 2.283 & $2.74 \mathrm{E}-06$ & 0.855 & 0.268 \\
Thyroid & 0.477 & 1.450 & 0.945 & 1.188 & 3.047 & $3.49 \mathrm{E}-06$ & 0.798 & 0.301 \\
Esophagus & 0.214 & 0.653 & 0.358 & 0.441 & 1.116 & $7.47 \mathrm{E}-07$ & 0.339 & 0.116 \\
Skin & 0.248 & 0.767 & 0.436 & 0.551 & 1.322 & $1.39 \mathrm{E}-06$ & 0.413 & 0.137 \\
Other & 0.352 & 1.053 & 0.608 & 0.779 & 1.867 & $1.58 \mathrm{E}-06$ & 0.529 & 0.195 \\
\hline Total & 8.478 & 26.093 & 15.847 & 19.943 & 47.839 & $4.56 \mathrm{E}-05$ & 14.219 & 4.662 \\
\hline
\end{tabular}


Table M.3 Absorbed Dose to Organs for a Reference Male Healthcare Provider from Adipose Male Patient for Internal Contamination $(\mu \mathrm{Gy} / \mathrm{hr}) / \mathrm{ALI}$

\begin{tabular}{|c|cccccccc|}
\hline Organ & ${ }^{\mathbf{6 0}} \mathbf{C o}(\mathbf{s})$ & ${ }^{\mathbf{6 0}} \mathbf{C o}(\mathbf{m})$ & ${ }^{\mathbf{1 9 2}} \mathbf{I r}(\mathbf{s})$ & ${ }^{\mathbf{1 9 2}} \mathbf{I r}(\mathbf{m})$ & ${ }^{\mathbf{1 9 2}} \mathbf{I r}(\mathbf{f})$ & ${ }^{{ }^{241}} \mathbf{A m}$ & ${ }^{\mathbf{1 3 7}} \mathbf{C s}$ & ${ }^{\mathbf{1 3 1}} \mathbf{I}$ \\
\hline \hline Gonads & 0.338 & 1.035 & 0.494 & 0.635 & 1.704 & $9.11 \mathrm{E}-07$ & 0.483 & 0.151 \\
Stomach & 1.112 & 3.364 & 2.043 & 2.595 & 7.673 & $4.92 \mathrm{E}-06$ & 1.887 & 0.632 \\
Colon Wall & 1.457 & 4.515 & 2.603 & 3.312 & 9.017 & $5.31 \mathrm{E}-06$ & 2.407 & 0.798 \\
Bladder & 2.481 & 7.776 & 4.684 & 5.917 & 16.089 & $1.08 \mathrm{E}-05$ & 4.134 & 1.363 \\
Lungs & 0.285 & 0.887 & 0.508 & 0.647 & 1.772 & $1.28 \mathrm{E}-06$ & 0.477 & 0.172 \\
Bone & 0.348 & 1.087 & 0.650 & 0.825 & 2.248 & $2.36 \mathrm{E}-06$ & 0.569 & 0.207 \\
Liver & 0.395 & 1.246 & 0.749 & 0.942 & 2.243 & $1.93 \mathrm{E}-06$ & 0.638 & 0.234 \\
Thyroid & 0.374 & 1.191 & 0.694 & 0.845 & 2.724 & $1.95 \mathrm{E}-06$ & 0.680 & 0.251 \\
Esophagus & 0.178 & 0.550 & 0.270 & 0.343 & 0.989 & $3.96 \mathrm{E}-07$ & 0.279 & 0.096 \\
Skin & 0.216 & 0.674 & 0.364 & 0.460 & 1.265 & $9.70 \mathrm{E}-07$ & 0.359 & 0.122 \\
Other & 0.299 & 0.909 & 0.522 & 0.666 & 1.673 & $1.02 \mathrm{E}-06$ & 0.485 & 0.164 \\
\hline Total & 7.484 & 23.235 & 13.583 & 17.187 & 47.397 & $3.19 \mathrm{E}-05$ & 12.397 & 4.188 \\
\hline
\end{tabular}

Table M.4 Absorbed Dose to Organs for a Reference Male Healthcare Provider from Adipose Female Patient for Internal Contamination $(\mu \mathrm{Gy} / \mathrm{hr}) / \mathrm{ALI}$

\begin{tabular}{|c|cccccccc|}
\hline Organ & ${ }^{\mathbf{6 0}} \mathbf{C o}(\mathbf{s})$ & ${ }^{\mathbf{6 0}} \mathbf{C o}(\mathbf{m})$ & ${ }^{\mathbf{1 9 2}} \mathbf{I r}(\mathbf{s})$ & ${ }^{\mathbf{1 9 2}} \mathbf{I r}(\mathbf{m})$ & ${ }^{\mathbf{1 9 2}} \mathbf{I r}(\mathbf{f})$ & ${ }^{\mathbf{2 4 1}} \mathbf{A m}$ & ${ }^{\mathbf{1 3 7}} \mathbf{C s}$ & ${ }^{\mathbf{1 3 1}} \mathbf{I}$ \\
\hline \hline Gonads & 0.333 & 1.046 & 0.463 & 0.589 & 1.408 & $7.93 \mathrm{E}-07$ & 0.429 & 0.139 \\
Stomach & 1.221 & 3.689 & 2.337 & 2.974 & 8.376 & $6.55 \mathrm{E}-06$ & 2.034 & 0.718 \\
Colon Wall & 1.577 & 4.898 & 2.913 & 3.666 & 9.438 & $6.97 \mathrm{E}-06$ & 2.503 & 0.873 \\
Bladder & 2.715 & 8.448 & 5.048 & 6.355 & 15.799 & $1.27 \mathrm{E}-05$ & 4.223 & 1.438 \\
Lungs & 0.307 & 0.950 & 0.562 & 0.716 & 1.898 & $1.54 \mathrm{E}-06$ & 0.494 & 0.186 \\
Bone & 0.368 & 1.148 & 0.699 & 0.884 & 2.331 & $2.74 \mathrm{E}-06$ & 0.584 & 0.219 \\
Liver & 0.421 & 1.322 & 0.826 & 1.039 & 2.344 & $2.33 \mathrm{E}-06$ & 0.661 & 0.254 \\
Thyroid & 0.419 & 1.344 & 0.776 & 0.995 & 2.906 & $2.37 \mathrm{E}-06$ & 0.715 & 0.291 \\
Esophagus & 0.194 & 0.605 & 0.317 & 0.398 & 1.078 & $5.56 \mathrm{E}-07$ & 0.297 & 0.110 \\
Skin & 0.231 & 0.722 & 0.398 & 0.504 & 1.325 & $1.16 \mathrm{E}-06$ & 0.369 & 0.130 \\
Other & 0.311 & 0.955 & 0.538 & 0.700 & 2.060 & $1.21 \mathrm{E}-06$ & 0.526 & 0.188 \\
\hline Total & 8.097 & 25.126 & 14.877 & 18.820 & 48.961 & $3.89 \mathrm{E}-05$ & 12.835 & 4.546 \\
\hline
\end{tabular}


Table M.5 Absorbed Dose to Organs for a Reference Male Healthcare Provider from Postmenopausal Adipose Female Patient for Internal Contamination ( $\mu \mathrm{Gy} / \mathrm{hr}) / \mathrm{ALI}$

\begin{tabular}{|c|cccccccc|}
\hline Organ & ${ }^{\mathbf{6 0}} \mathbf{C o}(\mathbf{s})$ & ${ }^{\mathbf{6 0}} \mathbf{C o}(\mathbf{m})$ & ${ }^{\mathbf{1 9 2}} \mathbf{I r}(\mathbf{s})$ & ${ }^{\mathbf{1 9 2}} \mathbf{I r}(\mathbf{m})$ & ${ }^{\mathbf{1 9 2}} \mathbf{I r}(\mathbf{f})$ & ${ }^{\mathbf{2 4 1}_{\mathbf{A m}}}$ & ${ }^{\mathbf{1 3 7}} \mathbf{C s}$ & ${ }^{\mathbf{1 3 1}} \mathbf{I}$ \\
\hline \hline Gonads & 0.346 & 1.058 & 0.498 & 0.631 & 2.206 & $8.89 \mathrm{E}-07$ & 0.778 & 0.140 \\
Stomach & 1.177 & 3.571 & 2.206 & 2.810 & 8.718 & $5.65 \mathrm{E}-06$ & 2.920 & 0.678 \\
Colon Wall & 1.520 & 4.729 & 2.779 & 3.507 & 12.047 & $6.08 \mathrm{E}-06$ & 3.755 & 0.830 \\
Bladder & 2.609 & 8.149 & 4.932 & 6.206 & 21.253 & $1.23 \mathrm{E}-05$ & 6.238 & 1.417 \\
Lungs & 0.299 & 0.923 & 0.537 & 0.679 & 2.144 & $1.38 \mathrm{E}-06$ & 0.731 & 0.177 \\
Bone & 0.359 & 1.115 & 0.672 & 0.851 & 2.762 & $2.47 \mathrm{E}-06$ & 0.892 & 0.211 \\
Liver & 0.405 & 1.271 & 0.783 & 0.982 & 3.383 & $2.08 \mathrm{E}-06$ & 0.961 & 0.239 \\
Thyroid & 0.391 & 1.225 & 0.737 & 0.930 & 2.932 & $2.03 \mathrm{E}-06$ & 1.026 & 0.264 \\
Esophagus & 0.191 & 0.576 & 0.298 & 0.373 & 1.146 & $4.82 \mathrm{E}-07$ & 0.446 & 0.102 \\
Skin & 0.222 & 0.692 & 0.378 & 0.479 & 1.600 & $1.03 \mathrm{E}-06$ & 0.556 & 0.125 \\
Other & 0.303 & 0.930 & 0.508 & 0.658 & 2.167 & $1.10 \mathrm{E}-06$ & 0.775 & 0.172 \\
\hline Total & 7.823 & 24.238 & 14.327 & 18.107 & 60.356 & $3.55 \mathrm{E}-05$ & 19.077 & 4.354 \\
\hline
\end{tabular}

Table M.6 Absorbed Dose to Organs for a Reference Female Healthcare Provider from Reference Male Patient for Internal Contamination ( $\mu \mathrm{Gy} / \mathrm{hr}) / \mathrm{ALI}$

\begin{tabular}{|c|cccccccc|}
\hline Organ & ${ }^{\mathbf{6 0}} \mathbf{C o}(\mathbf{s})$ & ${ }^{\mathbf{6 0}} \mathbf{C o}(\mathbf{m})$ & ${ }^{\mathbf{1 9 2}} \mathbf{I r}(\mathbf{s})$ & ${ }^{\mathbf{1 9 2}} \mathbf{I r}(\mathbf{m})$ & ${ }^{\mathbf{1 9 2}} \mathbf{I r}(\mathbf{f})$ & ${ }^{\mathbf{2 4 1}} \mathbf{A m}$ & ${ }^{\mathbf{1 3 7}} \mathbf{C s}$ & ${ }^{\mathbf{1 3 1}} \mathbf{I}$ \\
\hline \hline Gonads & 0.378 & 1.150 & 0.715 & 0.832 & 2.127 & $1.16 \mathrm{E}-06$ & 0.568 & 1.991 \\
Stomach & 1.117 & 3.355 & 2.298 & 2.637 & 6.853 & $6.17 \mathrm{E}-06$ & 1.708 & 6.631 \\
Colon Wall & 1.289 & 4.027 & 2.500 & 2.925 & 7.311 & $5.61 \mathrm{E}-06$ & 2.001 & 7.431 \\
Bladder & 2.572 & 7.921 & 4.983 & 5.778 & 14.065 & $1.11 \mathrm{E}-05$ & 3.803 & 13.815 \\
Lungs & 0.336 & 1.029 & 0.634 & 0.765 & 1.791 & $1.70 \mathrm{E}-06$ & 0.498 & 1.948 \\
Bone & 0.404 & 1.246 & 0.799 & 0.961 & 2.353 & $3.36 \mathrm{E}-06$ & 0.600 & 2.361 \\
Liver & 0.448 & 1.400 & 0.909 & 1.097 & 2.304 & $2.60 \mathrm{E}-06$ & 0.665 & 2.662 \\
Thyroid & 0.418 & 1.267 & 0.850 & 1.084 & 2.625 & $3.22 \mathrm{E}-06$ & 0.627 & 2.710 \\
Esophagus & 0.268 & 0.824 & 0.450 & 0.545 & 1.338 & $8.06 \mathrm{E}-07$ & 0.371 & 1.378 \\
Skin & 0.359 & 1.105 & 0.646 & 0.774 & 1.871 & $1.79 \mathrm{E}-06$ & 0.534 & 1.989 \\
Other & 0.360 & 1.069 & 0.624 & 0.756 & 1.925 & $1.47 \mathrm{E}-06$ & 0.513 & 2.017 \\
Breast & 1.324 & 4.045 & 2.775 & 3.366 & 7.594 & $1.01 \mathrm{E}-05$ & 1.967 & 8.126 \\
\hline Total & 9.273 & 28.437 & 18.184 & 21.520 & 52.157 & $4.92 \mathrm{E}-05$ & 13.853 & 53.059 \\
\hline
\end{tabular}


Table M.7 Absorbed Dose to Organs for a Reference Female Healthcare Provider from Reference Female Patient for Internal Contamination $(\mu \mathrm{Gy} / \mathrm{hr}) / A L I$

\begin{tabular}{|c|cccccccc|}
\hline Organ & ${ }^{\mathbf{6 0}} \mathbf{C o}(\mathbf{s})$ & ${ }^{\mathbf{6 0}} \mathbf{C o}(\mathbf{m})$ & ${ }^{\mathbf{1 9 2}} \mathbf{I r}(\mathbf{s})$ & ${ }^{\mathbf{1 9 2}} \mathbf{I r}(\mathbf{m})$ & ${ }^{\mathbf{1 9 2}} \mathbf{I r}(\mathbf{f})$ & ${ }^{\mathbf{2 4 1}} \mathbf{A m}$ & ${ }^{\mathbf{1 3 7}} \mathbf{C s}$ & ${ }^{\mathbf{1 3 1}} \mathbf{I}$ \\
\hline \hline Gonads & 0.403 & 1.211 & 0.702 & 0.880 & 2.208 & $1.63 \mathrm{E}-06$ & 0.711 & 0.217 \\
Stomach & 1.178 & 3.574 & 2.324 & 2.938 & 7.439 & $7.19 \mathrm{E}-06$ & 1.789 & 0.683 \\
Colon Wall & 1.397 & 4.337 & 2.622 & 3.294 & 7.764 & $6.68 \mathrm{E}-06$ & 2.410 & 0.749 \\
Bladder & 2.717 & 8.442 & 5.098 & 6.412 & 14.932 & $1.34 \mathrm{E}-05$ & 4.811 & 1.419 \\
Lungs & 0.345 & 1.061 & 0.635 & 0.802 & 1.875 & $1.80 \mathrm{E}-06$ & 0.571 & 0.206 \\
Bone & 0.417 & 1.292 & 0.801 & 1.011 & 2.475 & $3.63 \mathrm{E}-06$ & 0.687 & 0.242 \\
Liver & 0.464 & 1.457 & 0.937 & 1.173 & 2.437 & $2.86 \mathrm{E}-06$ & 0.913 & 0.282 \\
Thyroid & 0.422 & 1.285 & 0.872 & 1.104 & 2.625 & $3.23 \mathrm{E}-06$ & 0.692 & 0.287 \\
Esophagus & 0.282 & 0.881 & 0.452 & 0.566 & 1.387 & $9.07 \mathrm{E}-07$ & 0.397 & 0.149 \\
Skin & 0.374 & 1.158 & 0.649 & 0.818 & 1.979 & $1.96 \mathrm{E}-06$ & 0.617 & 0.204 \\
Other & 0.366 & 1.088 & 0.639 & 0.822 & 1.911 & $1.52 \mathrm{E}-06$ & 0.587 & 0.205 \\
Breast & 1.354 & 4.129 & 2.764 & 3.479 & 8.067 & $1.08 \mathrm{E}-05$ & 2.294 & 1.484 \\
\hline Total & 9.719 & 29.914 & 18.494 & 23.301 & 55.098 & $5.56 \mathrm{E}-05$ & 16.479 & 6.127 \\
\hline
\end{tabular}

Table M.8 Absorbed Dose to Organs for a Reference Female Healthcare Provider from Adipose Male Patient for Internal Contamination $(\mu \mathrm{Gy} / \mathrm{hr}) / \mathrm{ALI}$

\begin{tabular}{|c|cccccccc|}
\hline Organ & ${ }^{\mathbf{6 0}} \mathbf{C o}(\mathbf{s})$ & ${ }^{\mathbf{6 0}} \mathbf{C o}(\mathbf{m})$ & ${ }^{\mathbf{1 9 2}} \mathbf{I r}(\mathbf{s})$ & ${ }^{\mathbf{1 9 2}} \mathbf{I r}(\mathbf{m})$ & ${ }^{\mathbf{1 9 2}} \mathbf{I r}(\mathbf{f})$ & ${ }^{\mathbf{2 4 1}} \mathbf{A m}$ & ${ }^{\mathbf{1 3 7}} \mathbf{C s}$ & ${ }^{\mathbf{1 3 1}} \mathbf{I}$ \\
\hline \hline Gonads & 0.349 & 1.099 & 0.597 & 0.766 & 2.082 & $1.05 \mathrm{E}-06$ & 0.569 & 0.201 \\
Stomach & 1.037 & 3.129 & 1.891 & 2.412 & 7.216 & $4.79 \mathrm{E}-06$ & 1.755 & 0.589 \\
Colon Wall & 1.231 & 3.862 & 2.210 & 2.801 & 7.744 & $4.53 \mathrm{E}-06$ & 2.043 & 0.680 \\
Bladder & 2.473 & 7.741 & 4.596 & 5.788 & 15.735 & $1.05 \mathrm{E}-05$ & 4.065 & 1.350 \\
Lungs & 0.297 & 0.923 & 0.514 & 0.652 & 1.771 & $1.20 \mathrm{E}-06$ & 0.491 & 0.174 \\
Bone & 0.370 & 1.156 & 0.691 & 0.875 & 2.388 & $2.50 \mathrm{E}-06$ & 0.606 & 0.219 \\
Liver & 0.418 & 1.315 & 0.792 & 0.998 & 2.416 & $2.06 \mathrm{E}-06$ & 0.682 & 0.245 \\
Thyroid & 0.347 & 1.081 & 0.661 & 0.828 & 2.387 & $1.83 \mathrm{E}-06$ & 0.657 & 0.248 \\
Esophagus & 0.231 & 0.716 & 0.355 & 0.457 & 1.292 & $5.78 \mathrm{E}-07$ & 0.352 & 0.119 \\
Skin & 0.326 & 1.016 & 0.542 & 0.687 & 1.881 & $1.38 \mathrm{E}-06$ & 0.538 & 0.181 \\
Other & 0.328 & 0.994 & 2.230 & 0.686 & 1.904 & $1.25 \mathrm{E}-06$ & 0.495 & 0.179 \\
Breast & 1.156 & 3.586 & 24.542 & 2.824 & 7.598 & $7.12 \mathrm{E}-06$ & 1.981 & 0.716 \\
\hline Total & 8.563 & 26.619 & 39.620 & 19.774 & 54.413 & $3.87 \mathrm{E}-05$ & 14.235 & 4.904 \\
\hline
\end{tabular}


Table M.9 Absorbed Dose to Organs for a Reference Female Healthcare Provider from Adipose Female Patient for Internal Contamination $(\mu \mathrm{Gy} / \mathrm{hr}) / \mathrm{ALI}$

\begin{tabular}{|c|cccccccc|}
\hline Organ & ${ }^{\mathbf{6 0}} \mathbf{C o}(\mathbf{s})$ & ${ }^{\mathbf{6 0}} \mathbf{C o}(\mathbf{m})$ & ${ }^{\mathbf{1 9 2}} \mathbf{I r}(\mathbf{s})$ & ${ }^{\mathbf{1 9 2}^{\mathbf{I r}}(\mathbf{m})}$ & ${ }^{\mathbf{1 9 2}} \mathbf{I r}(\mathbf{f})$ & ${ }^{\mathbf{2 4 1}} \mathbf{A m}$ & ${ }^{{ }^{137}} \mathbf{C s}$ & ${ }^{\mathbf{1 3 1}_{\mathbf{I}}}$ \\
\hline \hline Gonads & 0.38 & 1.18 & 0.68 & 0.84 & 2.90 & $1.17 \mathrm{E}-06$ & 0.64 & 0.24 \\
Stomach & 1.14 & 3.43 & 2.19 & 2.79 & 8.53 & $6.14 \mathrm{E}-06$ & 1.89 & 0.75 \\
Colon Wall & 1.33 & 4.11 & 2.46 & 3.09 & 10.43 & $5.90 \mathrm{E}-06$ & 2.15 & 0.84 \\
Bladder & 2.66 & 8.29 & 4.92 & 6.21 & 20.67 & $1.20 \mathrm{E}-05$ & 4.14 & 1.58 \\
Lungs & 0.32 & 1.00 & 0.57 & 0.73 & 2.29 & $1.47 \mathrm{E}-06$ & 0.51 & 0.21 \\
Bone & 0.39 & 1.22 & 0.74 & 0.94 & 2.99 & $2.90 \mathrm{E}-06$ & 0.62 & 0.26 \\
Liver & 0.45 & 1.40 & 0.88 & 1.11 & 3.72 & $2.47 \mathrm{E}-06$ & 0.71 & 0.30 \\
Thyroid & 0.37 & 1.17 & 0.72 & 0.90 & 2.84 & $2.11 \mathrm{E}-06$ & 0.65 & 0.30 \\
Esophagus & 0.25 & 0.80 & 0.39 & 0.49 & 1.60 & $7.18 \mathrm{E}-07$ & 0.38 & 0.15 \\
Skin & 0.35 & 1.09 & 0.60 & 0.75 & 2.44 & $1.64 \mathrm{E}-06$ & 0.55 & 0.22 \\
Other & 0.35 & 1.09 & 0.58 & 0.74 & 2.48 & $1.24 \mathrm{E}-06$ & 0.54 & 0.23 \\
Breast & 1.24 & 3.81 & 2.47 & 3.13 & 9.94 & $8.48 \mathrm{E}-06$ & 2.06 & 0.87 \\
\hline Total & 9.22 & 28.60 & 17.21 & 21.74 & 70.83 & $4.62 \mathrm{E}-05$ & 14.84 & 5.94 \\
\hline
\end{tabular}

Table M.10 Absorbed Dose to Organs for a Reference Female Healthcare Provider from Postmenopausal Adipose Female Patient for Internal Contamination ( $\mu \mathrm{Gy} / \mathrm{hr}$ ) /ALI

\begin{tabular}{|c|cccccccc|}
\hline Organ & ${ }^{\mathbf{6 0}} \mathbf{C o}(\mathbf{s})$ & ${ }^{\mathbf{6 0}} \mathbf{C o}(\mathbf{m})$ & ${ }^{\mathbf{1 9 2}} \mathbf{I r}(\mathbf{s})$ & ${ }^{\mathbf{1 9 2}} \mathbf{I r}(\mathbf{m})$ & ${ }^{\mathbf{1 9 2}} \mathbf{I r}(\mathbf{f})$ & ${ }^{241} \mathbf{A m}$ & ${ }^{\mathbf{1 3 7}} \mathbf{C s}$ & ${ }^{\mathbf{1 3 1}} \mathbf{I}$ \\
\hline \hline Gonads & 0.365 & 1.141 & 0.659 & 0.836 & 2.037 & $1.27 \mathrm{E}-06$ & 0.921 & 0.194 \\
Stomach & 1.085 & 3.302 & 2.082 & 2.654 & 7.336 & $5.28 \mathrm{E}-06$ & 2.706 & 0.632 \\
Colon Wall & 1.303 & 4.051 & 2.382 & 3.003 & 7.818 & $5.27 \mathrm{E}-06$ & 3.200 & 0.712 \\
Bladder & 2.593 & 8.075 & 4.818 & 6.072 & 15.541 & $1.19 \mathrm{E}-05$ & 6.200 & 1.383 \\
Lungs & 0.310 & 0.959 & 0.538 & 0.684 & 1.788 & $1.30 \mathrm{E}-06$ & 0.771 & 0.180 \\
Bone & 0.381 & 1.190 & 0.715 & 0.905 & 2.378 & $2.63 \mathrm{E}-06$ & 0.948 & 0.223 \\
Liver & 0.429 & 1.347 & 0.834 & 1.047 & 2.381 & $2.21 \mathrm{E}-06$ & 1.025 & 0.253 \\
Thyroid & 0.344 & 1.072 & 0.668 & 0.864 & 2.415 & $2.00 \mathrm{E}-06$ & 0.927 & 0.240 \\
Esophagus & 0.249 & 0.802 & 0.369 & 0.465 & 1.337 & $6.41 \mathrm{E}-07$ & 0.559 & 0.122 \\
Skin & 0.338 & 1.050 & 0.565 & 0.715 & 1.898 & $1.47 \mathrm{E}-06$ & 0.840 & 0.185 \\
Other & 0.327 & 1.006 & 0.557 & 0.707 & 1.898 & $1.09 \mathrm{E}-06$ & 0.820 & 0.183 \\
Breast & 1.210 & 3.731 & 2.361 & 2.993 & 7.658 & $7.74 \mathrm{E}-06$ & 2.959 & 0.738 \\
\hline Total & 8.933 & 27.727 & 16.547 & 20.946 & 54.485 & $4.28 \mathrm{E}-05$ & 21.875 & 5.046 \\
\hline
\end{tabular}


Table M.11 Absorbed Dose to Organs for an Adipose Male Healthcare Provider from Reference Male Patient for Internal Contamination $(\mu \mathrm{Gy} / \mathrm{hr}) / \mathrm{ALI}$

\begin{tabular}{|c|c|c|c|c|c|c|c|c|}
\hline Organ & ${ }^{60} \mathrm{Co}(\mathrm{s})$ & ${ }^{60} \mathrm{Co}(\mathrm{m})$ & ${ }^{192} \operatorname{Ir}(\mathrm{s})$ & ${ }^{192} \operatorname{Ir}(\mathrm{m})$ & ${ }^{192} \operatorname{Ir}(f)$ & ${ }^{241} \mathrm{Am}$ & ${ }^{137} \mathrm{Cs}$ & ${ }^{131} \mathbf{I}$ \\
\hline & 0 & 1.5 & 0.830 & 0.990 & 2.347 & $1.83 \mathrm{~F}$ & 0.654 & 0.247 \\
\hline Stomach & 0.930 & 2.765 & 1.661 & 1.895 & 5.145 & $3.28 \mathrm{E}-06$ & 1.331 & 0.503 \\
\hline Colon Wall & 0.959 & 2.981 & 1.512 & 1.760 & 4.550 & $1.91 \mathrm{E}-06$ & 1.365 & 0.484 \\
\hline Bladder & 1.588 & 4.940 & 2.612 & 3.042 & 7.706 & $3.51 \mathrm{E}-06$ & 2.234 & 0.774 \\
\hline Lungs & 0.291 & 0.888 & 0.525 & 0.640 & 1.487 & $1.28 \mathrm{E}-06$ & 0.412 & 0.162 \\
\hline Bone & 0.354 & 1.098 & 0.690 & 0.829 & 2.019 & $2.50 \mathrm{E}-06$ & 0.524 & 0.207 \\
\hline Liver & 0.366 & 1.156 & 0.673 & 0.824 & 1.594 & $1.64 \mathrm{E}-06$ & 0.517 & 0.202 \\
\hline Thyroid & 0.404 & 1.213 & 0.733 & 0.926 & 2.133 & $2.11 \mathrm{E}-06$ & 0.592 & 0.226 \\
\hline Esophagus & 0.186 & 0.585 & 0.292 & 0.350 & 0.824 & $5.25 \mathrm{E}-07$ & 0.244 & 0.091 \\
\hline Skin & 0.273 & 0.842 & 0.498 & 0.595 & 1.449 & $1.41 \mathrm{E}-06$ & 0.408 & 0.150 \\
\hline Other & 0.238 & 0.736 & 0.444 & 0.518 & 1.090 & $6.93 \mathrm{E}-07$ & 0.334 & 0.126 \\
\hline Breast & 0.812 & 2.434 & 1.574 & 2.098 & 4.521 & $6.16 \mathrm{E}-06$ & 1.153 & 0.489 \\
\hline Total & 6.886 & 21.139 & 12.043 & 14.465 & 34.867 & $2.68 \mathrm{E}-05$ & 9.770 & 3.660 \\
\hline
\end{tabular}

Table M.12 Absorbed Dose to Organs for an Adipose Male Healthcare Provider from Reference Female Patient for Internal Contamination $(\mu \mathrm{Gy} / \mathrm{hr}) / A L I$

\begin{tabular}{|c|cccccccc|}
\hline Organ & ${ }^{\mathbf{6 0}} \mathbf{C o}(\mathbf{s})$ & ${ }^{\mathbf{6 0}} \mathbf{C o}(\mathbf{m})$ & ${ }^{192} \mathbf{I r}(\mathbf{s})$ & ${ }^{\mathbf{1 9 2}} \mathbf{I r}(\mathbf{m})$ & ${ }^{\mathbf{1 9 2}} \mathbf{I r}(\mathbf{f})$ & ${ }^{\mathbf{2 4 1}_{\mathbf{A m}}}$ & ${ }^{\mathbf{1 3 7}} \mathbf{C s}$ & ${ }^{\mathbf{1 3 1}} \mathbf{I}$ \\
\hline \hline Gonads & 0.454 & 1.397 & 0.714 & 0.934 & 1.965 & $1.50 \mathrm{E}-06$ & 0.762 & 0.204 \\
Stomach & 0.977 & 2.930 & 1.603 & 1.727 & 5.629 & $3.80 \mathrm{E}-06$ & 1.198 & 0.505 \\
Colon Wall & 1.020 & 3.186 & 1.493 & 1.615 & 4.650 & $2.10 \mathrm{E}-06$ & 1.578 & 0.477 \\
Bladder & 1.694 & 5.320 & 2.548 & 2.736 & 7.753 & $3.62 \mathrm{E}-06$ & 2.708 & 0.746 \\
Lungs & 0.302 & 0.923 & 0.526 & 0.533 & 1.576 & $1.37 \mathrm{E}-06$ & 0.474 & 0.170 \\
Bone & 0.357 & 1.108 & 0.659 & 0.723 & 2.040 & $2.51 \mathrm{E}-06$ & 0.585 & 0.205 \\
Liver & 0.375 & 1.185 & 0.690 & 0.741 & 1.687 & $1.76 \mathrm{E}-06$ & 0.742 & 0.218 \\
Thyroid & 0.405 & 1.254 & 0.746 & 0.721 & 2.390 & $2.50 \mathrm{E}-06$ & 0.651 & 0.252 \\
Esophagus & 0.194 & 0.580 & 0.289 & 0.283 & 0.908 & $5.16 \mathrm{E}-07$ & 0.279 & 0.099 \\
Skin & 0.282 & 0.871 & 0.492 & 0.521 & 1.485 & $1.49 \mathrm{E}-06$ & 0.469 & 0.150 \\
Other & 0.239 & 0.726 & 0.360 & 0.469 & 1.209 & $7.75 \mathrm{E}-07$ & 0.347 & 0.127 \\
Breast & 0.728 & 2.127 & 1.650 & 2.054 & 4.766 & $7.19 \mathrm{E}-06$ & 1.244 & 0.490 \\
\hline Total & 7.028 & 21.608 & 11.770 & 13.057 & 36.056 & $2.91 \mathrm{E}-05$ & 11.037 & 3.643 \\
\hline
\end{tabular}


Table M.13 Absorbed Dose to Organs for an Adipose Male Healthcare Provider from Adipose Male Patient for Internal Contamination $(\mu \mathrm{Gy} / \mathrm{hr}) / \mathrm{ALI}$

\begin{tabular}{|c|c|c|c|c|c|c|c|c|}
\hline Organ & ${ }^{60} \mathrm{Co}(\mathrm{s})$ & ${ }^{60} \mathrm{Co}(\mathrm{m})$ & ${ }^{192} \operatorname{Ir}(\mathrm{s})$ & ${ }^{192} \operatorname{Ir}(\mathrm{m})$ & ${ }^{192} \operatorname{Ir}(f)$ & ${ }^{241} \mathrm{Am}$ & ${ }^{137} \mathrm{Cs}$ & ${ }^{131} \mathbf{I}$ \\
\hline & 0.4 & 1.4 & 0.740 & 0.9 & 2.1 & $1.41 \mathrm{~F}$ & 0.622 & 0.197 \\
\hline Stomach & 0.854 & 2.561 & 1.348 & 1.727 & 5.363 & $2.45 \mathrm{E}-06$ & 1.385 & 0.451 \\
\hline Colon Wall & 0.876 & 2.773 & 1.275 & 1.615 & 4.569 & $1.55 \mathrm{E}-06$ & 1.380 & 0.432 \\
\hline Bladder & 1.470 & 4.612 & 2.174 & 2.736 & 7.479 & $2.68 \mathrm{E}-06$ & 2.188 & 0.664 \\
\hline Lungs & 0.254 & 0.789 & 0.420 & 0.533 & 1.449 & $8.55 \mathrm{E}-07$ & 0.411 & 0.144 \\
\hline Bone & 0.318 & 0.996 & 0.571 & 0.723 & 1.943 & $1.74 \mathrm{E}-06$ & 0.508 & 0.185 \\
\hline Liver & 0.338 & 1.073 & 0.588 & 0.741 & 1.702 & $1.25 \mathrm{E}-06$ & 0.526 & 0.190 \\
\hline Thyroid & 0.334 & 1.040 & 0.556 & 0.721 & 2.079 & $1.33 \mathrm{E}-06$ & 0.589 & 0.210 \\
\hline Esophagus & 0.161 & 0.494 & 0.219 & 0.2 & 0.857 & $2.45 \mathrm{E}-07$ & 0.239 & 0.081 \\
\hline Skin & 0.248 & 0.773 & 0.411 & 0.521 & 1.422 & $1.06 \mathrm{E}-06$ & 0.401 & 0.133 \\
\hline Other & 0.202 & 0.629 & 0.319 & 0.404 & 1.078 & $4.57 \mathrm{E}-07$ & 0.323 & 0.107 \\
\hline Breast & 0.704 & 2.059 & 1.308 & 1.595 & 4.554 & $4.43 \mathrm{E}-06$ & 1.229 & 0.394 \\
\hline Total & 6.216 & 19.200 & 9.929 & 12.532 & 34.641 & $1.94 \mathrm{E}-05$ & 9.803 & 3.188 \\
\hline
\end{tabular}

Table M.14 Absorbed Dose to Organs for an Adipose Male Healthcare Provider from Adipose Female Patient for Internal Contamination ( $\mu \mathrm{Gy} / \mathrm{hr}) / \mathrm{ALI}$

\begin{tabular}{|c|cccccccc|}
\hline Organ & ${ }^{\mathbf{6 0}} \mathbf{C o}(\mathbf{s})$ & ${ }^{\mathbf{6 0}} \mathbf{C o}(\mathbf{m})$ & ${ }^{\mathbf{1 9 2}} \mathbf{I r}(\mathbf{s})$ & ${ }^{\mathbf{1 9 2}} \mathbf{I r}(\mathbf{m})$ & ${ }^{\mathbf{1 9 2}} \mathbf{I r}(\mathbf{f})$ & ${ }^{241} \mathbf{A m}$ & ${ }^{\mathbf{1 3 7}} \mathbf{C s}$ & ${ }^{\mathbf{1 3 1}} \mathbf{I}$ \\
\hline \hline Gonads & 0.440 & 1.352 & 0.698 & 0.870 & 1.823 & $1.45 \mathrm{E}-06$ & 0.588 & 0.221 \\
Stomach & 0.939 & 2.817 & 1.509 & 1.938 & 5.884 & $3.24 \mathrm{E}-06$ & 1.494 & 0.563 \\
Colon Wall & 0.964 & 3.033 & 1.408 & 1.770 & 4.773 & $1.91 \mathrm{E}-06$ & 1.448 & 0.515 \\
Bladder & 1.616 & 5.091 & 2.385 & 3.027 & 7.743 & $3.12 \mathrm{E}-06$ & 2.308 & 0.803 \\
Lungs & 0.272 & 0.841 & 0.461 & 0.588 & 1.570 & $1.02 \mathrm{E}-06$ & 0.425 & 0.176 \\
Bone & 0.334 & 1.044 & 0.606 & 0.767 & 2.021 & $1.98 \mathrm{E}-06$ & 0.521 & 0.217 \\
Liver & 0.360 & 1.142 & 0.643 & 0.809 & 1.745 & $1.50 \mathrm{E}-06$ & 0.541 & 0.231 \\
Thyroid & 0.358 & 1.146 & 0.620 & 0.792 & 2.238 & $1.58 \mathrm{E}-06$ & 0.569 & 0.255 \\
Esophagus & 0.179 & 0.549 & 0.261 & 0.325 & 0.916 & $3.92 \mathrm{E}-07$ & 0.254 & 0.103 \\
Skin & 0.265 & 0.826 & 0.453 & 0.572 & 1.487 & $1.25 \mathrm{E}-06$ & 0.418 & 0.160 \\
Other & 0.224 & 0.689 & 0.341 & 0.446 & 1.271 & $5.54 \mathrm{E}-07$ & 0.351 & 0.140 \\
Breast & 0.613 & 2.055 & 1.492 & 1.988 & 4.659 & $5.78 \mathrm{E}-06$ & 1.285 & 0.498 \\
\hline Total & 6.565 & 20.585 & 10.877 & 13.893 & 36.129 & $2.38 \mathrm{E}-05$ & 10.201 & 3.884 \\
\hline
\end{tabular}


Table M.15 Absorbed Dose to Organs for an Adipose Male Healthcare Provider from Postmenopausal Adipose Female Patient for Internal Contamination ( $\mu \mathrm{Gy} / \mathrm{hr}) / \mathrm{ALI}$

\begin{tabular}{|c|cccccccc|}
\hline Organ & ${ }^{\mathbf{6}} \mathbf{C o}(\mathbf{s})$ & ${ }^{\mathbf{6 0}} \mathbf{C o}(\mathbf{m})$ & ${ }^{\mathbf{1 9 2}} \mathbf{I r}(\mathbf{s})$ & ${ }^{\mathbf{1 9 2}} \mathbf{I r}(\mathbf{m})$ & ${ }^{\mathbf{1 9 2}} \mathbf{I r}(\mathbf{f})$ & ${ }^{241} \mathbf{A m}$ & ${ }^{\mathbf{1 3 7}} \mathbf{C s}$ & ${ }^{\mathbf{1 3 1}} \mathbf{I}$ \\
\hline \hline Gonads & 0.468 & 1.424 & 0.739 & 0.919 & 2.863 & $1.41 \mathrm{E}-06$ & 0.982 & 0.204 \\
Stomach & 0.890 & 2.688 & 1.426 & 1.828 & 5.344 & $2.83 \mathrm{E}-06$ & 2.257 & 0.474 \\
Colon Wall & 0.926 & 2.896 & 1.329 & 1.681 & 5.833 & $1.59 \mathrm{E}-06$ & 2.329 & 0.442 \\
Bladder & 1.539 & 4.810 & 2.264 & 2.846 & 9.928 & $2.97 \mathrm{E}-06$ & 3.669 & 0.684 \\
Lungs & 0.265 & 0.823 & 0.438 & 0.555 & 1.756 & $9.40 \mathrm{E}-07$ & 0.648 & 0.148 \\
Bone & 0.326 & 1.016 & 0.586 & 0.741 & 2.384 & $1.79 \mathrm{E}-06$ & 0.807 & 0.187 \\
Liver & 0.345 & 1.091 & 0.609 & 0.763 & 2.637 & $1.29 \mathrm{E}-06$ & 0.812 & 0.192 \\
Thyroid & 0.332 & 1.026 & 0.568 & 0.719 & 2.377 & $1.50 \mathrm{E}-06$ & 0.858 & 0.208 \\
Esophagus & 0.163 & 0.497 & 0.244 & 0.306 & 0.965 & $2.85 \mathrm{E}-07$ & 0.391 & 0.086 \\
Skin & 0.256 & 0.797 & 0.431 & 0.545 & 1.837 & $1.14 \mathrm{E}-06$ & 0.630 & 0.137 \\
Other & 0.202 & 0.635 & 0.315 & 0.400 & 1.310 & $4.88 \mathrm{E}-07$ & 0.528 & 0.113 \\
Breast & 0.603 & 1.915 & 1.400 & 1.777 & 5.641 & $4.81 \mathrm{E}-06$ & 1.710 & 0.424 \\
\hline Total & 6.316 & 19.616 & 10.349 & 13.080 & 42.878 & $2.11 \mathrm{E}-05$ & 15.622 & 3.299 \\
\hline
\end{tabular}

Table M.16 Absorbed Dose to Organs for an Adipose Female Healthcare Provider from Reference Male Patient for Internal Contamination ( $\mu \mathrm{Gy} / \mathrm{hr}) / \mathrm{ALI}$

\begin{tabular}{|c|cccccccc|}
\hline Organ & ${ }^{\mathbf{6 0}} \mathbf{C o}(\mathbf{s})$ & ${ }^{\mathbf{6 0}} \mathbf{C o}(\mathbf{m})$ & ${ }^{\mathbf{1 9 2}} \mathbf{I r}(\mathbf{s})$ & ${ }^{\mathbf{1 9 2}} \mathbf{I r}(\mathbf{m})$ & ${ }^{\mathbf{1 9 2}} \mathbf{I r}(\mathbf{f})$ & ${ }^{\mathbf{2 4 1}} \mathbf{A m}$ & ${ }^{\mathbf{1 3 7}} \mathbf{C s}$ & ${ }^{\mathbf{1 3 1}} \mathbf{I}$ \\
\hline \hline Gonads & 0.263 & 0.834 & 0.456 & 0.527 & 1.185 & $4.64 \mathrm{E}-07$ & 0.350 & 0.122 \\
Stomach & 0.973 & 2.905 & 1.850 & 2.119 & 5.606 & $4.11 \mathrm{E}-06$ & 1.464 & 0.547 \\
Colon Wall & 0.917 & 2.847 & 1.551 & 1.811 & 4.614 & $2.37 \mathrm{E}-06$ & 1.385 & 0.476 \\
Bladder & 1.824 & 5.577 & 3.062 & 3.609 & 9.186 & $4.85 \mathrm{E}-06$ & 2.630 & 0.929 \\
Lungs & 0.321 & 0.980 & 0.584 & 0.704 & 1.631 & $1.43 \mathrm{E}-06$ & 0.466 & 0.180 \\
Bone & 0.388 & 1.200 & 0.762 & 0.916 & 2.219 & $2.94 \mathrm{E}-06$ & 0.574 & 0.226 \\
Liver & 0.416 & 1.306 & 0.807 & 0.980 & 1.970 & $2.15 \mathrm{E}-06$ & 0.601 & 0.238 \\
Thyroid & 0.403 & 1.230 & 0.810 & 0.989 & 2.416 & $2.69 \mathrm{E}-06$ & 0.584 & 0.244 \\
Esophagus & 0.248 & 0.779 & 0.384 & 0.468 & 1.245 & $5.98 \mathrm{E}-07$ & 0.335 & 0.121 \\
Skin & 0.445 & 1.373 & 0.824 & 0.984 & 2.383 & $2.40 \mathrm{E}-06$ & 0.668 & 0.226 \\
Other & 0.294 & 0.874 & 0.497 & 0.604 & 1.400 & $8.81 \mathrm{E}-07$ & 0.433 & 0.153 \\
Breast & 1.563 & 4.768 & 3.279 & 3.987 & 9.065 & $1.22 \mathrm{E}-05$ & 2.336 & 0.962 \\
\hline Total & 8.056 & 24.674 & 14.865 & 17.697 & 42.920 & $3.71 \mathrm{E}-05$ & 11.826 & 4.425 \\
\hline
\end{tabular}


Table M.17 Absorbed Dose to Organs for an Adipose Female Healthcare Provider from Reference Female Patient for Internal Contamination ( $\mu \mathrm{Gy} / \mathrm{hr}) / \mathrm{ALI}$

\begin{tabular}{|l|rrrrrrrr|}
\hline Organ & ${ }^{\mathbf{6 0}} \mathbf{C o}(\mathbf{s})$ & ${ }^{\mathbf{6 0}} \mathbf{C o}(\mathbf{m})$ & ${ }^{\mathbf{1 9 2}} \mathbf{I r}(\mathbf{s})$ & ${ }^{\mathbf{1 9 2}} \mathbf{I r}(\mathbf{m})$ & ${ }^{\mathbf{1 9 2}} \mathbf{I r}(\mathbf{f})$ & ${ }^{\mathbf{2 4 1}} \mathbf{A m}$ & ${ }^{\mathbf{1 3 7}} \mathbf{C s}$ & ${ }^{\mathbf{1 3 1}} \mathbf{I}$ \\
\hline \hline Gonads & 0.268 & 0.860 & 0.393 & 0.508 & 1.267 & $7.20 \mathrm{E}-07$ & 0.393 & 0.136 \\
Stomach & 1.041 & 3.105 & 1.865 & 2.355 & 6.147 & $4.79 \mathrm{E}-06$ & 1.400 & 0.560 \\
Colon Wall & 0.978 & 3.064 & 1.518 & 1.919 & 4.736 & $2.66 \mathrm{E}-06$ & 1.567 & 0.473 \\
Bladder & 1.893 & 5.919 & 3.044 & 3.827 & 9.128 & $4.90 \mathrm{E}-06$ & 3.102 & 0.872 \\
Lungs & 0.333 & 1.022 & 0.588 & 0.744 & 1.751 & $1.53 \mathrm{E}-06$ & 0.534 & 0.187 \\
Bone & 0.390 & 1.211 & 0.732 & 0.923 & 2.255 & $3.00 \mathrm{E}-06$ & 0.641 & 0.224 \\
Liver & 0.435 & 1.370 & 0.833 & 1.040 & 2.087 & $2.31 \mathrm{E}-06$ & 0.857 & 0.255 \\
Thyroid & 0.401 & 1.215 & 0.777 & 0.990 & 2.462 & $2.47 \mathrm{E}-06$ & 0.650 & 0.255 \\
Esophagus & 0.255 & 0.809 & 0.421 & 0.527 & 1.284 & $7.41 \mathrm{E}-07$ & 0.390 & 0.136 \\
Skin & 0.462 & 1.424 & 0.823 & 1.037 & 2.469 & $2.58 \mathrm{E}-06$ & 0.769 & 0.227 \\
Other & 0.311 & 0.935 & 0.497 & 0.641 & 1.535 & $9.66 \mathrm{E}-07$ & 0.465 & 0.165 \\
Breast & 1.609 & 4.910 & 3.294 & 4.144 & 9.651 & $1.30 \mathrm{E}-05$ & 2.720 & 0.994 \\
\hline Total & 8.376 & 25.844 & 14.785 & 18.655 & 44.770 & $3.97 \mathrm{E}-05$ & 13.490 & 4.484 \\
\hline
\end{tabular}

Table M.18 Absorbed Dose to Organs for an Adipose Female Healthcare Provider from Adipose Male Patient for Internal Contamination $(\mu \mathrm{Gy} / \mathrm{hr}) / \mathrm{ALI}$

\begin{tabular}{|c|cccccccc|}
\hline Organ & ${ }^{\mathbf{6 0}} \mathbf{C o}(\mathbf{s})$ & ${ }^{\mathbf{6 0}} \mathbf{C o}(\mathbf{m})$ & ${ }^{\mathbf{1 9 2}} \mathbf{I r}(\mathbf{s})$ & ${ }^{\mathbf{1 9 2}} \mathbf{I r}(\mathbf{m})$ & ${ }^{\mathbf{1 9 2}} \mathbf{I r}(\mathbf{f})$ & ${ }^{\mathbf{2 4 1}_{\mathbf{A m}}}$ & ${ }^{{ }^{\mathbf{3 7}} \mathbf{C s}}$ & ${ }^{\mathbf{1 3 1}} \mathbf{I}$ \\
\hline \hline Gonads & 0.245 & 0.766 & 0.352 & 0.448 & 1.236 & $3.87 \mathrm{E}-07$ & 0.392 & 0.108 \\
Stomach & 0.910 & 2.743 & 1.520 & 1.950 & 5.938 & $3.28 \mathrm{E}-06$ & 1.509 & 0.492 \\
Colon Wall & 0.855 & 2.675 & 1.307 & 1.671 & 4.684 & $1.83 \mathrm{E}-06$ & 1.384 & 0.426 \\
Bladder & 1.690 & 5.269 & 2.586 & 3.262 & 8.949 & $3.58 \mathrm{E}-06$ & 2.589 & 0.803 \\
Lungs & 0.281 & 0.875 & 0.474 & 0.603 & 1.610 & $1.02 \mathrm{E}-06$ & 0.459 & 0.160 \\
Bone & 0.350 & 1.094 & 0.636 & 0.807 & 2.169 & $2.09 \mathrm{E}-06$ & 0.562 & 0.203 \\
Liver & 0.389 & 1.228 & 0.706 & 0.889 & 2.081 & $1.66 \mathrm{E}-06$ & 0.617 & 0.222 \\
Thyroid & 0.350 & 1.066 & 0.569 & 0.718 & 2.314 & $1.48 \mathrm{E}-06$ & 0.583 & 0.210 \\
Esophagus & 0.218 & 0.679 & 0.319 & 0.404 & 1.155 & $4.76 \mathrm{E}-07$ & 0.337 & 0.118 \\
Skin & 0.403 & 1.254 & 0.682 & 0.867 & 2.379 & $1.81 \mathrm{E}-06$ & 0.663 & 0.201 \\
Other & 0.273 & 0.829 & 0.415 & 0.525 & 1.429 & $6.51 \mathrm{E}-07$ & 0.414 & 0.141 \\
Breast & 1.368 & 4.239 & 2.644 & 3.353 & 9.050 & $8.49 \mathrm{E}-06$ & 2.339 & 0.850 \\
\hline Total & 7.333 & 22.715 & 12.212 & 15.494 & 42.994 & $2.68 \mathrm{E}-05$ & 11.850 & 3.935 \\
\hline
\end{tabular}


Table M.19 Absorbed Dose to Organs for an Adipose Female Healthcare Provider from Adipose Female Patient for Internal Contamination $(\mu \mathrm{Gy} / \mathrm{hr}) / \mathrm{ALI}$

\begin{tabular}{|c|cccccccc|}
\hline Organ & ${ }^{\mathbf{6 0}} \mathbf{C o}(\mathbf{s})$ & ${ }^{\mathbf{6 0}} \mathbf{C o}(\mathbf{m})$ & ${ }^{\mathbf{1 9 2}} \mathbf{I r}(\mathbf{s})$ & ${ }^{\mathbf{1 9 2} \mathbf{I r}(\mathbf{m})}$ & ${ }^{\mathbf{1 9 2} \mathbf{I r}(\mathbf{f})}$ & ${ }^{\mathbf{2 4 1}} \mathbf{A m}$ & ${ }^{{ }^{137}} \mathbf{C s}$ & ${ }^{\mathbf{1 3 1}_{\mathbf{I}}}$ \\
\hline \hline Gonads & 0.183 & 0.778 & 0.394 & 0.497 & 1.592 & $6.82 \mathrm{E}-07$ & 0.366 & 0.119 \\
Stomach & 0.715 & 2.980 & 1.761 & 2.240 & 6.650 & $4.21 \mathrm{E}-06$ & 1.622 & 0.555 \\
Colon Wall & 0.678 & 2.930 & 1.427 & 1.808 & 6.100 & $2.14 \mathrm{E}-06$ & 1.417 & 0.456 \\
Bladder & 1.318 & 5.740 & 2.826 & 3.549 & 11.993 & $4.24 \mathrm{E}-06$ & 2.600 & 0.833 \\
Lungs & 0.219 & 0.941 & 0.526 & 0.665 & 2.087 & $1.22 \mathrm{E}-06$ & 0.478 & 0.174 \\
Bone & 0.265 & 1.146 & 0.675 & 0.854 & 2.719 & $2.39 \mathrm{E}-06$ & 0.575 & 0.214 \\
Liver & 0.298 & 1.310 & 0.781 & 0.982 & 3.320 & $1.98 \mathrm{E}-06$ & 0.641 & 0.241 \\
Thyroid & 0.243 & 1.039 & 0.642 & 0.803 & 2.429 & $1.88 \mathrm{E}-06$ & 0.601 & 0.231 \\
Esophagus & 0.176 & 0.737 & 0.351 & 0.435 & 1.452 & $5.38 \mathrm{E}-07$ & 0.372 & 0.127 \\
Skin & 0.312 & 1.353 & 0.757 & 0.958 & 3.128 & $2.16 \mathrm{E}-06$ & 0.688 & 0.218 \\
Other & 0.209 & 0.923 & 0.448 & 0.574 & 1.819 & $8.02 \mathrm{E}-07$ & 0.437 & 0.158 \\
Breast & 1.054 & 4.527 & 2.936 & 3.723 & 11.778 & $1.02 \mathrm{E}-05$ & 2.434 & 0.928 \\
\hline Total & 5.670 & 24.405 & 13.525 & 17.087 & 55.066 & $3.24 \mathrm{E}-05$ & 12.232 & 4.254 \\
\hline
\end{tabular}

Table M.20 Absorbed Dose to Organs for an Adipose Female Healthcare Provider from Postmenopausal Adipose Female Patient for Internal Contamination ( $\mu \mathrm{Gy} / \mathrm{hr}) / \mathrm{ALI}$

\begin{tabular}{|c|cccccccc|}
\hline Organ & ${ }^{\mathbf{6 0}} \mathbf{C o}(\mathbf{s})$ & ${ }^{\mathbf{6 0}} \mathbf{C o}(\mathbf{m})$ & ${ }^{\mathbf{1 9 2}} \mathbf{I r}(\mathbf{s})$ & ${ }^{\mathbf{1 9 2}} \mathbf{I r}(\mathbf{m})$ & ${ }^{\mathbf{1 9 2}} \mathbf{I r}(\mathbf{f})$ & ${ }^{{ }^{241}} \mathbf{A m}$ & ${ }^{\mathbf{1 3 7}} \mathbf{C s}$ & ${ }^{\mathbf{1 3 1}} \mathbf{I}$ \\
\hline \hline Gonads & 0.183 & 0.809 & 0.375 & 0.462 & 1.174 & $5.37 \mathrm{E}-07$ & 0.625 & 0.115 \\
Stomach & 0.690 & 2.872 & 1.660 & 2.117 & 6.131 & $3.72 \mathrm{E}-06$ & 2.393 & 0.520 \\
Colon Wall & 0.651 & 2.830 & 1.356 & 1.730 & 4.689 & $2.00 \mathrm{E}-06$ & 2.308 & 0.444 \\
Bladder & 1.245 & 5.431 & 2.728 & 3.447 & 8.741 & $4.03 \mathrm{E}-06$ & 4.240 & 0.811 \\
Lungs & 0.212 & 0.913 & 0.497 & 0.629 & 1.644 & $1.09 \mathrm{E}-06$ & 0.715 & 0.163 \\
Bone & 0.257 & 1.112 & 0.654 & 0.826 & 2.170 & $2.17 \mathrm{E}-06$ & 0.889 & 0.206 \\
Liver & 0.288 & 1.262 & 0.737 & 0.924 & 2.045 & $1.76 \mathrm{E}-06$ & 0.948 & 0.227 \\
Thyroid & 0.241 & 1.044 & 0.640 & 0.802 & 2.253 & $1.70 \mathrm{E}-06$ & 0.920 & 0.218 \\
Esophagus & 0.159 & 0.687 & 0.343 & 0.434 & 1.130 & $4.13 \mathrm{E}-07$ & 0.544 & 0.114 \\
Skin & 0.301 & 1.298 & 0.720 & 0.911 & 2.389 & $1.93 \mathrm{E}-06$ & 1.034 & 0.208 \\
Other & 0.209 & 0.892 & 0.414 & 0.525 & 1.491 & $7.10 \mathrm{E}-07$ & 0.684 & 0.146 \\
Breast & 1.030 & 4.405 & 2.798 & 3.543 & 9.109 & $9.19 \mathrm{E}-06$ & 3.491 & 0.873 \\
\hline Total & 5.467 & 23.556 & 12.920 & 16.350 & 42.966 & $2.93 \mathrm{E}-05$ & 18.789 & 4.046 \\
\hline
\end{tabular}


Table M.21 Absorbed Dose to Organs for a Postmenopausal Adipose Female Healthcare

Provider from Reference Male Patient for Internal Contamination $(\mu \mathrm{Gy} / \mathrm{hr}) / \mathrm{ALI}$

\begin{tabular}{|c|c|c|c|c|c|c|c|c|}
\hline Organ & $\begin{array}{c}{ }^{60} \mathrm{Co} \\
(\mathrm{s})\end{array}$ & ${ }^{60} \mathrm{Co}(\mathrm{m})$ & ${ }^{192} \operatorname{Ir}(\mathrm{s})$ & ${ }^{192} \operatorname{Ir}(\mathrm{m})$ & ${ }^{192} \operatorname{Ir}(f)$ & ${ }^{241} \mathrm{Am}$ & ${ }^{137} \mathrm{Cs}$ & ${ }^{131} \mathbf{I}$ \\
\hline Gonads & 0.363 & 1.515 & 0.780 & 0.874 & 2.238 & $9.22 \mathrm{E}-07$ & 0.724 & 0.247 \\
\hline Stomach & 0.637 & 2.646 & 1.645 & 1.861 & 5.105 & $3.54 \mathrm{E}-06$ & 1.301 & 0.488 \\
\hline Colon Wall & 0.604 & 2.637 & 1.377 & 1.607 & 4.032 & $1.83 \mathrm{E}-06$ & 1.241 & 0.431 \\
\hline Bladder & 1.180 & 5.083 & 2.676 & 3.128 & 7.965 & $3.74 \mathrm{E}-06$ & 2.317 & 0.798 \\
\hline Lungs & 0.225 & 0.954 & 0.560 & 0.674 & 1.572 & $1.29 \mathrm{E}-06$ & 0.445 & 0.170 \\
\hline Bone & 0.271 & 1.164 & 0.744 & 0.892 & 2.165 & 2.69E-06 & 0.559 & 0.221 \\
\hline Liver & 0.286 & 1.251 & 0.741 & 0.904 & 1.786 & $1.86 \mathrm{E}-06$ & 0.567 & 0.222 \\
\hline Thyroid & 0.404 & 1.729 & 1.068 & 1.320 & 3.299 & $3.44 \mathrm{E}-06$ & 0.844 & 0.338 \\
\hline Esophagus & 0.182 & 0.781 & 0.375 & 0.464 & 1.165 & $5.22 \mathrm{E}-07$ & 0.327 & 0.118 \\
\hline Skin & 0.293 & 1.251 & 0.751 & 0.896 & 2.185 & 2.18E-06 & 0.608 & 0.227 \\
\hline Other & 0.201 & 0.837 & 0.473 & 0.558 & 1.330 & 7.63E-07 & 0.411 & 0.144 \\
\hline Breast & 1.049 & 4.429 & 3.071 & 3.735 & 8.467 & $1.15 \mathrm{E}-05$ & 2.171 & 0.898 \\
\hline Total & 5.696 & 24.276 & 14.262 & 16.911 & 41.310 & $3.43 \mathrm{E}-05$ & 11.516 & 4.303 \\
\hline
\end{tabular}

Table M.22 Absorbed Dose to Organs for a Postmenopausal Adipose Female Healthcare Provider from Reference Female Patient for Internal Contamination ( $\mu \mathrm{Gy} / \mathrm{hr}) / \mathrm{ALI}$

\begin{tabular}{|c|cccccccc|}
\hline Organ & ${ }^{\mathbf{6 0}} \mathbf{C o}(\mathbf{s})$ & ${ }^{\mathbf{6 0}} \mathbf{C o}(\mathbf{m})$ & ${ }^{\mathbf{1 9 2}} \mathbf{I r}(\mathbf{s})$ & ${ }^{\mathbf{1 9 2}} \mathbf{I r}(\mathbf{m})$ & ${ }^{\mathbf{1 9 2}} \mathbf{I r}(\mathbf{f})$ & ${ }^{\mathbf{2 4 1}} \mathbf{A m}$ & ${ }^{\mathbf{1 3 7}} \mathbf{C s}$ & ${ }^{\mathbf{1 3 1}} \mathbf{I}$ \\
\hline \hline Gonads & 0.581 & 1.766 & 0.750 & 0.953 & 2.362 & $8.20 \mathrm{E}-07$ & 0.846 & 0.205 \\
Stomach & 0.955 & 2.872 & 1.632 & 2.064 & 5.558 & $4.11 \mathrm{E}-06$ & 1.219 & 0.504 \\
Colon Wall & 0.892 & 2.792 & 1.352 & 1.702 & 4.215 & $2.10 \mathrm{E}-06$ & 1.403 & 0.418 \\
Bladder & 1.708 & 5.347 & 2.554 & 3.218 & 7.889 & $3.72 \mathrm{E}-06$ & 2.714 & 0.763 \\
Lungs & 0.321 & 0.988 & 0.561 & 0.709 & 1.665 & $1.40 \mathrm{E}-06$ & 0.515 & 0.181 \\
Bone & 0.380 & 1.177 & 0.712 & 0.900 & 2.189 & $2.73 \mathrm{E}-06$ & 0.623 & 0.219 \\
Liver & 0.412 & 1.304 & 0.768 & 0.961 & 1.889 & $2.00 \mathrm{E}-06$ & 0.815 & 0.238 \\
Thyroid & 0.579 & 1.722 & 1.072 & 1.340 & 3.334 & $3.37 \mathrm{E}-06$ & 0.901 & 0.356 \\
Esophagus & 0.247 & 0.794 & 0.381 & 0.481 & 1.239 & $6.30 \mathrm{E}-07$ & 0.358 & 0.126 \\
Skin & 0.422 & 1.303 & 0.750 & 0.945 & 2.244 & $2.36 \mathrm{E}-06$ & 0.704 & 0.228 \\
Other & 0.287 & 0.869 & 0.447 & 0.579 & 1.373 & $7.99 \mathrm{E}-07$ & 0.430 & 0.156 \\
Breast & 1.502 & 4.579 & 3.082 & 3.876 & 9.029 & $1.24 \mathrm{E}-05$ & 2.542 & 0.930 \\
\hline Total & 8.287 & 25.513 & 14.062 & 17.727 & 42.986 & $3.64 \mathrm{E}-05$ & 13.070 & 4.324 \\
\hline
\end{tabular}


Table M.23 Absorbed Dose to Organs for a Postmenopausal Adipose Female Healthcare Provider from Adipose Male Patient for Internal Contamination $(\mu \mathrm{Gy} / \mathrm{hr}) / \mathrm{ALI}$

\begin{tabular}{|c|cccccccc|}
\hline Organ & ${ }^{\mathbf{6 0}} \mathbf{C o}(\mathbf{s})$ & ${ }^{\mathbf{6 0}} \mathbf{C o}(\mathbf{m})$ & ${ }^{\mathbf{1 9 2}^{\mathbf{I r}}(\mathbf{s})}$ & ${ }^{\mathbf{1 9 2} \mathbf{I r}(\mathbf{m})}$ & ${ }^{\mathbf{1 9 2}^{\mathbf{I r}}(\mathbf{f})}$ & ${ }^{\mathbf{2 4 1}} \mathbf{A m}$ & ${ }^{{ }^{137}} \mathbf{C s}$ & ${ }^{\mathbf{1 3 1}_{\mathbf{I}}}$ \\
\hline \hline Gonads & 0.469 & 1.516 & 0.602 & 0.774 & 2.279 & $7.01 \mathrm{E}-07$ & 0.673 & 0.219 \\
Stomach & 0.825 & 2.466 & 1.351 & 1.732 & 5.365 & $2.67 \mathrm{E}-06$ & 1.343 & 0.440 \\
Colon Wall & 0.778 & 2.471 & 1.149 & 1.455 & 4.115 & $1.43 \mathrm{E}-06$ & 1.236 & 0.386 \\
Bladder & 1.496 & 4.700 & 2.210 & 2.811 & 7.749 & $2.85 \mathrm{E}-06$ & 2.199 & 0.684 \\
Lungs & 0.275 & 0.853 & 0.452 & 0.572 & 1.540 & $9.15 \mathrm{E}-07$ & 0.439 & 0.154 \\
Bone & 0.338 & 1.057 & 0.618 & 0.783 & 2.102 & $1.90 \mathrm{E}-06$ & 0.546 & 0.198 \\
Liver & 0.369 & 1.171 & 0.653 & 0.821 & 1.909 & $1.43 \mathrm{E}-06$ & 0.582 & 0.207 \\
Thyroid & 0.492 & 1.504 & 0.841 & 1.044 & 3.182 & $1.97 \mathrm{E}-06$ & 0.839 & 0.313 \\
Esophagus & 0.201 & 0.618 & 0.316 & 0.401 & 1.112 & $3.89 \mathrm{E}-07$ & 0.323 & 0.105 \\
Skin & 0.367 & 1.146 & 0.622 & 0.789 & 2.169 & $1.64 \mathrm{E}-06$ & 0.604 & 0.201 \\
Other & 0.251 & 0.793 & 0.375 & 0.486 & 1.354 & $5.33 \mathrm{E}-07$ & 0.381 & 0.247 \\
Breast & 1.274 & 3.950 & 2.480 & 3.142 & 8.492 & $7.95 \mathrm{E}-06$ & 2.179 & 0.792 \\
\hline Total & 7.136 & 22.245 & 11.670 & 14.809 & 41.368 & $2.44 \mathrm{E}-05$ & 11.345 & 3.945 \\
\hline
\end{tabular}

Table M.24 Absorbed Dose to Organs for a Postmenopausal Adipose Female Healthcare Provider from Adipose Female Patient for Internal Contamination $(\mu \mathrm{Gy} / \mathrm{hr}) / \mathrm{ALI}$

\begin{tabular}{|c|cccccccc|}
\hline Organ & ${ }^{\mathbf{6 0}} \mathbf{C o}(\mathbf{s})$ & ${ }^{\mathbf{6}} \mathbf{C o}(\mathbf{m})$ & ${ }^{\mathbf{1 9 2}} \mathbf{I r}(\mathbf{s})$ & ${ }^{\mathbf{1 9 2}} \mathbf{I r}(\mathbf{m})$ & ${ }^{\mathbf{1 9 2}} \mathbf{I r}(\mathbf{f})$ & ${ }^{\mathbf{2 4 1}} \mathbf{A m}$ & ${ }^{\mathbf{1 3 7}} \mathbf{C s}$ & ${ }^{\mathbf{1 3 1}} \mathbf{I}$ \\
\hline \hline Gonads & 0.512 & 1.627 & 0.696 & 0.863 & 2.923 & $7.73 \mathrm{E}-07$ & 0.746 & 0.235 \\
Stomach & 0.921 & 2.759 & 1.540 & 1.969 & 5.739 & $3.42 \mathrm{E}-06$ & 1.465 & 0.499 \\
Colon Wall & 0.845 & 2.637 & 1.251 & 1.580 & 5.376 & $1.66 \mathrm{E}-06$ & 1.268 & 0.413 \\
Bladder & 1.633 & 5.110 & 2.410 & 3.047 & 10.251 & $3.10 \mathrm{E}-06$ & 2.363 & 0.736 \\
Lungs & 0.296 & 0.918 & 0.505 & 0.640 & 2.009 & $1.14 \mathrm{E}-06$ & 0.461 & 0.168 \\
Bone & 0.356 & 1.112 & 0.656 & 0.830 & 2.635 & $2.17 \mathrm{E}-06$ & 0.559 & 0.209 \\
Liver & 0.393 & 1.243 & 0.717 & 0.901 & 3.067 & $1.69 \mathrm{E}-06$ & 0.600 & 0.225 \\
Thyroid & 0.504 & 1.565 & 0.869 & 1.084 & 3.346 & $2.33 \mathrm{E}-06$ & 0.832 & 0.326 \\
Esophagus & 0.231 & 0.722 & 0.322 & 0.408 & 1.271 & $5.65 \mathrm{E}-07$ & 0.320 & 0.114 \\
Skin & 0.395 & 1.229 & 0.689 & 0.872 & 2.850 & $1.99 \mathrm{E}-06$ & 0.629 & 0.218 \\
Other & 0.284 & 0.869 & 0.425 & 0.545 & 1.758 & $6.87 \mathrm{E}-07$ & 0.400 & 0.150 \\
Breast & 1.363 & 4.213 & 2.751 & 3.487 & 3.487 & $9.65 \mathrm{E}-06$ & 2.272 & 0.865 \\
\hline Total & 7.732 & 24.004 & 12.833 & 16.225 & 44.713 & $2.92 \mathrm{E}-05$ & 11.915 & 4.156 \\
\hline
\end{tabular}


Table M.25 Absorbed Dose to Organs for a Postmenopausal Adipose Female Healthcare Provider from Postmenopausal Adipose Female Patient for Internal Contamination ( $\mu \mathrm{Gy} / \mathrm{hr}) / \mathrm{ALI}$

\begin{tabular}{|c|cccccccc|}
\hline Organ & ${ }^{\mathbf{6}} \mathbf{C o}(\mathbf{s})$ & ${ }^{\mathbf{6 0}} \mathbf{C o}(\mathbf{m})$ & ${ }^{\mathbf{1 9 2}} \mathbf{I r}(\mathbf{s})$ & ${ }^{\mathbf{1 9 2}} \mathbf{I r}(\mathbf{m})$ & ${ }^{\mathbf{1 9 2}_{\mathbf{I r}}(\mathbf{f})}$ & ${ }^{\mathbf{2 4 1}} \mathbf{A m}$ & ${ }^{\mathbf{1 3 7}} \mathbf{C s}$ & ${ }^{\mathbf{1 3 1}} \mathbf{I}$ \\
\hline \hline Gonads & 0.506 & 1.573 & 0.679 & 0.867 & 2.085 & $6.24 \mathrm{E}-07$ & 1.214 & 0.205 \\
Stomach & 0.873 & 2.633 & 1.448 & 1.846 & 5.522 & $3.00 \mathrm{E}-06$ & 2.162 & 0.473 \\
Colon Wall & 0.817 & 2.566 & 1.189 & 1.502 & 4.176 & $1.54 \mathrm{E}-06$ & 2.071 & 0.391 \\
Bladder & 1.559 & 4.887 & 2.314 & 2.909 & 7.323 & $3.04 \mathrm{E}-06$ & 3.726 & 0.698 \\
Lungs & 0.287 & 0.890 & 0.473 & 0.599 & 1.564 & $9.78 \mathrm{E}-07$ & 0.703 & 0.157 \\
Bone & 0.347 & 1.080 & 0.633 & 0.802 & 2.096 & $1.96 \mathrm{E}-06$ & 0.859 & 0.201 \\
Liver & 0.380 & 1.202 & 0.680 & 0.852 & 1.869 & $1.50 \mathrm{E}-06$ & 0.896 & 0.211 \\
Thyroid & 0.481 & 1.488 & 0.831 & 1.053 & 3.003 & $2.20 \mathrm{E}-06$ & 1.270 & 0.306 \\
Esophagus & 0.218 & 0.693 & 0.324 & 0.406 & 1.182 & $4.25 \mathrm{E}-07$ & 0.516 & 0.107 \\
Skin & 0.382 & 1.187 & 0.657 & 0.831 & 2.172 & $1.78 \mathrm{E}-06$ & 0.945 & 0.208 \\
Other & 0.259 & 0.792 & 0.379 & 0.488 & 1.340 & $5.74 \mathrm{E}-07$ & 0.617 & 0.128 \\
Breast & 1.327 & 4.090 & 2.615 & 3.314 & 8.508 & $8.63 \mathrm{E}-06$ & 3.247 & 0.818 \\
\hline Total & 7.436 & 23.080 & 12.223 & 15.469 & 40.840 & $2.63 \mathrm{E}-05$ & 18.227 & 3.904 \\
\hline
\end{tabular}




\section{REFERENCES}

1. Bridges, A.H., Estimating the Radiation Dose to Emergency Room Personnel in an Event of a Radiological Dispersal Device Explosion. Georgia Institute of Technology, August 2005.

2. International Commission on Radiological Protection (ICRP). (1975). Report of the Task Group on Reference Male. ICRP Publication 23.

3. International Commission on Radiological Protection (ICRP). (1991). Recommendations of the ICRP. ICRP Publication 60. Annals of the ICRP, Volume 21, No. 1-3.

4. J.E. Martin and Chul Lee, Principles of Radiological Health and Safety. John Wiley Sons, Inc. Hoboken, New Jersey 2003 pg 286-291.

5. National Council on Radiation Protection and Measurements (NCRP). (1993). Limitation of Exposure to Ionizing Radiation. Report No. 116.

6. N. E. Hertel, R. W. Simpkins, Neutron Organ Dose and the Influence of Adipose Tissue.

7. R.J. Traub, P.C. Olsen, and J.C. McDonald "The Radiological Properties of a Novel Lung Tissue Substitute" Radiation Protection Dosimetry Volume 121 No 22006 pg 203 Oxford University Press, Oxford, UK.

8. Smith, J., Ansari, A., Harper, F., Hospital management of Mass Radiological casualties: Reassessing Exposures from Contaminated Victims of an Exploded Radiological Dispersal Device. Health Physics Journal Volume 89 Number 5, November 2005.

9. Stainless Steel - Grade304. On-line. Available from Internet, http://www.azom.com/details.asp?ArticleID=965, accessed 1 October 2007.

10. U.S. Nuclear Regulatory Commission. 2007. Annual Limit on Intake (ALI). On-line. Available from Internet, http://www.nrc.gov/reading-rm/basic-ref/glossary/annual-limit-onintake-ali.html, accessed 9 December 2007.

11. X-5 Monte Carlo Team. (2003). MCNP - A General Monte Carlo N-Particle Transport Code, Version 5. LA-UR-03-1987.

12. K. F. Eckerman, R. W. Leggett, M. Cristy, C. B. Nelson, J. C. Ryman, A. L. Sjoreen, and R. C. Ward. User's Guide to the DCAL System. ORNL/TM-2001/190, Oak Ridge National Laboratory. 2006.

13. Eckerman, K.F. and A.L. Sjoreen, Radiological Toolbox User's Manual. ORNL/TM2004/27, Oak Ridge National Laboratory. 2003. 
14. Tanner, J.E. Current Dose Studies on Effective Neutron Dose Equivalent. Eleventh DOE Workshop on Personnel Neutron Dosimetry. Las Vegas, Nevada: June 3-7, 1991. pg 173191.

15. Mathematica Version 6. Wolfram Research, Inc., 2007.

16. Code of Federal Regulations. Volume 10 Part 20 Subpart C. U.S. Government Printing Office, Washington: 1998. pg 291.

17. Loevinger, R. and M. Berman. NM/MIRD Phaphlet No 1, Revised. Society of Nuclear Medicine. New York, 1976.

18. Hatice Akkurt, Keith F. Eckerman. Development of PIMAL: Mathematical Phantom with Moving Arms and Legs. ORNL/TM-2007/14, Oak Ridge National Laboratory. 2007.

19. Amirsheybani, H.R. et al. The Natural History of the Growth of the Hand: I. Hand Area as a Percentage of Body Surface Area. http://www.ncbi.nlm.nih.gov/pubmed/11304598. 2001.

20. International Commission on Radiological Protection (ICRP). (1996). Age-dependent Doses to the Members of the Public from Intake of Radionuclides Part 5, Compilation of Ingestion and Inhalation Coefficients. ICRP Publication 72. Annuals of the ICRP, Volume 26/1. 